\title{
Synthesis of Juvenile Salmonid Passage Studies at The Dalles Dam Volume II: 2001-2005
}

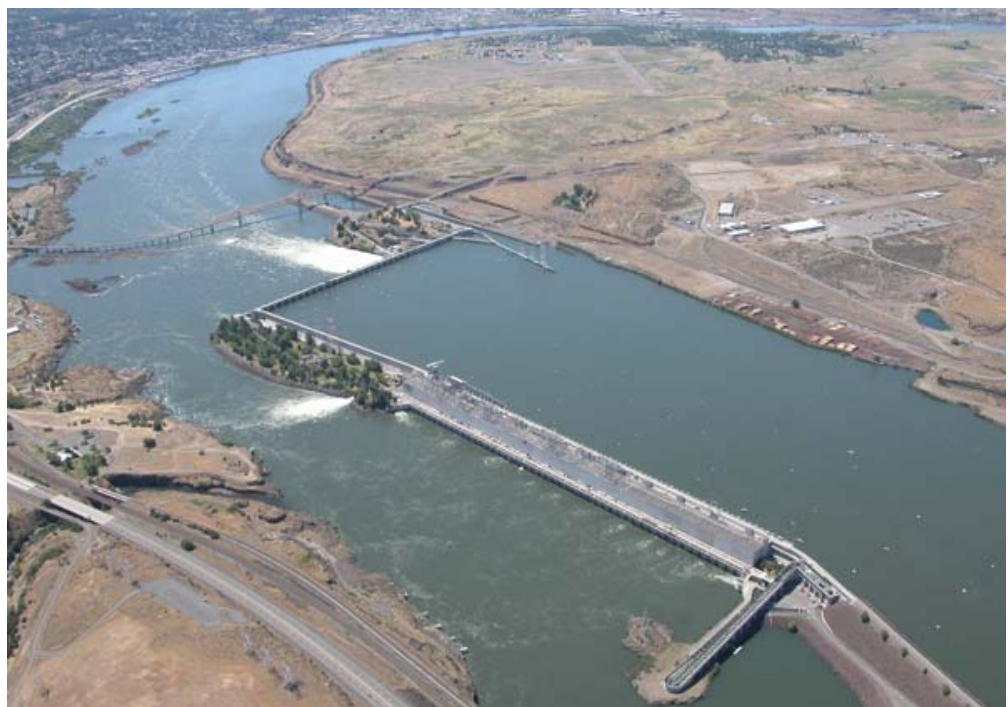

G.E. Johnson

J.W. Beeman

I.N. Duran

A.L. Puls

FINAL REPORT

August 2007

Prepared by:

Pacific Northwest National Laboratory and U.S. Geological Survey

Prepared for:

U.S. Army Corps of Engineers

Portland District, Portland, Oregon

under a Related Services Agreement with the U.S. Department of Energy

Contract DE-AC05-76RL01830

Pacific Northwest

National Laboratory

Operated by Battelle for the

U.S. Department of Energy

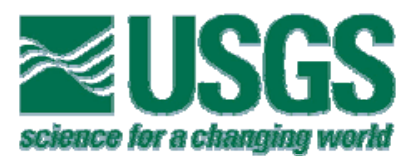




\section{DISCLAIMER}

This report was prepared as an account of work sponsored by an agency of the United States Government. Neither the United States Government nor any agency thereof, nor Battelle Memorial Institute, nor any of their employees, makes any warranty, express or implied, or assumes any legal liability or responsibility for the accuracy, completeness, or usefulness of any information, apparatus, product, or process disclosed, or represents that its use would not infringe privately owned rights. Reference herein to any specific commercial product, process, or service by trade name, trademark, manufacturer, or otherwise does not necessarily constitute or imply its endorsement, recommendation, or favoring by the United States Government or any agency thereof, or Battelle Memorial Institute. The views and opinions of authors expressed herein do not necessarily state or reflect those of the United States Government or any agency thereof.

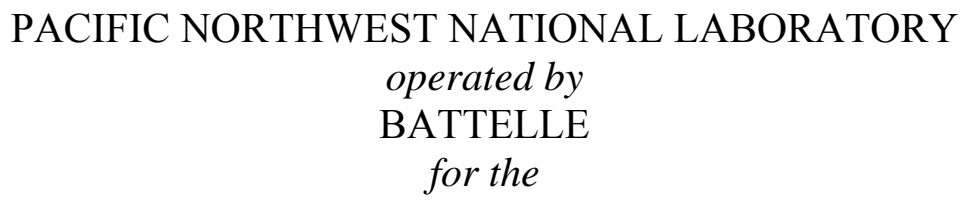

\section{UNITED STATES DEPARTMENT OF ENERGY}

under Contract: DE-AC06-75RLO1830

Printed in the United States of America

Available to DOE and DOE contractors from the

Office of Scientific and Technical Information, P.O. Box 62, Oak Ridge, TN 37831-0062;

ph: (865) 576-8401

fax: (865) 576-5728

email: reports@adonis.osti.gov

Available to the public from the National Technical Information Service, U.S. Department of Commerce, 5285 Port Royal Rd., Springfield, VA 22161

ph: (800) 553-6847

fax: (703) 605-6900

email: orders@ntis.fedworld.gov

online ordering: http://www.ntis.gov/ordering.htm 


\section{Synthesis of Juvenile Salmonid Passage Studies at The Dalles Dam Volume II: 2001-2005}

G. E. Johnson ${ }^{(a)}$

J. W. Beeman ${ }^{(b)}$

I. N. Duran ${ }^{(b)}$

A. L. Puls ${ }^{(b)}$

FINAL REPORT

August 2007

Prepared by:

Pacific Northwest National Laboratory ${ }^{(a)}$ and U.S. Geological Survey ${ }^{(b)}$

Prepared for:

U.S. Army Corps of Engineers

Portland District, Portland, Oregon

under a Related Services Agreement with

the U.S. Department of Energy

Contract DE-AC05-76RL01830 



\section{Preface}

This report synthesizes reports of research conducted on fish passage at The Dalles Dam between 2001 and 2005 under the auspices of the U.S. Army Corps of Engineers, Northwestern Division's Anadromous Fish Evaluation Program (AFEP) to implement the congressionally appropriated Columbia River Fish Mitigation Project. The work pertains to AFEP study codes SBE-P-00-017 and SPY-P-00-08. This study was funded by the Portland District, U.S. Army Corps of Engineers (USACE) under contracts with 1) the Pacific Northwest National Laboratory (PNNL), operated by Battelle for the U.S. Department of Energy, and 2) the U.S. Geological Survey (USGS), Western Fisheries Research Center, Columbia River Research Laboratory.

Drafts of this report were made available for regional peer-review. The suggestions and comments we received have been incorporated as appropriate into the final report. Of particular note, Dr. Cliff Pereira provided comments on the hierarchical regression in the draft final report that Dr. John Skalski responded to by revising the analysis write-up, now included in the report as Appendix D.

This 2001-2005 report is the second volume in a series of synthesis reports on fish passage at The Dalles Dam. Volume I, Synthesis of Juvenile Salmonid Passage Studies at The Dalles Dam, Volume I: 1982-2000, was provided by Ploskey et al. (2001a). A compact disc containing PDFs of available reports that were referenced in this synthesis is provided with the paper version of this report. The CD also contains PDFs of this report and Volume I. Fish passage research in 2006 and beyond may be synthesized as appropriate in future volumes in the series.

\section{Executive Summary}

The overall goal of juvenile salmonid research at The Dalles Dam is to provide data to inform decisions on strategies to improve smolt survival rates at the project. Survival improvement strategies address the three primary passage routes at The Dalles Dam -- spillway, sluiceway, and turbines - with the general intent to increase spill and sluice passage and decrease turbine passage. From 2001, when Ploskey et al. (2001a) completed their review of 1982-2000 research, through 2005, the USACE has funded over $\$ 20 \mathrm{M}$ of research in at least 40 studies. The purpose of this current review is to synthesize juvenile salmonid passage data at The Dalles Dam (TDA) collected from 2001 through 2005.

The data we synthesized were gathered using numerous research techniques employed to address various study objectives at The Dalles Dam. The suite of techniques included acoustic and radio telemetry, acoustic cameras, acoustic Doppler current profilers, balloon tags, computational fluid dynamics models, drogues, fixed and mobile hydroacoustics, fyke nets, physical scale models, PIT-tags, Sensor Fish, sonar trackers, and underwater video. Hydraulic data involved flow patterns and water velocities. Biological data concerned forebay approach paths and residence times, horizontal and diel distributions, passage efficiencies and effectiveness, fish behaviors, tailrace egress and predation rates, and route-specific and total project survival rates. Data for 2001-2005 are synthesized in this report to provide, in conjunction with Ploskey et al. (2001a), resources for engineers, biologists, and dam operators to use when making decisions about fish protection measures for juvenile salmonids at The Dalles Dam. 
This review document covers the major fish passage research efforts during 2001-2005 and includes sections on the environmental and biological setting, forebay and project passage studies, spill studies, sluiceway studies, turbine studies, smolt survival studies, and a discussion.

\section{Environmental and Biological Setting}

The Dalles Dam plays a key role in the Bonneville Power Administration's (BPA) transmission system because it is at the northern terminus of the 2,100 megawatt (MW) direct current intertie to Los Angeles and three major alternating current lines. The dam provides critical voltage support to the transmission system that helps avert power outages. As a run-of-river project with a forebay elevation operating range of only $5 \mathrm{ft}$, the dam is not designed to store water for the purpose of power peaking. The project, however, is operated as part of a system of hydroelectric generating stations that provide electricity during peak demand periods. As such, total project discharge can vary by as much as $100 \mathrm{kcfs}$ within a given day.

The Dalles Dam has a reverse L-configuration with the 22-unit, 1,780-MW, 270- thousand cubic feet per second (kcfs) powerhouse parallel to river flow and a 23-bay, radial gate spillway perpendicular to flow. The powerhouse contains a sluiceway that discharges about $4.5 \mathrm{kcfs}$ of surface water. A $193-\mathrm{ft}-$ long spillwall between Bays 6 and 7 in the stilling basin was installed in 2003/2004 to channel spill discharge into the thalweg downstream of the dam for the purpose of juvenile fish protection. The forebay is relatively shallow ( $<65 \mathrm{ft}$ deep), except for several deep areas upstream of the powerhouse, such as Big Eddy, which is a very deep area in the forebay off the east end of the powerhouse.

Bathymetry downstream of the dam is characterized by extremely deep thalweg areas ( $>200 \mathrm{ft}$ deep), a shallow stilling basin for the spillway, islands, and shallow rocky areas. Forebay flow stream lines have two major paths when the spillway is open, one to the powerhouse and one to the spillway.

Monthly total river discharge during the primary juvenile fish passage period (April through August) in 2001-2005, expressed as the mean daily discharge, was highest in June 2003 at $317 \mathrm{kcfs}$ and lowest in July 2001 at $86 \mathrm{kcfs}$. The 2001 study-year had especially low flows, about $46 \%$ of the 10 -year average. Voluntary spill for juvenile fish protection at $40 \%$ of total river discharge typically occurs from April 10 to August 31. This spill is bulked in Bays 1-6 (since the 2004 season), unless spill discharge exceeds about $120 \mathrm{kcfs}$, then additional bays are opened as necessary. During 2001-2005, daily spill ranged from 0 to about $200 \mathrm{kcfs}$.

The following juvenile salmonids migrate downstream past The Dalles Dam: Oncorhynchus tshawytscha Chinook salmon (yearling and sub-yearling), O. mykiss steelhead trout, O. nerka sockeye salmon (yearling), and O. kisutch coho salmon (yearling). During April through August 2001-2005, species composition at The Dalles Dam, based on monitoring data from John Day Dam, was 50\% subyearling Chinook salmon, 30\% yearling Chinook salmon, $8 \%$ steelhead, $8 \%$ sockeye salmon, and $4 \%$ coho salmon. These percentages do not include approximately 1 million hatchery yearling Chinook salmon released annually into the Deschutes River, a tributary of the Columbia River below John Day Dam and above The Dalles Dam. The yearling and subyearling Chinook salmon are the most common juvenile salmonids migrating through The Dalles Dam. 


\section{Forebay and Project Passage Studies}

The forebay and project passage studies during 2001-2005 examined migration pathways, residence times, distributions, and passage efficiencies. Forebay approach and movement data from acoustic- and radio-telemetry studies with multiple tagged species showed a general pattern. Fish tended to migrate downstream with the bulk flow in the thalweg and took one of two primary pathways once they exited the region of Big Eddy upstream of the dam. One path headed directly to the spillway and the other path headed toward the powerhouse. Some of the fish taking the powerhouse pathway moved along the powerhouse and finally passed at the spillway. Forebay movement patterns were driven by spilling $40 \%$ of total project discharge.

Residence times in The Dalles Dam forebay, defined as the duration between the time of first detection on dam-mounted, 330-ft-range aerial antennas and the time of last detection on underwater antennas at dam portals, were generally less than $0.6 \mathrm{~h}$ (median), though under some conditions in 2001 forebay residence times of juvenile steelhead were up to $10 \mathrm{~h}$. There were small differences among residence times for fish passing the turbines, sluiceway, and spillway. Overall residence times were shorter during the day than at night.

Passage efficiency and effectiveness for subyearling and yearling Chinook salmon and steelhead in the years 2002-2005 from radio-telemetry data expressed as means of the yearly values were as follows. We did not include data from 2001 because there were substantial periods without spill during this drought year.

\begin{tabular}{cccccc}
\hline & \multicolumn{2}{c}{ Efficiency (\%) } & \multicolumn{2}{c}{ Effectiveness } \\
& Sluiceway & Spillway & FPE & Sluiceway & Spillway \\
\hline CH 0 & 7.6 & 72.7 & 80.2 & 3.2 & 1.9 \\
CH 1 & 11.8 & 73.1 & 84.9 & 4.7 & 2.0 \\
STH & 14.0 & 76.0 & 90.0 & 9.3 & 2.0 \\
\hline
\end{tabular}

The horizontal distribution of fish passage for the run at large at the powerhouse was skewed toward the western end of the structure during spring. However, during summer, the horizontal distribution was more uniform across the powerhouse with passage rates at eastern units higher during summer than spring. At the spillway, the horizontal distribution during spring was skewed to the southern-most operating bays. During summer at the spillway, passage rates by bay were variable. Normalizing the turbine horizontal distribution data by turbine discharge (fish density = passage per unit flow) showed that the eastern units had the highest fish densities during summer. Fish densities at the turbines were variable in spring.

The vertical distribution for the run at large from hydroacoustic sampling inside turbine intakes showed the typical concentration near the intake ceiling. Turbine passage was somewhat deeper during night than day. Spillway vertical distribution, which is typically deeper during summer than spring, was variable with peaks toward the surface or the ogee.

Diel distribution data showed the typical crepuscular peak at dusk for turbine passage. Spillway and sluiceway passage tended to be higher during day than night hours, although diel passage patterns were variable among and within study years.

Forebay hydraulic research was conducted for the purpose of specific fisheries engineering efforts, such as a Behavioral Guidance Structure in the forebay. Engineers and biologists used 1:80 and 1:25 
scale physical models and computational fluid dynamics models, along with field investigations with acoustic Doppler current profilers, to characterize hydraulic conditions. Forebay current patterns have two prevalent flow regimes, one toward the powerhouse and one toward the spillway. Forebay current patterns were affected by total river discharge and project operations.

\section{Spillway Studies}

The spillway studies at The Dalles Dam during 2001-2005 addressed spill operations, spillway structures, such as the Bay 6/7 spillwall in the stilling basin, tailrace egress and predation, and mechanisms of fish injury and mortality at the spillway.

A relationship between spillway passage efficiency and either spill rate $(\mathrm{kcfs})$ or proportion was not evident from hydroacoustic data combined over the study years or from daily radio-telemetry data from 2005. For a given spill proportion (e.g., 0.40), daily spill passage efficiency was variable, ranging from 0.25 to 1 . However, a hierarchical multiple regression analysis of the relationship between spill passage efficiency (daily hydroacoustic data) and independent variables for environmental conditions (water temperature and Julian date) and spill operations (spill proportion and spill discharge) was conducted for hydroacoustic data from studies in 1999, 2000, 2001, 2002, and 2004. In hierarchical regression, nonflow-related parameters were incorporated into the model, followed by relevant flow parameters. The purpose was to see if spill proportion and discharge explained spill passage efficiency after certain ambient factors were considered. The analysis showed that water temperature and Julian date alone explained $56 \%$ of the variance in daily spill passage efficiency. Adding spill proportion to the model increased the percentage of explained variance, $\mathrm{R}^{2}$, to $61 \%$. Spill discharge was a statistically insignificant $(\mathrm{P}=0.82)$ variable in the regression model.

Horizontal distribution at the spillway during bulk spill in Bays 1-6 was skewed to Bays 5 and 6 . This result was consistent between radio telemetry and hydroacoustic studies. When spill discharge was greater than about $120 \mathrm{kcfs}$, Bays 7 and 8 and beyond were opened as necessary; noticeable numbers of juvenile salmonids passed in this discharge.

The 193-ft spillwall in the stilling basin between Bays 6 and 7 was installed in winter 2003/2004. A new spill pattern was developed to reduce fish passage in bays south of Bay 6 and to stop the lateral movement of water and fish across the stilling basin. Overall survival of fish passing via the spillway after construction of the spillwall was similar to pre-wall conditions.

Survival estimates from paired releases for radio-tagged fish averaged over the 2004 and 2005 studies showed that survival was higher at Bays 1-4 than at Bays 5-6 (see the following table). The cause of the lower survival in Bays 5-6 has not been definitively identified; one hypothesis is predation in the stilling basin and island areas along the edge of the spill discharge plume.

\begin{tabular}{ccc}
\hline & Bays 1-4 & Bays 5-6 \\
\hline CH 1 & 0.95 & 0.91 \\
CH 0 & 0.94 & 0.84 \\
\hline
\end{tabular}

Tailrace egress assessments using radio-tagged salmonids and drogues showed that travel times from the release point at the dam to an exit station $1.7 \mathrm{~km}$ downstream were generally shortest for fish released in the northern part of the spillway, moderate in the middle, and longest in the south. Also, fish passing the northern part of the spillway were less likely to egress through the island areas below the dam than fish passing in the south spillway. 
In balloon tag studies for fish released at the spillway, head injuries were most common. The most prevalent injury types were hemorrhages or ruptures of the eye, torn operculum, and scrapes and bruises. Overall rates of injury related to passage ranged from 0 to $11 \%$. The injuries to the eye and operculum were attributed to damage from shear forces. Scrapes and bruises to the head were attributed to mechanical contact with solid objects, such as the baffle blocks, the end sill, or rocks.

During balloon tag studies of direct survival, survival probabilities of Bay 6 fish were 0.959 (SE 0.038 ) at high tailwater elevation ( 80 to $83 \mathrm{ft}$ ) and 0.851 (SE 0.030 ) at low tailwater elevation (76 to 80 $\mathrm{ft}$ ). Survival probabilities of fish from Bays 2 and 4 were greater than 0.96 (SE 0.007 to 0.018 ) in all trials.

The primary piscivorous predator species in The Dalles Dam tailrace are northern pikeminnow (Ptychocheilus oregonensis) and smallmouth bass (Micropterus dolomieu). California gulls (Larus californicus) are also a common avian predator. Detections of radio-tagged predator fishes were highest along the shorelines of the river and islands throughout the tailrace. No radio telemetry studies of predator fish post-spillwall distributions have been conducted.

\section{Sluiceway Studies}

The sluiceway studies during 2001-2005 concerned sluice gate configurations and fish behavior at the sluiceway nearfield (within $30 \mathrm{ft}$ ). Maximum sluiceway discharge is $\sim 4,500$ cubic feet per second (cfs) and depends on forebay elevation and the number and location of open gates. The closer the gate is to the flow control point at the west end of the sluiceway channel, the higher the discharge for a given gate opening. Sluiceway discharge rating curves for 3-gate (1-1, 1-2, and 1-3) and 6-gate (1-1, 1-2, 1-3, 18-1, 18-2, and 18-3) operations are

3-gate: Sluiceway Q (cfs) $=-78803+517 *$ Forebay Elevation $(\mathrm{ft})$

6-gate: Sluiceway Q (cfs) $=-58178+395 *$ Forebay Elevation $(\mathrm{ft})$.

Flow approaches a sluice entrance at an oblique angle relative to the powerhouse, but becomes increasingly perpendicular within 5 to $15 \mathrm{ft}$ of the outlet. Flow into the sluiceway has a gradual acceleration until it goes over the sill, where water accelerates rapidly into the sluice channel. The computational fluid dynamics (CFD) modeling revealed that nearfield forebay velocities were generally less than $2 \mathrm{fps}$, except within $10 \mathrm{ft}$ of the sluiceway weir.

Different sluiceway gate configurations were evaluated in 2004 and 2005. Juvenile salmonids passed into the experimental east end sluice entrances in 2004 (SL 18) and 2005 (SL 19), but the majority (> $62 \%$ ) of fish passage into the sluiceway occurred in both spring and summer through the west gates in 2004 (SL 1) and in 2005 (SL 2) - this result was evident in both the hydroacoustic and radio telemetry studies. The hypothesized effect of east-end sluice gates on total sluiceway passage, especially for subyearling migrants in summer, was equivocal for the operations tested in 2004 and 2005 because of the relatively low inflow $(\sim 1,700 \mathrm{cfs})$ and corresponding small flow net for the sluice entrances at the east end of the dam. Opening west end gates is a must, but the optimum location for other open sluice gates remains a question as no single sluiceway operation stood out as the best in terms of efficiency relative to total powerhouse passage.

Fish behavior in the nearfield $(<30 \mathrm{ft})$ of the sluiceway is complex and variable. At Sluice 1 at the west end of the dam, the predominate movement directions were generally to the west toward the spillway and to the south toward the sluiceway. Juvenile salmonids are surface-oriented and will move upward in the water column to pass into the sluiceway. Some fish hold in front of the sluice sill, 
exhibiting positive rheotaxis by swimming into the flow. The zone of entrainment (defined as the distance from the sluiceway where the probability of moving toward the sluiceway was greater than 90\%) is approximately $20 \mathrm{ft}$. This zone was larger for spring than summer migrants and larger at west end than east end gates.

\section{Turbine Studies}

Turbine studies at The Dalles Dam were conducted to evaluate intake screens and occlusions. (We include studies prior to 2001 because this juvenile passage information is not reported in Volume I of the synthesis series.) We found that fish guidance efficiency (FGE) for yearling Chinook salmon was greater than $60 \%$ for the extended-length screens, but the best FGE observed for subyearling Chinook salmon was 54\%. Thus, the goal of $70 \%$ FGE was not met for subyearling Chinook salmon.

The most thorough study of the J-occlusion plates occurred in 2002. The results did not indicate a clear advantage of deploying intake occlusion plates for the purpose of smolt protection at The Dalles Dam. During spring 2002, the hydroacoustic and radio-telemetry data typically showed no significant differences between IN/OUT treatments for various response variables. During summer 2002, the hydroacoustic study showed negative effects in terms of Main Unit (MU) 1-4 turbine passage during day and night. On the other hand, the radio telemetry study demonstrated positive effects in terms of sluiceway efficiency during night. All other statistical comparisons were insignificant $(\mathrm{P}>0.05)$. The CFD data indicated that the water current patterns in the forebay were stronger downward toward the turbines with the J-occlusion plates IN than OUT. Block loading MU 1-5 during the 2002 J-occlusion evaluation also affected forebay flow patterns and passage at the powerhouse and spillway by creating a strong current toward the west end of the powerhouse.

\section{Survival Studies}

Results from the survival studies at The Dalles Dam during 2001-2005 may be summarized as follows. To synthesize the survival estimates, we averaged data from radio telemetry studies in 2002, 2004, and 2005 The data from 2004 do not include that from July 22-29 when water temperatures exceeded $21 \mathrm{deg} \mathrm{C}$, as this time period was not present in the other studies. Estimates were generated using the route-specific survival model and radio-tagged fish released by boat in the tailraces of John Day Dam (treatment) and The Dalles Dam (control).

\begin{tabular}{ccccccc}
\hline & Project & Pool & Dam & Turbines & Sluiceway & Spillway \\
\hline CH 1 & 0.829 & 0.916 & 0.904 & 0.828 & 0.966 & 0.910 \\
CH 0 & 0.801 & 0.907 & 0.883 & 0.781 & 0.858 & 0.916 \\
\hline
\end{tabular}

Route-specific survival for yearling Chinook salmon was highest at the sluiceway (97\%) and lowest at the turbines $(83 \%)$. Route-specific survival for subyearling Chinook salmon was highest at the spillway (92\%) and lowest at the turbines (78\%). Dam and pool survivals were both about $90 \%$, producing a project survival of about $81 \%$. Results of survival estimates specifically through the sluiceway and spillway using other survival models are also presented in this report.

\section{Discussion}

Dam passage survival at The Dalles Dam remains a concern, especially for subyearling Chinook salmon. Increases in dam survival will be most likely if survivals through the spillway or turbines are improved or turbine entrainment is reduced. Survival through the sluiceway is generally high, and the mortality associated with this route appears to be related to the migration after exiting the sluiceway 
rather than passage through the route itself. Increasing dam passage through improvements in the sluiceway would be critical to improve dam passage survival if spill levels are reduced, or in years when spill may not be present (i.e., low flow years). Increasing the proportion of fish passing this route would provide some increase in dam survival during most conditions. Means to decrease turbine passage, such as a berm at the exit to Big Eddy, should also be considered. Inasmuch as spill will likely be a significant part of any method to increase dam passage survival, improvements to the spillway seem to have the greatest potential for improving dam passage survival providing we learn more about the mechanisms of mortality downstream of the spillway ogee.

In closing, for the project as a whole, we understand well many aspects of juvenile fish passage, including forebay approach and tailrace egress migration routes and travel rates; project and routespecific survival rates; fish passage efficiencies; vertical, horizontal, and diel distributions; and hydraulic conditions and current patterns in the forebay and tailrace. We are less certain about relationships between juvenile salmonid responses and hydrodynamic conditions, spill efficiency and spill operations, mechanisms of mortality and mortality rates downstream of the spillway ogee. Increased understanding of these relationships, especially those for subyearling Chinook salmon, will provide a basis for measures to increase juvenile salmonid survival in a cost-effective manner at The Dalles Dam. 


\section{Acknowledgments}

We earnestly acknowledge contributions to this study by the following people:

- $\quad$ Laurie Ebner, Mike Langeslay, and Bob Wertheimer (USACE) provided data, reports, and literature citations and reviewed the $60 \%$ and $90 \%$ draft reports.

- $\quad$ Laurie Ebner drafted descriptions and provided graphs of the hydraulic model work.

- Dick Harrison (USACE) and Scott Bettin (Bonneville Power Administration) explained the importance of The Dalles Dam to the Federal Columbia River Power System's transmission grid.

- John Skalski and Jim Griswold (University of Washington) performed the regression analyses of spill passage.

- Cliff Pereira (Oregon State University) provided peer-review comments on the hierarchical regression in Chapter 4.

- Laura Dingmon, Steve Juhnke, and Hal Hansel (USGS) compiled and organized the literature, created tables, and provided data from previous studies of radio-tagged fish.

- $\quad$ Fenton Khan (PNNL) helped gather reports.

- $\quad$ Gene Ploskey (PNNL) provided hydroacoustic data.

- $\quad$ Dick Ecker, Terri Gilbride, and Gene Ploskey (PNNL) and Dennis Rondorf (USGS) reviewed and edited the report. 


\section{Contents}

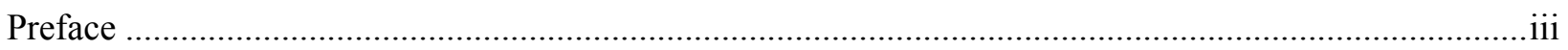

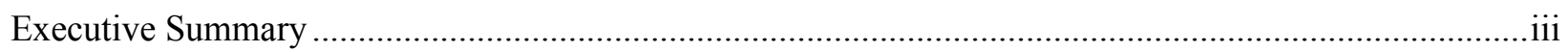

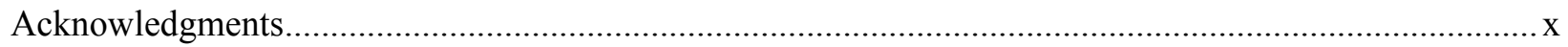

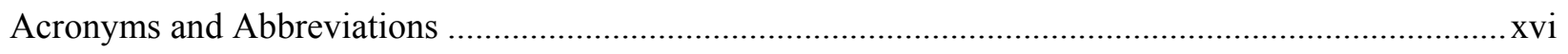

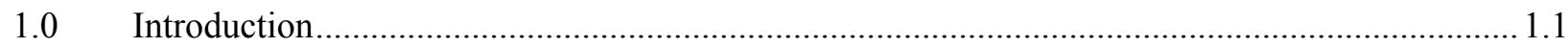

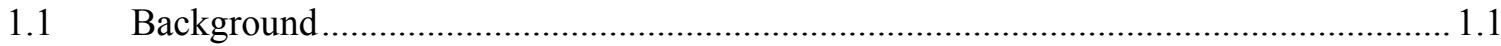

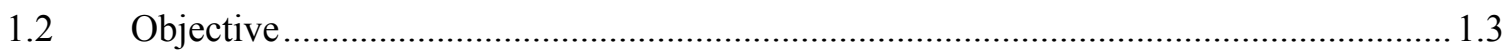

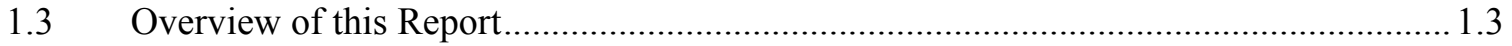

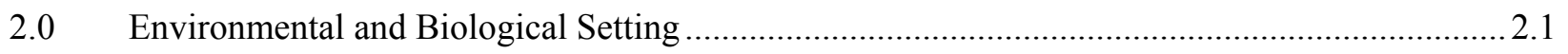

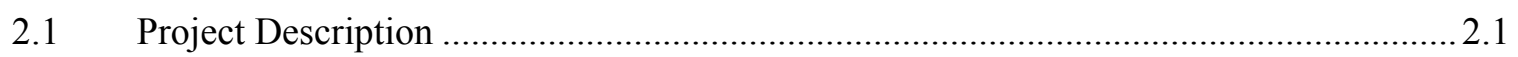

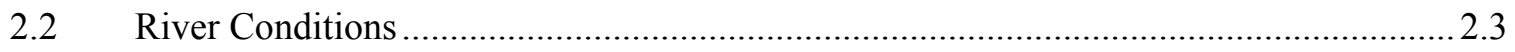

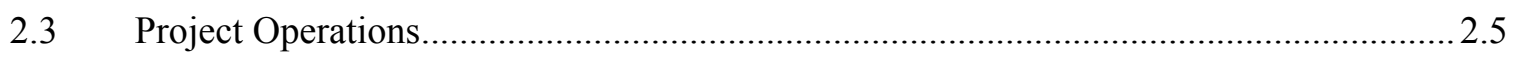

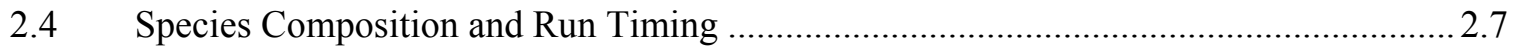

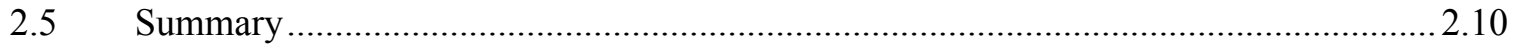

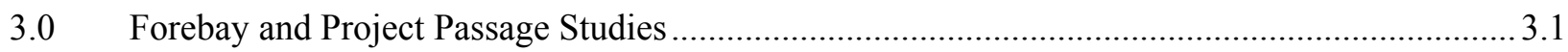

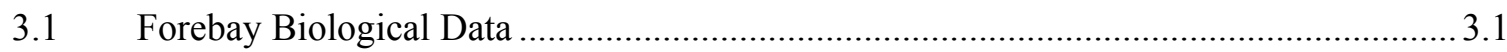

3.1.1 Approach Patterns................................................................................. 3.1

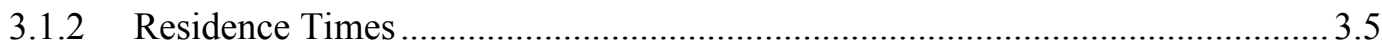

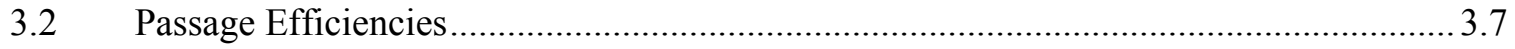

3.2.1 Passage Efficiency Estimates from Radio and Acoustic Telemetry .................... 3.8

3.2.2 Passage Efficiency Estimates for Hydroacoustics ............................................ 3.9

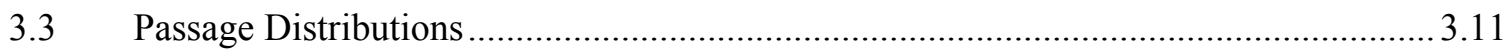

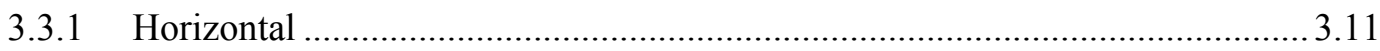

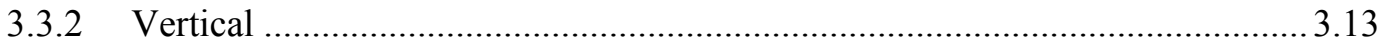

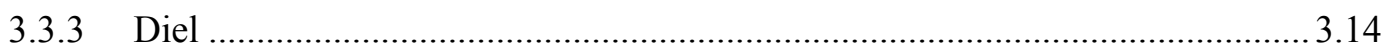

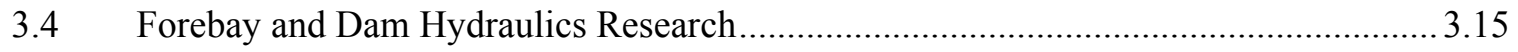

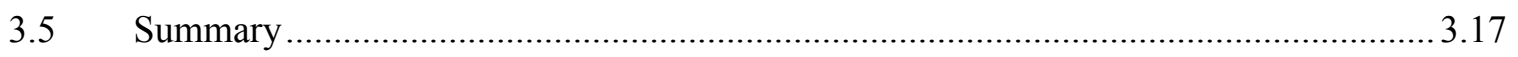

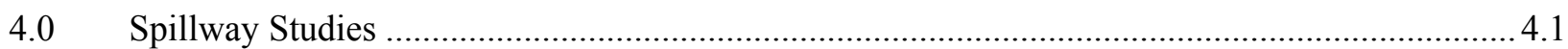

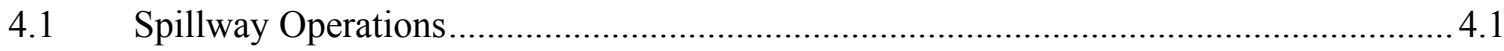

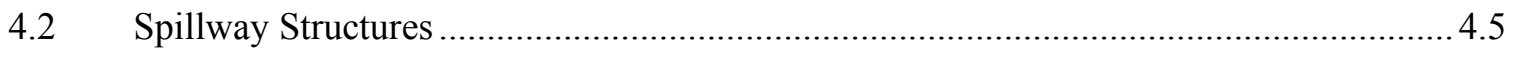

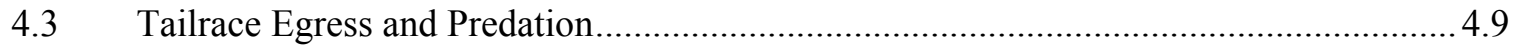

4.3.1 Tailrace Egress....................................................................................... 4.9

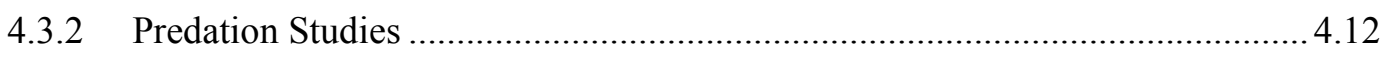

4.4 Mechanisms of Fish Injury and Mortality at the Spillway ........................................... 4.14

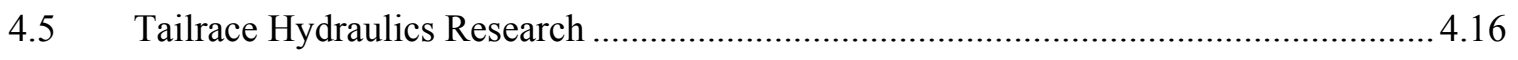

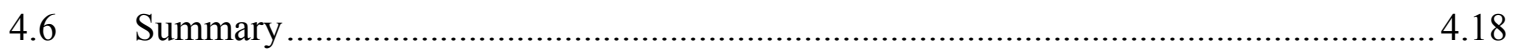

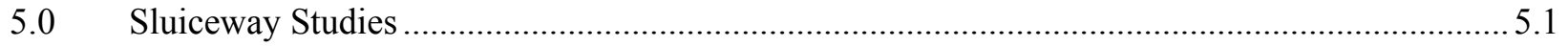




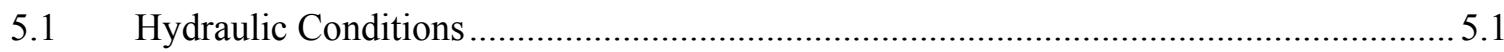

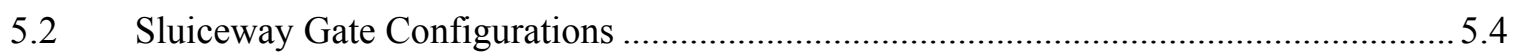

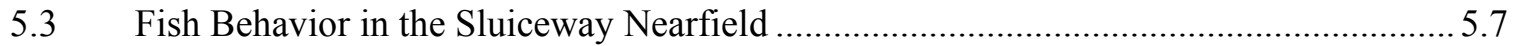

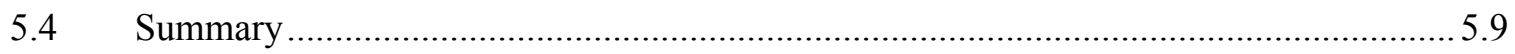

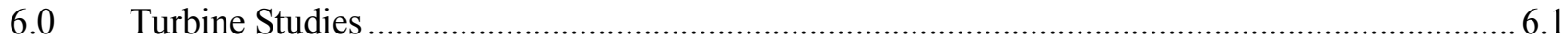

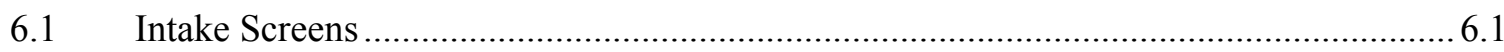

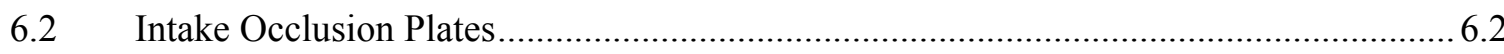

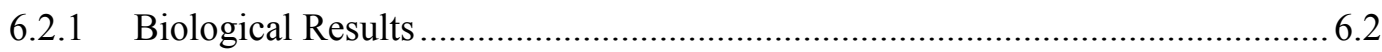

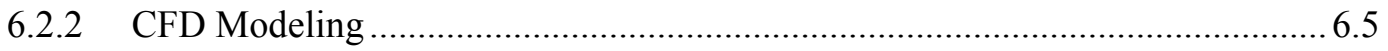

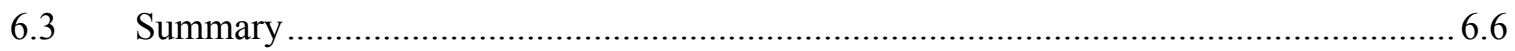

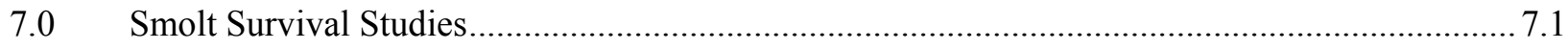

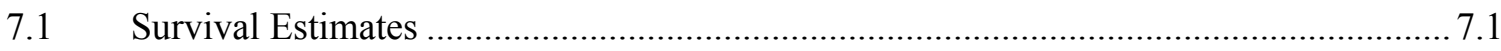

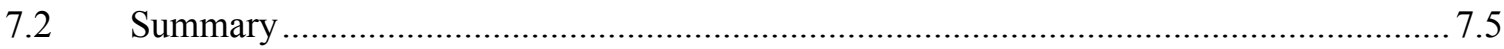

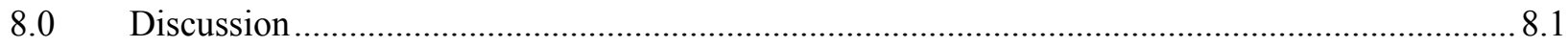

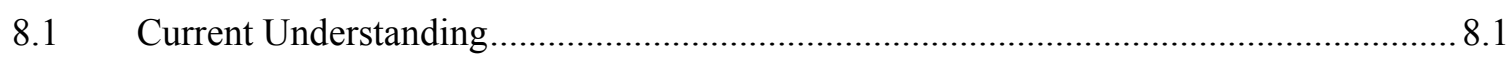

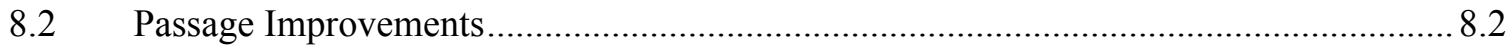

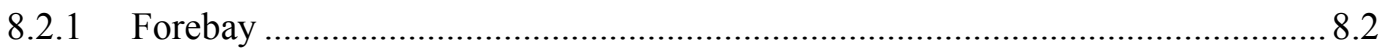

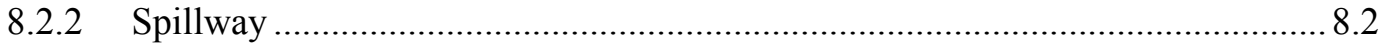

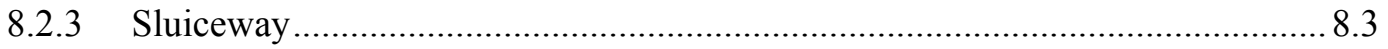

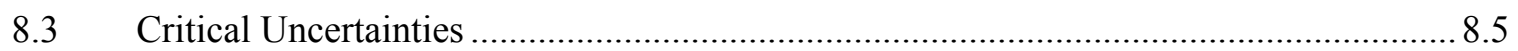

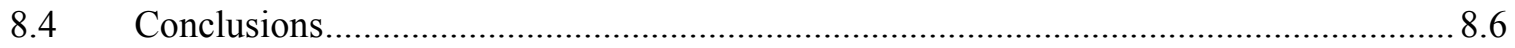

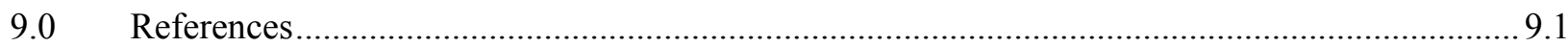

Appendix A - Technical Reports from Passage Studies at The Dalles Dam, 1982-2005 (full reports

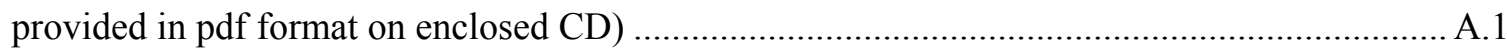

Appendix B - Forebay Approach and Residence Time Results.......................................................... B.1

Appendix C - Passage Efficiency and Effectiveness of Tagged Juvenile Salmonids at

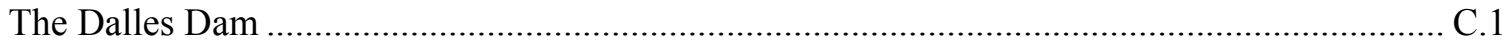

Appendix D - Regression Analysis of Spillbay Passage at The Dalles Dam........................................ D.1 


\section{Figures}

Figure 1.1. Aerial Photograph of The Dalles Dam ........................................................................ 1.1

Figure 2.1. Plan View of The Dalles Dam Showing Forebay Bathymetry ….......................................2.1

Figure 2.2. Perspective View of The Dalles Dam Showing Tailrace Bathymetry................................2.2

Figure 2.3. Plan View of The Dalles Dam Tailrace and Shoreline Showing Spillway, Sluiceway, and Powerhouse Outlets and Bridge and Basin Islands ....................................................... 2.3

Figure 2.4. River Discharge and Spill Percentage at The Dalles Dam, 2001-2005 ..............................2.4

Figure 2.5. Temperature at The Dalles Dam, 2001-2004 .................................................................2.5

Figure 2.6. Example of Load Following as Shown by the Diel Distribution of Turbine Discharge at The Dalles Dam during Spring and Summer 2005 .........................................2.6

Figure 2.7. Spill Discharge (kcfs) at The Dalles Dam, 2001-2005 …................................................... 2.6

Figure 2.8. Schematic of Spill Gate Openings of Juvenile and Adult Spill Patterns ..............................2.7

Figure 2.9. Run Timing for April 1 to August 31, 2001-2005 for Yearling Chinook, Coho, and Sockeye Salmon, Steelhead, and Subyearling Chinook Salmon ....................................2.9

Figure 3.1. Passage Proportions of Radio-Tagged Yearling Chinook Salmon during Spring 2004 ......... 3.2

Figure 3.2. Yearling Chinook Salmon Forebay Approach Locations at The Dalles Dam, April 28

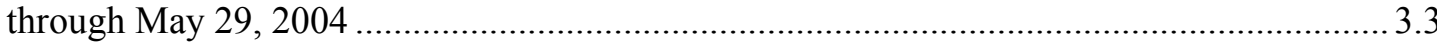

Figure 3.3. Horizontal Distributions of Acoustic-Tagged Yearling Chinook Salmon in the Forebay of The Dalles Dam

Figure 3.4. Plan Views of Volumetric Spillway Passage Efficiency of Hatchery Steelhead, Yearling Chinook Salmon, and Subyearling Chinook Salmon during 2004 at The Dalles Dam.

Figure 3.5. Kaplan-Meier Survivor Function Distributions of the Forebay Residence Time (h) of Radio-Tagged Yearling and Subyearling Chinook Salmon in 2005

Figure 3.6. Horizontal Distribution of Fish Passage Proportions at the Turbines and Spillway at The Dalles Dam during Spring and Summer 2001-2005, except 2003.

Figure 3.7. Horizontal Distribution of Fish Density Proportions at Turbines at The Dalles Dam during Spring and Summer 2002, 2004, and 2005

Figure 3.8. Vertical Distribution of Fish Passage Proportions at Turbines at The Dalles Dam during Spring and Summer 2004 and 2005

Figure 3.9. Vertical Distribution of Fish Passage Proportions at Spillway at The Dalles Dam during Spring and Summer 2004.

Figure 3.10. Diel Passage Distributions of Radio-Tagged Juvenile Chinook Salmon through the Main Routes at The Dalles Dam and Overall FPE during 2004

Figure 3.11. Diel Passage Distributions during Spring and Summer for Turbine, Sluice and Spill at The Dalles Dam 
Figure 3.12. Streamlines from a Forebay CFD Model.

Figure 4.1. Percent of Water Spilled through Spill Bays and the Percent of Volitionally Passing Radio-Tagged Yearling (left) and Subyearling (right) Chinook Salmon Detected Passing the Bays

Figure 4.2. Spill Passage Effectiveness by Spill Bay at The Dalles Dam in 2004

Figure 4.3. Within-Bay Horizontal Distribution of Acoustic-Tagged Juvenile Salmonids at The Dalles Dam, 2004. 4.3

Figure 4.4. Spill Passage Efficiency by Daily Estimates versus Spill Proportion and Spill Rate for Radio-Tagged Fish in 2005

Figure 4.5. Spill Passage Efficiency by Season versus Spill Proportion and Spill Discharge.

Figure 4.6. Representative Drogue Movement Paths following Releases at The Dalles Dam Spillway from May 5 to August 7, 2002

Figure 4.7. The Dalles Dam on June 12, 2004 Illustrating the Wall between Spill Bays 6 and 7 4.8

Figure 4.8. Locations of Radio-Tagged Predators in The Dalles Dam Tailrace, 2002

Figure 4.9. Scatter Plots of Distance from Shore and River Depth versus Water Velocity Associated with Locations of Radio-Tagged Northern Pikeminnow and Smallmouth Bass in The Dalles Dam Tailrace, 2002. 4.14

Figure 4.10. The Dalles Dam Spillway with Energy Dissipation Structures. 4.15

Figure 4.11. Simulated Drogue Travel Paths in the TDA Stilling Basin from CFD Model 4.17

Figure 5.1. Sluiceway Discharge Rating Curves.

Figure 5.2. Plan View of Water Velocity at Elevation $155 \mathrm{ft}$ at Sluice 2 ..... 5.2

Figure 5.3. Cross-Sectional View of Water Velocity at Two Sluice Entrances, 1-2 and 18-2 for the 6-Gate Configuration Described in Table 6.1.

Figure 5.4. Sluiceway Efficiency for Configurations Tested 1999-2005

Figure 5.5. Sluiceway Efficiency by Total River, Powerhouse, and Spillway Discharge and the Percentage of Sluiceway Out of Powerhouse Discharge for Configurations Tested 1999-2005

Figure 5.6. Three-Dimensional Presentation of the Sluice Fate for Selected Inner Slices of the Sample Volume

Figure 5.7. Fish Passage Probabilities at The Dalles Dam SL 2 and SL 19 in 2005 ............................5.8

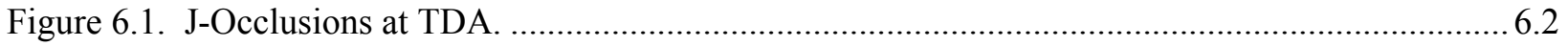

Figure 6.2. Sectional View of Water Velocity at the Centerlines of MU 1-2 and MU 4-2 with JOcclusions IN and OUT

Figure 6.3. CFD Model Output for The Dalles Dam Forebay Showing the Effects of Block Loading Main Units 1-5 on Forebay Velocities..... 


\section{Tables}

Table 1.1. Major Research Efforts by Study Year from 1982 to 2005 at The Dalles Dam ..................... 1.2

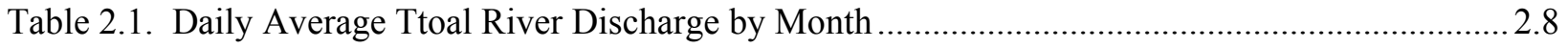

Table 2.2. Species Composition Data from the Smolt Monitoring Program at John Day Dam ..............2.8

Table 3.1. Means of Median Forebay Residence Times (h) from 2003, 2004, and 2005 Studies of

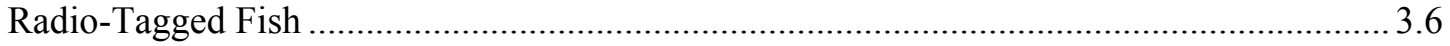

Table 3.2. Summary of Passage Efficiency and Effectiveness of Tagged Juvenile Salmonids at The Dalles Dam.

Table 3.3. Passage Efficiency and Effectiveness for the Run-at-Large at The Dalles Dam from Hydroacoustic Studies during 2001-2005

Table 4.1. Hierarchical Regression for Spill Passage Efficiency Testing the Significance of Spill Proportion and Spill Discharge after Accounting for Significant Environmental Covariates

Table 4.2. Estimates of Survival of Fish Released through Hoses into Spill Bays at The Dalles Dam in 2002

Table 4.3. Estimated Survivals and 95\% Confidence Limits of Radio-Tagged Fish Volitionally Passing the Spillway at The Dalles Dam....

Table 4.4. Median Tailrace Migration Times (minutes) of Radio-Tagged Juvenile Chinook Salmon Passing The Dalles Dam to the Exit Point Transect, 1.7 km Downriver from the Dam ....... 4.11

Table 5.1. Hydraulic Calculations for the Sluiceway at The Dalles Dam, Example for Sluice 1 and both Sluice 1 and 18

Table 5.2. Sluiceway Passage Efficiencies (re: powerhouse) for the Configuration Study during 2005

Table 5.3. Sluiceway Passage Efficiencies (re: individual locations) for the Configuration Study during 2005

Table 6.1. Mean Fish Guidance Efficiency Estimates (\%) for Prototype Intake Screens at The Dalles Dam.

Table 6.2. Results of the Hydroacoustic Evaluation of J-Occlusions at TDA during 2002 2..................6.3

Table 6.3. Sluiceway Passage Efficiency (SLY) for Radio-Tagged Fish at TDA in 2002 ..................... 6.4

Table 6.4. Spillway Passage Efficiency (SPY) for Radio-Tagged Fish at TDA in 2002 ........................6.4

Table 7.1. Summary of Study Timing, Fish Size Statistics, and Tag Specifications for Radio Telemetry Survival Studies at The Dalles Dam, 2001-2006

Table 7.2. Survival Estimates for yearling and subyearling Chinook salmon passing The Dalles Dam in 2002, 2004, and 2005.

Table 7.3. Survival Estimates for Yearling and Subyearling Chinook Salmon Passing The Dalles Dam Sluiceway, 2001 and 2004

Table 7.4. Mean Survival Estimates from Radio Telemetry Studies in 2002, 2004, and 2005 


\section{Acronyms and Abbreviations}

\begin{tabular}{|c|c|c|c|}
\hline AFEP & Anadromous Fish Evaluation Program & $\mathrm{m}$ & meter \\
\hline $\mathrm{BN}$ & north side of mid-river barge & MSL & mean sea level \\
\hline BPA & Bonneville Power Administration & MU & main unit \\
\hline $\mathrm{BS}$ & south side of mid-river barge & MW & megawatt \\
\hline BRZ & boat restricted zone & NMFS & National Marine Fisheries Service \\
\hline $\mathrm{C}$ & centigrade & NPM & northern pikeminnow \\
\hline CFD & computational fluid dynamics & NR & not reported \\
\hline $\mathrm{cfs}$ & cubic feet per second & NS & not sampled \\
\hline $\mathrm{CH} 0$ & subyearling Chinook salmon & PIT & passive integrated transponder \\
\hline $\mathrm{CH} 1$ & yearling Chinook salmon & PNNL & $\begin{array}{l}\text { Pacific Northwest National } \\
\text { Laboratory }\end{array}$ \\
\hline $\mathrm{CI}$ & confidence interval & Q & discharge \\
\hline DIDSON & Digital Identification Sonar & SE & standard error \\
\hline DSP & digital spectrum processors & SL & sluice \\
\hline EL & elevation & SLY & sluice passage efficiency \\
\hline ERDC & $\begin{array}{l}\text { Engineering Research and Development } \\
\text { Center }\end{array}$ & SMB & smallmouth bass \\
\hline ESBS & extended-length submersible bar screen & SMP & Smolt Monitoring Program \\
\hline ESTS & $\begin{array}{l}\text { extended-length submersible traveling } \\
\text { screen }\end{array}$ & SPY & spill passage efficiency \\
\hline FCRPS & Federal Columbia River Power System & SS & south shore \\
\hline FGE & fish guidance efficiency & ST & yearling steelhead \\
\hline FPE & fish passage efficiency & STS & submersible traveling screens \\
\hline fps & feet per second & TDA & The Dalles Dam \\
\hline $\mathrm{ft}$ & feet & USACE & U.S. Army Corps of Engineers \\
\hline FU & fish unit & USGS & U.S. Geological Survey \\
\hline GPS & global positioning system & UW & University of Washington \\
\hline $\mathrm{h}$ & hour & $\mathrm{ZOI}$ & zone of influence \\
\hline JBS & juvenile bypass system & & \\
\hline $\mathrm{kcfs}$ & thousand cubic feet per second & & \\
\hline $\mathrm{km}$ & kilometer & & \\
\hline
\end{tabular}




\subsection{Introduction}

Research studies to develop long-term measures to protect juvenile salmonids at The Dalles Dam (TDA; Figure 1.1) are a high priority in the endeavor to increase their survival. The general goal of the studies is to provide information on passage at The Dalles Dam to inform decisions on structures and operations designed to improve passage survival rates. Fish passage improvement strategies address the three primary passage routes at The Dalles Dam - the spillway, sluiceway, and turbines with the general intent being to increase spill and sluice passage and decrease turbine passage. Since the review by Ploskey et al. (2001a) of research covering 1982-2000 at The Dalles Dam (Volume I of The Dalles Dam Juvenile Salmonid Passage synthesis series), the U.S. Army Corps of Engineers Portland District (USACE) has funded over \$20M of research in 40 studies between 2001 and 2005, inclusive (Table 1.1). The review herein was conducted by the Pacific Northwest National Laboratory (PNNL) and the U.S. Geological Survey (USGS) for the USACE to synthesize juvenile salmonid passage data at The Dalles Dam collected during 2001-2005.

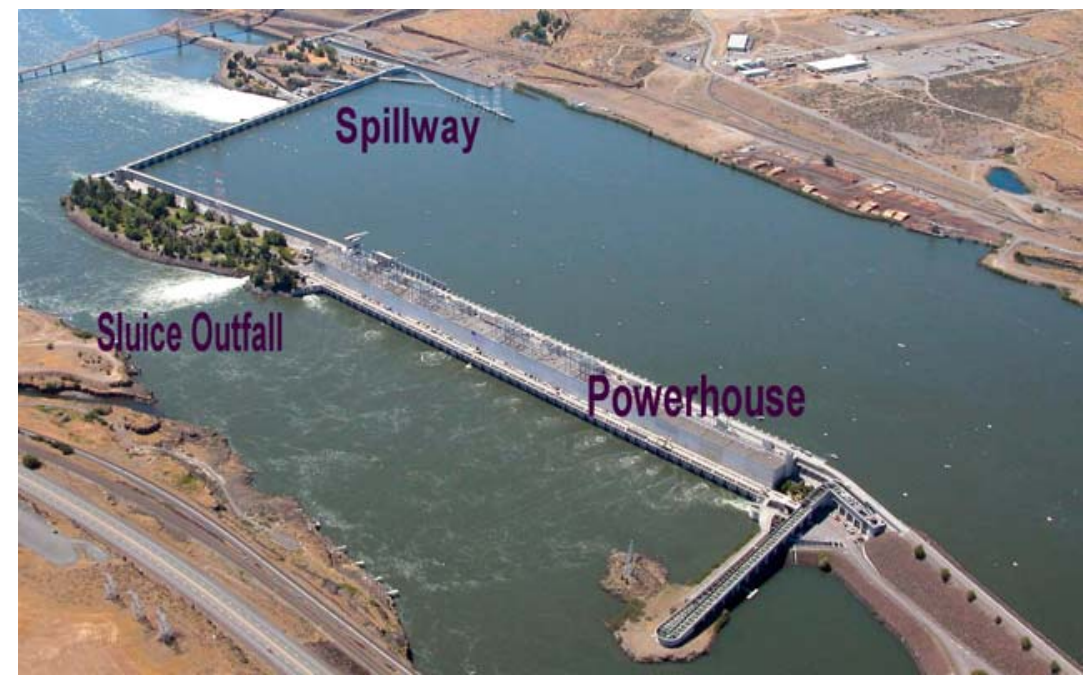

Figure 1.1. Aerial Photograph of The Dalles Dam (Courtesy of D. Feil, USACE)

\subsection{Background}

Many research tools and techniques have been employed at The Dalles Dam to collect fish passage data since the early 1980s, including fyke nets, balloon tags, PIT-tags, Sensor Fish, acoustic telemetry, a sonar tracker, underwater video, an acoustic camera (DIDSON), and mobile hydroacoustic surveys (Table 1.1). However, radio telemetry and fixed hydroacoustics have been the most common assessment techniques, starting with applications in the 1980s that were primarily feasibility studies and ending with the sophisticated methods in use today. Early success using tagged fish indicated that juvenile salmon could be tracked as they approached, passed, and egressed at The Dalles Dam powerhouse and spillway. Reductions in tag size along with improvements in monitoring hardware have allowed researchers to tag smaller fish and track multiple tags simultaneously, providing data to quantify passage rates at specific as opposed to general passage routes. The telemetry methods provide species-specific estimates of passage of fish with known 
histories, but telemetry studies require handling the study animals and are limited in sample size relative to fixed hydroacoustics. In addition, data from tagged fish are useful in determining speciesspecific passage locations and rates. Although overall diel passage rates may be biased by release timing, diel patterns in rates of passage are unbiased.

Table 1.1. Major Research Efforts by Study Year from 1982 to 2005 at The Dalles Dam. Study codes correspond to study methodology: A - acoustic telemetry; B - balloon tags; D DIDSON; $\mathrm{F}$ - fyke net; $\mathrm{G}$ - drogues; $\mathrm{H}$ - fixed hydroacoustics; $\mathrm{M}$ - mobile hydroacoustics; P- PIT tag; R - radio telemetry; S - Sensor Fish; T - sonar tracker; V underwater video. The shaded studies are covered in this synthesis report. *indicates the research was part of the FPE study and is not included in the total count of studies.

\begin{tabular}{|c|c|c|c|c|c|c|c|c|c|c|c|c|c|c|c|c|c|c|c|c|c|c|c|c|}
\hline Research & 82 & 83 & 84 & 85 & 86 & 87 & 88 & 89 & 90 & 91 & 92 & 93 & 94 & 95 & 96 & 97 & 98 & 99 & 00 & 01 & 02 & 03 & 04 & 05 \\
\hline $\begin{array}{l}\text { FPE and } \\
\text { Spill } \\
\text { Efficiency }\end{array}$ & $\mathrm{H}$ & & & $\mathrm{H}$ & $\mathrm{H}$ & & & & $\mathrm{H}$ & & & & & $\mathrm{H}$ & $\mathrm{H}$ & & $\mathrm{H}$ & $\begin{array}{l}\mathrm{H} \\
\mathrm{R}\end{array}$ & $\begin{array}{l}\mathrm{H} \\
\mathrm{R}\end{array}$ & $\begin{array}{l}\mathrm{H} \\
\mathrm{R}\end{array}$ & $\begin{array}{l}\mathrm{H} \\
\mathrm{R}\end{array}$ & $\mathrm{R}$ & $\begin{array}{l}\mathrm{H} \\
\mathrm{R}\end{array}$ & $\mathrm{R}$ \\
\hline $\begin{array}{l}\text { Survival, } \\
\text { Injury }\end{array}$ & & & & & & & & & & & & & & & B & $\mathrm{P}$ & $\mathrm{P}$ & $P$ & $\begin{array}{l}\mathrm{P} \\
\mathrm{R}\end{array}$ & $\begin{array}{l}\text { B } \\
\text { R } \\
\text { S }\end{array}$ & $\begin{array}{l}\mathrm{B} \\
\mathrm{R} \\
\mathrm{S}\end{array}$ & $\begin{array}{l}\mathrm{B} \\
\mathrm{S}\end{array}$ & $\begin{array}{l}\mathrm{B} \\
\mathrm{R} \\
\mathrm{S}\end{array}$ & $\mathrm{R}$ \\
\hline $\begin{array}{l}\text { Egress, } \\
\text { Predation }\end{array}$ & & & & & & & & & & & $\mathrm{R}$ & $\mathrm{R}$ & $\mathrm{R}$ & $\mathrm{R}$ & $\mathrm{R}$ & $\mathrm{R}$ & & $\begin{array}{l}\mathrm{G} \\
\mathrm{R}\end{array}$ & $\mathrm{G}$ & $\begin{array}{l}\mathrm{G} \\
\mathrm{R}\end{array}$ & $\mathrm{R}$ & $\mathrm{R}$ & $\mathrm{R}$ & $\begin{array}{l}\mathrm{G} \\
\mathrm{R}\end{array}$ \\
\hline $\begin{array}{l}\text { Forebay } \\
\text { Behavior }\end{array}$ & & & & & & & & & & & & $\mathrm{R}$ & & $\mathrm{R}$ & $\mathrm{R}$ & $\mathrm{R}$ & & $\mathrm{R}$ & & & & $\begin{array}{l}\mathrm{M} \\
\mathrm{R}\end{array}$ & $\begin{array}{l}\mathrm{A} \\
\mathrm{R}\end{array}$ & $\mathrm{R}$ \\
\hline $\begin{array}{l}\text { Sluiceway } \\
\text { Passage }\end{array}$ & $F$ & & & $\mathrm{H}$ & $\mathrm{H}$ & & & & & & & & & $\mathrm{H}$ & $\mathrm{H}$ & & $\mathrm{H}$ & $\begin{array}{c}\mathrm{H} \\
\mathrm{R}^{*}\end{array}$ & $\begin{array}{c}\mathrm{H} \\
\mathrm{R}^{*} \\
\mathrm{~T}\end{array}$ & $\begin{array}{c}\mathrm{H} \\
\mathrm{R}^{*} \\
\mathrm{~T}\end{array}$ & $\begin{array}{c}\mathrm{H} \\
\mathrm{R}^{*} \\
\mathrm{~T}\end{array}$ & $\mathrm{R}^{*}$ & $\begin{array}{c}\mathrm{H} \\
\mathrm{R}^{*} \\
\mathrm{D}\end{array}$ & $\begin{array}{c}\mathrm{H} \\
\mathrm{R}^{*} \\
\mathrm{D}\end{array}$ \\
\hline Turbines & & & & $\mathrm{F}$ & $\mathrm{F}$ & & & & & & & $\begin{array}{l}\mathrm{F} \\
\mathrm{V}\end{array}$ & $\mathrm{F}$ & $\mathrm{F}$ & & & & $\mathrm{R}^{*}$ & $\mathrm{R}^{*}$ & $\begin{array}{l}\mathrm{H}^{*} \\
\mathrm{R}^{*}\end{array}$ & $\begin{array}{l}\mathrm{H}^{*} \\
\mathrm{R}^{*}\end{array}$ & $\mathrm{R}^{*}$ & $\mathrm{R}^{*}$ & $\mathrm{R}^{*}$ \\
\hline Total & 2 & 0 & 0 & 3 & 3 & 0 & 0 & 0 & 1 & 0 & 1 & 4 & 2 & 5 & 5 & 3 & 3 & 7 & 7 & 9 & 8 & 6 & 10 & 7 \\
\hline
\end{tabular}

Hydroacoustic technology has undergone similar advances, including improvements in hardware and software that have allowed researchers to sample at relatively high pulse-repetition rates, determine the direction of fish movement across split-beams, and more accurately quantify and account for differences in fish detectability among and within sampled volumes. Estimates from fixed hydroacoustic techniques applied at The Dalles Dam, however, cannot distinguish among species. Hydroacoustic estimates are valuable because they are usually based on large sample sizes that are amenable to statistical comparisons of fish passage rates under various experimental treatments and they provide data $24 \mathrm{~h} / \mathrm{d}$ continuously during spring and summer juvenile salmonid migrations.

Specific study objectives determined the sampling tools. Most of the fish passage efficiency (FPE) and spill efficiency studies have involved radio telemetry and fixed hydroacoustics. Survival and injury investigations used mark-recapture techniques involving balloon, PIT, and radio tags. Forebay approach and tailrace egress and predation studies used telemetry. Sluiceway studies used sonar tracker and DIDSON technologies to examine fish behavior in the sluiceway nearfield, while radio telemetry and fixed hydroacoustics were used to determine sluice passage rates. Turbine research used fyke nets and underwater video, along with radio telemetry and hydroacoustics. 


\subsection{Objective}

The objective of this report is to summarize and synthesize data on juvenile salmonid passage at The Dalles Dam collected during 2001-2005. Such data include forebay approach paths, vertical, horizontal, and diel passage distributions, passage efficiencies for the spillway, sluiceway, and project as a whole, tailrace egress and predation rates, and route-specific and total project survival rates. These data support efforts to improve passage conditions for juvenile salmonids at The Dalles Dam.

\subsection{Overview of this Report}

This review of 2001-2005 data on fish passage at The Dalles Dam is organized by the major fish passage research efforts during this period (Table 1.1). The Environmental Setting (Section 2) provides context for the subsequent research summaries. Forebay and Project Passage Studies (Section 3) are fundamental to understanding where and when downstream migrant anadromous fish pass the dam. Furthermore, passage efficiency data are used to prorate route-specific survival estimates into project-wide survival data. Spill Studies (Section 4) concern spill operations, the spillwall, and other spill-related efforts. For some time, spill has been the top priority fish protection measure at The Dalles Dam. Before water was spilled for fish protection at The Dalles Dam, dam operators opened sluice gates to pass juvenile salmonids. The sluiceway continues to be a basic element for juvenile fish protection at The Dalles Dam. Sluiceway Studies are described in Section 5. Turbine Studies (Section 6) entailed prototype intake screens and trash rack occlusions. Results from Survival Studies (Section 7) influence fish protection measures, such as voluntary spill operations. Volumes I and II of the synthesis cover over 86 technical reports (listed in Appendix A) and provide a resource for engineers, biologists, and dam operators to use when making decisions about fish protection measures for juvenile salmonids at The Dalles Dam. 


\subsection{Environmental and Biological Setting}

The environmental setting entails a project description, river conditions, project operations, species composition, and run timing during 2001-2005.

\subsection{Project Description}

The Dalles Dam, located at river mile 192, is the second closest dam to the Pacific Ocean in the Federal Columbia River Power System. The Dalles Dam includes a navigation lock, a spillway perpendicular to the main river channel, and a powerhouse parallel to the main river channel with non-overflow dams on each side (Figure 2.1). The Dalles Dam is the only Portland District project that has the powerhouse running parallel instead of perpendicular to the main channel of the Columbia River. Full pool elevation is rated at $160 \mathrm{ft}$ above mean sea level (MSL) and minimum operating pool elevation is $155 \mathrm{ft}$. The thalweg intersects the dam at the eastern end of the powerhouse and, although there are deep areas immediately in front of the powerhouse (Figure 2.1), much of the forebay is relatively shallow ( $<65 \mathrm{ft}$ deep). There are deep canyons, shallow sills, and islands in the tailrace (Figure 2.2).

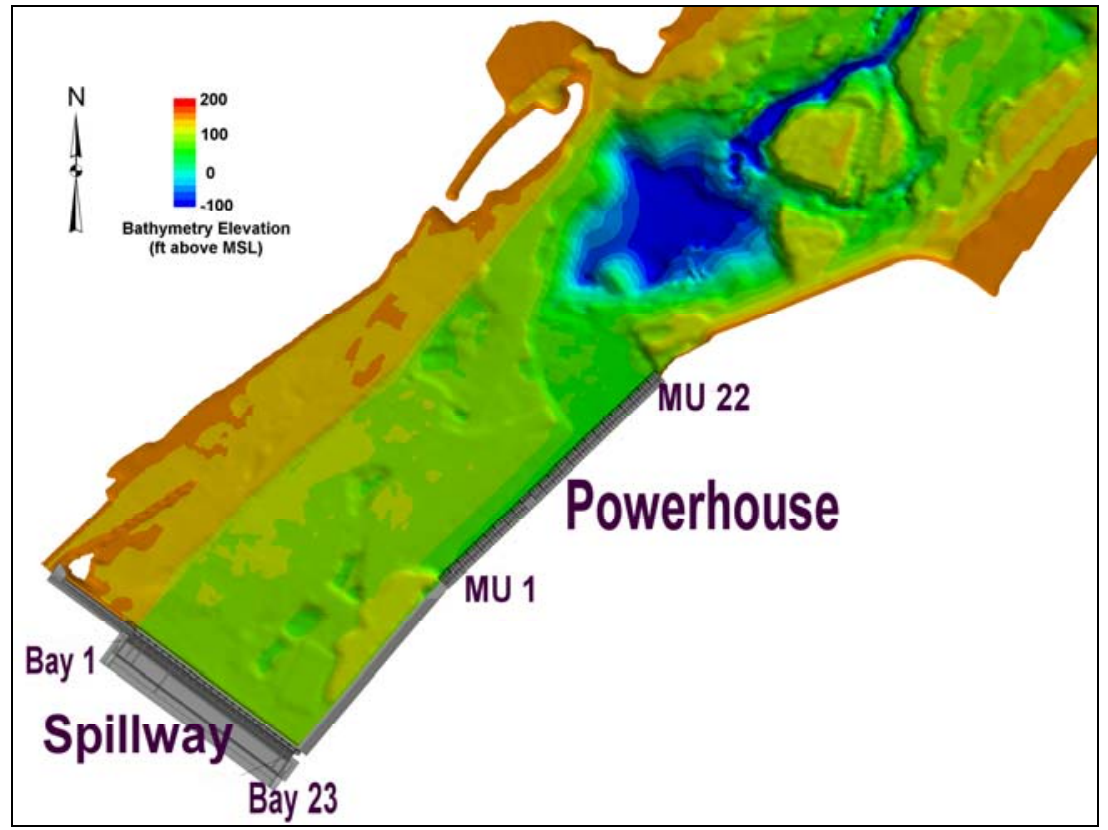

Figure 2.1. Plan View of The Dalles Dam Showing Forebay Bathymetry (Modified from an image provided by J. Serkowski, PNNL Hydrology)

The powerhouse is $2,089 \mathrm{ft}$ long with a total generating capacity of 1,800 megawatt (MW) and total hydraulic capacity of 330 thousand cubic feet per second ( $\mathrm{kcfs}$ ). The powerhouse has two fish units (Fish Unit [FU] 1 and FU 2) and 22 main units (MU), numbered from the southwest (downstream) to the northeast (upstream) end. Each main unit has three intakes, numbered again from southwest to northeast. Reference to a specific intake is expressed as the turbine unit and intake number, e.g., 2-3 for the east intake of MU 2. Main units usually are operated within $1 \%$ of peak efficiency to reduce unit cavitation and injury to juvenile fish. Flow through the main units can range 
from about 9,000 to 14,000 cfs depending upon efficiency, head, desired power output, and other factors. Flow typically averages about $11,000 \mathrm{cfs}$ per main unit. Two fish units are located southwest of MU 1; the fish units have only two intakes each. Average discharge through the fish units is about $2,000 \mathrm{cfs}$. The turbine intake ceiling intersects the trash racks at elevation $141 \mathrm{ft}$. The face of the powerhouse is $11.3^{\circ}$ off vertical.

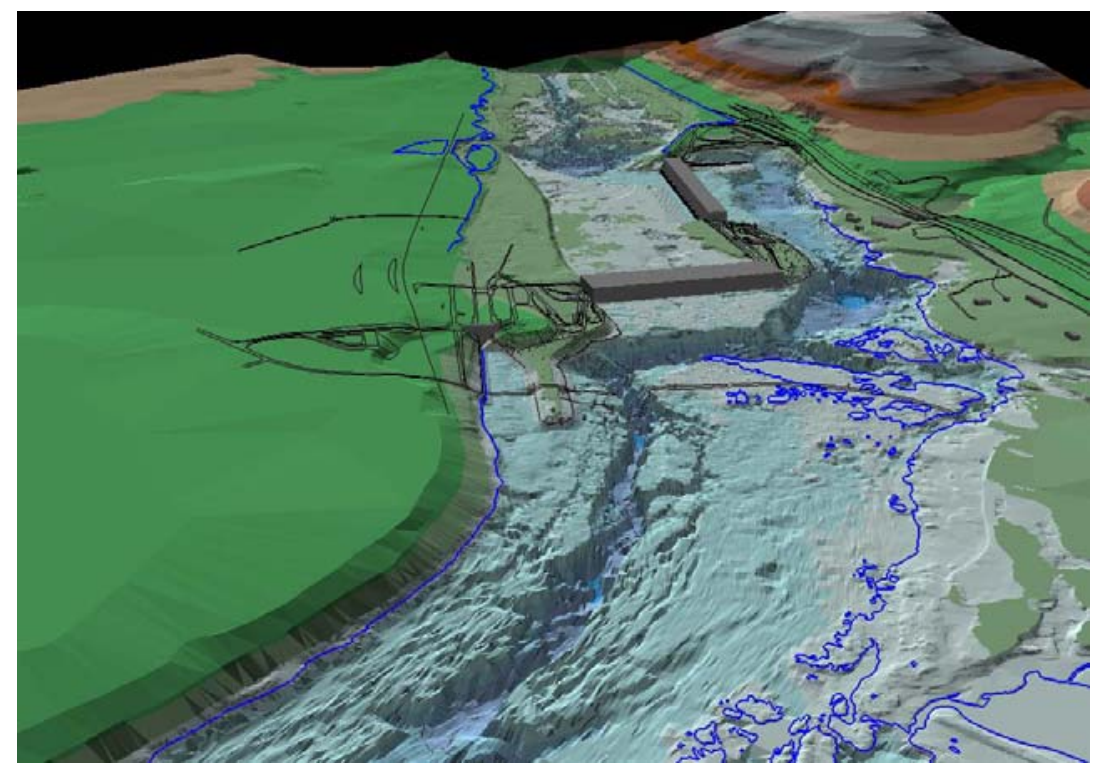

Figure 2.2. Perspective View of The Dalles Dam Showing Tailrace Bathymetry (Provided by L. Ebner, USACE Hydraulics)

The 1,380-ft-long spillway is comprised of 23 bays with 50 -ft-wide radial gates numbered sequentially from the Washington to the Oregon side. Individual spill-gate openings typically range from 0 to $14 \mathrm{ft}$ with about 1,500 cfs of flow per foot of opening. The tailrace for the powerhouse is deep, but further downstream on the Oregon side it is shallow and has many islands and rock outcrops (Figures 2.2 and 2.3). The spillway was modified during winter 2003/2004 to include a spillwall 193 $\mathrm{ft}$ long that divides the stilling basin between Bays 6 and 7 .

The ice and trash sluiceway is a channel that extends the entire length of the forebay side of the powerhouse. The sluiceway has three 20 -ft-wide entrance gates positioned over each of the 22 turbine units. Water enters the sluiceway channel from the forebay when gates are moved off the sill at elevation $151 \mathrm{ft}$. A maximum of six sluice gates can be opened at any time before reaching the hydraulic capacity of the channel $(\sim 4,500 \mathrm{cfs})$. Flow into the sluiceway is dependent on forebay elevation and the number and location of open gates. For instance, given a forebay elevation equal to $158.4 \mathrm{ft}$ (above mean sea level) and two sluice gate operating conditions (see above), flows over the individual weir gates range from 561 to $1,059 \mathrm{cfs}$ with the highest flows at the west end nearest the sluiceway channel outlet. Overall, sluiceway discharge ( 4,500 cfs) is a relatively small proportion of total project discharge $(\sim 2 \%)$. The ice and trash sluiceway has long been operated to pass juvenile salmonids at TDA. During 2001-2003, the three sluice gates above MU 1 were opened to release about 3,600 cfs during April-December. In 2004 and 2005, additional gates were opened to maximize sluiceway discharge at about $4,500 \mathrm{cfs}$. 


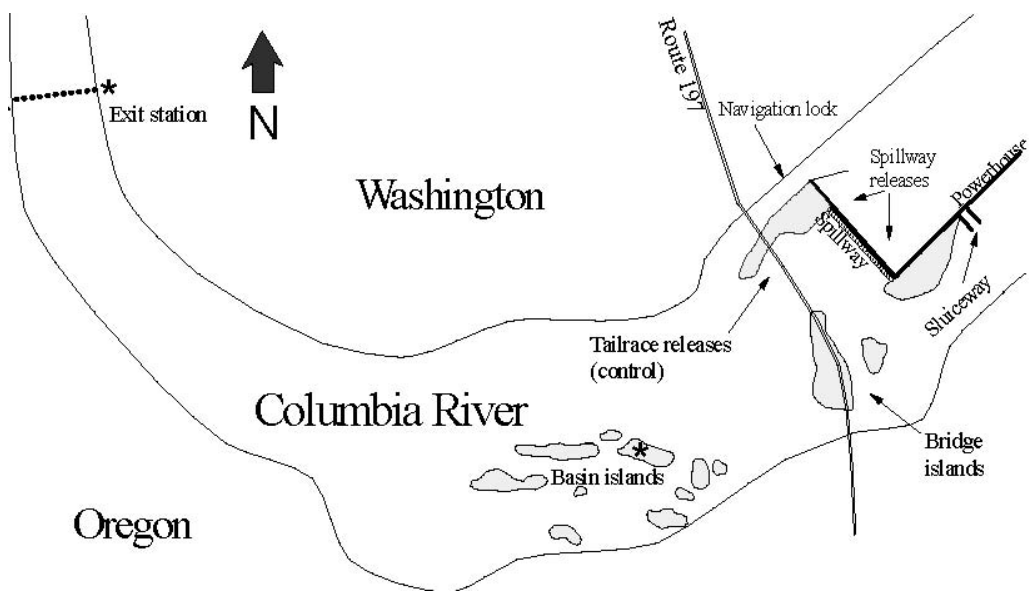

Figure 2.3. Plan View of The Dalles Dam Tailrace and Shoreline Showing Spillway, Sluiceway, and Powerhouse Outlets and Bridge and Basin Islands. Map distances are not to scale. (Provided by T. Liedtke, Columbia River Research Laboratory, USGS.)

\subsection{River Conditions}

River discharge during 2001-2005 varied annually (Figure 2.4). The highest daily flows at about $350 \mathrm{kcfs}$ occurred in June 2002. The lowest daily flows (less than $50 \mathrm{kcfs}$ ) occurred in July 2001. Except for 2001, an extremely low-flow year (46\% of the 10 -year average), river discharge at The Dalles Dam typically peaked in late May and June and was lowest in September (Figure 2.4). The 2002 hydrograph was unusual in that it was bimodal with peaks in April and June (Figure 2.4). Daily average total river discharge (kcfs) by month in shown in Table 2.1.

Table 2.1. Daily Average Total River Discharge (kcfs) by Month (from www.cbr.washington.edu)

\begin{tabular}{lccccc}
\hline & 2001 & 2002 & 2003 & 2004 & 2005 \\
\hline April & 113 & 213 & 198 & 158 & 140 \\
May & 134 & 232 & 238 & 214 & 226 \\
June & 129 & 317 & 241 & 222 & 189 \\
July & 86 & 225 & 142 & 144 & 168 \\
August & 96 & 147 & 125 & 124 & 129 \\
\hline
\end{tabular}

Water temperature typically increased steadily from late winter values below $8^{\circ} \mathrm{C}$ to peak values around $22^{\circ} \mathrm{C}$ in August (Figure 2.5). Temperatures were slightly higher $\left(1-2^{\circ} \mathrm{C}\right)$ in 2003 and 2004 than 2001 and 2002. 

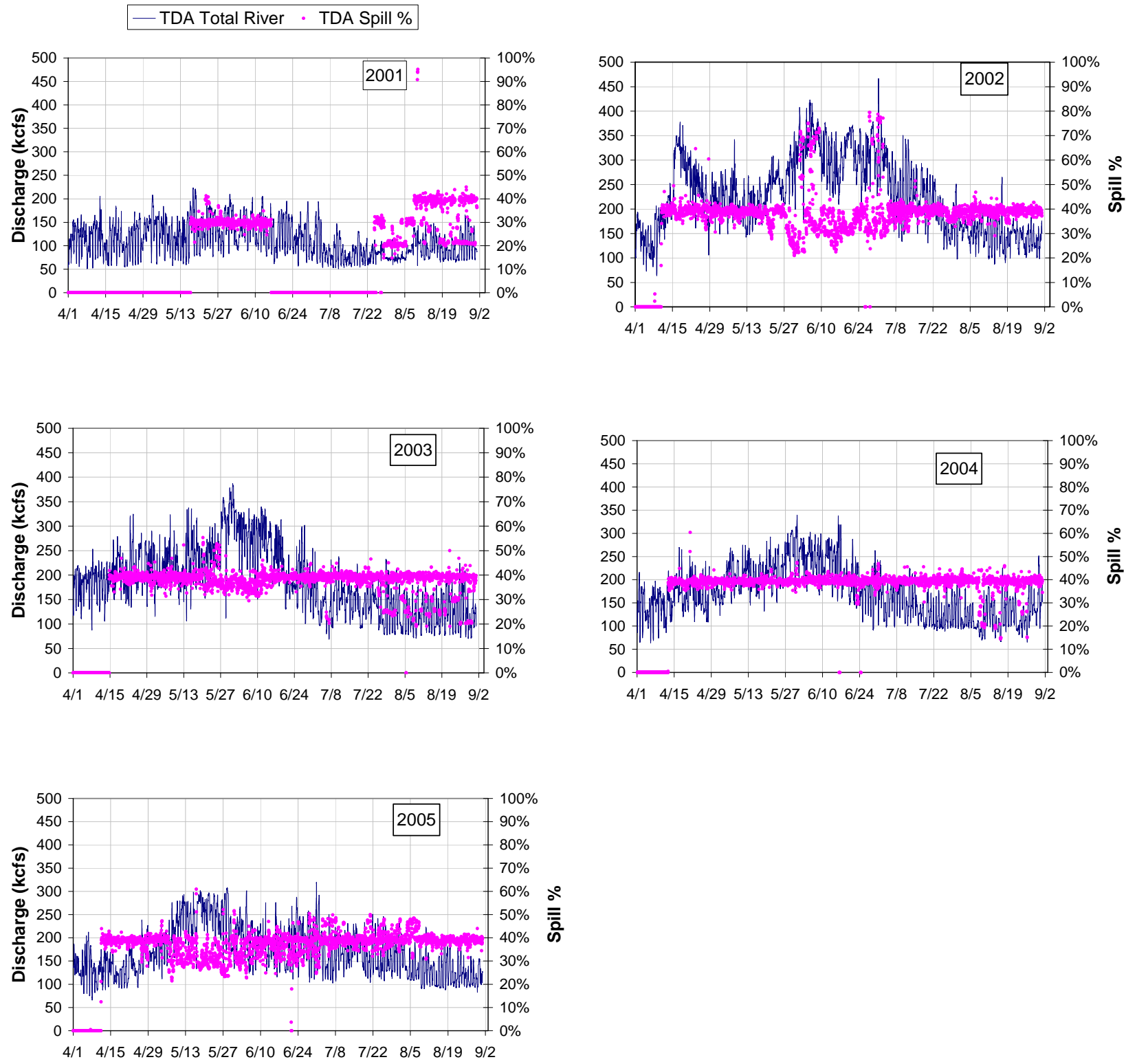

Figure 2.4. River Discharge (kcfs) and Spill Percentage at The Dalles Dam, 2001-2005 (Provided by L. Ebner, USACE Hydraulics) 


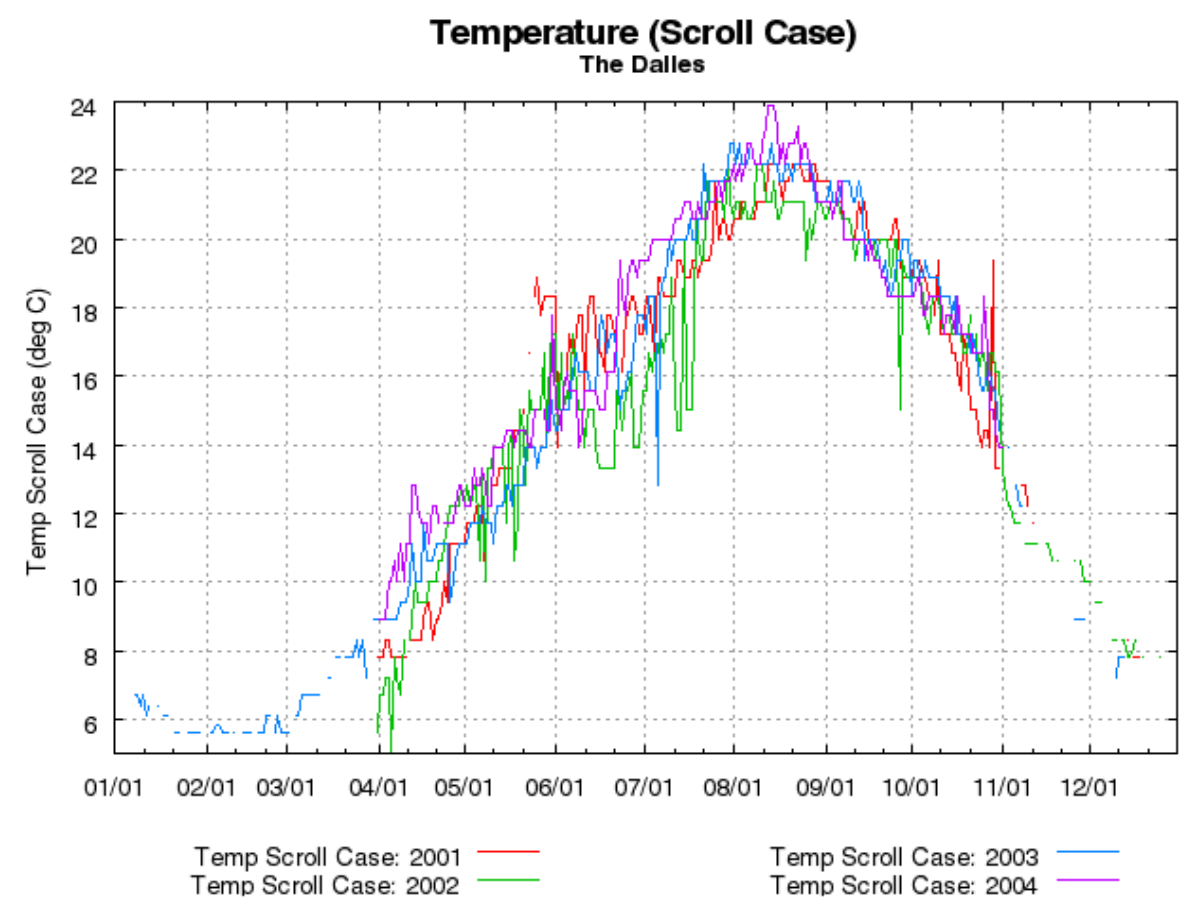

Figure 2.5. Temperature (deg C) at The Dalles Dam, 2001-2004. Data for 2005 were not available. (Obtained from DART http://www.cbr.washington.edu/dart/ on Dec. 21, 2006.)

\subsection{Project Operations}

The Dalles Dam is centrally located in the Bonneville Power Administration's (BPA) electricity transmission system for the Federal Columbia River Power System (FCRPS). The dam is in the southern portion of the suite of hydroelectric generating stations in the FCRPS and it is at the northern terminus of the 2,100-MW direct current line to Los Angeles. Due to its capacity for high generation, the dam is at the head of three alternating current tie lines heading south. The Dalles Dam provides critical system voltage support, especially during periods of voluntary fish spill, by using turbine units capable of synchronous condenser operation (MU 15-20). Operators start these particular units by discharging water, then the wicket gates are closed and compressed air is used to evacuate the water away from the turbine. With the units still connected to the grid, they act as big electric motors. Operations at The Dalles Dam provide support to the transmission grid in the Pacific Northwest and California that help avert regional power outages.

The Dalles Dam is a run-of-river project that is used to follow electrical loads in conjunction with other dams in the power system. Turbine discharge, and hence electricity generation, typically peaks during the daytime and evening hours. This pattern can produce large (40-50 kcfs) differences between daily minimum and maximum discharges on average (Figure 2.6) with instances of up to 100-kcfs differences within some days. 


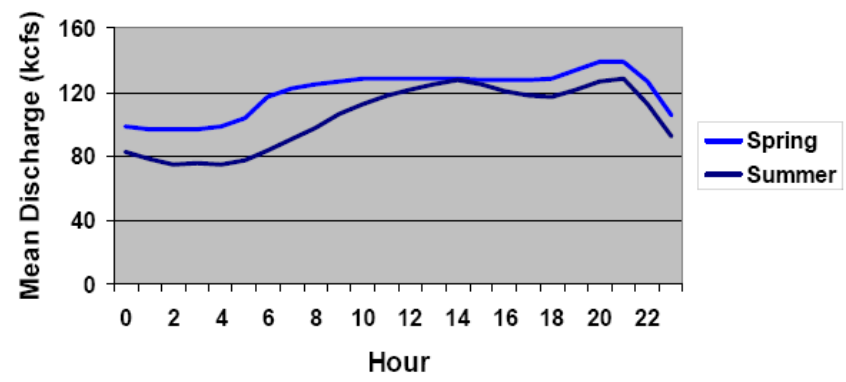

Figure 2.6. Example of Load Following as Shown by the Diel Distribution of Turbine Discharge at The Dalles Dam during Spring (April 18 - June 4) and Summer (June 5 - July 16) 2005

During 2001-2005, spill discharge ranged from 0 to almost $200 \mathrm{kcfs}$ (Figure 2.7). About $40 \%$ of total river discharge was typically spilled for juvenile passage in a north-oriented pattern $24 \mathrm{~h} / \mathrm{d}$ from April 10 to August 31. After the spillwall was completed in early 2004, the spill pattern was designed to place the bulk of spill discharge $24 \mathrm{~h} / \mathrm{d}$ through Bays 1-6 (Figure 2.8). Total river discharge and the percentage of spill can fluctuate widely from day to day at The Dalles Dam (Figure 2.4).

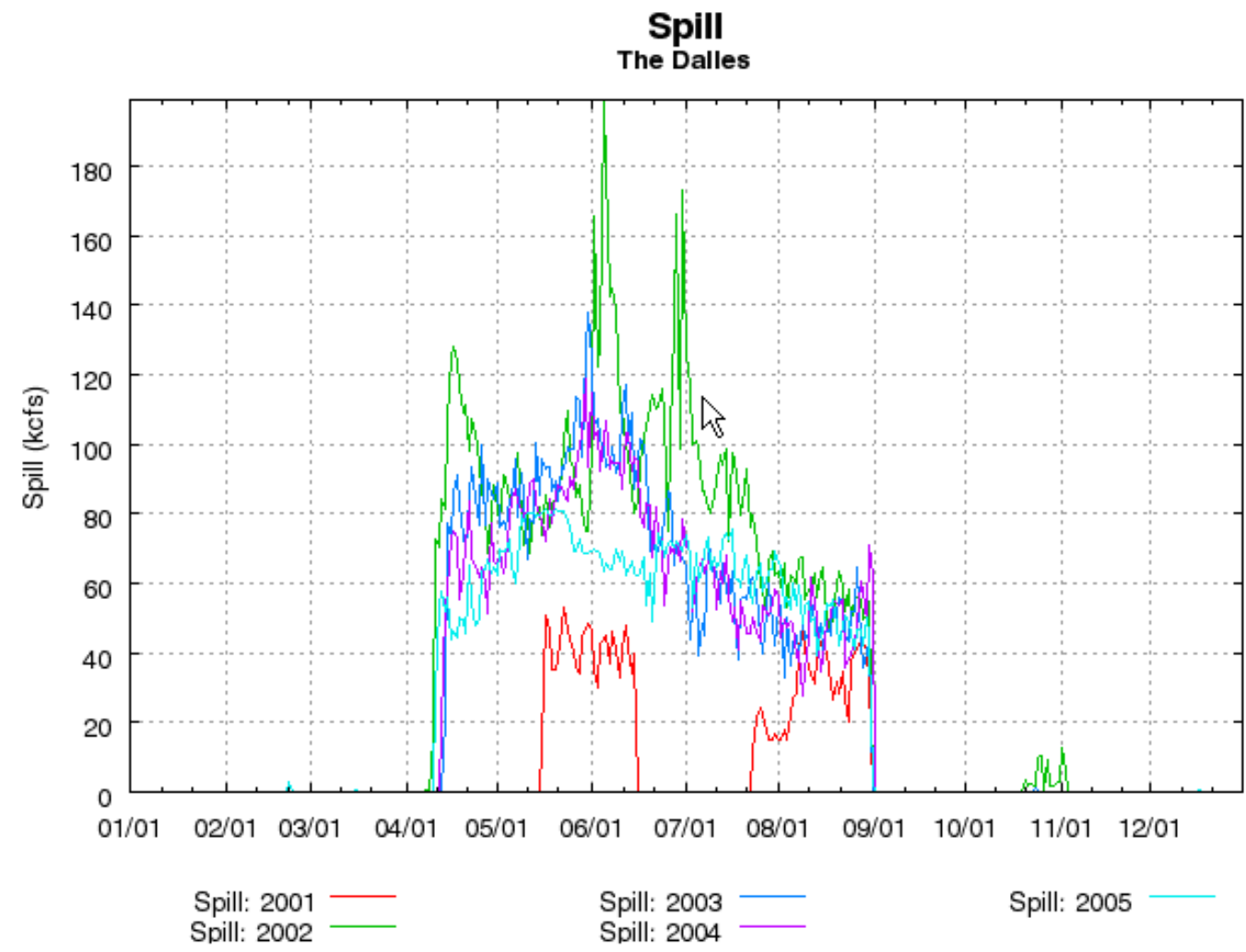

Figure 2.7. Spill Discharge (kcfs) at The Dalles Dam, 2001-2005 (Obtained from DART) 


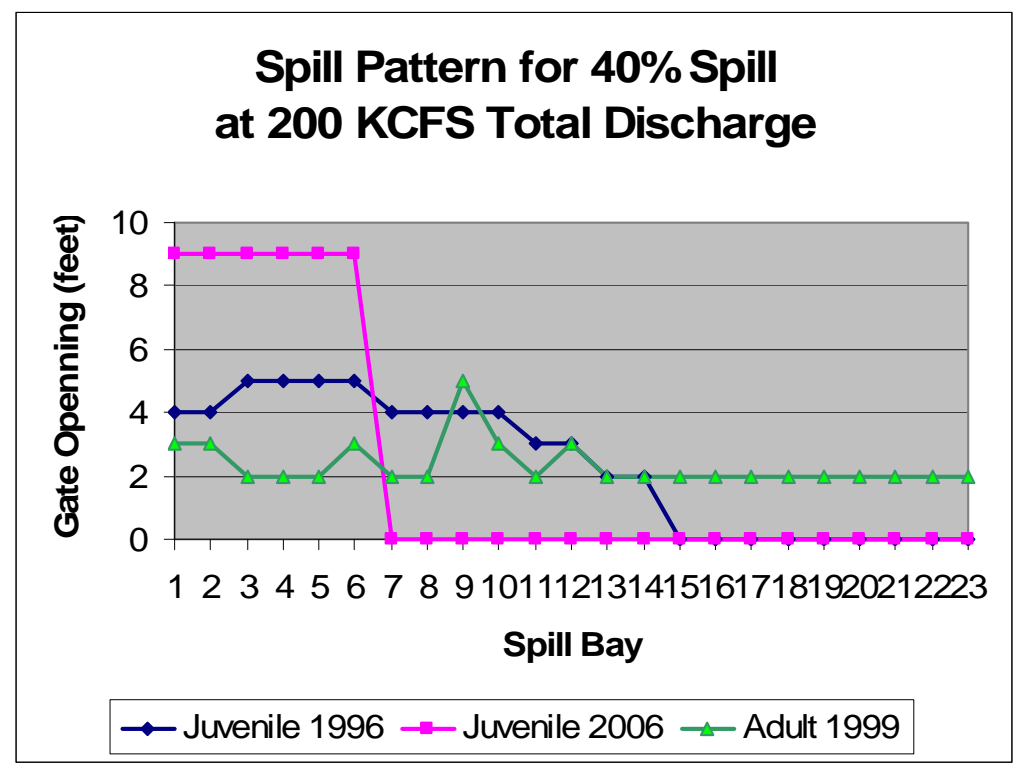

Figure 2.8. Schematic of Spill Gate Openings of Juvenile and Adult Spill Patterns

\subsection{Species Composition and Run Timing}

Although juvenile salmonid monitoring is not conducted at The Dalles Dam, data on smolt migration characteristics there can be based on the Smolt Monitoring Program's (SMP) sampling at John Day Dam and information on hatchery releases in the Deschutes River drainage. John Day Dam is the nearest upstream dam with smolt monitoring facilities. It is generally representative of species composition and run timing at The Dalles Dam because the travel time from John Day Dam to The Dalles Dam is about one day based on radio telemetry data. There is only one significant tributary between the two dams, the Deschutes River. The following salmonid species migrate downstream past The Dalles Dam: yearling and subyearling Chinook salmon (Oncorhynchus tshawytscha), steelhead trout (O. mykiss), sockeye salmon (O. nerka), and coho salmon (O. kisutch).

During April through August 2001-2005, species composition at The Dalles Dam, based on monitoring data from John Day Dam, was 50\% subyearling Chinook salmon, 30\% yearling Chinook salmon, $8 \%$ steelhead, $8 \%$ sockeye salmon, and $4 \%$ coho salmon (Table 2.2 ). These percentages do not incorporate approximately 1 million hatchery yearling Chinook salmon released annually into the Deschutes River. 
Table 2.2. Species Composition Data from the Smolt Monitoring Program at John Day Dam (Data were obtained from DART)

\begin{tabular}{c|rrrrr|rc}
\hline Year & \multicolumn{1}{|c}{ CH 0 } & \multicolumn{1}{c}{ CH 1 } & Coho & Sockeye & \multicolumn{1}{c}{ ST } & Total & Proportion \\
\hline 2001 & $2,466,154$ & $1,000,859$ & 78,113 & 103,314 & 189,465 & $3,837,905$ & 0.152 \\
2002 & $3,371,207$ & $2,109,143$ & 316,462 & 935,602 & 545,526 & $7,277,940$ & 0.288 \\
2003 & $2,690,693$ & $2,064,861$ & 258,191 & 725,774 & 549,412 & $6,288,931$ & 0.249 \\
2004 & $1,716,398$ & 996,426 & 175,261 & 235,899 & 256,190 & $3,380,174$ & 0.134 \\
2005 & $2,292,140$ & $1,376,038$ & 192,277 & 84,421 & 524,804 & $4,469,680$ & 0.177 \\
\hline Total & $12,536,592$ & $7,547,327$ & $1,020,304$ & $2,085,010$ & $2,065,397$ & $25,254,630$ & \\
Proportion & 0.496 & 0.299 & 0.040 & 0.083 & 0.082 & & \\
\hline
\end{tabular}

Run size and timing varies from year to year (Table 2.2 and Figure 2.9). Total run size was about twice as high in 2002 and 2003 as it was in 2001 and 2004. Sockeye and coho salmon pass in the lowest numbers, whereas yearling Chinook salmon and steelhead are more abundant and have a more protracted migration (Figure 2.9). Historically, the steelhead run begins around April 20 and ends by mid-June. Yearling Chinook salmon runs begin about April 18 and end by about June 5, and most of the subyearling Chinook salmon runs begin about June 1 and are over by about the end of July. 

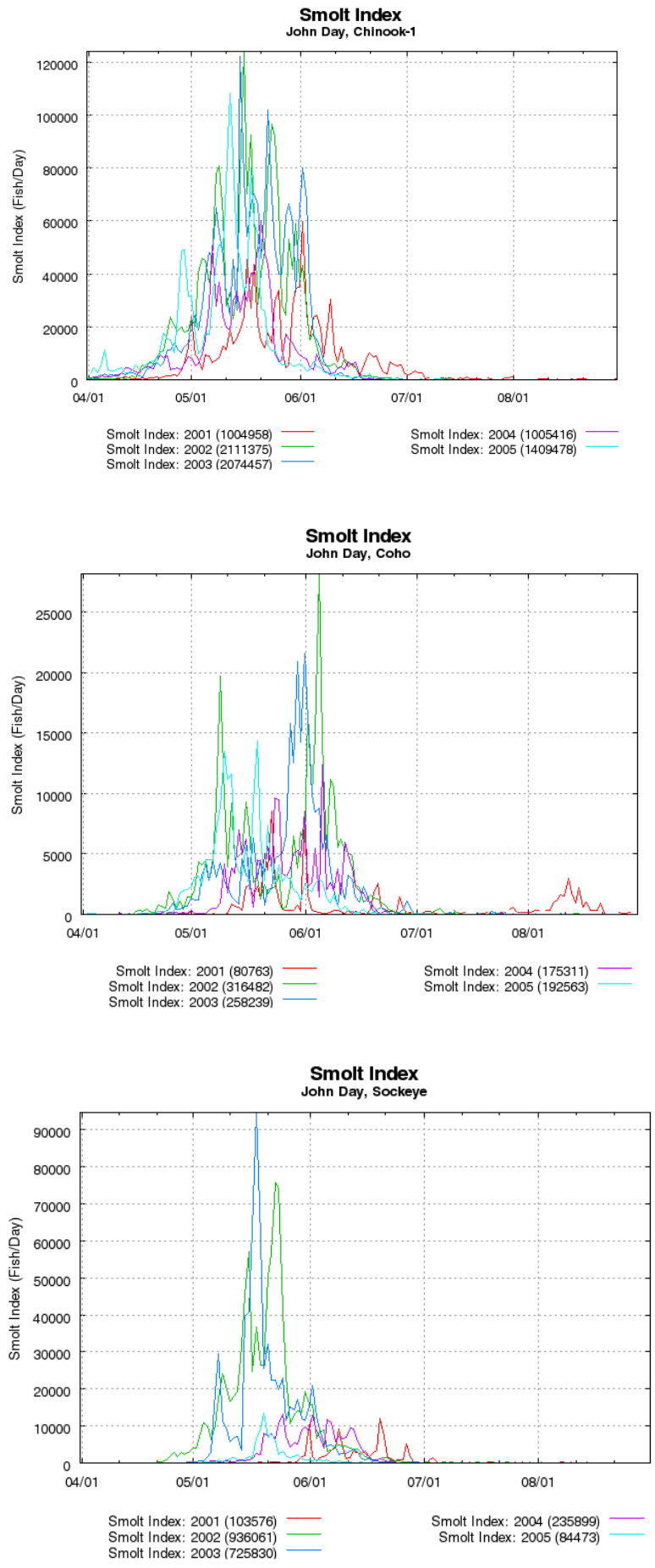
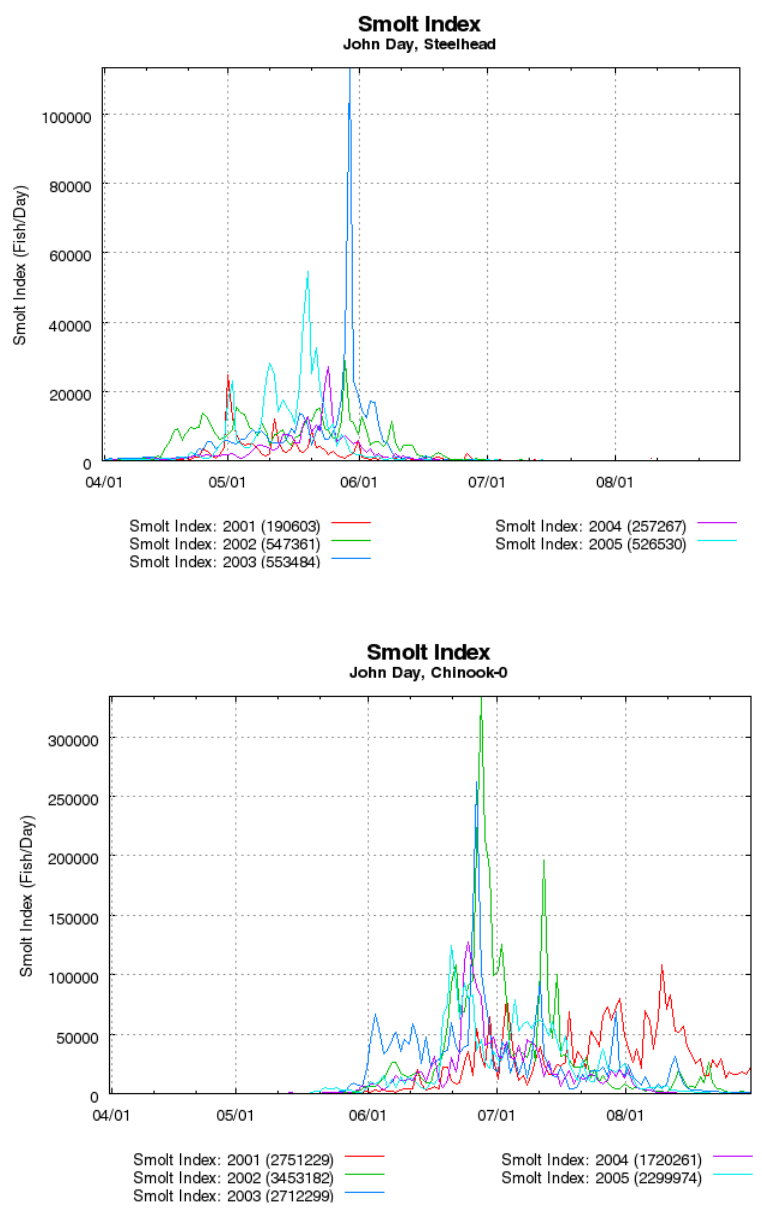

Figure 2.9. Run Timing for April 1 to August 31, 2001-2005 for Yearling Chinook, Coho, and Sockeye Salmon, Steelhead, and Subyearling Chinook Salmon (Graphs were obtained from DART on December 21, 2006) 


\subsection{Summary}

In summary, the environmental and biological setting for juvenile fish passage studies at The Dalles Dam during 2001-2005 was as follows:

- The Dalles Dam plays a key role in BPA's transmission system because it is at the northern terminus of the 2100-MW direct current intertie to Los Angeles and three major alternating current lines. The dam provides critical voltage support to the transmission system that helps avert power outages.

- As a run-of-river project with a forebay elevation operating range of only $5 \mathrm{ft}$, the dam is not designed to store water for the purpose of power peaking. The project, however, is operated as part of a system of hydroelectric generating stations that provide electricity during peak demand periods. As such, total project discharge at The Dalles Dam can vary by as much as $100 \mathrm{kcfs}$ within a given day.

- The Dalles Dam has a reverse L-configuration with the 22-unit, 1,780-MW, 270-kcfs powerhouse parallel to river flow and a 23-bay, radial gate spillway perpendicular to flow. The powerhouse contains a sluiceway that discharges about $4,500 \mathrm{cfs}$ of surface water.

- A 193-ft-long spillwall between Bays 6 and 7 in the stilling basin was installed in winter 2003/2004 to eliminate lateral flows in the stilling basin and channel spill discharge into the thalweg downstream of the dam for the purpose of juvenile fish protection.

- The forebay is relatively shallow ( $<65 \mathrm{ft}$ deep), except for deep areas such as Big Eddy in the river thalweg upstream of the powerhouse. Bathymetry downstream of the dam is characterized by extremely deep thalweg areas, a shallow stilling basin for the spillway, islands, and shallow rocky areas.

- Forebay flow stream lines have two major paths during spill, one to the powerhouse and one to the spillway.

- For the primary juvenile fish passage period (April through August), monthly total river discharge during 2001-2005, expressed as the mean daily discharge, was highest in June 2002 at $317 \mathrm{kcfs}$ and lowest in July 2001 at $86 \mathrm{kcfs}$. The 2001 study year had especially low flows, about $46 \%$ of the 10 year average.

- Voluntary spill for juvenile fish protection at $40 \%$ of total river discharge typically occurs from April 10 to August 31. This spill is bulked in Bays 1-6, unless spill discharge exceeds about $120 \mathrm{kcfs}$, when additional bays are opened as necessary. During 2001-2005, daily spill ranged from 0 to almost 200 kcfs.

- The following salmonids migrate downstream past The Dalles Dam: yearling and sub-yearling Chinook salmon, steelhead trout, sockeye salmon, and coho salmon. The yearling and subyearling migrants mostly pass during spring and summer, respectively. Chinook salmon are the dominant downstream migrant in terms of numbers. 


\subsection{Forebay and Project Passage Studies}

Data on fish behavior during approach and passage at The Dalles Dam were collected to address several management needs. Information on the approach paths, residence times, and eventual routes of passage was used as a basis for comparing spill treatments, designing a prototype guidance structure, and gaining a better understanding of fish passage. Data about the proportions of fish passing the various routes were used to assess overall non-turbine passage and survival by weighting data from each passage route. This chapter also contains sections describing fish passage distributions (horizontal, vertical, and diel) and the hydraulic environment in the forebay.

\subsection{Forebay Biological Data}

Biological data were collected in the forebay of The Dalles Dam during 2003, 2004, and 2005, in addition to previous data reported by Ploskey et al. (2001a). The studies in 2003 involved mobile hydroacoustics (Faber et al. 2005) and radio telemetry. Two studies in 2004 examined locations of juvenile salmonids tagged with radio or acoustic transmitters (Hansel et al. 2005 and Cash et al. 2005, respectively). There was also a radio telemetry study in 2005 (Hansel et al. 2007). The 2003-2005 effort supported development of a Behavioral Guidance Structure (on hold at the time of this report) and, in general, understanding of passage patterns at the dam. These data addressed forebay approach patterns and residence times.

\subsubsection{Approach Patterns}

Radio telemetry research in the forebay was part of ongoing passage and survival studies and as such had sample sizes of approximately 1,500 to 2,000 tagged Chinook salmon in the spring (yearling fish) and similar numbers in summer (subyearling fish). These data provided insight on the approach of fish along a transect of receiving antennas across the reservoir at about MU 18, as well as the fate of the tagged fish (i.e., route of passage). The data from fish implanted with acoustic transmitters were based on groups of 75 to 366 juvenile salmonids representing several species. The data provided three-dimensional fish positions during approach and passage within about 450 to $650 \mathrm{ft}$ of the dam, depending on the hydrophone array in a given area. Behaviors of the tagged fish determined from the radio and acoustic telemetry studies were generally similar.

Data from radio-tagged fish indicated they approached along two primary routes as they entered the forebay. Approach path was ascertained by dividing into four groups fish detected along a transect composed of a series of aerial antennas spanning the river near MU 18. Aerial antennas were positioned at the north shore, the north side of a mid-river barge (BN), the barge's south side (BS), and the south shore (SS). The BN location was near the downstream side of Big Eddy (see bathymetry in Figure 2.1; Big Eddy is the deep area in the forebay off the east end of the powerhouse). During 2004, the highest numbers of detections of tagged fish were at BN and SS (Figure 3.1). During 2005, the primary detection areas were at BS and SS; this was true in both spring and summer and varied little by diel period (day or night). 


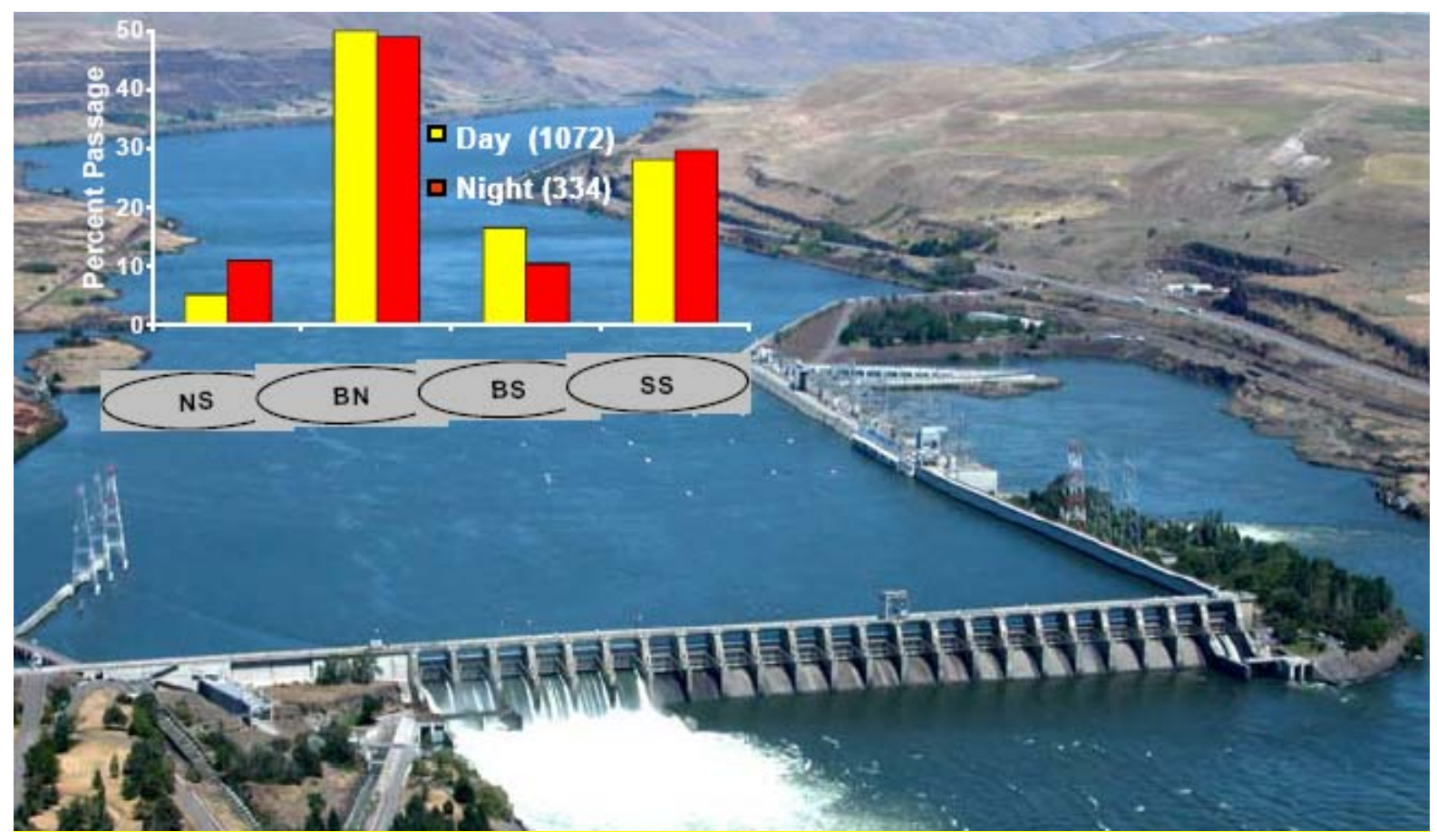

Figure 3.1. Passage Proportions of Radio-Tagged Yearling Chinook Salmon during Spring 2004. Ovals indicate approximate locations of detection areas along a transect near MU 18. Numbers indicate sample sizes during day and night. (Provided by USGS, Cook, Washington.)

Dam passage approach distributions were affected by the location of forebay approach (entrance) and diel period. Fish passing in more southerly locations had higher turbine passage overall, and this was most prevalent at night (Figure 3.2). For example, in 2004 non-turbine passage of yearling Chinook salmon in the SS group was $97.7 \%$ (95\% confidence interval [CI] 90.7\% to 99.8\%) during the day and $72.0 \%$ (CI 52.8\% to $86.9 \%$ ) during the night (Hansel et al. 2005). Yearling Chinook salmon in the BN group had non-turbine passage of $98 \%$ (CI 96.3\% to $99.0 \%$ ) during the day and $86.6 \%$ (CI $82.5 \%$ to $90.0 \%$ ) at night. Most of the BN fish passing into turbines did so at the west-end units. 


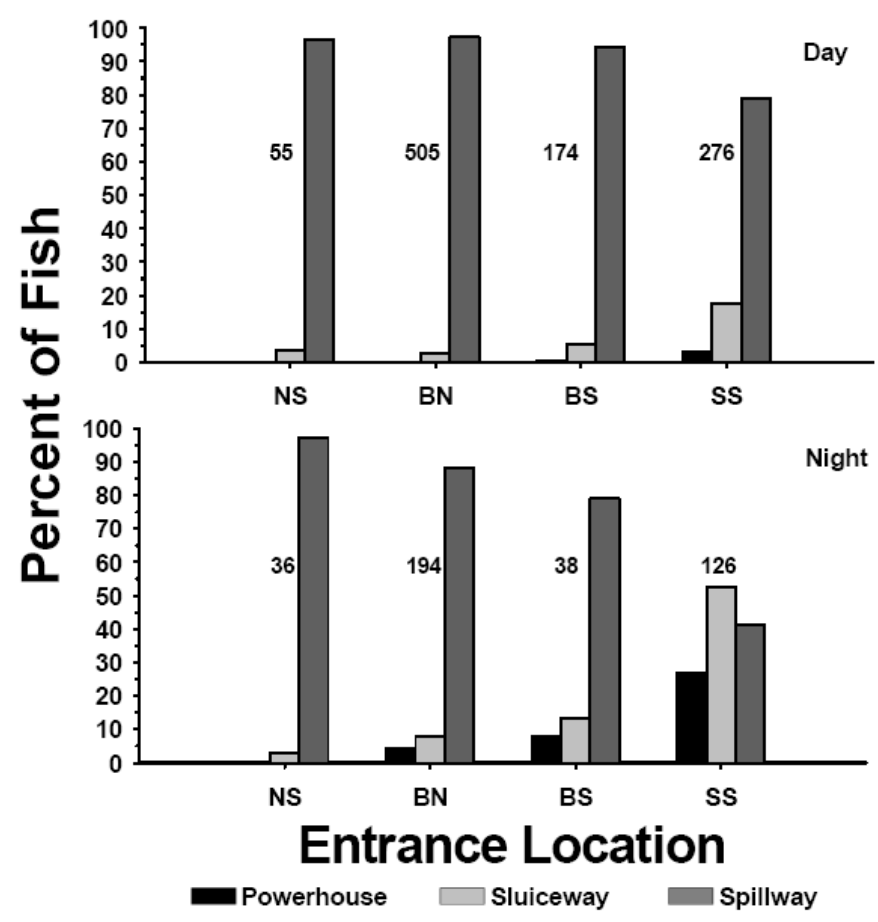

Figure 3.2. Forebay Approach Locations for Yearling Chinook Salmon at The Dalles Dam, April 28 through May 29, 2004. NS = north shore, $\mathrm{BN}=$ barge north, $\mathrm{BS}=$ barge south, $\mathrm{SS}=$ south shore. Day and night are 0530 to $2059 \mathrm{~h}$ and 2100 to $0529 \mathrm{~h}$, respectively. Sample sizes are shown near the bars. (From Hansel et al. 2005.)

Data from acoustic-tagged fish showed similar approach paths to those of radio-tagged fish, but provided additional detail on their vertical and horizontal positions throughout the forebay. Most fish approached the forebay through Big Eddy, where they generally took one of two routes: straight downstream toward the spillway or southerly toward the powerhouse (see Figure 3.3 for yearling Chinook salmon example; Cash et al. 2005). Diel differences in this pattern were more pronounced in juvenile Chinook salmon than in juvenile steelhead. Approximately $75 \%-85 \%$ of yearling Chinook salmon took the path toward the powerhouse during the day and about $25 \%-45 \%$ did so at night. The pathway proportions of subyearling Chinook salmon were similar to those of yearling Chinook salmon.

Fish depths during their approach to the dam varied by species and diel period. Data from the acoustic-tagged fish showed yearling and subyearling Chinook salmon were deeper during the day than at night and juvenile steelhead were shallower in the day than at night (Cash et al. 2005). During the day $60 \%-90 \%$ of Chinook salmon were deeper than $20 \mathrm{ft}$ during the day and at night about the same percentage was shallower than $20 \mathrm{ft}$. Juvenile steelhead were between 0 and $20 \mathrm{ft}$ during the day and between 0 and $65 \mathrm{ft}$ at night. 

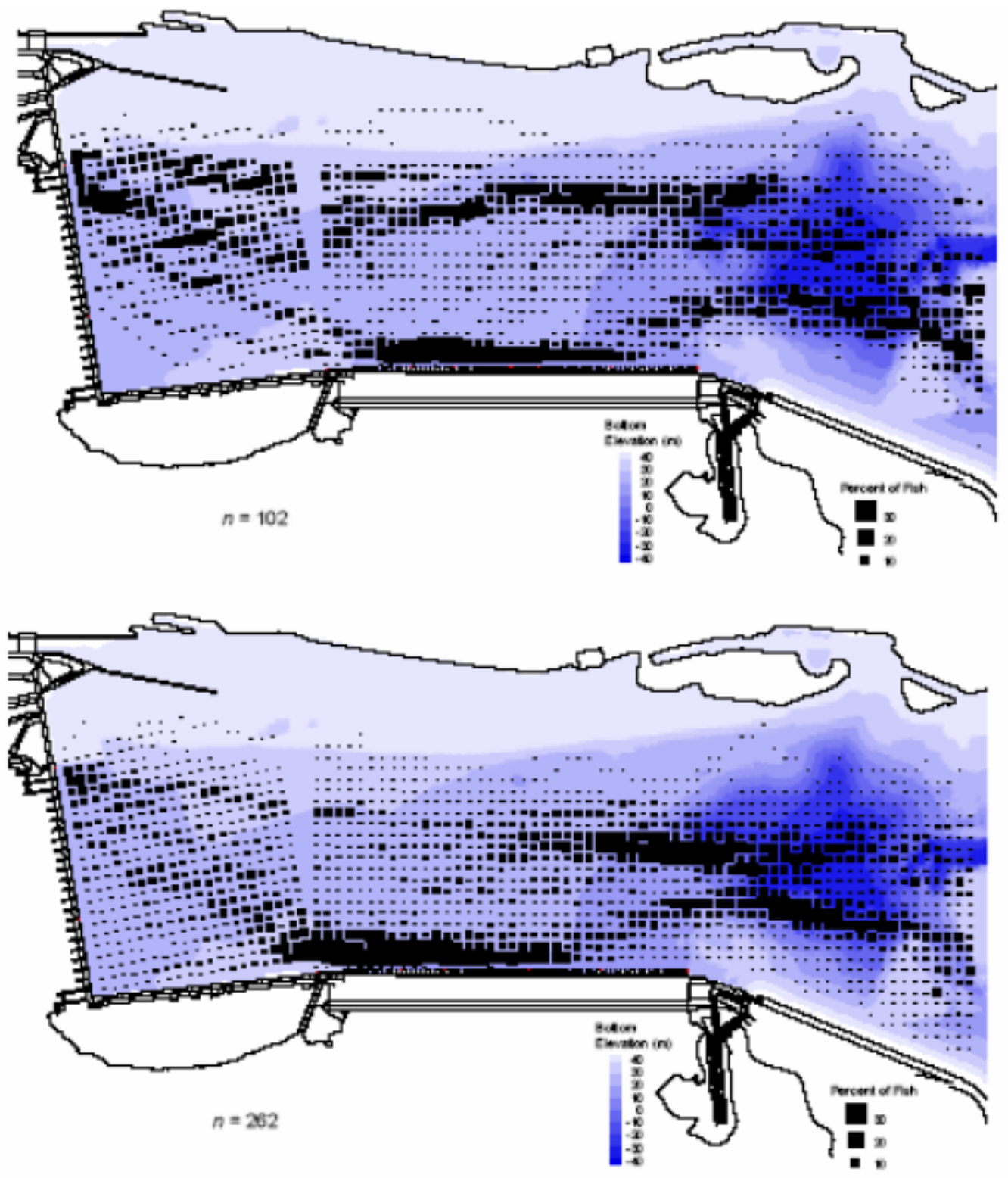

Figure 3.3. Horizontal Distributions of Acoustic-Tagged Yearling Chinook Salmon in the Forebay of The Dalles Dam. Data are for day (0530 to $2059 \mathrm{~h}$; upper plate) and night (2100to 0529 h; lower plate) from April 29 to June 7, 2004. (From Cash et al. 2005.)

The proportion of fish passing the spillway varied by location in the forebay, diel period, and species. Plots of the volumetric spill passage efficiency indicated juvenile steelhead and Chinook salmon throughout much of the forebay area passed via the spillway during the day, but this area was reduced at night (Figure 3.4). Tagged fish in the area in front of the powerhouse had much less spillway passage during the night than during the day, and many fish in this area passed via the turbines at night (Cash et al. 2005). This was more pronounced in juvenile steelhead and yearling Chinook salmon than in subyearling Chinook salmon. 

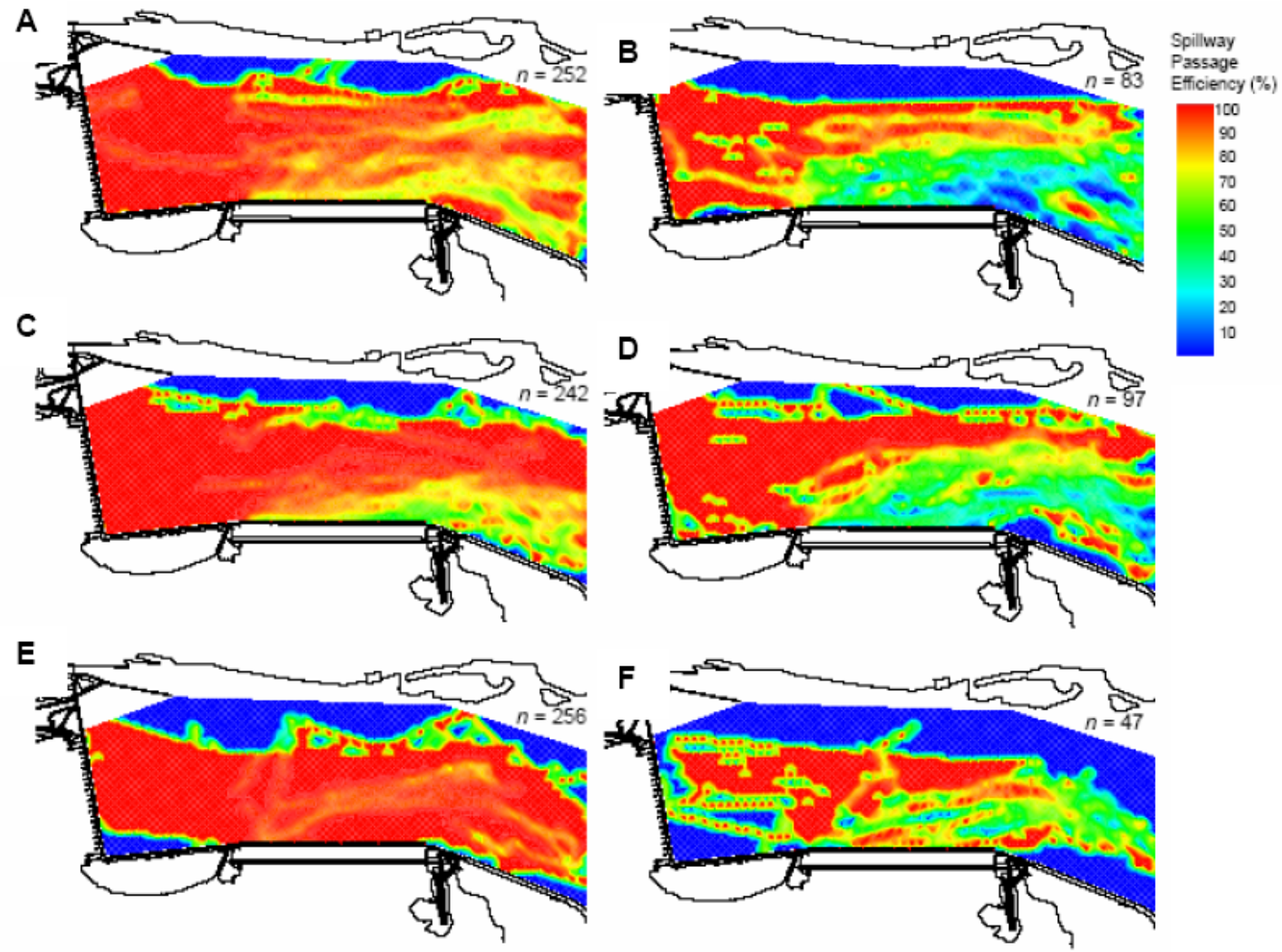

Figure 3.4. Plan Views of Volumetric Spillway Passage Efficiency of Hatchery Steelhead (A, B), Yearling Chinook Salmon (C, D), and Subyearling Chinook Salmon (E, F) during 2004 at The Dalles Dam. Plates on the left represent day (0530 to $2059 \mathrm{~h})$ and those on the right represent night $(2100$ to $0529 \mathrm{~h})$. Passage efficiency was calculated by the number of fish passing through a specific bin and subsequently passing through the spillway as a percentage of the total fish detected in that bin. (From Cash et al. 2005.)

\subsubsection{Residence Times}

In The Dalles Dam forebay, tagged fish have very short residence times (fractions of an hour) relative to other Columbia and Snake river dams. Most residence time data are from studies of radiotagged fish where researchers generally measured time from the first detection on aerial antennas to the time of last detection. The aerial antennas generally have a range of approximately $330 \mathrm{ft}$ from the dam. The configuration of The Dalles Dam could result in some bias in residence times using this method, because the powerhouse is farther upstream than the sluiceway and spillway. In addition, aerial antennas on the dam could not detect fish across the entire forebay, so some fish, such as those passing the spillway, could be in the "forebay" before they were detected. In 2003, 2004, and 2005, residence times of radio-tagged fish were calculated using the method with dam aerial antennas, as well as from the time of detection at a transect spanning the river near MU 18. The latter method resulted in longer residence times that were probably more representative of the true residence times of untagged fish. For example, the residence time of radio-tagged yearling Chinook salmon detected during the day in 2004 was 0.25 hours if based on aerial antennas at the dam and $0.54 \mathrm{~h}$ if based on 
the transect. Residence times based on aerial antennas at the dam and forebay barge are reported in Appendix B.

Median residence times in the forebay were affected by the presence of spill, but varied little among species. Median residence times of juvenile steelhead, yearling Chinook salmon, and subyearling Chinook salmon based on aerial antennas on the dam were generally less than $0.5 \mathrm{~h}$ when spill was present (Appendix B). In the absence of spill (2001 only), residence times of juvenile steelhead and yearling Chinook salmon were 2.0 to 4.3 times greater than when $30 \%$ spill was present. Data from other groups are not available without spill in 2001. The median residence times of fish implanted with acoustic tags in 2004 ranged from 0.6 to $0.9 \mathrm{~h}$ (Cash et al. 2005). Data from that study included the only data for sockeye salmon in this forebay and indicated a median residence time of $0.6 \mathrm{~h}$.

Forebay residence times vary by route of passage and time of passage, though the differences are small due to the short overall time fish spend in the forebay. Means of annual median residence times from MU 18 to the time of dam passage ranged from 0.25 to $1.04 \mathrm{~h}$, depending on passage route and diel period (Table 3.1). Residence times were shortest for fish passing via the turbines, intermediate for those passing via the sluiceway, and longest for those passing via the spillway. This relation is somewhat intuitive, given the order in which the routes are encountered.

Table 3.1. Means of Median Forebay Residence Times (h) from 2003, 2004, and 2005 Studies of Radio-Tagged Fish. Residence time was measured from the first detection at the transect near MU 18 (see Figure 3.1) to the last known location in the forebay.

\begin{tabular}{cccccc}
\hline Species & Period & Powerhouse & Sluiceway & Spillway & Overall \\
\hline CH1 & Day & 0.25 & 0.36 & 0.69 & 0.57 \\
CH1 & Night & 0.25 & 0.45 & 0.83 & 0.68 \\
CH1 & Overall & 0.44 & 0.39 & 0.69 & 0.60 \\
CH0 & Day & 0.29 & 0.44 & 0.64 & 0.62 \\
CH0 & Night & 0.34 & 0.54 & 1.04 & 0.81 \\
CH0 & Overall & 0.32 & 0.46 & 0.72 & 0.65 \\
\hline
\end{tabular}

Data from radio-tagged fish in 2005 were examined for this report using time-to-event analysis methods to examine the relationship between forebay residence times, passage route, and diel period (Hosmer and Lemeshow 1999). The time in the forebay was measured from first detection at the transect line crossing the river near MU 18 (as depicted in Figure 3.1) to the last known location in the forebay. The median residence times of yearling Chinook salmon were shortest for fish passing via the turbines $(0.28 \mathrm{~h})$, intermediate for those passing via the sluiceway $(0.43 \mathrm{~h})$, and longest for those passing the spillway $(0.78 \mathrm{~h})$. Data from subyearling Chinook salmon were similar, with median residence times of $0.32,0.54$, and $0.71 \mathrm{~h}$ for fish passing via the turbines, sluiceway, and spillway, respectively. Plots of the Kaplan-Meier survival distribution function clearly show this relation (Figure 3.5 upper plates). The survival distribution function in these analyses is a measure of the proportion of fish that remain in the forebay (given no censoring), not survival as we generally think of it. As such, the median forebay residence time is the time at which the survival distribution function is 0.5 (Figure 3.5). The time of passage also affected forebay residence times, with the shortest times occurring during the day (Figure 3.5, lower plates). Overall (all routes pooled) median forebay residence times of yearling Chinook salmon were $0.65 \mathrm{~h}$ during the day and $0.79 \mathrm{~h}$ at night. 
Times for subyearling Chinook salmon were $0.60 \mathrm{~h}$ during the day and $0.84 \mathrm{~h}$ at night. Regression analyses based on the proportional-hazards model indicate the diel differences are due to greater discharge in the day than during the night (data not shown).
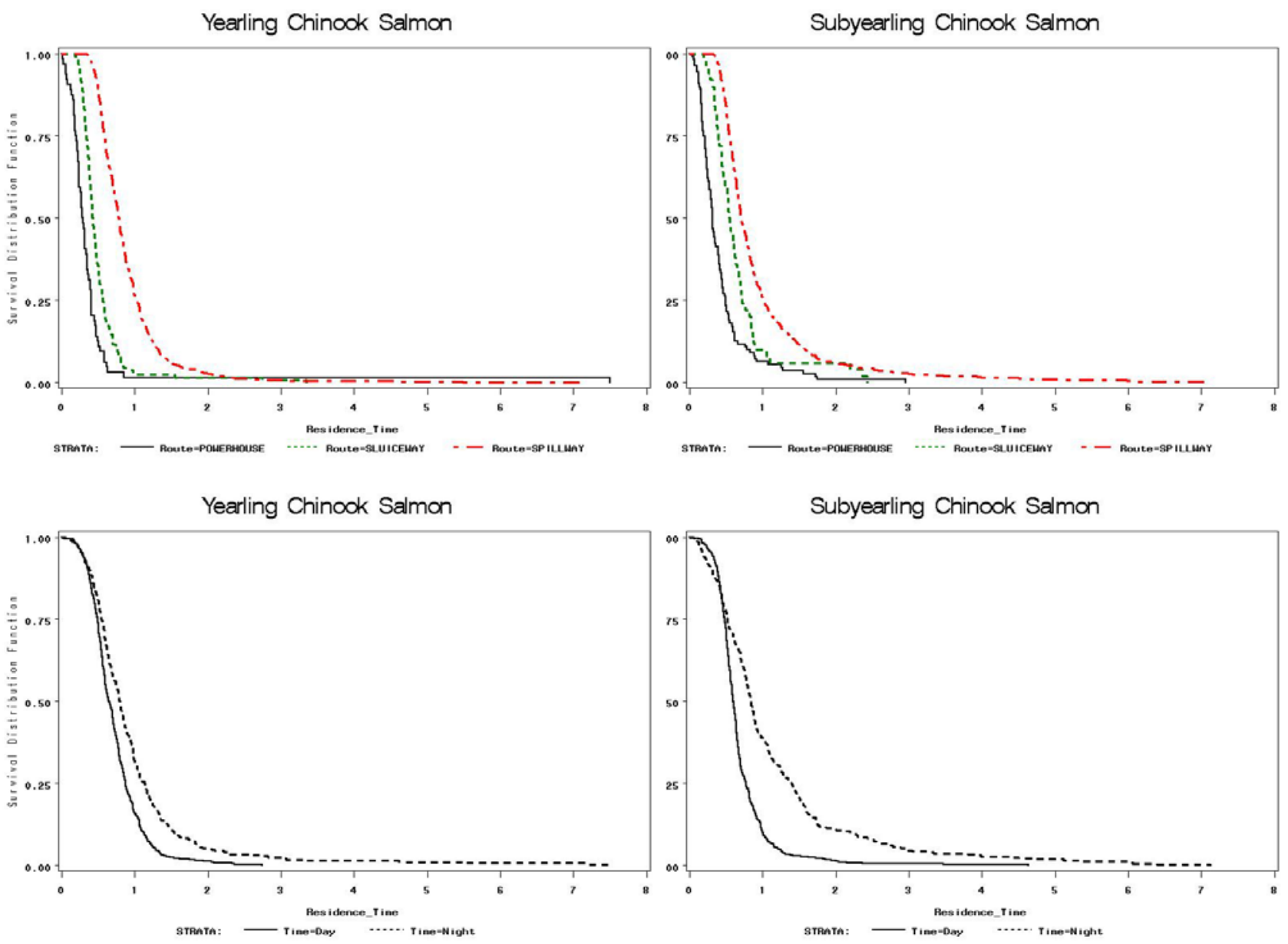

Figure 3.5. Kaplan-Meier Survival Distribution Functions of the Forebay Residence Time (h) of Radio-Tagged Yearling and Subyearling Chinook Salmon in 2005

The survival distribution function represents the proportion of fish remaining in the forebay at each time point and does not relate to survival estimates in Section 7. Day and night periods were passage times divided at sunrise and sunset on each day of analysis. Data were from fish described in Hansel et al. (2007). One yearling Chinook salmon with a residence time of $24 \mathrm{~h}$ was omitted from this analysis.

\subsection{Passage Efficiencies}

The driver for the fish passage efficiency studies was total project survival estimates for juvenile salmonids, which require passage proportions for each route (turbine, sluiceway, and spillway). Fish passage and survival studies occurred every year during 2001-2005 (Table 1.1). Results for these metrics are presented in this report when data are sufficient to provide usable estimates. Definitions for these key variables follow. 
- Fish Passage Efficiency (FPE) - the proportion of fish that pass through non-turbine routes, i.e., sluiceway and spillway, out of total project passage.

- Spill Passage Efficiency (SPY) - the proportion that pass through the spillway out of total project passage.

- Sluice Passage Efficiency (SLY) - the proportion that pass through the sluiceway out of total project passage.

- Turbine Passage Efficiency - the proportion that pass through the turbines out of total project passage.

- Spill Passage Effectiveness - SPY divided by percent of total project discharge going over the spillway.

- $\quad$ Sluice Passage Effectiveness - SLY divided by the proportion of total project discharge passing through the sluiceway.

Studies were conducted to determine the effects of various structural and operational modifications on fish passage proportions and survival through the spillway, ice-trash sluiceway, and turbines. Several changes in project operation occurred during the 2001-2005 time period. In 2001, river discharge was low (47\% of the April 1-August 1, 10-year average), and the use of spill was intermittent during the spring and absent during the summer. These conditions provided the only data of fish passage in the absence of spill available for the 2001-2005 time period. In 2001 and 2002, the effects of occlusion plates partially blocking the turbine intakes of MU 1-5 were evaluated using radio telemetry and fixed hydroacoustics (see Section 6). As part of the evaluations in 2002, the powerhouse was block-loaded on the west side so the main units with the devices would be used as much as possible. Changes in the number and locations of openings to the sluiceway were made in 2004 and 2005 (see Section 5). Lastly, the spill pattern was concentrated more to the northern six spill bays after a new spillwall was constructed during winter $2003 / 2004$. Spill was near $30 \%$ during a limited amount of time in 2001, but was fairly consistent between $35 \%$ and $40 \%$ during the 20022005 fish spill periods. Therefore, we combined 2002-2005 data, but not 2001, in the passage efficiency analyses that follow. Data for each study year separately are presented in Appendix C.

\subsubsection{Passage Efficiency Estimates from Radio and Acoustic Telemetry}

The proportions of juvenile salmonids passing various routes at The Dalles Dam (passage efficiency and effectiveness) vary by species and time of day. This section primarily describes passage of radio-tagged yearling Chinook salmon, juvenile steelhead, and subyearling Chinook salmon. A study of acoustic-tagged juvenile salmonids was also conducted in 2004 (Cash et al. 2005). Data from Cash et al. (2005) are included in Table 3.2 and Appendix C where applicable. The following narrative describes passage efficiencies from studies in 2001-2005.

Route-specific passage proportions (passage efficiencies) of yearling Chinook salmon were estimated each year from 2001-2005. In the absence of spill in 2001, sluiceway passage was $85 \%$ during the day and $70 \%$ at night. With spill present at about $40 \%$ during $2002-2005$, average overall passage was primarily via the spillway (85\%) followed by the powerhouse $(15 \%)$ and sluiceway (12\%; Table 3.2). 
Table 3.2. Summary of Passage Efficiency and Effectiveness of Tagged Juvenile Salmonids at The Dalles Dam. Data from 2002-2005 are averages of the data in Appendix C. Data from 2004 was averaged over radio and acoustic studies. ${ }^{1}=2004$ only, ${ }^{2}=2002$ and 2004 only, ${ }^{3}=2003-2005$ only, $*=$ midpoint of range provided in Cash et al. (2005). NR $=$ not reported, $\mathrm{NA}=$ not applicable.

\begin{tabular}{|c|c|c|c|c|c|c|c|c|c|c|}
\hline \multirow[b]{2}{*}{ Species } & \multirow[b]{2}{*}{ Treatment } & \multirow[b]{2}{*}{$\mathrm{N}$} & \multicolumn{4}{|c|}{ Efficiency (\%) } & \multicolumn{2}{|c|}{ Effectiveness } & \multirow{2}{*}{$\begin{array}{c}\text { Avg } \\
\% \\
\text { Spill }\end{array}$} & \multirow{2}{*}{$\begin{array}{c}\text { Mean } \\
\text { total } \\
\text { kcfs }\end{array}$} \\
\hline & & & Turbine & Sluice & Spillway & FPE & Sluiceway & Spillway & & \\
\hline \multicolumn{11}{|c|}{2001 (Beeman et al. 2005) } \\
\hline \multirow[t]{4}{*}{ STH } & Day spill & 191 & 5.1 & 24.4 & 70.5 & 94.9 & $8.4: 1$ & $2.3: 1$ & 30.7 & 149 \\
\hline & $\begin{array}{l}\text { Day no } \\
\text { spill }\end{array}$ & 74 & 10.6 & 89.4 & NA & 89.4 & 26.3:1 & NA & 0 & 125 \\
\hline & Nightspill & 184 & 14.4 & 23.9 & 61.7 & 85.6 & $7.5: 1$ & $2.0: 1$ & 30.2 & 135 \\
\hline & $\begin{array}{c}\text { Night no } \\
\text { spill }\end{array}$ & 117 & 33.9 & 66.1 & NA & 66.1 & $16.5: 1$ & NA & 0 & 106 \\
\hline \multirow[t]{4}{*}{$\mathrm{CH} 1$} & Day spill & 235 & 4.1 & 11.1 & 84.7 & 95.9 & $3.8: 1$ & $2.8: 1$ & 30.7 & 149 \\
\hline & $\begin{array}{l}\text { Day no } \\
\text { spill }\end{array}$ & 78 & 16.1 & 83.9 & NA & 83.9 & $24.7: 1$ & NA & 0 & 125 \\
\hline & $\begin{array}{l}\text { Night } \\
\text { spill }\end{array}$ & 139 & 9.3 & 23.1 & 67.5 & 90.7 & $7.2: 1$ & $2: 2.1$ & 30.2 & 135 \\
\hline & $\begin{array}{l}\text { Night no } \\
\text { spill }\end{array}$ & 81 & 29.9 & 70.1 & NA & 70.1 & $17.5: 1$ & NA & 0 & 106 \\
\hline \multirow[t]{2}{*}{$\mathrm{CHO}$} & $\begin{array}{l}\text { Day no } \\
\text { spill }\end{array}$ & 381 & 61.7 & 38.3 & NA & 38.3 & $9.8: 1$ & NA & 0 & 110 \\
\hline & $\begin{array}{l}\text { Night no } \\
\text { spill }\end{array}$ & 322 & 69.6 & 30.4 & NA & 30.4 & $6.6: 1$ & NA & 0 & 93 \\
\hline \multicolumn{11}{|c|}{ 2002-2005 (Hausman et al. 2004; Hansel et al. 2004, 2005, 2007; Cash et al. 2005) } \\
\hline \multirow[t]{3}{*}{ STH } & Day $^{1}$ & NA & 2.3 & 7.8 & 88.9 & 96.7 & $3.5: 1$ & $2.2: 1$ & 40.0 & $205.4^{*}$ \\
\hline & Night $^{1}$ & NA & 30.0 & 10.0 & 60.0 & 70.0 & $4.5: 1$ & $1.5: 1$ & 40.0 & $205.4^{*}$ \\
\hline & Overall $^{2}$ & NA & 10.0 & 11.2 & 78.9 & 90.1 & $6.6: 1$ & $2.0: 1$ & 39.0 & 228.2 \\
\hline \multirow[t]{3}{*}{$\mathrm{CH} 1$} & $\mathrm{Day}^{3}$ & NA & 5.7 & 12.1 & 82.2 & 94.3 & $3.3: 1$ & $2.2: 1$ & 37.8 & 224.1 \\
\hline & $\mathrm{Night}^{3}$ & NA & 21.4 & 13.0 & 65.6 & 78.6 & $4.7: 1$ & $1.7: 1$ & 38.5 & 210.7 \\
\hline & Overall & NA & 15.2 & 11.8 & 73.0 & 84.8 & 7.1:1 & 1.9:1 & 38.1 & 227.3 \\
\hline \multirow[t]{3}{*}{$\mathrm{CHO}$} & Day $^{3}$ & NA & 6.9 & 5.9 & 87.3 & 93.1 & $1.2: 1$ & $2.2: 1$ & 39.2 & 174.9 \\
\hline & Night $^{3}$ & NA & 27.4 & 8.2 & 64.4 & 72.6 & $1.9: 1$ & $1.6: 1$ & 40.7 & 157.1 \\
\hline & Overall & NA & 18.7 & 7.0 & 74.4 & 81.3 & $4.3: 1$ & $1.9: 1$ & 39.1 & 193.7 \\
\hline \multirow[t]{3}{*}{$\mathrm{SOC}$} & Day $^{1}$ & NA & 0 & 1.8 & 98.2 & 100.0 & $0.8: 1$ & $2.4: 1$ & 40.0 & $205.4^{*}$ \\
\hline & Night $^{1}$ & NA & 12.5 & 12.5 & 75.0 & 87.5 & $5.7: 1$ & 1.9:1 & 40.0 & $205.4^{*}$ \\
\hline & Overal $^{1}$ & $\mathrm{NA}$ & 1.6 & 3.2 & 95.2 & 98.4 & $0.7: 1$ & $2.4: 1$ & 40.0 & $205.4^{*}$ \\
\hline
\end{tabular}

Passage efficiencies for juvenile steelhead were studied in 2001, 2002, and 2004. Non-turbine steelhead passage was slightly greater than that of yearling Chinook salmon, but route-specific 
passage proportions follow trends similar to those of yearling Chinook salmon. The overall turbine passage of juvenile steelhead in 2002 was $10 \%$, approximately one-third that of yearling Chinook salmon (Table 3.2). In the absence of spill in 2001, sluiceway passage efficiency was $90 \%$ during the day and $66 \%$ at night. During spill in 2001, the estimates of sluiceway passage efficiency were $24 \%$ in both the day and the night. Juvenile steelhead tagged with acoustic transmitters were studied in 2004. Their passage proportions were similar to those of acoustic-tagged yearling Chinook salmon in that year (Appendix C).

Passage of subyearling Chinook salmon was studied in 2001-2005. They have greater turbine passage rates than the other species that were studied. Average turbine passage efficiency from estimates in 2002-2005 was $19 \%$ (Table 3.2). Among years, turbine passage ranged from $23 \%-29 \%$ at night and from 5\%-11\% during the day in 2003-2005 (Appendix C). In the absence of spill in 2001 , turbine passage efficiency was $70 \%$ at night and $62 \%$ during the day, and by subtraction from $100 \%$, sluiceway passage was $30 \%$ at night and $38 \%$ during the day. Sluiceway passage ranged from $8 \%-12 \%$ in $2002-2005$.

Passage effectiveness is generally inversely proportional to the volume of water associated with a route. Thus, passage effectiveness of the sluiceway is greater than that of the spillway (Table 3.2). Average annual effectiveness of the sluiceway for juvenile steelhead and Chinook salmon ranged from 1.2 to 6.6 depending on species and time of day (day or night). Average annual spillway effectiveness ranged from 1.6 to 2.2.

Juvenile sockeye implanted with acoustic transmitters were studied in 2004. A total of 62 fish were tagged and released. Their FPE was $100 \%$ during the day and $87.5 \%$ at night, for a weightedaverage of $92.2 \%$ (Table 3.2). Sluiceway effectiveness of acoustic-tagged sockeye in 2004 was 0.8 in the day and 5.7 at night. Their spillway effectiveness was 2.4 during the day and 1.9 at night.

Passage efficiency estimates from fish implanted with radio or acoustic transmitters in 2004 were similar in the spring, but disparate during the summer. Estimates of yearling Chinook salmon SLY, SPY, and FPE from the two studies are nearly identical (Appendix C). Those of subyearling Chinook salmon indicate greater SLY, lower SPY, and lower FPE from radio-tagged fish than from acoustictagged fish. For example, the SLY of radio-tagged subyearling Chinook salmon during the day was $6.7 \%$ (CI 5.4\% to 8.8\%); for acoustic-tagged fish it was 1.2\% (no confidence bounds available). The reasons for these differences are unknown, but could include differences in tagging methods, sample sizes, or detection methods.

\subsubsection{Passage Efficiency Estimates from Hydroacoustics}

Fish passage metrics for fixed-location hydroacoustic studies conducted at The Dalles Dam during 2001-2005 are summarized in Table 3.3. The data were quite variable among the study years, especially during summer. Fish passage efficiency ranged from $69 \%$ to $91 \%$ during spring periods, but was 14 to $82 \%$ during summer periods. Spill passage efficiency mirrored FPE and was noticeably low at $45 \%$ during spring 2002. Sluice passage efficiency (relative to the total project) was highest at $25 \%$ during spring 2002 and lowest at 4\% during summer 2004. Spill effectiveness ranged from 1.03 to 3.78 while sluice effectiveness ranged from 1.36 to 12.96. As discussed in Section 8, these data reflect dam operations and river discharge conditions during the respective studies. 
Table 3.3. Passage Efficiency and Effectiveness for the Run-at-Large at The Dalles Dam from Hydroacoustic Studies during 2001-2005. Hydroacoustic studies of passage efficiency and effectiveness were not conducted in 2003 or 2005.

\begin{tabular}{|c|c|c|c|c|c|c|c|c|}
\hline \multirow[b]{2}{*}{ Season } & \multirow[b]{2}{*}{ Year } & \multicolumn{4}{|c|}{ Efficiency (\%) } & \multicolumn{2}{|c|}{ Effectiveness } & \multirow[b]{2}{*}{ Source } \\
\hline & & Turbines & Sluiceway & Spillway & FPE & Sluiceway & Spillway & \\
\hline \multirow[t]{3}{*}{ Spring } & 2001 & 17 & 18 & 65 & 83 & 6.03 & 3.78 & $\begin{array}{c}\text { Moursund et } \\
\text { al. } 2002\end{array}$ \\
\hline & 2002 & 31 & 24 & 45 & 69 & 12.96 & 1.22 & $\begin{array}{c}\text { Johnson et al. } \\
2003\end{array}$ \\
\hline & 2004 & 9 & 7 & 84 & 91 & 3.25 & 2.13 & $\begin{array}{c}\text { Johnson et al. } \\
2005\end{array}$ \\
\hline \multirow[t]{3}{*}{ Summer } & 2001 & 06 & 5 & 9 & 14 & 1.36 & 2.89 & $\begin{array}{l}\text { Moursund et } \\
\text { al. } 2002\end{array}$ \\
\hline & 2002 & 50 & 12 & 38 & 50 & 7.62 & 1.03 & $\begin{array}{c}\text { Johnson et al. } \\
2003\end{array}$ \\
\hline & 2004 & 18 & 4 & 78 & 82 & 1.65 & 2.00 & $\begin{array}{c}\text { Johnson et al. } \\
2005\end{array}$ \\
\hline
\end{tabular}

\subsection{Passage Distributions}

\subsubsection{Horizontal}

The horizontal distribution of fish passage for the run-at-large at the powerhouse was skewed toward the western end of the structure during spring (Figure 3.6). This was largely due to relatively high passage rates at Sluice 1 above Main Unit 1. This pattern was consistent across 2002, 2004, and 2005. However, during summer, the horizontal distribution was more uniform across the powerhouse (Figure 3.6) with passage rates at eastern units higher during summer than spring.

At the spillway, the horizontal distribution during spring was skewed to the southern-most operating bays (Figure 3.6). For instance, during bulk spill at Bays 1-6 in 2004, passage rates were highest at Bay 6. During summer at the spillway, passage rates were variable.

Normalizing the turbine horizontal distribution data by turbine discharge (a variable we call density, which is fish passage per unit flow) showed that the eastern units had the highest fish densities during summer (Figure 3.7). Fish densities at the turbines were variable in spring. 

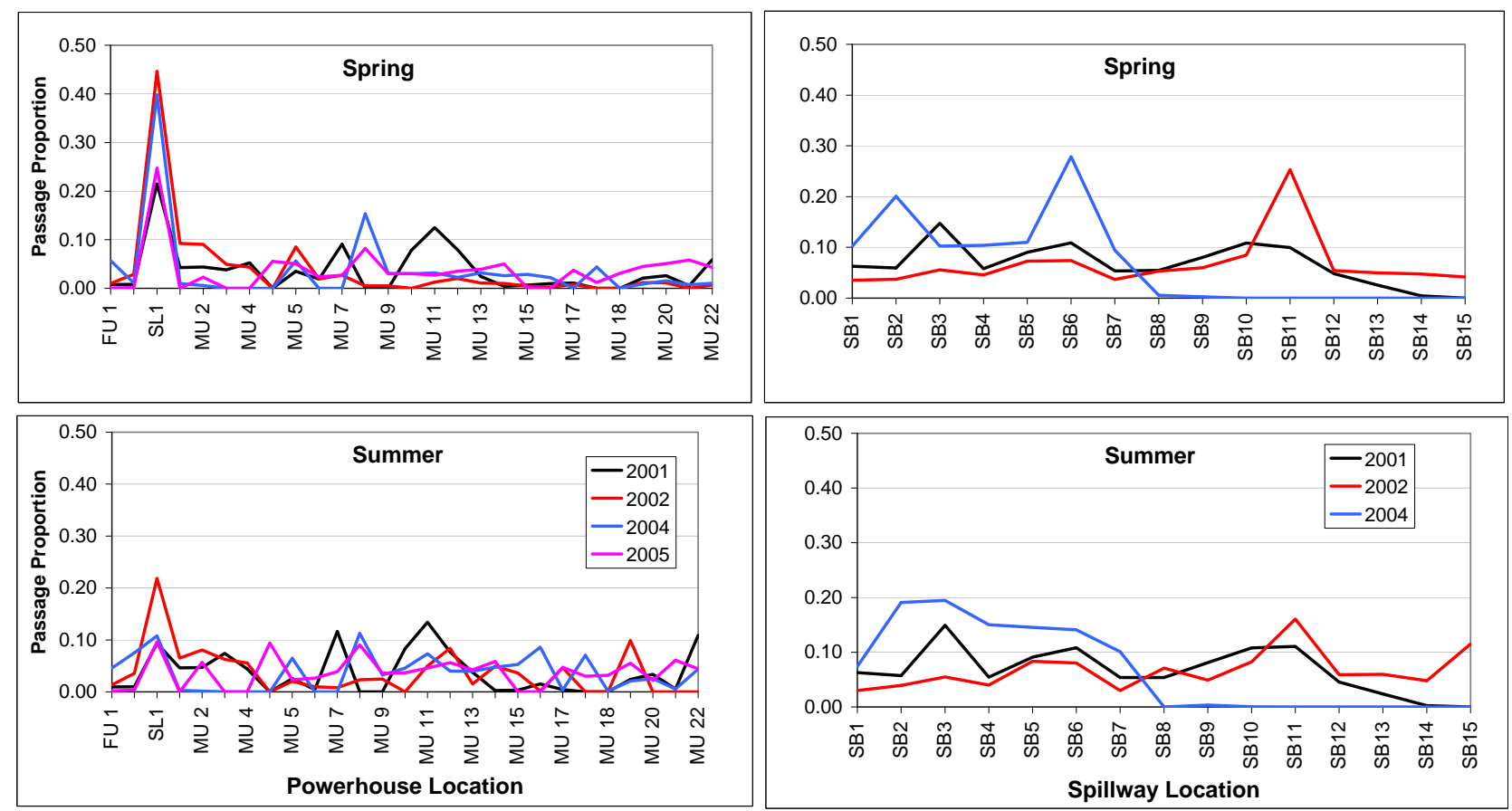

Figure 3.6. Horizontal Distribution of Fish Passage Proportions at the Turbines (left) and Spillway (right) at The Dalles Dam during Spring and Summer 2001-2005, except 2003. The spillway was not sampled with hydroacoustics in 2005. (Data are from hydroacoustic studies by Moursund et al. 2002; Johnson et al. 2003; 2005; and 2006.)
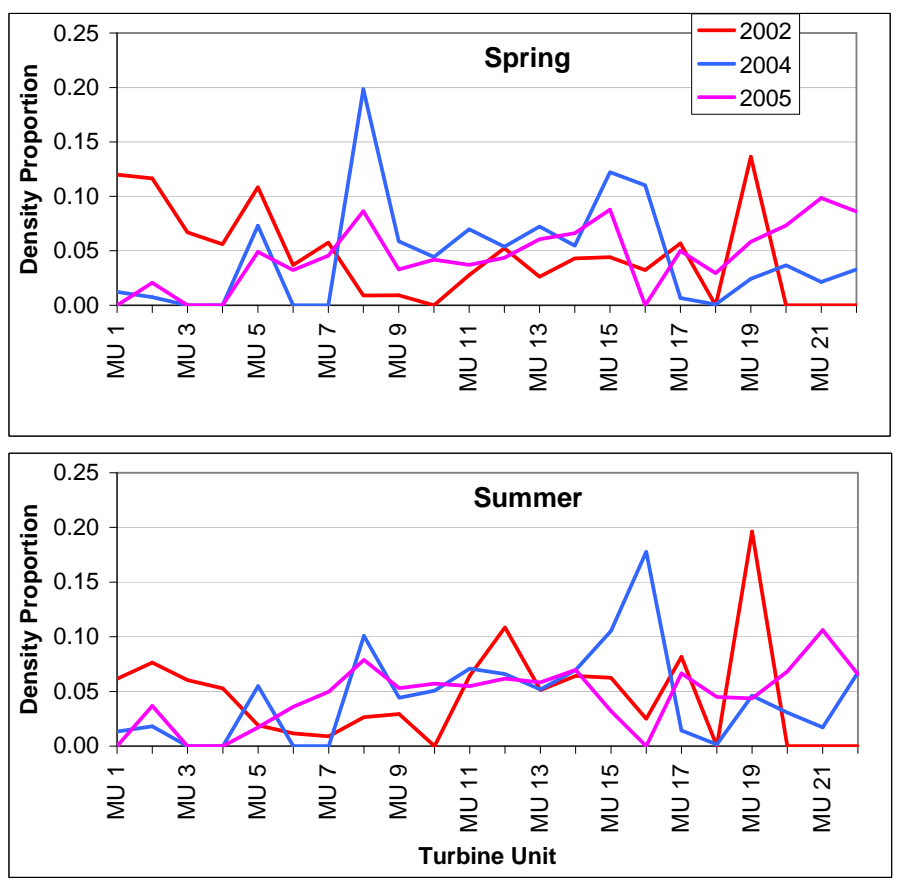

Figure 3.7. Horizontal Distribution of Fish Density (total fish passed per mean kcfs) Proportions at Turbines at The Dalles Dam during Spring (top) and Summer (bottom) 2002, 2004, and 2005. (Data are from hydroacoustic studies by Johnson et al. 2003; 2005; and 2006.) 


\subsubsection{Vertical}

The vertical distribution for the run-at-large from hydroacoustic sampling inside turbine intakes in 2004 and 2005 showed the typical skewing toward the intake ceiling (Figure 3.8). Turbine passage was somewhat deeper during night than day. These distributions are consistent with previous studies (Ploskey et al. 2001a). During summer, vertical distributions in-turbine were deeper in 2004 than 2005.

At the spillway immediately upstream of the Tainter gates where the hydroacoustic beams sample, the vertical distribution of fish peaked at depths 3-7 ft above the ogee during the 2004 study (Figure 3.9). The spillway vertical distribution was deeper during summer than spring 2004. Note that the hydroacoustic sampling location just upstream of the Tainter gates at the spillway means the vertical distribution data are influenced downward by spill at the ogee 35-50 ft deep. i.e., vertical distributions in the forebay proper may be higher in the water column.
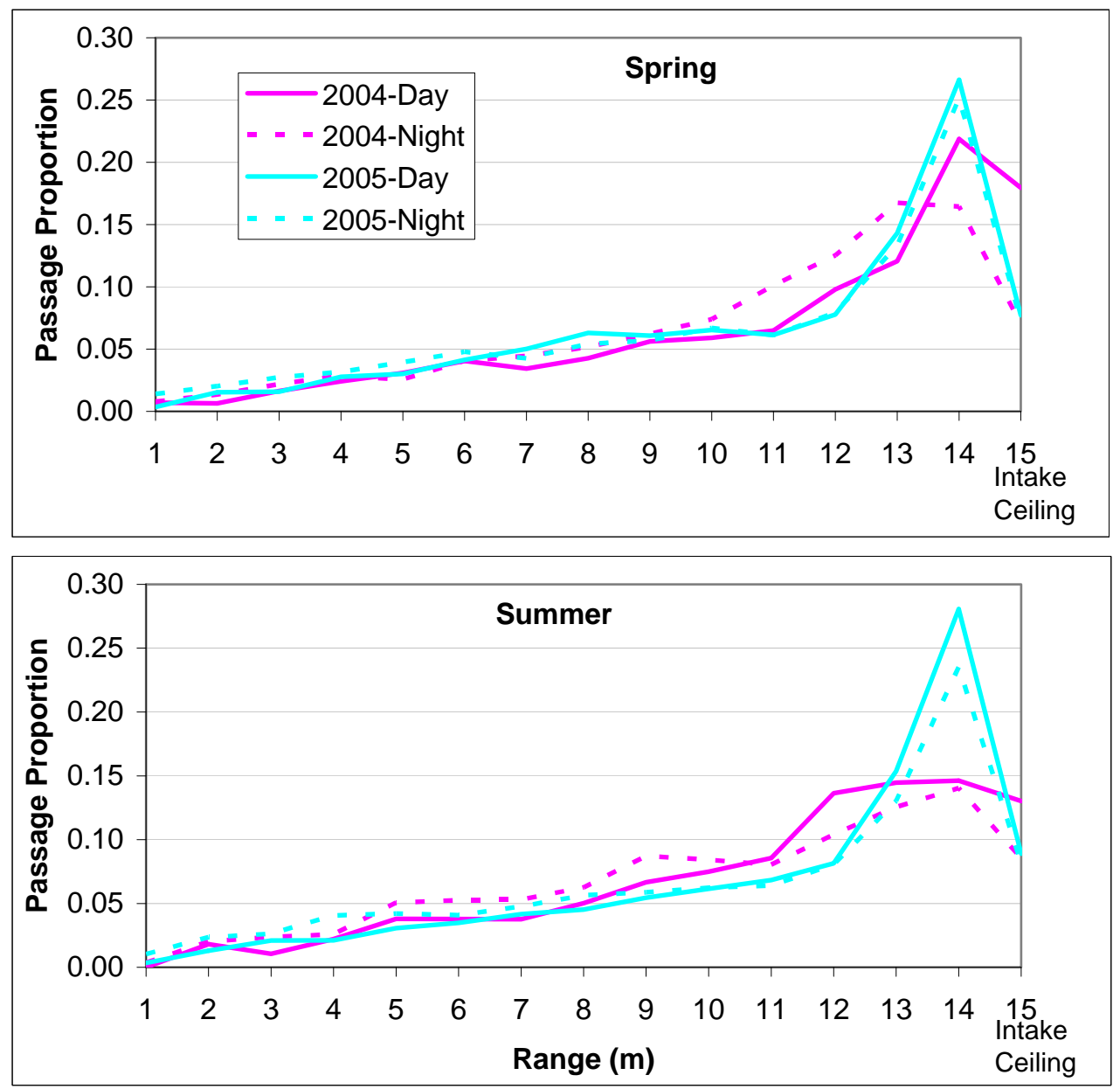

Figure 3.8. Vertical Distribution of Fish Passage Proportions at Turbines at The Dalles Dam during Spring (top) and Summer (bottom) 2004 and 2005. The 2002 data are not presented because of the presence of the J-occlusions during that study. (Data are from hydroacoustic studies by Johnson et al. 2005 and 2006.) 


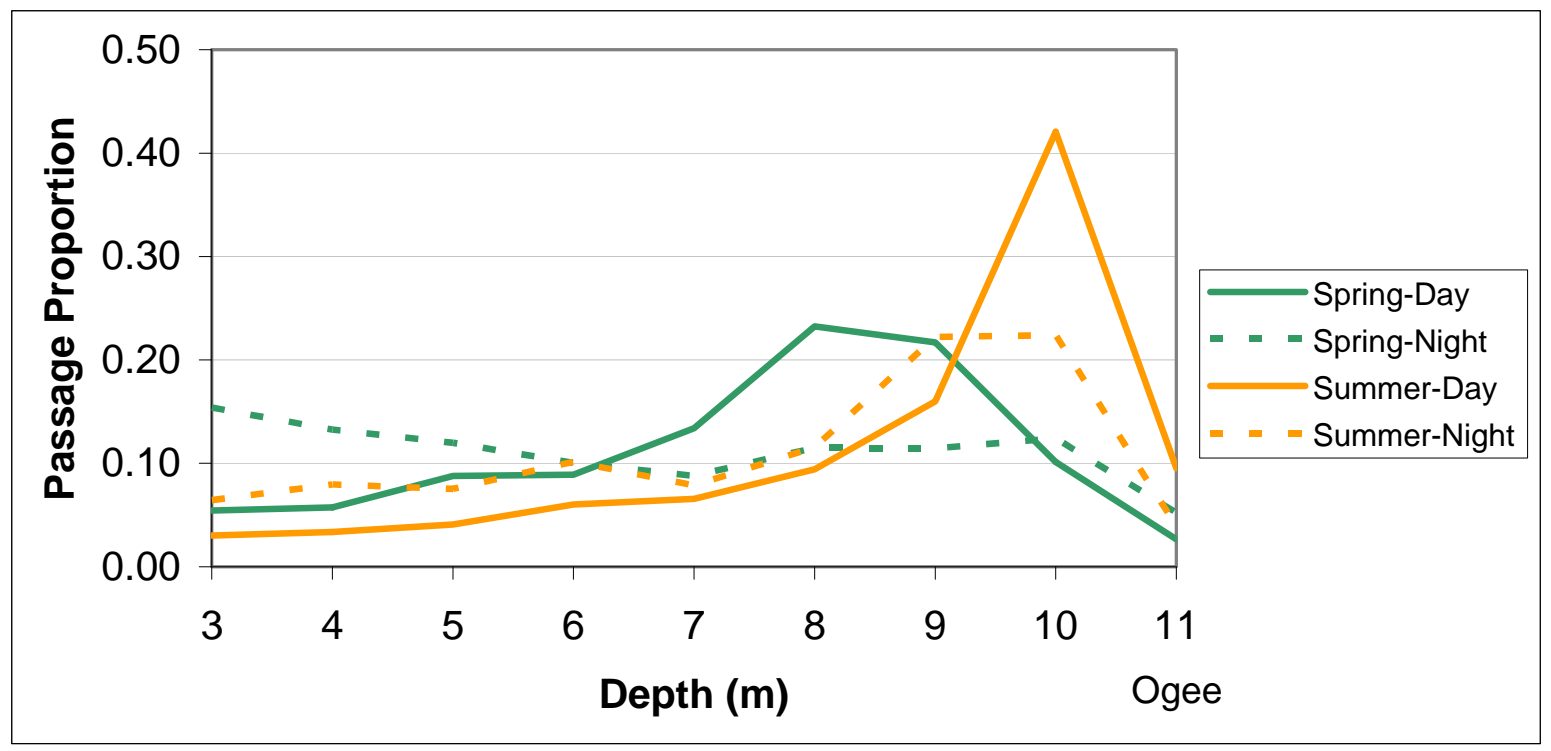

Figure 3.9. Vertical Distribution of Fish Passage Proportions at Spillway at The Dalles Dam during Spring and Summer 2004. (Data are from the hydroacoustic study by Johnson et al. 2005.)

\subsubsection{Diel}

From radio-telemetry data, diel passage estimates available in 2003-2005 showed average annual sluiceway passage of $6 \%$ during the day and $8 \%$ at night for yearling Chinook salmon. In the absence of spill in 2001 sluiceway passage was $30 \%$ at night and 38\% during the day. Diel differences in use of passage routes were evident with turbine passage greatest during the night and spillway passage greatest during the day (Figure 3.10).
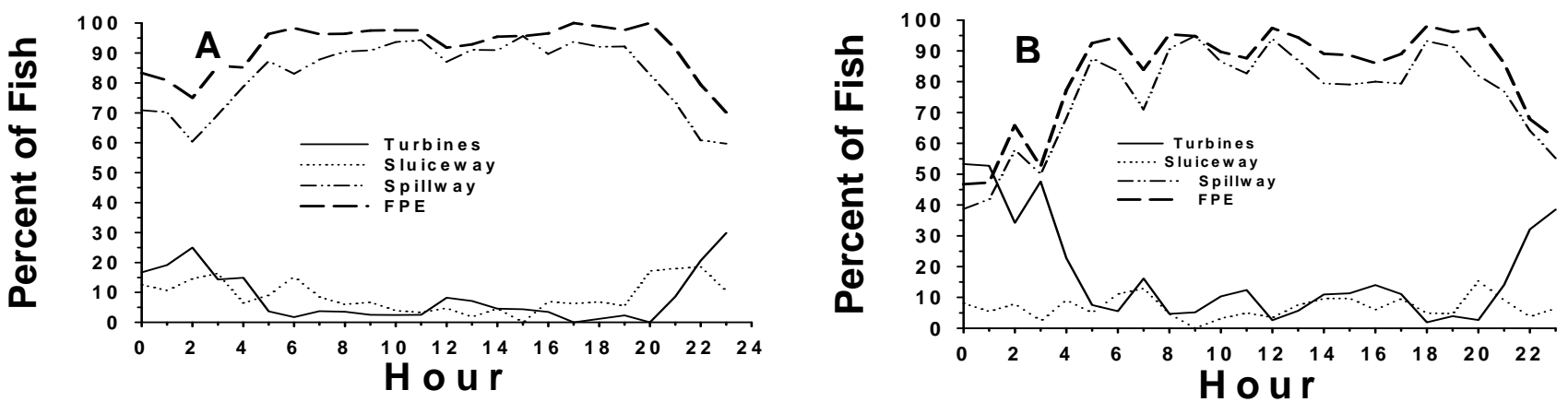

Figure 3.10. Diel Passage Distributions of Radio-Tagged Juvenile Chinook Salmon through the Main Routes at The Dalles Dam and Overall FPE during 2004. Data are from (A-left) 2,095 yearling Chinook salmon passing from April 28 - May 29 and (B-right) 1,848 subyearling Chinook salmon passing from June 19 - July 29. (Data are from Hansel et al. 2005.)

From hydroacoustic studies, we examined diel passage data for the turbines, sluiceway, and spillway for spring and summer separately during 2002, 2004, and 2005 (Figure 3.11). At the turbines, there was usually a crepuscular peak at dusk and dips in passage after dawn during both spring and summer. Sluiceway passage was uniform in 2004 and 2005, but showed crepuscular peaks 
at dawn and dusk in 2002. Diel passage at the spillway was variable with a tendency toward higher passage during day than night hours.
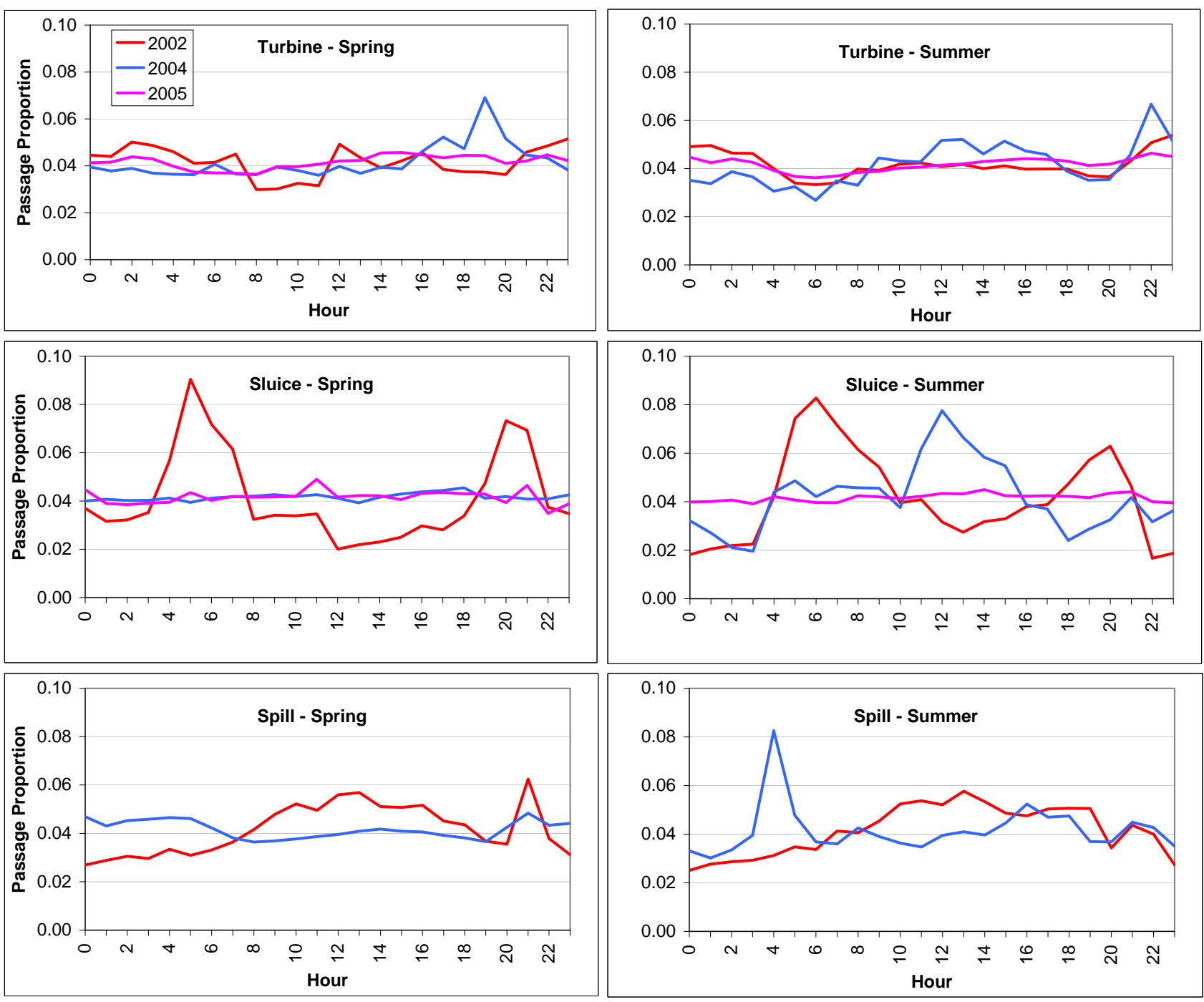

Figure 3.11. Diel Passage Distributions during Spring (left) and Summer (right) for Turbine, Sluice and Spill at The Dalles Dam. The spillway was not sampled in 2005. (Data are from hydroacoustic studies by Johnson et al. 2003; 2005; and 2006.)

\subsection{Forebay and Dam Hydraulics Research}

The 1:80 general physical model was the primary tool for evaluating flow conditions at The Dalles Dam, along with a 1:25 sectional model of an intake (upstream of the wicket gates). Both physical models are at the Engineering Research and Development Center (ERDC) in Vicksburg, Mississippi. The 1:25 sectional physical model, which is no longer functional, consisted of a turbine intake and walls that extended into the forebay at an angle to the intake structure. The angle of the walls could be adjusted depending upon the anticipated flow conditions into the unit. In addition, in 2000, a CFD model was developed of the forebay. Several CFD models have been built since 2000 but the latest model output is exemplified in Figure 3.12. Calibration data collected by ENSR 
(2001) were used to validate the CFD model. Hydraulic research performed to support specific fisheries engineering efforts revealed some important findings for hydrodynamic conditions in The Dalles Dam forebay.

Forebay water current patterns depend on total river discharge and powerhouse and spillway operations (Figure 3.12). Since the powerhouse is oriented parallel to the longitudinal axis of the Columbia River, flow into the powerhouse is at an oblique angle. Where the flow comes from is dependent on which units are operating and how many units are operating. Operations are typically set with every other unit operating starting with the west end and moving to the east. Once every other unit is operating the remaining units are added, starting at the west end.

Along the north shore, the bathymetry is extremely shallow and spill creates a north to south movement of flow as the river approaches the spillway. Two eddies develop at the spillway - one on the south side of the spillway along the non-overflow section and one on the north shore between bay 1 and the navigation lock wall.

During spill, there are two main water currents, one in the southern portion of the forebay toward the powerhouse and one in the northern portion toward the spillway (Figure 3.12). The higher the proportion of spill, the further south this split occurs. Generally, an eddy forms in the area off the non-overflow portion of the dam between the powerhouse and the spillway. Juvenile fish spill is currently set at $40 \%$ of the total river. This encourages the flow of the river from east to west.

Block loading the west end units (MU 1-5) during the $2002 \mathrm{~J}$-occlusion plate study (see Section 6) was an atypical operation for the purpose of the study. Based on CFD results, there were subtle differences between the block loading operation and the regular alternating sequence for unit priority.

Hydraulic conditions at the east end of the powerhouse are dependent upon turbine unit operations. The flow moving along the Oregon shore, south of Louise Island, has to make an abrupt turn to enter the east end turbine units whereas flow that moves north of Louise Island and over Big Eddy makes a gradual turn into the turbines (Figure 3.12). The higher velocities in the forebay adjacent to the powerhouse are near the east end where flow has to transition more abruptly to enter the turbines.

Forebay hydraulics specific to the sluiceway and turbine studies are contained in Sections 5 and 6 , respectively. Tailrace hydraulic data are presented in Section 4, Spillway Studies. 


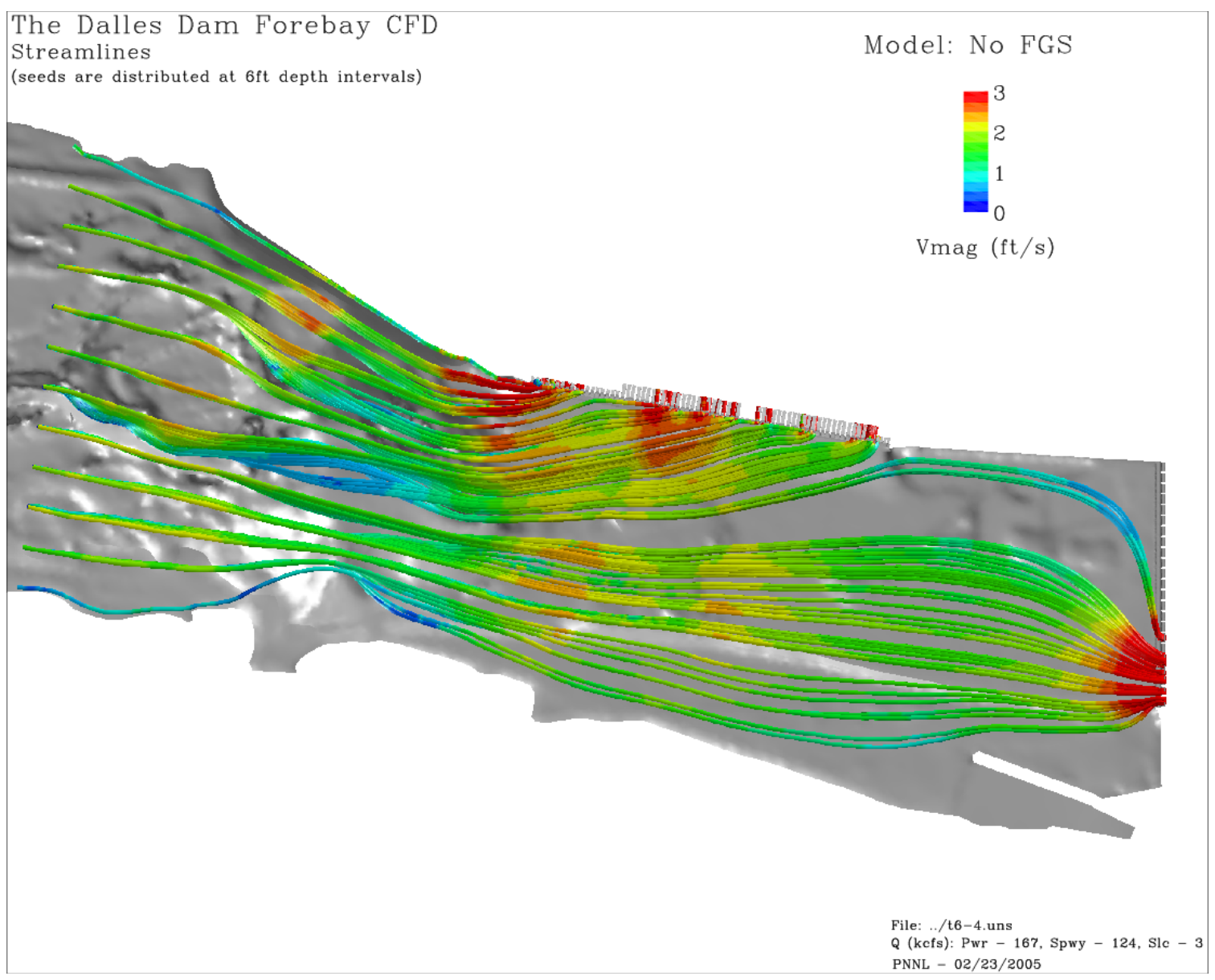

Figure 3.12. Streamlines from a Forebay CFD Model. Conditions are $294 \mathrm{kcfs}$ total river discharge and $42 \%$ spill. The spill pattern calls for bulk spill at Bays 1-6 to correspond with the spillwall in the tailrace. Red and white areas on the powerhouse indicate open and closed portals, respectively. Streamline seeds were distributed uniformly across the forebay about 1,000 ft upstream of the east end of the powerhouse and about $6 \mathrm{ft}$ below the surface. Flow is from left to right. (The figure was provided by L. Ebner, USACE Hydraulics)

\subsection{Summary}

The key findings from the forebay and project passage studies at The Dalles Dam during 20012005 can be summarized as follows:

- Forebay approach and movement data from acoustic- and radio-tagged fish in numerous studies show a consistent pattern. Fish generally migrate downstream with the bulk flow in the thalweg, then take one of two primary pathways once they exit the region of Big Eddy upstream of the dam. One path heads directly to the spillway and one path heads toward the powerhouse. Some of the fish taking the powerhouse pathway move along the powerhouse only to pass it and head to the spillway. These movement patterns are driven by spilling $40 \%$ of total project discharge.

- Residence times in The Dalles Dam forebay, defined as the duration between the time of first detection on dam-mounted, 330-ft-range aerial antennas and the time of last detection on underwater antennas at dam portals, are short, e.g., $0.2 \mathrm{~h}$ for 2002 to $2.9 \mathrm{~h}$ for 2001 (Appendix 
B). Median residence times are about $0.3 \mathrm{~h}$ for yearling and subyearling Chinook salmon and $0.4 \mathrm{~h}$ for steelhead.

- Subtle differences in forebay residence times are present based on passage route and diel period. The differences are consistent with the distances of each route from the upstream end of the forebay -- shortest for turbines, intermediate for sluiceway, and longest for spillway. Diel differences in overall residence time are likely related to project discharge patterns.

- Passage efficiency and effectiveness for 2002-2005 from radio-telemetry data (Appendix C), expressed as means of the yearly values, were as follows (2001 data were not included in these averages because there were substantial periods with no spill):

\begin{tabular}{cccccc}
\hline & \multicolumn{2}{c}{ Efficiency (\%) } & \multicolumn{2}{c}{ Effectiveness } \\
& Sluiceway & Spillway & FPE & Sluiceway & Spillway \\
\hline CH 0 & 7.6 & 72.7 & 80.2 & 3.2 & 1.9 \\
CH 1 & 11.8 & 73.1 & 84.9 & 4.7 & 2.0 \\
STH & 14.0 & 76.0 & 90.0 & 9.3 & 2.0 \\
\hline
\end{tabular}

- The horizontal distribution of fish passage for the run-at-large at the powerhouse is skewed toward the western end of the structure during spring. However, during summer the horizontal distribution is more uniform across the powerhouse with passage rates at eastern units higher during summer than spring. At the spillway, the horizontal distribution during spring is skewed to the southern-most operating bays. During summer at the spillway, passage rates by bay are variable.

- Normalizing the turbine horizontal distribution data by turbine discharge shows that the eastern units have the highest fish densities during summer (fish density = passage per unit flow). Fish densities at the turbines are variable in spring.

- The vertical distribution for the run-at-large from hydroacoustic sampling inside turbine intakes is skewed toward the intake ceiling. Turbine passage is somewhat deeper during night than day. Spillway vertical distribution, which is typically deeper during summer than spring, is variable with peaks toward the surface or the ogee.

- Diel distribution of turbine passage has a crepuscular peak at dusk. Spillway and sluiceway passage tend to be higher during day than night hours, although diel passage patterns are variable among and within study-years.

- Forebay current patterns have two prevalent flow regimes, one toward the powerhouse and one toward the spillway. Forebay current patterns are affected by total river discharge and project operations. 


\subsection{Spillway Studies}

Spillway studies at The Dalles Dam fall into two categories: spillway operations and spillway structures. Spillway operations research concerned spill patterns, spill levels, and the relationship between spill passage efficiency and spill level (proportion or volume). Voluntary spill has been instituted since 1992 to protect juvenile salmonids passing the dam. Voluntary spill is water purposely passed through the spillway in contrast to involuntary spill, which is water that is discharged when river flow exceeds the hydraulic capacity of the powerhouse or the demand for power generation. The prescribed spill operation since 2000 has been $40 \%$ of total project discharge $24 \mathrm{~h} / \mathrm{d}$ from April through August. Spillway structures studies investigate the results of mechanical efforts to improve spill passage conditions, such as the spillwall. Tailrace egress, predation, and mechanisms of fish injury and mortality at the spillway have also been studied extensively. This chapter also contains a detailed section on hydraulics research in the tailrace, especially the spillway stilling basin.

\subsection{Spillway Operations}

The voluntary spill patterns used at The Dalles Dam were modified in 2000 and again in 2004. Prior to 2000, a "juvenile" spill pattern emphasizing more northern (lower numbered) bays was used at night and an "adult" pattern, with spill greatest near the middle of the spillway and limited near the edges to reduce potential impediments to adult ladder use, was used during the day (Figure 2.8). Beginning in 2000 , the juvenile spill pattern was used continuously during the spill season to route spillway-passing fish downstream via the thalweg and avoid passing them near the shallow areas and islands downstream from the spillway. These areas are known to harbor predatory fishes, as described in Section 4.3 .2 and by Martinelli and Shively (1997).

Normandeau et al. (2003) found that direct survival of balloon-tagged juvenile Chinook salmon was lowest for fish released near the powerhouse side of the spill pattern, hypothesized to be due to mortality from lateral flows in the stilling basin. This was also evident in the survival of radio-tagged fish released using the same release methods (Counihan et al. 2006a). In 2004, as a result of fish passage and survival studies through the stilling basin, the juvenile spill pattern was changed to bulk spill in Bays 1-6 after construction of the spillwall in the stilling basin between Bays 6 and 7. The shape of several spill patterns at a spill amount of $40 \%$ of a $200 \mathrm{kcfs}$ total project discharge is shown in Figure 2.8 .

Biological research relative to spill operations includes studies of fish passage and survival through the spillway. Fish passage data in this section include overall spillway efficiency and effectiveness, as well as the distribution of passage through the spillway. The spillway survival work since 2001 has been part of the spillwall evaluations and is included in the Spillway Structures section below. Survival through the spillway relative to powerhouse, sluiceway, and overall dam passage is part of total project and dam survival studies and is presented in Section 7.

The distribution of fish passage across the spillway does not necessarily follow the distribution of spillway discharge (Figure 4.1). Fish passage proportion is greater than discharge proportion near the powerhouse side of the spill pattern, i.e., spill is more effective near that edge of the pattern. This has been evident in several studies based on radio telemetry, acoustic telemetry, and fixed hydroacoustics and it could be seen both before and after the change in juvenile spill pattern after the spillwall construction in 2003-2004 (Beeman et al. 2005, 2006; Cash et al. 2005; Johnson et al. 2003, 2005). An example from radio-tagged Chinook salmon is depicted in Figure 4.1, but a similar pattern was evident in data collected using acoustic-tagged fish and fixed hydroacoustics (Cash et al. 2005; Johnson et al. 2005). The result of 
this relationship is that spill effectiveness (\%fish/\%water) is unequal among spill bays, with those near the powerhouse side of the spill pattern having the highest effectiveness values.
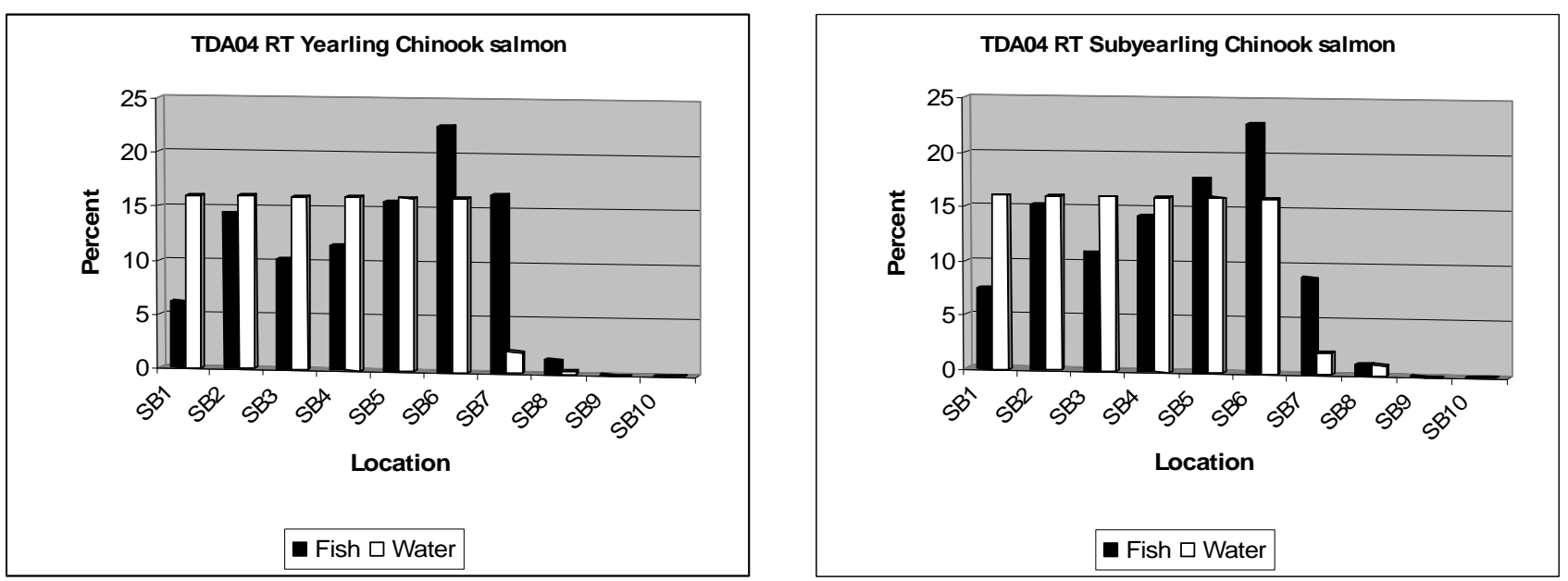

Figure 4.1. Percent of Water Spilled through Spill Bays and the Percent of Volitionally Passing RadioTagged Yearling (left) and Subyearling (right) Chinook Salmon Detected Passing the Bays. Fish were released at or near John Day Dam. (Fish data are from Beeman et al. (2005); discharge data are from USACE.)

A similar pattern in spill effectiveness was evident for radio-tagged yearling and subyearling Chinook salmon in 2004 (Figure 4.2). This relation is likely due to passage of fish approaching the spillway from the powerhouse side of the forebay as they encounter the first one or two open spill bays. This behavior was described by Cash et al. (2005) and Beeman et al. $(2005,2006)$ and was described in Section 3 . The result of this pattern is that even small amounts of spill from bays at the powerhouse side of the spill pattern can pass a relatively high proportion of fish. This is not to say that bays near the southern side of the spillway have inherently higher spill effectiveness; rather, it indicates spill bays near the southern edge of the open spill bays can have high spill effectiveness when open small amounts.

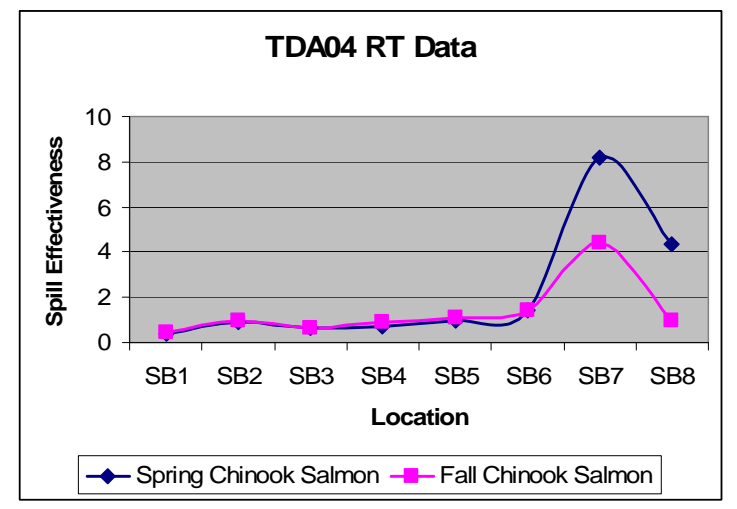

Figure 4.2. Spill Passage Effectiveness by Spill Bay at The Dalles Dam in 2004

The horizontal distribution of fish passage within individual spill bays varies (Figure 4.3). During 2004, Cash et al. (2005) used their array of hydrophones to estimate the horizontal positions of acoustic- 
tagged juvenile salmonids within Spill Bays 1 through 6, the primary spill bays in operation during their study. Passage through Bays 1, 4, and 5 was greatest near the southern edge; passage through Bays 2 and 5 was even across the bays; and passage through bay 3 was greatest near the northern side of the bay (Figure 4.3). The horizontal distributions of passage through bays near the edge of the spill pattern (Bays 1 and 6) were similar (greater to the south).
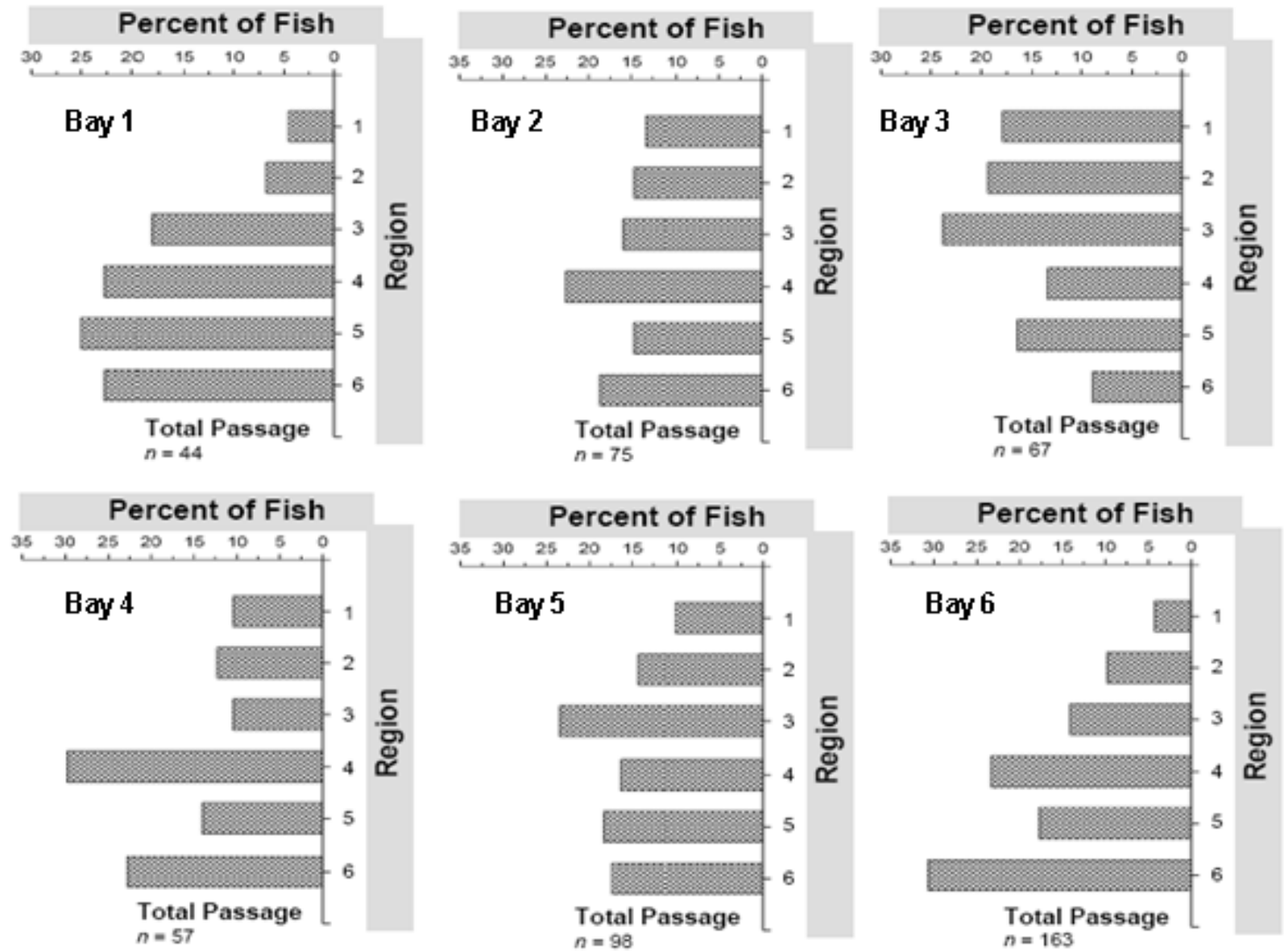

Figure 4.3. Within-Bay Horizontal Distribution of Acoustic-Tagged Juvenile Salmonids at The Dalles Dam, 2004. Steelhead, yearling and subyearling Chinook salmon data were pooled. Each spill bay was divided into six equal regions with region 1 closest to the Washington shore. (From Cash et al. 2005.)

There was little relationship between spill passage efficiency of radio-tagged fish and either spill proportion or spill rate. Plots of daily data from radio-tagged fish in 2005 revealed no trend in spill passage efficiency and spill proportion or spill rate from yearling or subyearling Chinook salmon; however the relation between diel period and spill passage efficiency is apparent (Figure 4.4). The spillway was a more efficient route of passage during day than night. These data for subyearling Chinook salmon indicated a positive relation between spill passage efficiency and spill rate (Figure 4.4). 

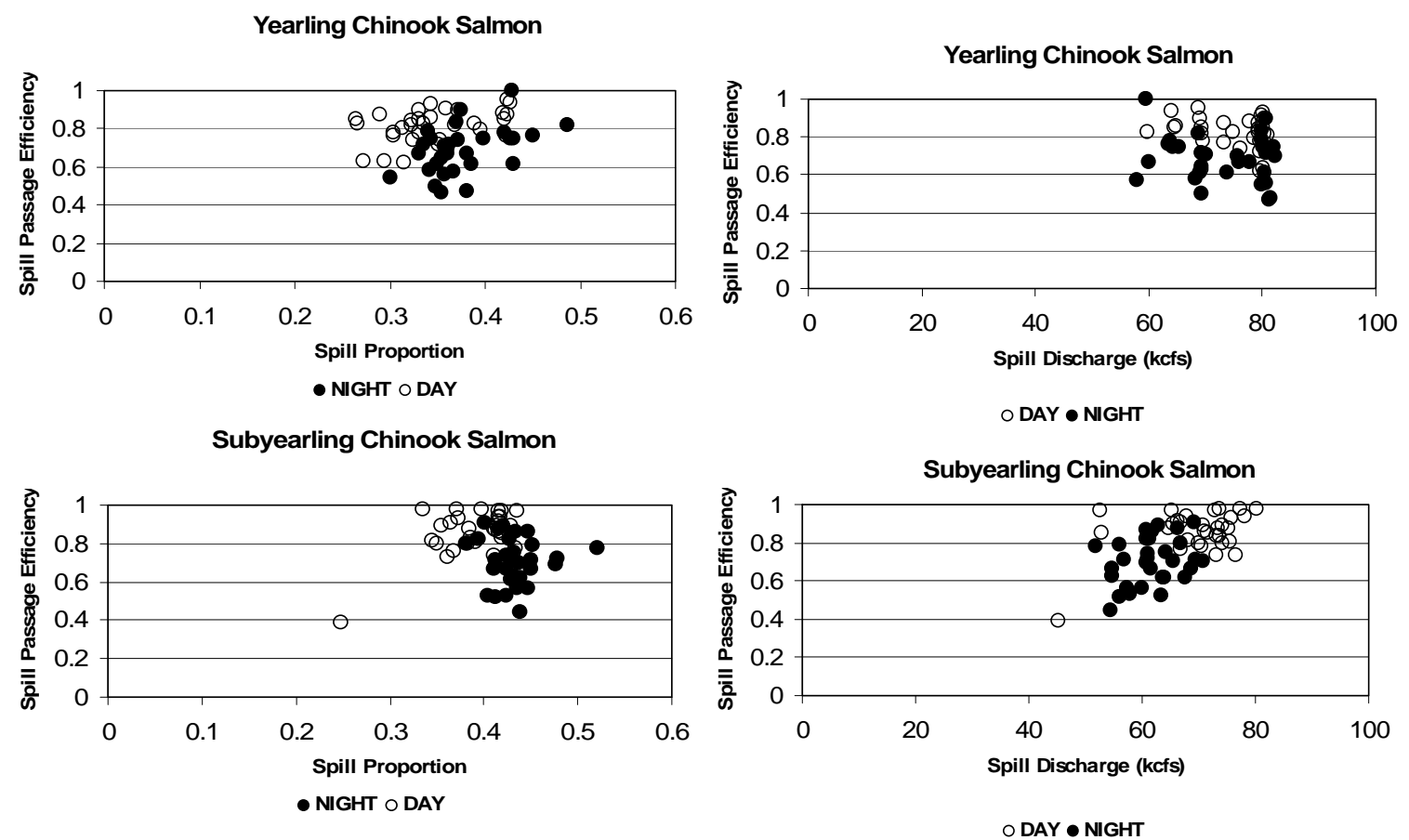

Figure 4.4. Spill Passage Efficiency by Daily Estimates (Day and Night) versus Spill Proportion and Spill Rate (kcfs) for Radio-Tagged Fish in 2005

For hydroacoustic data from 1999-2004 combined, there was no relationship between daily spill passage efficiency and spill proportion or spill discharge for either spring or summer (Figure 4.5). For a given spill operation at The Dalles Dam, e.g., $40 \%$ spill, the daily spill passage efficiency data are variable ranging from 0.3 to nearly 1.0 (Figures $4.5 \mathrm{a}$ and $4.5 \mathrm{c}$ ). The same pattern of variability was true for a given discharge (Figures $4.5 \mathrm{~b}$ and $4.5 \mathrm{~d}$ ). High spill passage efficiency values were observed across a wide range of spill proportions (0.05 to 0.65$)$ and spill discharges (10-230 kcfs; Figure 4.5).

A hierarchical multiple regression analysis of the relationship between spill passage efficiency (daily hydroacoustic data) and independent variables for environmental conditions (water temperature and Julian date) and spill operations (spill proportion and spill discharge) was conducted for hydroacoustic data from studies in 1999, 2000, 2001, 2002, and 2004. In hierarchical regression, non-flow-related parameters were incorporated into the model, followed by relevant flow parameters. The purpose was to see if spill proportion and discharge explained spill passage efficiency after certain ambient factors were considered. Water temperature and Julian date were incorporated into the model, followed by spill proportion and spill discharge. After accounting for water temperature and Julian date, the effect of spill proportion was found to be significant $(P \approx 0)$, while spill discharge was not $(P=0.82$; Table 4.1$)$. Water temperature and Julian date alone explained $56 \%$ of the variance in daily spill passage efficiency. Adding spill proportion to the model increased the $\mathrm{R}^{2}$ to $61 \%$. Further hierarchical and stepwise multiple regressions with spill passage abundance and spill effectiveness as response variables are presented in Appendix D. 

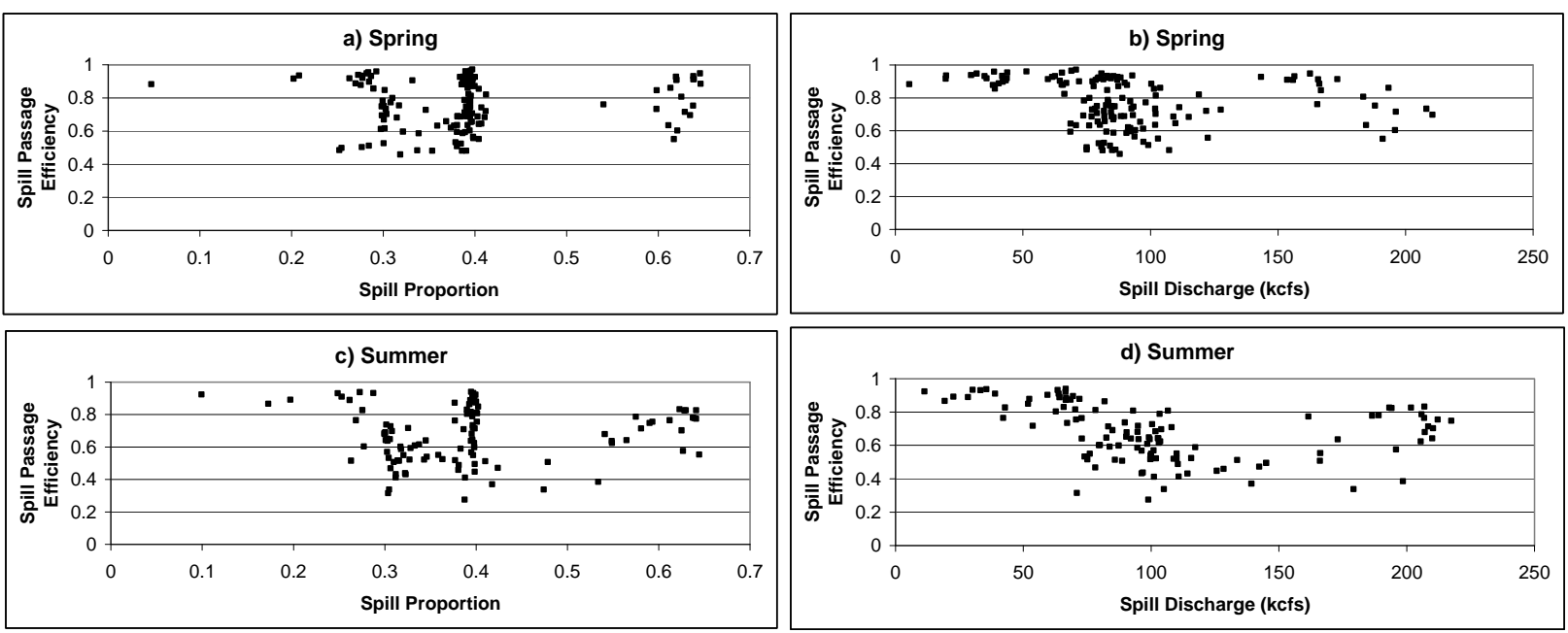

Figure 4.5. Spill Passage Efficiency by Season versus Spill Proportion and Spill Discharge. The data are daily hydroacoustic estimates from 1999, 2000, 2001, 2002, and 2004. Spill passage efficiency was computed as follows: spill passage divided by spill plus powerhouse passage.

Table 4.1. Hierarchical Regression for Spill Passage Efficiency Testing the Significance of Spill Proportion and Spill Discharge after Accounting for Significant Environmental Covariates (Water Temperature and Julian Date). (This analysis was performed by J. Skalski and J. Griswold, UW.)

\begin{tabular}{|c|c|c|c|c|c|c|}
\hline Source & $\mathrm{DF}$ & SS & MS & $F$ & $P$ & $R^{2}$ \\
\hline Total $_{\mathrm{COR}}$ & 258 & 80588.50 & & & & \\
\hline Env. covariates* & 2 & 44772.33 & 5 & $F_{2,256}=160.01$ & $\approx 0$ & 0.556 \\
\hline Error & 256 & 35816.17 & $14^{139.9069}$ & & & \\
\hline $\begin{array}{l}\text { Spill Discharge } \\
\text { Error }\end{array}$ & $\begin{array}{r}1 \\
255\end{array}$ & $\begin{array}{r}7.60 \\
35808.57\end{array}$ & $\begin{array}{c}7.6 \\
6^{140.4257}\end{array}$ & $\mathrm{~F}_{1,255}=0.05$ & 0.82 & 0.556 \\
\hline $\begin{array}{l}\text { Spill Proportion } \\
\text { Error }\end{array}$ & $\begin{array}{r}1 \\
255\end{array}$ & $\begin{array}{r}4052.72 \\
31763.45\end{array}$ & $\begin{array}{l}4052.72 \\
124.56\end{array}$ & $\mathrm{~F}_{1,255}=32.54$ & $\approx 0$ & 0.606 \\
\hline
\end{tabular}

* Environmental covariates entered into model: water temperature and Julian date.

\subsection{Spillway Structures}

Historically, structures used to improve spillway passage or survival have included devices in the forebay and stilling basin. Most research, however, has been devoted to study of the stilling basin and tailrace environment, although there was one study of surface spill in 1995. The 1995 study evaluated use of bulkheads modified to allow a comparison of fish passed through an unmodified bay (Bay 3) and those with shallow passage routes at Bays 4 (I-slot) and 6 (overflow weir; Normandeau et al. 1996). These devices were evaluated in terms of their effects on the condition and injury of balloon-tagged juvenile Chinook salmon released into the spill bays via pipes during the fall of the year. The results indicated 
little difference between unmodified and modified spill bays, although the results were confounded with discharge through the bays. The remainder of this section will be devoted to development of the spillwall in the stilling basin.

A concrete wall (10 ft wide, $43 \mathrm{ft}$ high, $193 \mathrm{ft}$ long) was constructed in the stilling basin between spill Bays 6 and 7 during winter 2003/2004 as a result of studies to determine why survival of fish passing the spillway at The Dalles Dam was lower than at other lower Columbia River dams. These studies included those of direct fish injury and survival, direct plus indirect survival, sensor packages, radio-tagged fish, and movements of GPS-equipped drogues (Figure 4.6) (Normandeau et al. 2003, 2004; Counihan et al. 2006a; Beeman et al. 2003, 2006).

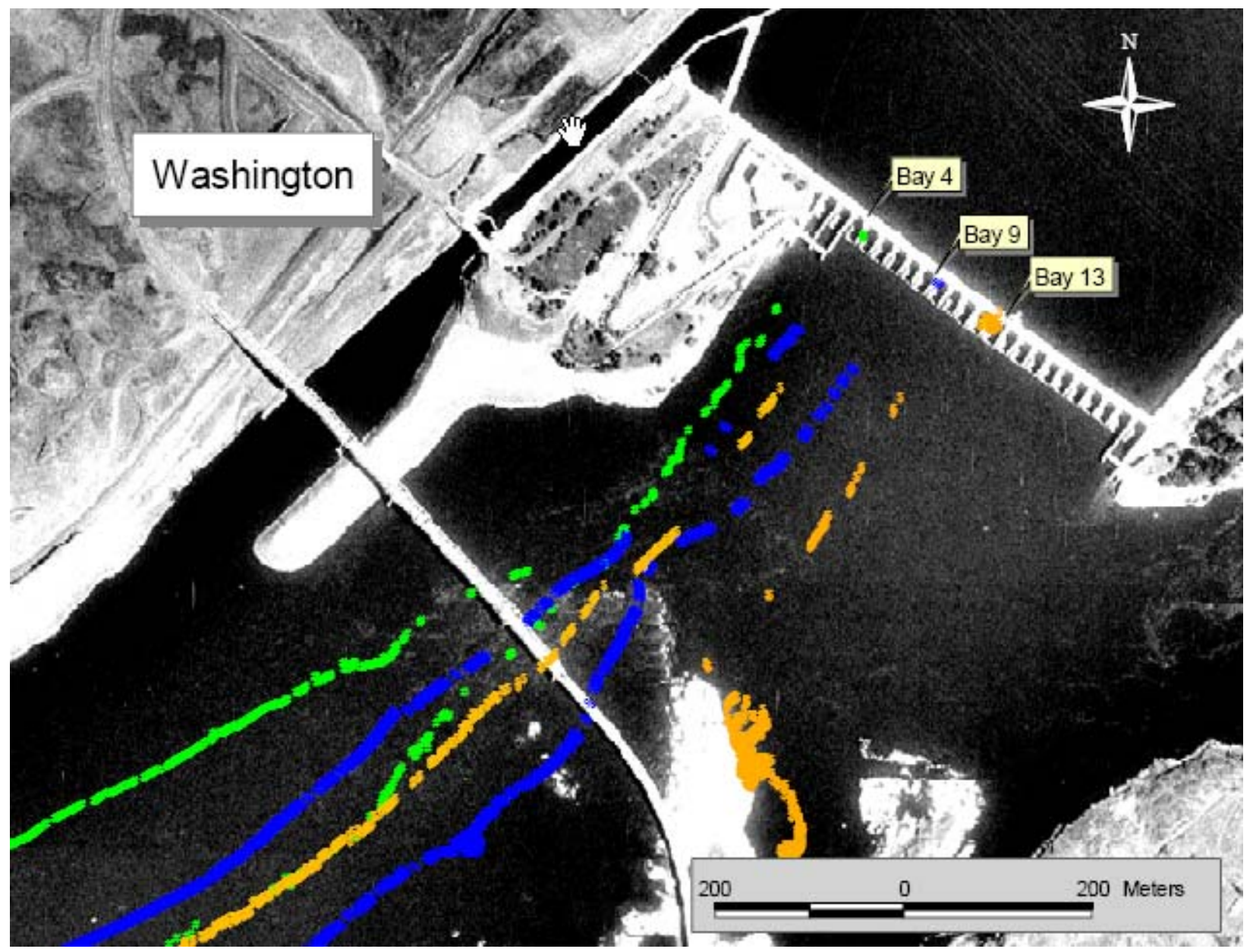

Figure 4.6. Representative Drogue Movement Paths following Releases at The Dalles Dam Spillway from May 5 to August 7, 2002. Drogues were released through Bays 4, 9, and 13. Two representative drogue paths were chosen for each of the three release locations. The background photo does not represent study conditions. (Figure is from Beeman et al. 2006.)

Results of survival estimates of balloon-tagged (direct mortality) and radio-tagged (direct plus indirect mortality) fish released into spill bays through hoses in 2002 were similar (Table 4.2). Each method indicated lower survival of fish released through a spill bay near the edge of the spill pattern on the southern spillway than for fish released through the northern spillway (Counihan et al. 2006a, 
Normandeau et al. 2003). Results of the various studies together indicated fish passing through southern bays were entrained in the lateral movement of water toward northern bays within the stilling basin, resulting in an increased residence time in this environment. This increase in residence time was believed to increase the potential for strike and shear injuries, causing lower survival. Paths of drogues equipped with a global positioning system (GPS) clearly show the lateral movement within the stilling basin prior to wall construction. Thus, the spillwall was installed and a new spill pattern was developed to reduce the number of fish passed in bays south of Bay 6 and to stop the lateral movement of water and fish through the stilling basin (Figure 4.7). A 47-ft extension of the wall between the north adult ladder entrance and spill bay one was also added during the winter of 2003/2004, but no studies of potential effects on juvenile salmonids specific to this wall were conducted.

Table 4.2. Estimates of Survival of Fish Released through Hoses into Spill Bays at The Dalles Dam in 2002. Data are from balloon-tagged fish (Normandeau et al. 2003) and radio-tagged fish (Counihan et al. 2006a). Balloon-tagged fish were Chinook salmon from a hatchery; radiotagged fish were collected from the run-at-large at John Day Dam. Bay 13 was used in spring and Bay 11 was used in summer. Point estimates are followed by $95 \%$ (radio) or $90 \%$ (balloon) confidence intervals.

\begin{tabular}{|c|c|c|c|c|c|}
\hline \multirow[b]{2}{*}{ Season } & \multirow[b]{2}{*}{ Method } & \multirow[b]{2}{*}{ Note } & \multicolumn{3}{|c|}{ Spill Bay } \\
\hline & & & Bay 4 & Bay 9 & Bay 11 or 13 \\
\hline \multirow[t]{4}{*}{ Spring } & Balloon & May test & 0.974 & 0.974 & 0.938 \\
\hline & & & $0.957-0.990$ & $0.957-0.991$ & $0.916-0.961$ \\
\hline & Radio & Yearling Chinook & 0.980 & 0.950 & 0.920 \\
\hline & & Salmon & $0.951-1.009$ & $0.917-0.983$ & $0.869-0.971$ \\
\hline \multirow[t]{4}{*}{ Summer } & Balloon & August test & 0.936 & 0.933 & 0.926 \\
\hline & & & $0.888-0.980$ & $0.881-0.980$ & $0.876-0.972$ \\
\hline & Radio & Subyearling & 1.000 & ------ & 0.970 \\
\hline & & Chinook Salmon & $0.974-1.026$ & & $0.922-1.018$ \\
\hline
\end{tabular}




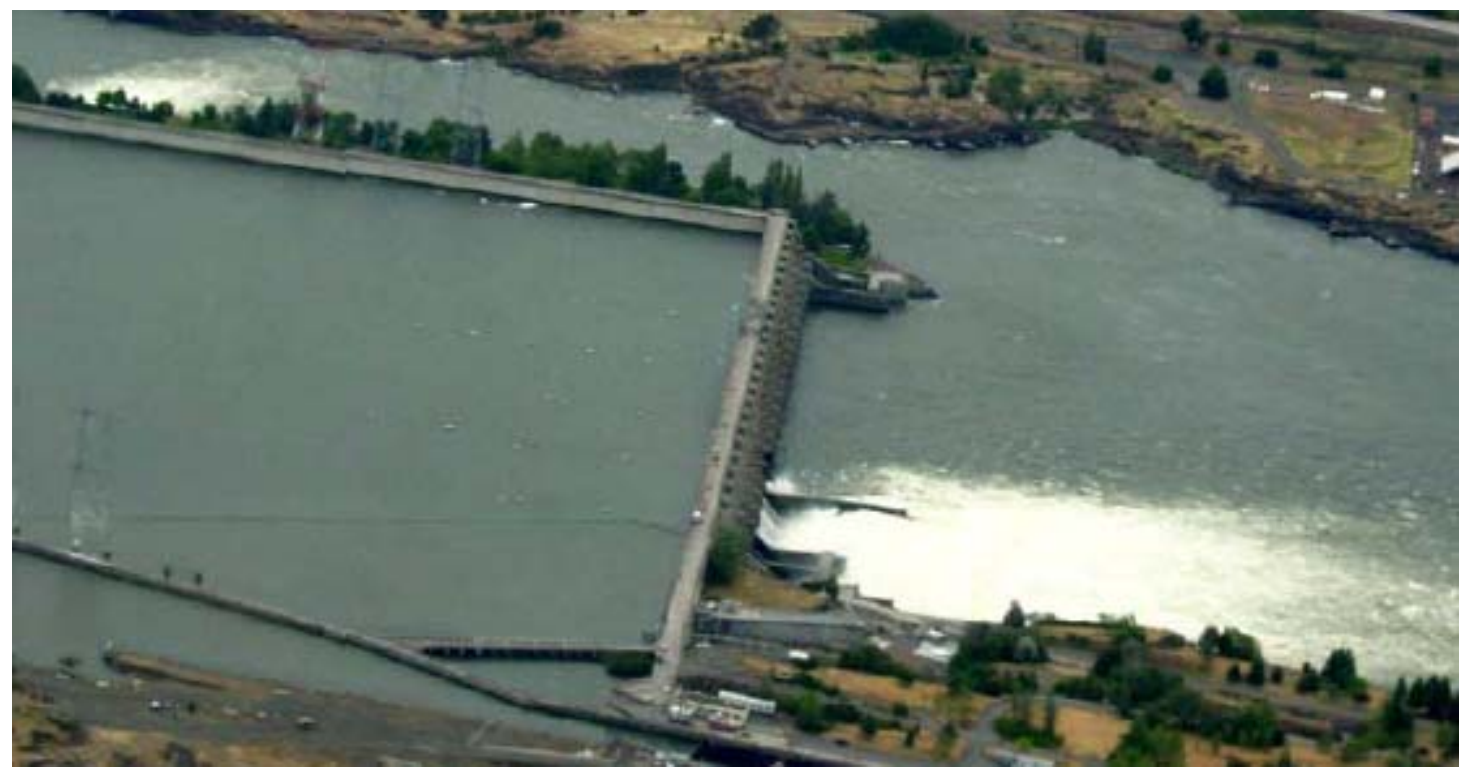

Figure 4.7. The Dalles Dam on June 12, 2004, Illustrating the Wall between Spill Bays 6 and 7. Spill was occurring through Bays 1 to 7 during the photo. Note the increasing spreading of airentrained water to the top (south) of the photo with distance from the dam.

The overall survival of fish passing via the spillway after construction of the spillwall was similar to pre-wall conditions (Tables 4.2 and 4.3). The survival of radio-tagged fish passing through Bays 1-4 and of fish passing through Bays 5-6 was estimated in 2004, 2005, and 2006 (Counihan et al. 2006b, 2006c). During each study-year, the survival of fish passing Bays 1-4 was greater than that of fish passing Bays 5 and 6. The point estimates of survival through these two groupings were generally greater during the spring than the summer, but the difference between bays was larger during the summer than the spring (Table 4.3).

Survival and injury of balloon-tagged fish was estimated in 2004, including fish hand-tossed into the vortex at Bay 6 (described in next section; Normandeau and Skalski 2005). The estimated survival of the Bay 6 fish (0.851) was lower than that of fish released into Bays 2 or 4 (0.977 to 0.990, depending on bay and treatment). The prevalence of injuries was similar among bays (0.3-5.6\% of treatment fish), with the most common injuries being of the eyes, opercula, and gills; these are described further in Section 4.4.

The cause of the lower survival in Bays 5 and 6 has not been definitively identified, but it was speculated that it may have been caused by fish contacting baffle blocks or the end sill during passage or by conditions downstream from the stilling basin. (A gap between a baffle block and the wall was filled in winter 2006/2007.) Metal protrusions along the wall were removed prior to the 2005 fish migration season, but estimates of injury and survival remained similar to previous years (Table 4.3). One other potential cause is a change in predator distribution after wall construction resulting in greater predation of fish passing Bays 5 and 6, as this is generally the southern edge of the spill pattern. Preliminary plans to extend the spillwall to reduce this potential were being developed at the time of this report.

Table 4.3. Estimated Survivals and 95\% Confidence Limits of Radio-Tagged Fish Volitionally Passing the Spillway at The Dalles Dam. Fish were released near John Day Dam in 2004 and 2005 and in the forebay of The Dalles Dam in 2006. Single release estimates for 2005 were calculated for comparison with 2006 data. (Data are from Counihan et al. 2006b, 2006c; Puls et al. in preparation) 


\begin{tabular}{ccccc}
\hline & \multicolumn{2}{c}{ Yearling Chinook Salmon } & \multicolumn{2}{c}{ Subyearling Chinook Salmon } \\
\cline { 2 - 5 } Study & Spill Bays 1-4 & Spill Bays 5-6 & Spill Bays 1-4 & Spill Bays 5-6 \\
\hline $\begin{array}{c}2004 \text { Paired } \\
\text { release }\end{array}$ & 0.933 & 0.894 & 0.907 & 0.800 \\
$\begin{array}{c}2005 \text { Paired } \\
\text { release }\end{array}$ & $0.906,0.960$ & $0.866,0.922$ & $0.869,0.945$ & $0.730,0.870$ \\
$\begin{array}{c}\text { 2005 Single } \\
\text { release }\end{array}$ & $0.931,1.003$ & $0.899,0.966$ & $0.950,0.995$ & $0.843,0.930$ \\
$\begin{array}{c}\text { 2006 Single } \\
\text { release }\end{array}$ & $0.846,1.066$ & $0.815,0.993$ & $0.901,1.065$ & $0.724,1.014$ \\
\hline
\end{tabular}

\subsection{Tailrace Egress and Predation}

Many of the changes in operations to improve downstream passage of juvenile salmonids at The Dalles Dam are driven by egress and predation issues in the tailrace. As described earlier, the tailrace of The Dalles Dam is a complex mix of deep canyons, shallow sills, and islands. These attributes result in conditions suitable for pisciverous fish and birds to prey on juvenile salmonids after they pass the dam. The goal of the most recent spill patterns is to pass fish from the spillway to the thalweg instead of the islands downstream of the dam. This is driven by knowledge of the habitat and locations of pisciverous fish in the many shallow areas and islands downstream. This section describes tailrace egress rates, predation in the tailrace, and mechanisms of mortality during spillway passage.

\subsubsection{Tailrace Egress}

Studies of tailrace egress have been conducted primarily using radio-tagged fish and GPS-equipped drogues, although some egress data are available from balloon-tag studies. The goals of the studies have been to determine the egress rates and routes of juvenile salmonids as they pass through the tailrace of the dam under various conditions. Studies have measured the egress of yearling and subyearling Chinook salmon from the area of passage to an area $1.7 \mathrm{~km}$ or $4.7 \mathrm{~km}$ downstream from the spillway.

Despite differences in study objectives among years, general conclusions can be drawn about egress rates of yearling and subyearling Chinook salmon passing the spillway, sluiceway, and powerhouse. The tailrace egress of juvenile Chinook salmon through The Dalles Dam tailrace is faster when fish pass through the spillway than through the sluiceway or powerhouse (Table 4.4). This is likely the result of differences in the distance from passage to the measurement point below the dam, and the presence or absence of islands, rock outcroppings, or eddies among the routes (Allen et al. in preparation; Duran et al. 2006; Daniel et al. in review.). Tailrace egress from the spillway is also shorter in length than other routes of egress. Furthermore, passage through the north side of the spillway results in shorter median tailrace egress rates than passage through the south side of the spillway. Diel differences also exist, with shorter median tailrace migration times generally occurring during the day, though this may be a result of diel differences in discharge rather than fish behavior. Yearling Chinook salmon also tend to have shorter median tailrace migration times than subyearling Chinook salmon. 
Direct year-to-year comparisons of egress studies conducted from 2001 to 2005 are difficult due to differing objectives among the studies. Perhaps the most important of these was a change in the point to which egress was measured. Prior to 2004, egress was measured to an area $1.7 \mathrm{~km}$ downstream from the dam, but beginning in 2004 it was measured to an area $4.7 \mathrm{~km}$ downstream. In addition, discharge in 2001 was much lower than in other years, resulting in longer egress times. Total discharge and spill volume was relatively similar among other years $(2002,2004-2005)$. 
Table 4.4. Median Tailrace Migration Times (minutes) of Radio-tagged Juvenile Chinook Salmon Passing The Dalles Dam to the Exit Point Transect, $1.7 \mathrm{~km}$ (2001 and 2002) and $4.7 \mathrm{~km}$ (2004 and 2005) Downriver from the Dam. Day and night were defined using sunrise and sunset times. Ranges are in parentheses.

\begin{tabular}{|c|c|c|c|c|c|c|c|}
\hline & N. Spill & M. Spill & S. Spill & Bridge Control & Spill Control & Sluiceway & Powerhouse \\
\hline \multicolumn{8}{|l|}{2001} \\
\hline CHIN 1 & & & & & & 135.9 & \\
\hline Day & & & & & & $151.1(30.9-1054.8)$ & \\
\hline Night & & & & & & $124.1(55.3-834.3)$ & \\
\hline CHIN 0 & & & & & & 120.7 & \\
\hline Day & & & & & & $106.9(41.4-1146.7)$ & \\
\hline Night & & & & & & $131.3(43.2-760.8)$ & \\
\hline \multicolumn{8}{|l|}{$2002^{1}$} \\
\hline CHIN 1 & 16.2 & 19.7 & 22.7 & 12.0 & 15.8 & & \\
\hline Day & $15.4(9.5-32.8)$ & $19.6(10.7-51.7)$ & $19.8(5.4-1492.1)$ & $11.0(6.7-25.9)$ & $15.4(10.1-26.4)$ & & \\
\hline Night & $16.5(11.1-37.0)$ & $19.8(11.1-394.8)$ & $25.8(12.4-98.5)$ & $12.9(5.8-25.5)$ & $16.5(10.6-36.1)$ & & \\
\hline CHIN 0 & 17.7 & & 26.8 & & 19.1 & & \\
\hline Day & $19.2(7.6-80.4)$ & & $37.4(15.7-620.1)$ & & $20.0(11.1-93.6)$ & & \\
\hline Night & $16.3(10.6-31.4)$ & & $21.8(10.1-319.1)$ & & $17.7(8.5-45.2)$ & & \\
\hline \multicolumn{8}{|l|}{$2003^{2}$} \\
\hline \multicolumn{8}{|l|}{$2004^{3}$} \\
\hline CHIN 1 & & 103.2 & & & & 152.4 & 155.4 \\
\hline Day & & $100.8(13.2-2016.0)$ & & & & $141.0(88.8-695.4)$ & $144.0(75.0-222.0)$ \\
\hline Night & & $106.8(60.6-995.4)$ & & & & $148.2(90.0-910.2)$ & $159.0(100.8-3558.0)$ \\
\hline CHIN 0 & & 120.0 & & & & 216.0 & 223.2 \\
\hline Day & & $110.4(12.0-931.2)$ & & & & $186.6(103.8-982.8)$ & $165.0(97.8-598.8)$ \\
\hline Night & & $163.2(72.0-1348.2)$ & & & & $225.6(142.8-514.2)$ & $239.4(117.0-7021.8)$ \\
\hline \multicolumn{8}{|l|}{$2005^{4}$} \\
\hline CHIN 1 & $29.1(10.1-2758.5)$ & & $36.8(12.4-1062.2)$ & & & 71.8 & \\
\hline Day $^{5}$ & & $31.4(12.7-9487.4)$ & & & & $91.6(27.9-10398.7)$ & \\
\hline Night $^{5}$ & & $35.4(10.1-1450.6)$ & & & & $64.0(29.2-3556.0)$ & \\
\hline CHIN 0 & $31.8(15.8-10204.8)$ & & $39.9(16.7-1331.6)$ & & & 103.5 & \\
\hline Day $^{5}$ & & $33.8(15.8-10204.8)$ & & & & $129.6(43.0-18503.9)$ & \\
\hline Night $^{5}$ & & $41.5(14.2-1187.1)$ & & & & $100.4(44.2-1741.8)$ & \\
\hline
\end{tabular}

Notes 1. N. spill=bay 4, M. spill = bay 9 S. spill = bay 13. 2. No egress studies conducted at The Dalles Dam. 3. Exit point transect located $4.7 \mathrm{~km}$ downstream, spillway routes not differentiated. 4 . N. spill=bays $1-4$, S. spill = bays $5 \& 6$. 5. Spillway passage routes not differentiated. 


\subsubsection{Predation Studies}

In 2002, Duran et al. (2003) studied the behavior and distribution of radio-tagged northern pikeminnow (Ptychocheilus oregonensis; NPM), smallmouth bass (Micropterus dolomieu; SMB), and juvenile Chinook salmon to describe the risk of predation in The Dalles Dam tailrace during outmigration periods. These data were used to identify specific areas where predation risk was greatest. This study used radio-tagged yearling and subyearling Chinook salmon released into the sluiceway of TDA as potential prey for the radio-tagged predators.

Detections of northern pikeminnow and smallmouth bass within the study area suggested that their spatial distribution was not random, and certain conditions were preferred. The distributions of northern pikeminnow were similar to a 1993-1994 evaluation in The Dalles Dam tailrace (Martinelli and Shively 1997). The greatest proportion of detections of northern pikeminnow occurred within the basin islands while the smallest proportion of detections was observed near the powerhouse and sluiceway. The areas of greatest juvenile salmonid risk of predation by SMB include the basin islands and areas within the boat-restricted zone (BRZ), the navigation lock, the Washington shore downstream from the navigation lock, and the Oregon shore across from the powerhouse. Some seasonal differences were also noted, with the highest residency being during the spring period. The chief areas of predation risk due to NPM and $\mathrm{SMB}$ were the basin islands and BRZ islands areas. However, it was not possible to determine exactly where prey were consumed.

The distributions of NPM and SMB within The Dalles Dam tailrace were not identical, suggesting these species may have different habitat preferences or responses to juvenile salmonid migration patterns (Figure 4.8). The SMB were found more often near the Washington shore than the NPM. Higher use of the Washington shore by SMB could expose salmonids that pass through the north spill gates to higher predation risk from this species. There also appeared to be some separation of the predator species east of the sluiceway, with SMB more commonly detected there than NPM. Both species were often found in the basin and BRZ island areas.

Predation of radio-tagged juvenile salmonids increased between out-migration periods, supporting other evidence that consumption rates of northern pikeminnow and smallmouth bass increase between spring and summer (Vigg et al. 1991). Temperature generally increases steadily during spring and summer, and the energetic demands of higher temperature could cause increased consumption rates by both predator species (Petersen and Ward 1999). Size-related vulnerability may partially explain this trend (Poe et al. 1991), with the smaller subyearling Chinook salmon being more susceptible to predators than larger yearling Chinook salmon. Yearling Chinook salmon also spent less time within the BRZ (0.7 $\mathrm{h})$ and the tailrace $(1.1 \mathrm{~h})$ than subyearling Chinook salmon $(0.9 \mathrm{~h}$ and $1.2 \mathrm{~h}$, respectively). 


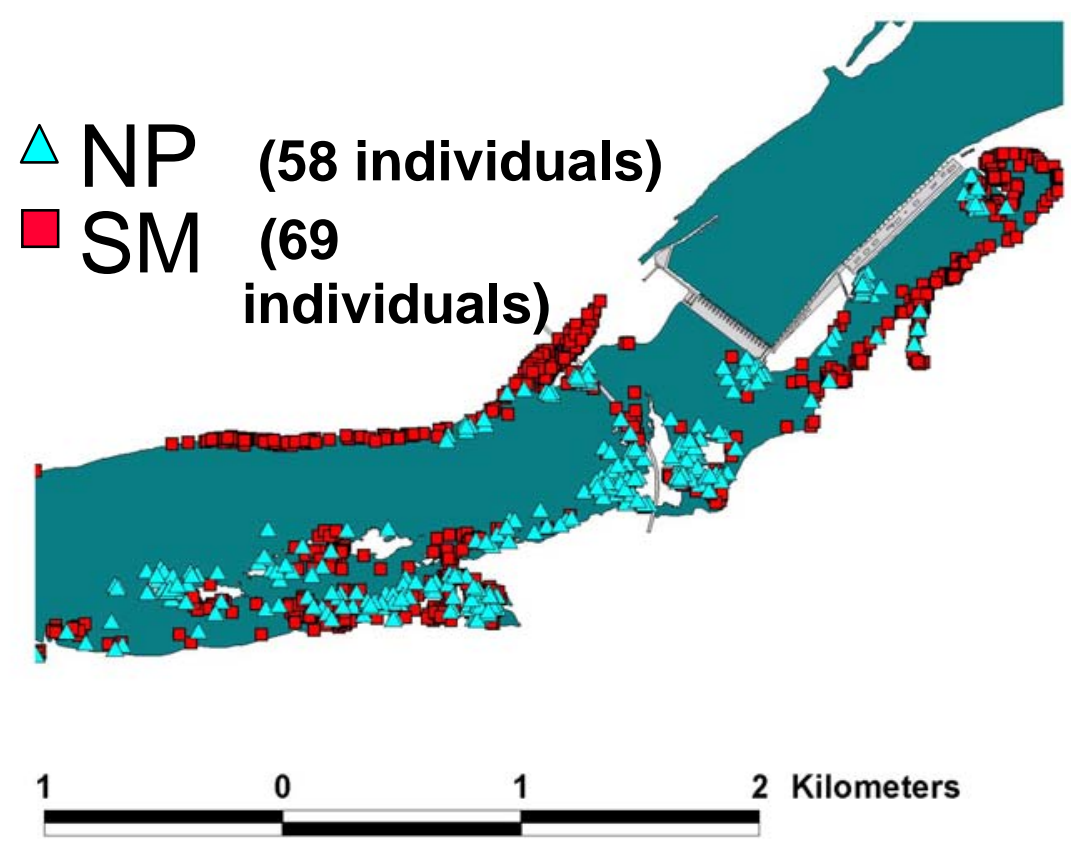

Figure 4.8. Locations of Radio-Tagged Predators in The Dalles Dam Tailrace, 2002. Each point represents a fish location collected via boat tracking.

Data describing predator and prey locations in the tailrace could be used to choose an alternative outfall site for the sluiceway or for another type of juvenile bypass system (JBS). Several researchers have advised that if a JBS were constructed at The Dalles Dam that it should be located in water flow $\geq$ $100 \mathrm{~cm} / \mathrm{s}, \geq 75 \mathrm{~m}$ from structures, in water $\geq 10 \mathrm{~m}$ deep, and far from eddies, submerged cover, and littoral areas (Mesa and Olson 1993; Shively et al. 1996). Few detections of NPM and SMB occurred outside these criteria (Duran et al. 2003; Figure 4.9). Similarly, Faler et al. (1988) found northern pikeminnow avoided high flow associated with spill gate operation in the tailrace of McNary Dam. Helfman (1986) and Hoff (1991) established that predator association with cover is potentially important for several reasons, including protection from predators, attraction of forage fish, and predation advantage. In addition, physical cover has been found to be an important factor in habitat selection by SMB in free-flowing systems (Probst et al. 1984; Sechnick et al. 1986; Todd and Rabeni 1989; Bevelhimer 1996). 

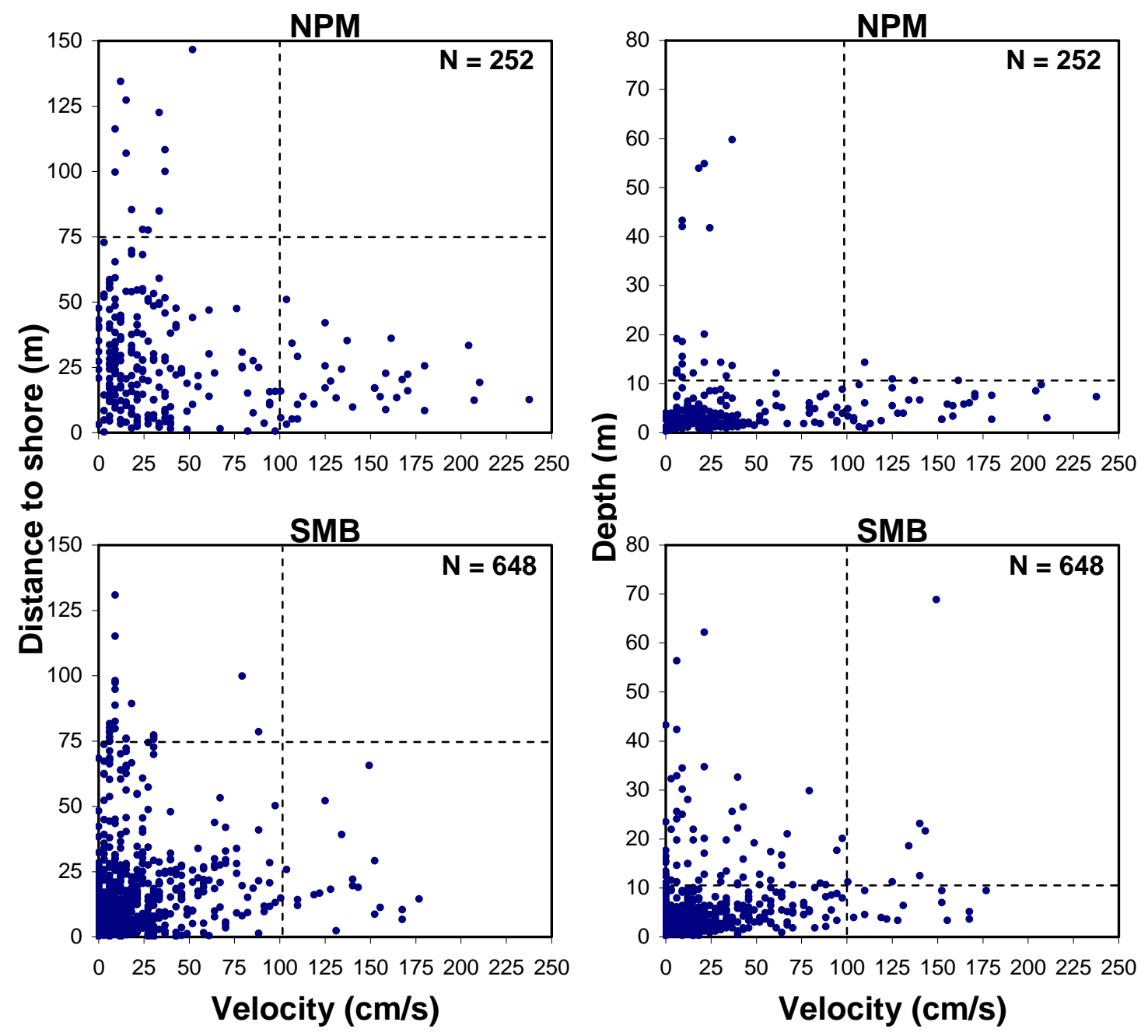

Figure 4.9. Scatter Plots of Distance from Shore and River Depth versus Water Velocity Associated with Locations of Radio-Tagged Northern Pikeminnow (NPM) and Smallmouth Bass (SMB) in The Dalles Dam Tailrace, 2002. Dotted lines represent recommendations of juvenile bypass outfall locations.

\subsection{Mechanisms of Fish Injury and Mortality at the Spillway}

Several studies of fish injury and survival have been conducted using balloon tags since 2001 (Normandeau et al. 2001, 2004; Normandeau and Skalski 2005). Studies were conducted before and after construction of the spillwall. The specific goals of each study were different, but together they describe fish injury and survival relative to the effects of vertical and horizontal passage location within a spill bay, passage among spill bays, tailwater elevations, and discharge per spill bay.

The primary fish injuries were on the head in each study. The most prevalent types were hemorrhages or ruptures of the eye, torn operculum, and scrapes and bruises. Overall rates of injury related to passage ranged from $0 \%$ to $11 \%$. Most injuries were generally found when releases were made off-center in a spill bay; this was believed to result in a higher chance of fish striking baffle blocks (see Figure 4.10). The fewest injuries generally occurred after mid-bay releases during moderate-to-high spill bay discharge (10-20 kcfs with training spill). No consistent relation was found between release depth and injuries (Normandeau et al. 2004). The injuries to the eye and operculum were attributed to damage 
from shear forces. Scrapes and bruises to the head were attributed to mechanical contact with solid objects, such as the baffle blocks, the end sill, or rocks.
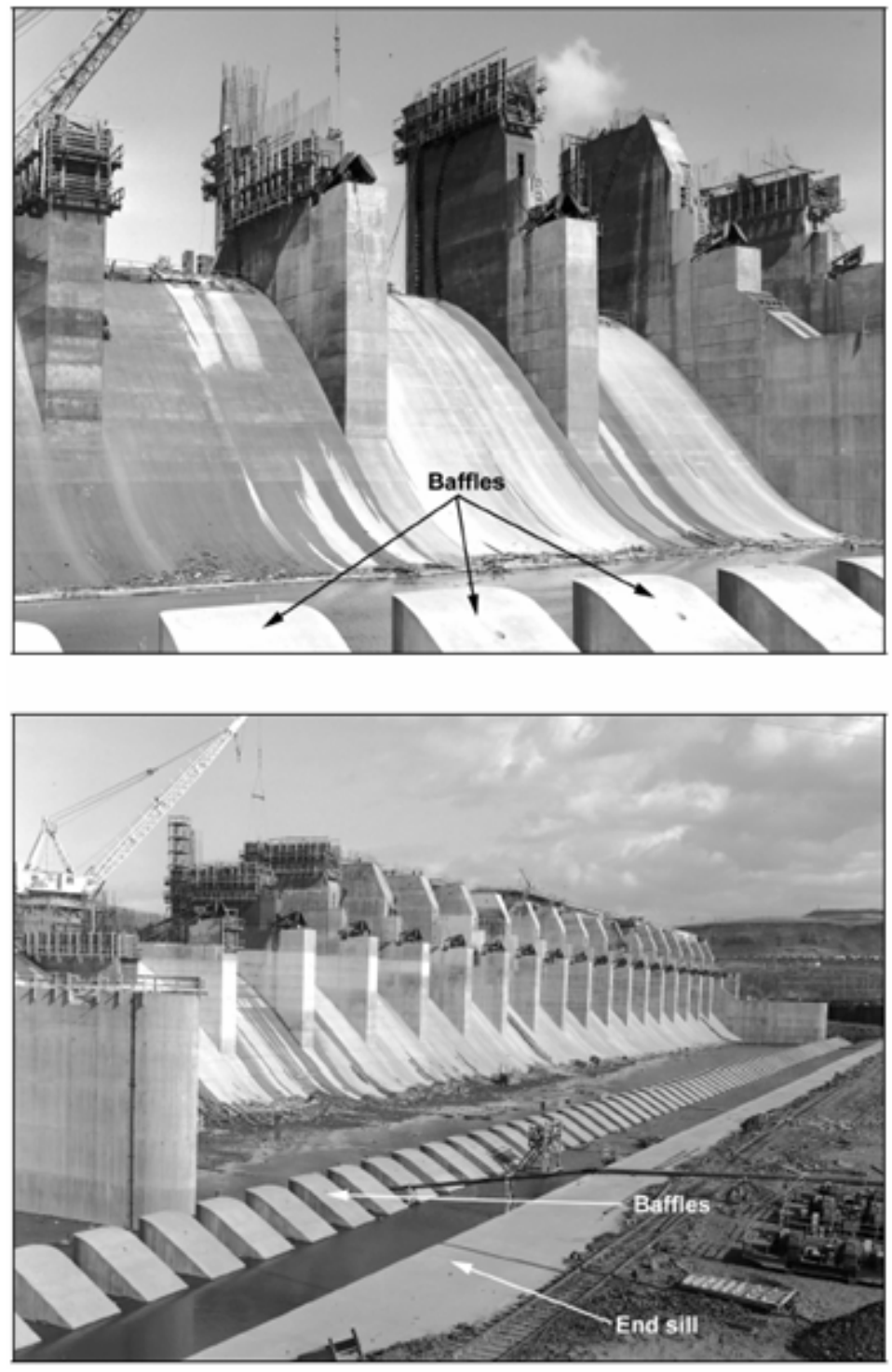

Figure 4.10. The Dalles Dam Spillway with Energy Dissipation Structures $(9 \mathrm{ft}$ high baffles and $13 \mathrm{ft}$ high end sill). (Photos by U.S. Army Corps of Engineers; from Normandeau et al. 2004.)

Greater-than-expected mortality due to predation after tests in August 2002 was observed. Normandeau et al. (2003) noted higher than normal predation of tagged fish during trials in August than in May, citing water temperature (range $19.5^{\circ}$ to $21.6^{\circ} \mathrm{C}$ August vs. $10.0^{\circ}$ to $12.3^{\circ} \mathrm{C}$ May) as a contributing factor. The losses of experimental fish due to predation $(7 \%$ to $16 \%)$ resulted in premature cancellation of the experiment.

For balloon-tagged fish passing the spillway, injury type and frequency was generally similar before and after construction of the spillwall. A trend of higher injury rates for fish released through highernumbered bays was present in pre-wall conditions and persisted at the time of this report. Normandeau et al. (2004) reported lower survival and higher injury rates for fish passing via Bay 6 than Bays 2 or 4 . Injury rates of fish from Spill Bay 6 ranged from 5.3\% to 8.3\% and those from Bays 2 and 4 ranged from 
$0.6 \%$ to $6.3 \%$. Survival probabilities of Bay 6 fish were 0.959 (SE 0.038 ) at high tailwater elevation (80 to $83 \mathrm{ft}$ ) and 0.851 (SE 0.030) at low tailwater elevation (76 to $80 \mathrm{ft}$ ). Survival probabilities of fish from Bays 2 and 4 were greater than 0.96 (SE 0.007 to 0.018) in all trials.

The 2004 study incorporated the spatial location of fish recovery sites, which aided in the interpretation of the survival and injury results. Most Bay 2 and 4 fish were recovered in or near the main river channel in water over $50 \mathrm{ft}$ deep. Most fish from Spill Bay 6 were swept near the rock shelf to the south of the main river channel. Inasmuch as the rock shelf is known to harbor predatory fishes, predation was chosen as the most probable cause of mortality of the Bay 6 fish, though fish from Bay 6 also had a higher incidence of injuries than those from the other bays. Normandeau et al. (2004) concluded that fish from Spill Bays 2 and 4 were favorably affected by the presence of the spillwall. This was supported by egress consistent with little evidence of lateral movement in the stilling basin and few potential collisions with baffle blocks. However, they suggested that passing fish via the southern side of Spill Bay 6 could reduce overall spillway survival and should be avoided. The horizontal distribution of fish passing the spillway was described in Section 4.1.

\subsection{Tailrace Hydraulics Research}

A 1:80 general physical model of The Dalles Dam has been the primary tool to evaluate the hydraulic conditions in the tailrace of the project. The physical model, located at ERDC, was built in 1991. The model covers a 2.4-mile stretch of the river, approximately 1.4 miles upstream and 1 mile downstream of the spillway. Limited prototype data exist to validate the model because The Dalles tailrace is very dynamic; holding station long enough to collect hydraulic data in the field is nearly impossible and there are overriding safety concerns. The limited prototype data sets that do exist do not include spill since the tailrace is unsafe for navigation under spill conditions. In 2003, a CFD model of the spillway tailrace was developed. Besides collecting hydraulic data from a boat some drogue data exist that has been used to ground truth the physical model and the CFD model. Figures 4.11 shows paths for drogue simulations for releases from Spill Bays 1-6.

The physical model has been used to set spill patterns that produce the best egress conditions, as assessed using dye, confetti, and miniature drogues. Desirable egress conditions in the model are those that maintain dye and confetti in the main river and minimize the amount of dye and confetti in the shallow areas where predators are found. Spill patterns were developed for adults and juveniles at 30, 40, and $64 \%$ spill levels out of total project discharge. The adult pattern was used during the day and was used to maximize the attraction flows to the ladder entrances. The juvenile pattern was used at night to improve juvenile survival.

Beginning in 2000, as mentioned above, the juvenile pattern was employed $24 \mathrm{~h} / \mathrm{d}$ and the spill level was set at $40 \%$ of total river discharge. The juvenile spill pattern was skewed to the north and used 11 to 17 spill bays depending upon total river discharge. A spillway survival test in 2000 highlighted that spillway survival was low and a hydraulic investigation was initiated to get a better handle on mechanical causes for the poor survival. During a model trip to examine the 1:80 general model, a strong lateral flow was observed in the stilling basin. Dye was released on the ogee of Bays 1 and 13; the dye tended to move to the north and exited the spillway at Bays 3 or 4. This lateral flow at the spillway significantly increased the stilling basin retention time. The stilling basin is an extremely turbulent environment where mechanical injury is possible. The concept of lateral flow or movement of juvenile fish from south to north in the stilling basin was verified with balloon-tagged fish, radio-tagged fish, Sensor Fish, and drogues released in Bays 4, 9, and 11 in 2002 and 2003. 


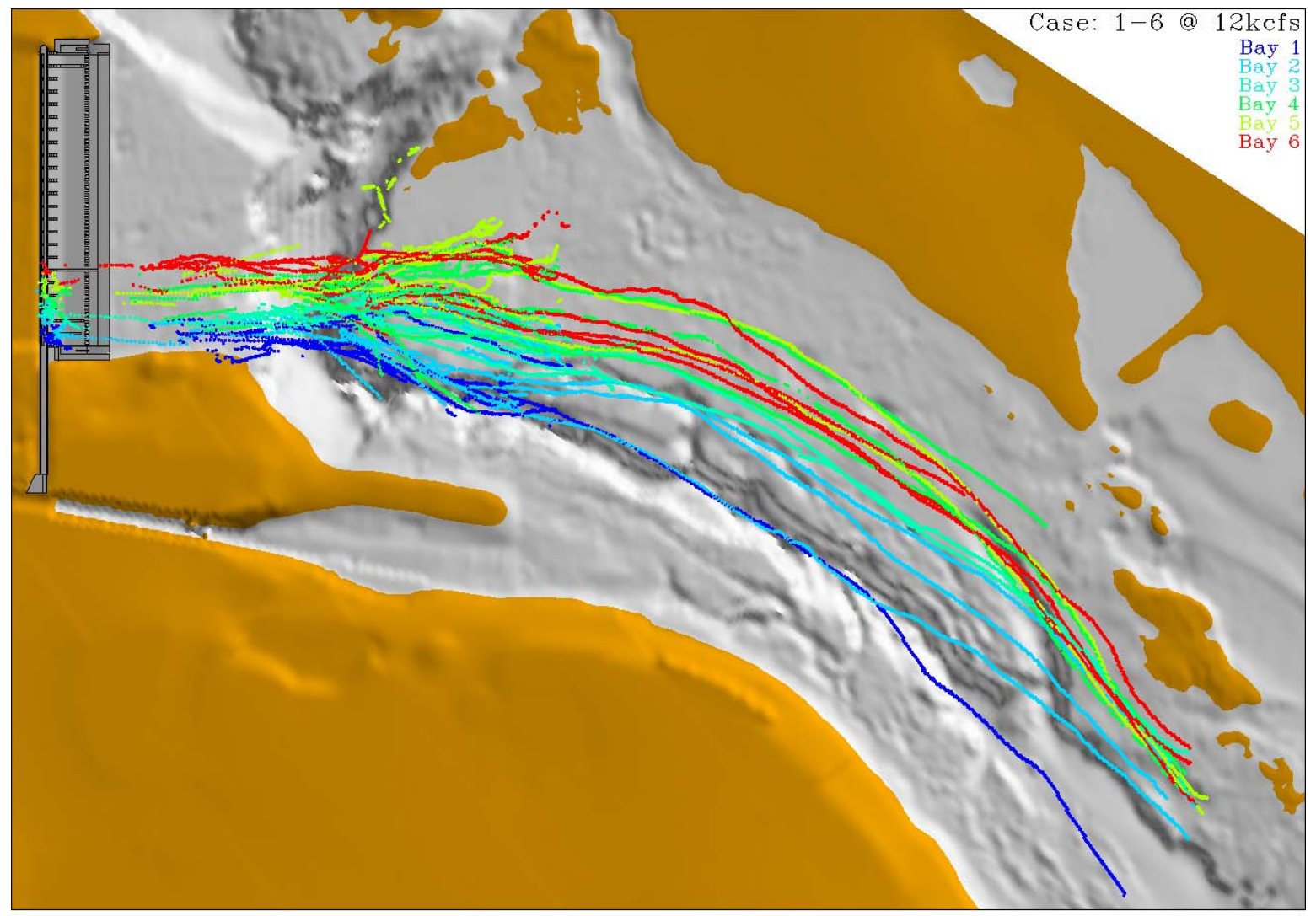

Figure 4.11. Simulated Drogue Travel Paths in the TDA Stilling Basin from a CFD Model (Provided by L. Ebner, USACE Hydraulics)

A spillwall to eliminate the lateral stilling basin flow was evaluated in a physical model at ERDC. The lateral flow was eliminated but spill had to be confined to the northern spill bays and uniformly distributed among the northern bays. The physical model was used to locate the wall, which is between Bays 6 and 7. The spillwall would require significantly higher discharges per bay than was previously used with the juvenile spill pattern. A prototype test was conducted in 2003 to test the concept that eliminating the lateral flow and the high discharge per bay would increase survival. A spill pattern was developed that created similar hydraulic conditions in Bays 2 and 4 to those that would exist if the wall were built. This was accomplished by opening Bay 6 to $26,000 \mathrm{cfs}$ while the adjacent bays were open to $\sim 18,000 \mathrm{cfs}$. Biological results suggested that direct survival would be improved under this condition and the spillwall was constructed and available for the 2004 spill season.

Cook et al. (2006) reported the results from CFD modeling to support the Spillway Improvements Study. The CFD model simulated turbulent surface-free flows in the stilling basin downstream from each spill bay. For example, this CFD model allowed USACE and other agencies to compare flow conditions in the stilling basin with and without the spillwall, as well as to compare tailrace flow patterns for the traditional vs. a bulked spill pattern.

Guensch et al. (2004) studied pressure fluctuations in the stilling basin using pressure sensors (transducers) mounted on the bottom. The mean and standard deviation of static pressure were used to estimate incident velocities at the endsill -15 to $25 \mathrm{fps}$. 
Hydraulic conditions in the powerhouse tailrace channel are unique. Flow exiting the draft tube heads south toward the Oregon shore but interacts with flow that is heading west to exit through the powerhouse exit channel. Local bathymetry in front of some of the draft tubes confounds the flow conditions. The hydraulic conditions created in the powerhouse channel allow for predators along the south shore.

The powerhouse exit channel just south of the spillway controls the water exiting the powerhouse and can cause a backwater effect near the powerhouse. Specifically, the tailwater at the powerhouse can be 18 to 24 inches higher than the tailwater at the spillway, when powerhouse flows exceed 180 to $200 \mathrm{kcfs}$. When powerhouse flows are less than $180 \mathrm{kcfs}$, the tailwater at the powerhouse is typically 2 to 6 inches higher than the tailwater at the spillway. As flow exits the powerhouse exit channel, the main thalweg goes to the north parallel to the spillway and then turns west at the north shore. However, as the water moves through the main thalweg, water moves up and over the shallow areas which include the spillway shelf, the channel along the Oregon shore, and the Bridge Islands.

\subsection{Summary}

In summary, the spillway studies at The Dalles Dam during 2001-2005 showed the following.

- A relationship between spillway passage efficiency and either spill rate or proportion is not evident from hydroacoustic data combined for several study-years and daily radio-telemetry data in 2005, except for radio-tagged subyearling Chinook salmon. For a given spill proportion (e.g., 0.40), daily spill passage efficiency is variable, ranging from 0.25 to 1 .

- A hierarchical multiple regression analysis of the relationship between spill passage efficiency (daily hydroacoustic data) and independent variables for environmental conditions (water temperature and Julian date) and spill operations (spill proportion and spill discharge) shows that water temperature and Julian date alone explain $56 \%$ of the variance in daily spill passage efficiency. Adding spill proportion to the model increased the $\mathrm{R}^{2}$ to $61 \%$. Spill discharge as a variable in the regression model was insignificant.

- The horizontal distribution of fish passage at the spillway during bulk spill in Bays 1 through 6 is skewed toward Bays 5 and 6 . This result is consistent between radio telemetry and hydroacoustic studies. When other bays at the southern edge of the spill pattern, such as Bays 7 and 8 , are opened to pass spill discharge greater than about $120 \mathrm{kcfs}$, noticeable numbers of juvenile salmonids pass in this flow, as indicated by the highest spill effectiveness ratios in those bays out of all open bays at the spillway.

- The 193-ft spillwall in the stilling basin between Bays 6 and 7 was installed in winter 2003/2004 and a new spill pattern was developed to reduce fish passage in bays south of Bay 6 and to stop the lateral movement of water and fish across the stilling basin. Overall survival of fish passing via the spillway after construction of the spillwall is similar to pre-wall conditions.

- Survival estimates from paired releases for radio-tagged fish, averaged over 2004 and 2005 studies (data from Table 4.3), show that survival is higher at Bays 1 through 4 than at Bays 5 and 6 (see the following table). The cause of the lower survival in Bays 5 and 6 has not been definitively identified. 


\begin{tabular}{ccc}
\hline & Bays 1-4 & Bays 5-6 \\
\hline CH 1 & 0.95 & 0.91 \\
CH 0 & 0.94 & 0.84 \\
\hline
\end{tabular}

- Tailrace egress assessments using radio-tagged salmonids and drogues show that travel times from the release point at the dam to an exit station $1.7 \mathrm{~km}$ downstream are generally shortest for fish released in the northern part of the spillway, moderate in the middle, and longest in the south. Also, fish passing the northern part of the spillway are less likely to egress through the island areas below the dam than fish passing in the south spillway.

- The primary predator species in The Dalles Dam tailrace are northern pikeminnow and smallmouth bass. Detections of radio-tagged predators are highest in the shallow island areas below the dam.

- The primary fish injuries at the spillway are on a fish's head according to balloon tag studies. The most prevalent injury types are hemorrhages or ruptures of the eye, torn operculum, and scrapes and bruises. Overall rates of injury related to passage ranged from $0 \%$ to $11 \%$. The injuries to the eye and opercula were attributed to damage from shear forces. Scrapes and bruises to the head were attributed to mechanical contact with solid objects, such as the baffle blocks, the end sill, or rocks.

- During balloon tag studies of direct survival, survival probabilities of Bay 6 fish were 0.959 (SE 0.038) at high tailwater elevation (80 to $83 \mathrm{ft}$ ) and 0.851 (SE 0.030) at low tailwater elevation (76 to $80 \mathrm{ft}$ ). Survival probabilities of fish from Bays 2 and 4 were greater than 0.96 (SE 0.007 to 0.018 ) in all trials. 


\subsection{Sluiceway Studies}

The sluiceway at The Dalles Dam is a functional surface flow outlet ${ }^{\mathrm{a}}$ that has been operated to pass juvenile salmonids for over 35 years. Initial fisheries research established that downstream migrants used the sluiceway and led to a recommendation for "full-time operation of the ice-trash sluiceway at The Dalles Dam with maximum flow" (Michimoto 1971). Current sluiceway operations were established from data collected in the late 1970s and early 1980s (Nichols 1979 and 1980; Nichols and Ransom 1981 and 1982), and substantiated in 2004 and 2005 (Johnson et al. 2005; 2006; Hansel et al. 2004). Sluiceway efficiency estimates (Section 3) were made during the passage studies conducted for the purpose of smolt survival research (Section 7). Studies of fish behavior and hydraulic conditions in the nearfield of the sluiceway entrances $(<30 \mathrm{ft})$ provided a detailed examination of fish response to the sluiceway flow nets in the forebay that was used to interpret sluiceway efficiency data and to generate alternatives for sluiceway improvements. The purpose of this chapter is to synthesize data on hydraulic conditions, entrance configurations, passage efficiencies, and fish behavior at the sluiceway.

\subsection{Hydraulic Conditions}

Water enters the sluiceway channel from the forebay when vertical lift gates are moved off the sill at elevation $151 \mathrm{ft}$. A maximum of six sluice gates can be opened at any time before reaching the hydraulic capacity of the sluiceway channel $(\sim 4,500 \mathrm{cfs})$. Flow into the sluiceway is dependent on forebay elevation and the number and location of open gates. For example, given a forebay elevation equal to $158.4 \mathrm{ft}$ (above mean sea level) and two sluice gate operating conditions, flows over the individual weir gates range from 561 to $1,059 \mathrm{cfs}$ with the highest flows at the west end nearest the sluiceway channel outlet ( Figure 5.1 and Table 5.1). Overall, sluiceway discharge ( 4,500 cfs) is a relatively small proportion of total project discharge $(\sim 2 \%)$.

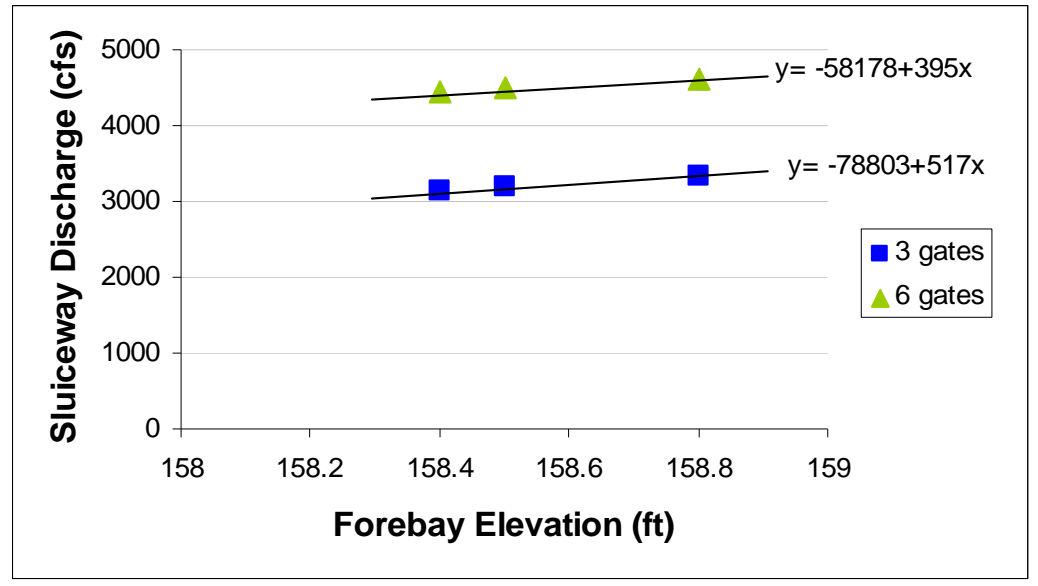

Figure 5.1. Sluiceway Discharge Rating Curves. The curves are based on data from hydraulic calculations provided by USACE-Hydraulics.

\footnotetext{
${ }^{a}$ A surface flow outlet at a hydropower dam is any portal where water flows from the forebay over the dam structure to the river downstream of the dam.
} 
Table 5.1. Hydraulic Calculations for the Sluiceway at The Dalles Dam, Example for Sluice 1 (top) and both Sluice 1 and 18 (bottom). Data provided by USACE Hydraulics assuming reservoir elevation $158.4 \mathrm{ft}$, weir elevation $151 \mathrm{ft}$, and Manning's Roughness 0.014 .

Sluice 1 (3 gates open)

\begin{tabular}{ccccc}
\hline Sluice No. & $\begin{array}{c}\text { Weir No. (order } \\
\text { from d/s) }\end{array}$ & $\begin{array}{c}\text { Flow over weir } \\
(\mathrm{cfs})\end{array}$ & $\begin{array}{c}\text { Water level in } \\
\text { channel (ft) }\end{array}$ & $\begin{array}{c}\text { Ave. velocity } \\
\text { over weir (fps) }\end{array}$ \\
\hline 1 & 1 & 1,059 & 146.6 & 7.2 \\
1 & 2 & 1,051 & 150.7 & 7.1 \\
1 & 3 & 1,029 & 152.0 & 7.0 \\
\hline Total & \multicolumn{5}{c}{ Sluice 1 and 18 (6 gates open) } \\
\hline \multicolumn{7}{c}{ Sluice No. } & Weir No. (order & Flow over weir & Water level in & Ave. velocity \\
& from d/s) & channel (ft) & over weir (fps) \\
\hline 1 & 1 & 1,014 & 149.7 & 6.8 \\
1 & 2 & 876 & 154.0 & 5.9 \\
1 & 3 & 765 & 155.6 & 5.2 \\
18 & 4 & 645 & 156.7 & 4.4 \\
18 & 5 & 589 & 157.2 & 4.0 \\
18 & 6 & 561 & 157.4 & 3.8 \\
\hline Total & & 4,451 & & 5.0 \\
\hline
\end{tabular}

Flow approaches a sluice entrance at an oblique angle relative to the powerhouse, becoming more perpendicular to the dam within 5 to $15 \mathrm{ft}$ of the outlet (Figure 5.2). In cross-section, flow is horizontal (parallel to the surface) until it is near the dam where it goes up to the sluice or down to the turbine intake (Figure 5.3). Flow into the sluiceway has a gradual acceleration until it is over the sill, then water accelerates rapidly into the sluice channel (Figures 5.2 and 5.3). The CFD modeling revealed that nearfield forebay velocities are generally less than $2 \mathrm{fps}$ except very near sluiceway outlets (Figures 5.2 and 5.3). Forebay water velocity is slower at Sluice 18-2 than at Sluice 1-2 (Figure 5.3).

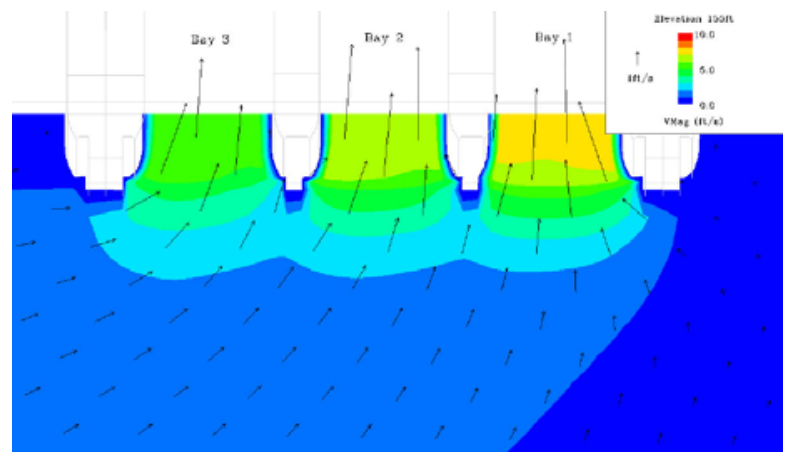

Figure 5.2. Plan View of Water Velocity at Elevation $155 \mathrm{ft}$ at Sluice 2. Data are for a 6-gate configureation (SL 2 and 19). Total sluice flow was 4,580 cfs with total project discharge 207,580 cfs and $40 \%$ spill. (The data are from CFD model runs provided by PNNL Hydrology Group. For scale, the distance between pier noses inside a sluice entrance is $20 \mathrm{ft}$.) 


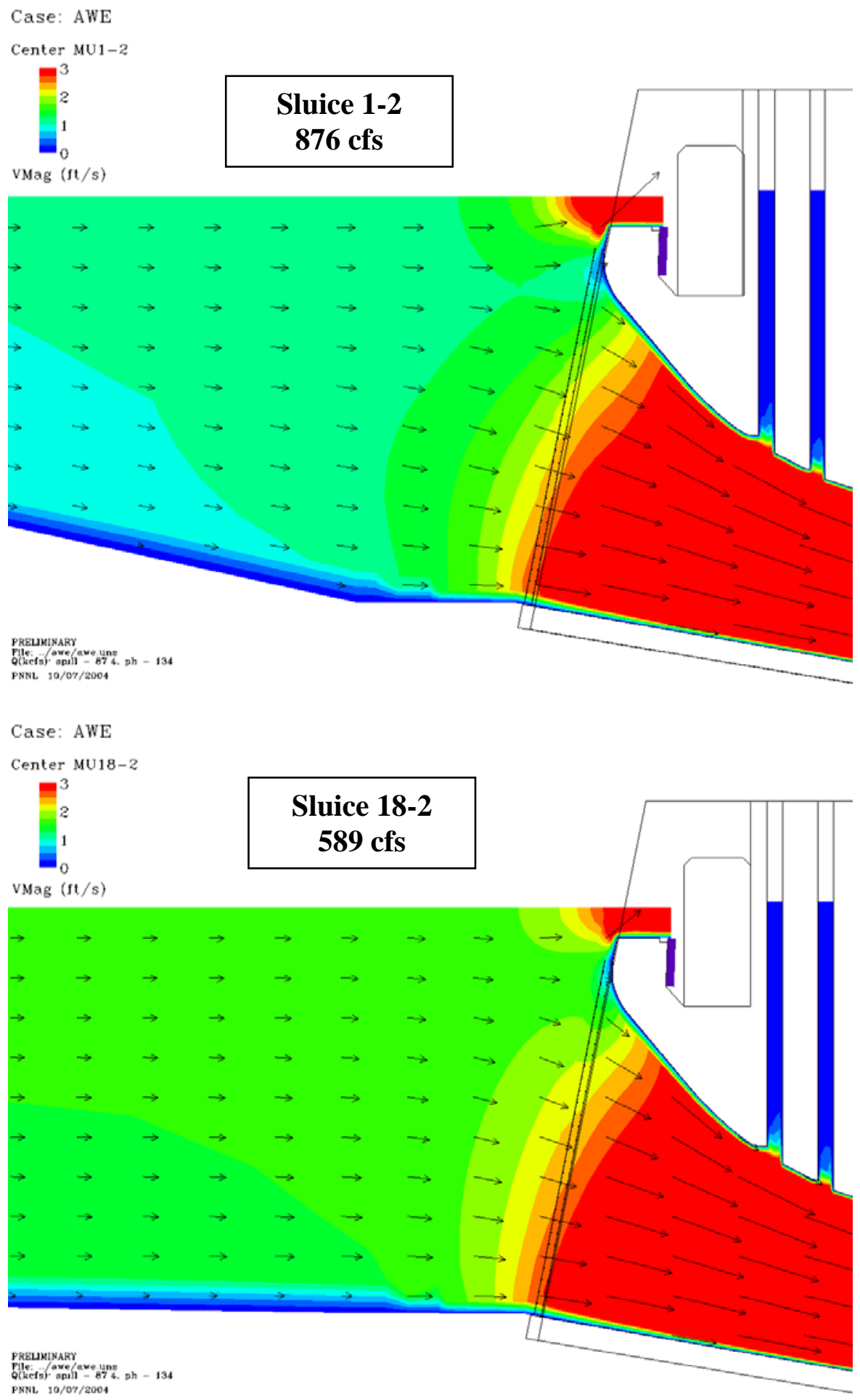

Figure 5.3. Cross-Sectional View of Water Velocity at Two Sluice Entrances, 1-2 (top) and 18-2 (bottom) for the 6-Gate Configuration Described in Table 6.1. (The data are from CFD model runs provided by the PNNL Hydrology Group. For scale, the distance between the water surface and the bottom of the turbine intake is about $100 \mathrm{ft}$.) 


\subsection{Sluiceway Gate Configurations}

Ploskey et al. (2001a) described the fundamental data for the traditional sluiceway configuration of having the west end gates at SL 1-1, 1-2, and 1-3 open continuously from April to December. During outmigrations in 2004 and 2005, alternative sluice gate configurations were evaluated to determine if sluiceway passage efficiency could be improved relative to the traditional operation. The purpose of this section is to summarize the 2004 and 2005 sluiceway configuration studies.

Fish approach and horizontal distribution data from 1997-2002 and new hydraulic calculations of sluiceway inflows in 2003 raised the need to confirm that a west end sluice operation is optimal for both spring and summer outmigrants. For example, in 1997 researchers using radio telemetry first detected about $60 \%$ of the steelhead and $56 \%$ of the yearling Chinook salmon entering the forebay off the eastern end of the powerhouse in spring (Hensleigh et al. 1999). This pattern was consistent with other radio telemetry studies at The Dalles Dam (Sheer et al. 1997; Holmberg et al. 1997; Hansel et al. 2000; Beeman et al. 2005; Hansel et al. 2005). Hydroacoustic studies have shown that the distribution of fish passage at the powerhouse was uniform or skewed toward the west end in spring but skewed toward the east end in summer (Ploskey et al. 2001b; Moursund et al. 2001; Moursund et al. 2002; Johnson et al. 2003). In 2003, engineers determined that the sluiceway at The Dalles Dam was being operated at less than maximum hydraulic capacity when only the three chain gates above Main Unit 1 were open. That is, additional gates could be opened before the maximum hydraulic capacity of the sluiceway channel was reached $(\sim 4,500 \mathrm{cfs})$. Collectively, the biological and engineering studies provided an impetus for renewed sluiceway operations research.

During 2004, an alternative sluice gate configuration that included open east end gates was compared to the traditional configuration during spring and summer. The gate configurations were as follows:

$$
\begin{aligned}
& \text { Sluice } 1=1-1,1-2,1-3 \\
& \text { Sluice } 1+18=1-1,1-2,1-3,18-1,18-2,18-3
\end{aligned}
$$

Sluiceway passage efficiency for the standard operation of three open gates at SL1 was significantly $(\mathrm{P}<0.05)$ less than that for six open gates at SL 1 and SL 18 (Johnson et al. 2005), but the optimum location for open gates was still unclear because there was no clear optimum configuration. Opening the east end sluice contributed 4 percentage points of the total $44 \%$ sluice efficiency at the powerhouse in spring and 7 percentage points of the total $17 \%$ sluice efficiency (re: powerhouse) in summer. In both day and night periods in spring and summer, sluiceway efficiency (re: powerhouse) was significantly $(\mathrm{P}<0.05)$ higher with the West+East treatment than the West only treatment (Johnson et al. 2005). Relative to total project passage, radio telemetry results showed no significant difference between sluiceway passage efficiency or fish passage efficiency between the two sluiceway configurations (Hansel et al. 2005). When both the west and east gates were open, $3 \%$ and $12 \%$ of the radio-tagged yearling and subyearling Chinook salmon, respectively, passed into east end SL 18 gates.

During 2005, more alternative sluiceway gate configurations were evaluated to ascertain the optimum location for open gates. Main Unit 1 was off-line for the entire 2005 study; therefore, the western-most sluice entrance above MU 2 was used. Overall, researchers were interested in determining whether three additional gates in the middle passed more fish than three more gates in the eastern part of the dam. The two sluiceway gate configurations in 2005 were as follows:

Sluice $2+5=2-1,2-2,2-3,5-1,5-2,5-3$ 
Sluice $2+19=2-1,2-2,2-3,19-1,19-2,19-3$.

According to hydroacoustic data, SL $2+5$ had significantly higher sluiceway passage efficiency relative to the powerhouse than SL $2+19$ in both spring $(\mathrm{P}<0.10)$ and summer $(\mathrm{P}<0.05$; Johnson et al. 2006; see Table 5.2).

Table 5.2. Sluiceway Passage Efficiencies (re: powerhouse) for the Configuration Study during 2005 (Data from Johnson et al. 2006)

\begin{tabular}{lcc} 
& Spring & Summer \\
\hline SL $2+5$ & $0.367 \pm 0.023$ & $0.262 \pm 0.012$ \\
SL 2+19 & $0.304 \pm 0.016$ & $0.169 \pm 0.009$ \\
\hline
\end{tabular}

For a given location, sluiceway passage efficiency at that particular sluice/turbine combination [e.g., SL 2 efficiency $=$ SL 2/(SL $2+$ MU 2)] was higher at SL 2 and SL 5 than at SL 19 during both spring and summer ( $95 \%$ confidence intervals were within approximately $5 \%$ of the estimate; see Table 5.3 ).

Table 5.3. Sluiceway Passage Efficiencies (re: individual locations) for the Configuration Study during 2005 (Data from Johnson et al. 2006)

\begin{tabular}{lcc} 
& Spring & Summer \\
\hline SL 2 & 0.916 & 0.622 \\
SL 5 & 0.674 & 0.876 \\
SL 19 & 0.462 & 0.442 \\
\hline
\end{tabular}

According to radio telemetry data, there were no significant differences between sluice treatments for sluiceway passage efficiency or fish passage efficiency relative to the project as a whole (Hansel et al. 2007). As in 2004, most ( $>85 \%$ ) of the radio-tagged fish passing into the sluiceway did so at the west end gates (SL 2). An important difference between the hydroacoustic and radio telemetry studies is that the former assessed sluiceway performance relative to the powerhouse while the latter studied the sluiceway relative to the entire project.

Although data showed that some juvenile salmonids passed into the experimental east end sluice entrances in 2004 (SL 18) and 2005 (SL 19), the majority (> 62\%) of fish passage into the sluiceway occurred through the west gates in 2004 (SL 1) and in 2005 (SL 2). This was true in both spring and summer in both 2004 and 2005. The hypothesized effect of east-end sluice gates on total sluiceway passage, especially for subyearling migrants in summer, was equivocal for the operations that were tested in 2004 and 2005 because of the relatively low inflow ( 1,700 cfs) and corresponding small flow net for the sluice entrances at the east end of the dam. Therefore, the optimum location for open sluice gates remains a question, as shown by sluiceway efficiency data from 1999-2005 (Figure 5.4). No single sluiceway operation stands out as the best in terms of efficiency relative to total powerhouse passage. Extremes for spring and summer were observed in 2001, a drought year with little spill (Figure 5.4). Certainly the three gates above the western-most operating main turbine unit should be opened and, given the apparent advantage of six over three gates, researchers suggested opening three more gates at MU 8 where turbine passage rates are relatively high (Johnson et al. 2006).

Patterns relating sluiceway passage efficiency relative to the powerhouse to various operational parameters, such as total river, powerhouse, and spillway discharge, were not evident in hydroacoustic 
data from 1999, 2001, 2002, 2004, and 2005 (Figure 5.5). The USACE might consider breaking these data down into finer temporal increments.

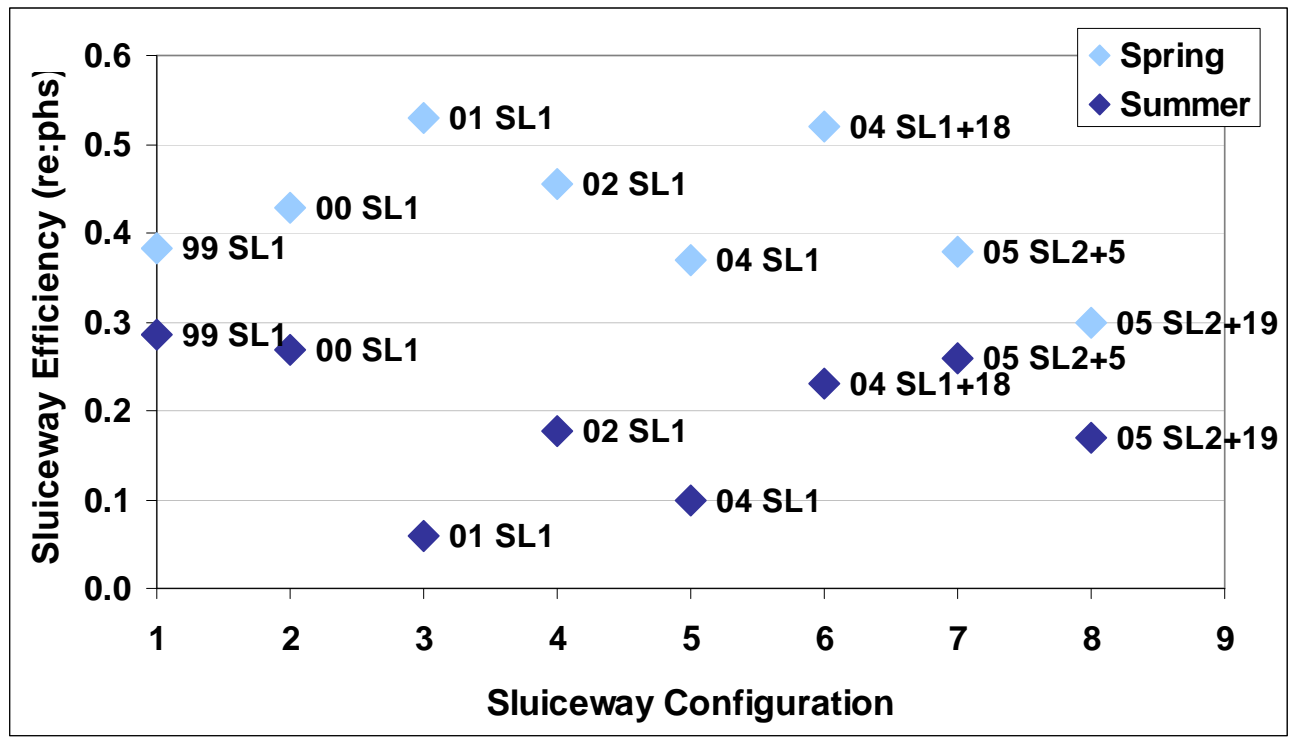

Figure 5.4. Sluiceway Efficiency (re: powerhouse) for Configurations Tested 1999-2005. (Data are from hydroacoustic evaluations.)
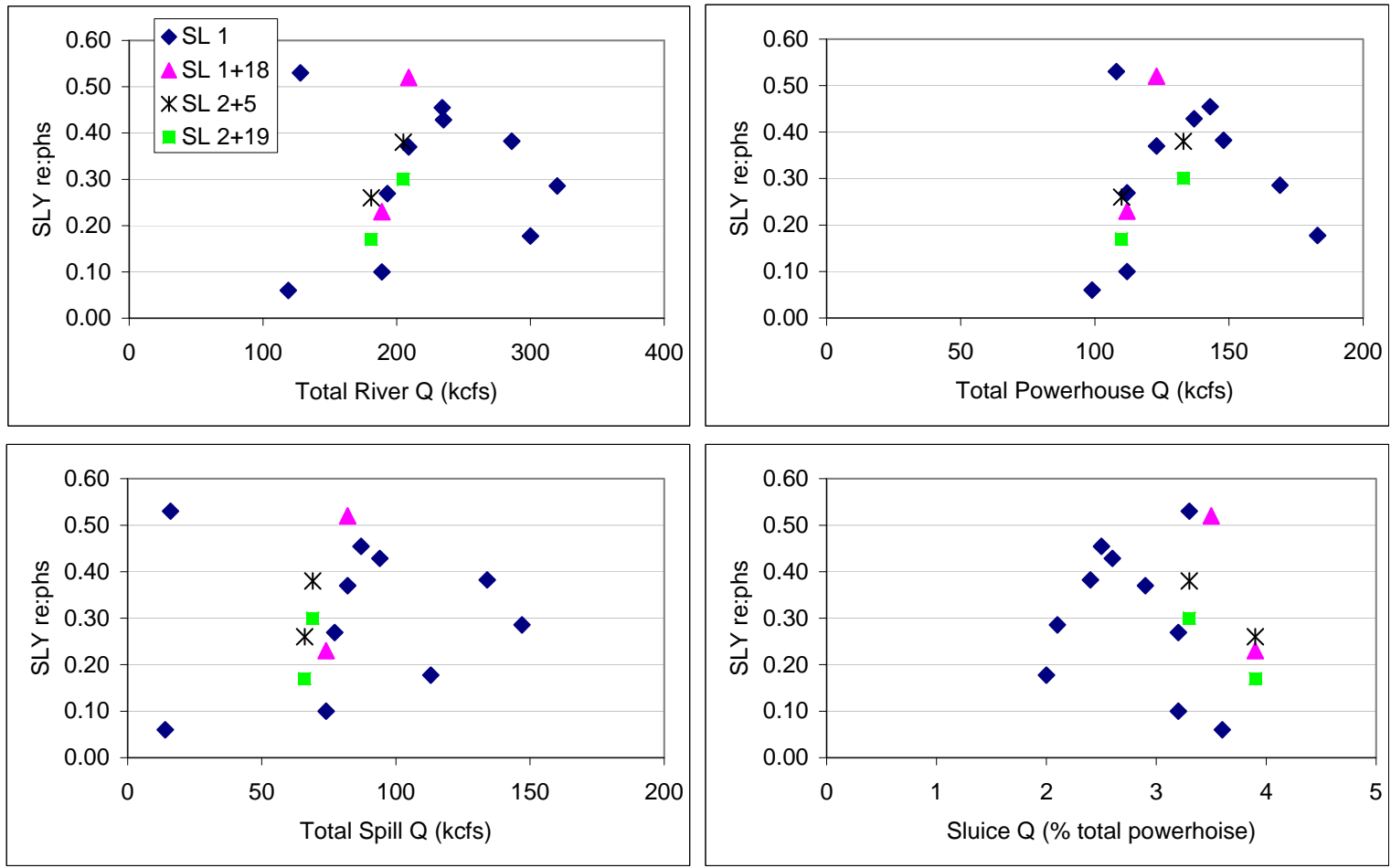

Figure 5.5. Sluiceway Efficiency (re: powerhouse) by Total River, Powerhouse, and Spillway Discharge and the Percentage of Sluiceway Out of Powerhouse Discharge for Configurations Tested 1999-2005. (Data are from hydroacoustic evaluations.) 


\subsection{Fish Behavior in the Sluiceway Nearfield}

In 2000, 2001, 2004, and 2005, researchers studied smolt behavior in the sluiceway nearfield $(<10$ $\mathrm{m})$ to better understand why the sluiceway is relatively efficient at passing juvenile salmonids. Their objectives generally were to 1) track smolt movements in the near field of sluice entrances; 2) estimate state $^{\mathrm{b}}$ proportions and estimate fate ${ }^{\mathrm{c}}$ probabilities; and 3) assess specific premises about smolt movements in relation to The Dalles sluiceway outlets. A sonar tracker was used during studies in 2000 and 2001 (Johnson et al. 2001; Hedgepeth et al. 2002a,b, respectively). An acoustic camera was used in 2004 and 2005 (Johnson et al. 2005, 2006, respectively). Tens to hundreds of thousands of fish were tracked in samples of smolt movements in the near field of the sluiceway entrances.

In general, smolt movements were complex and multi-directional; fish were not moving through the sample volumes in a fixed, consistent direction. Holding was not observed at the sluice entrances but was seen in front of the upper portion of turbine intake entrances (researchers only sampled the upper $6 \mathrm{~m}$ of the intake) and was especially prevalent at night off the west pier nose by the MU 1-1 intake. Overall, the trend in movement was westward and toward the dam, e.g., Hedgepeth et al. (2002a) reported that in the $\mathrm{X}$-dimension parallel to the powerhouse, $56 \%$ moved west out of total west + east, and in the Y-dimension perpendicular to the powerhouse, $59 \%$ moved toward the dam out of total toward+away. Movements to the west, toward the dam, and upward were 3\%-5\% stronger during day than night. When moving toward the dam, smolts were more likely to also be moving up than down; but when moving away from the dam, they were more likely to move down than up.

The most dramatic effect on fish movements in front of the sluiceway, however, was caused by spill. For example, when water was spilled during the 2001 study, the proportion of fish moving westward toward the spillway was $63 \%$ compared to $49 \%$ during no spill. Also, movement proportions toward the dam and upward were $2 \%-3 \%$ higher during spill than during no spill.

By definition, the fish entrainment zone of the sluiceway was represented by probabilities greater than 0.9 from the Markov chain analysis of passage out the sluice side of the sonar tracker's sample volume (Johnson et al. 2004). The analysis assumed that movement toward the sluiceway represented ultimate fish entrainment into the sluiceway. Using daytime data from 2000 as an example, there was a high (> $90 \%$ ) probability of movement out of the sample volume adjacent to the entrance at Sluice 1-1 from cells within 7-10 ft deep and about 20-26 ft out from the entrance (Figure 5.6). Cells in the figure show probabilities of passage from a particular cell out the sluice side of the sample volume. The sluiceway zone of influence (ZOI; zone where the probability of passage toward the sluice entrance was $>90 \%$ ) extended more eastward than westward of the entrance to Sluice 1-1. The ZOI decreased dramatically with increasing depth beyond $10 \mathrm{ft}$. In the 2000 study, the ZOI of Sluice 1-1 was 16-23 ft wide and extended 20-26 ft from the dam in the surface layer 7-10 ft deep. The total volume of the sluiceway ZOI in the sampling zone was $1,535 \mathrm{ft}^{3}$ during the day. The 2000 results were generally typical of the other studies as well, although the sluiceway ZOI varied by day/night and location/inflow.

\footnotetext{
${ }^{\mathrm{b}}$ A state is a fish movement pattern in three dimensions (X, Y, Z). States are expressed as proportions, i.e., the proportion of fish moving in a particular direction(s).

${ }^{c}$ A fate is where smolts exit the sample volume. Fates are expressed as probabilities of passage into a particular area, e.g., the sluiceway.
} 


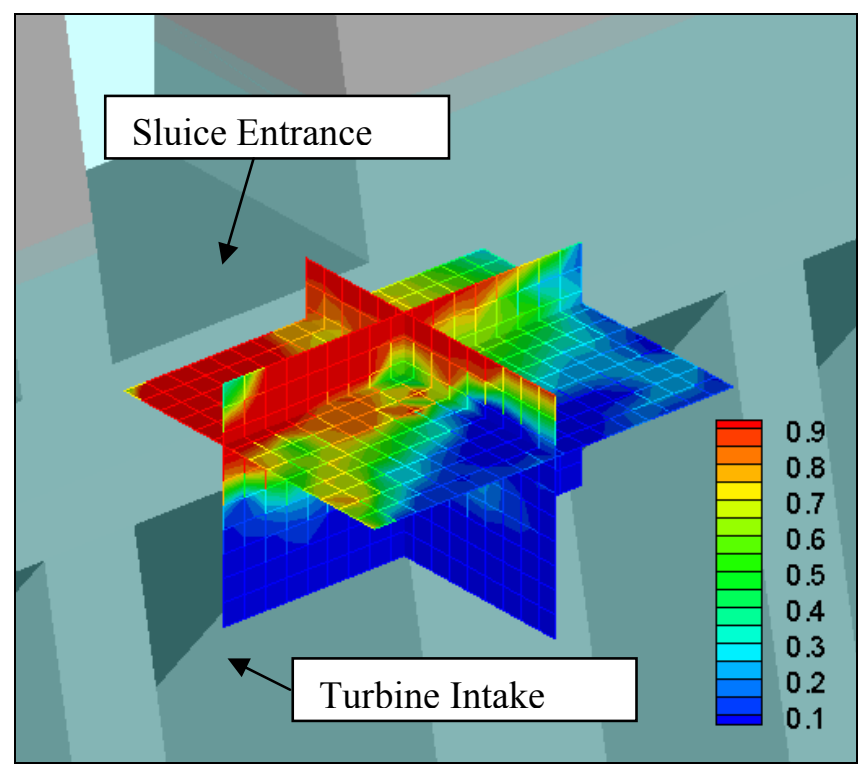

Figure 5.6. Three-Dimensional Presentation of the Sluice Fate for Selected Inner Slices of the Sample Volume. The sluice fate is the probability of exiting the sluice side of the sample volume. The three slices are located on the centerline of Sluice 1-1 (x-dimension), $16 \mathrm{ft}$ from the dam (y-dimension), and $5 \mathrm{ft}$ deep (z-dimension). (Data are from Johnson et al. 2004.)

Differences in the fish entrainment zone for the sluiceway between day and night and location/inflow were evident, as shown in the 2005 study (Johnson et al. 2006). Plotting the sluiceway fate as a function of distance from the dam (pier edge at elevation $158 \mathrm{ft}$ ) for each combination of day/night and location, the ZOI varied from 0 to $17 \mathrm{ft}$ (0-5.2 m; Figure 5.7). The extent of the fish entrainment zone was similar to previous results that visually showed the limit of the ZOI at about $13 \mathrm{ft}$. The ZOI was spread more to the east than to the west (Figure 5.7), generally following water flow patterns into the sluiceways (Johnson et al. 2005). The highest sluiceway passage in spring at SL 2 corresponded to a ZOI of 7-17 ft and is less than the 20-26 ft ZOI reported in Johnson et al. (2004) at SL 1-1. The ZOI decreased at both sluiceway entrances in summer.

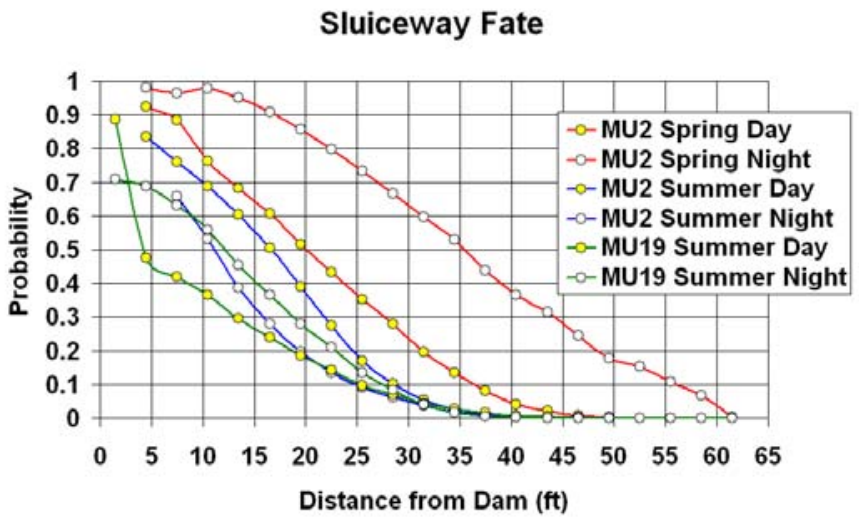

Figure 5.7. Fish Passage Probabilities at The Dalles Dam SL 2 (= MU 2) and SL 19 (= MU 19) in 2005. Expressed as a function of distance from the dam (pier nose edge at elevation $158 \mathrm{ft}$ ). (Data are from Johnson et al. 2006) 


\subsection{Summary}

The key findings from the sluiceway studies during 2001-2005 at The Dalles Dam may be summarized as follows:

- Maximum sluiceway discharge is $\sim 4,500 \mathrm{cfs}$ and depends on forebay elevation and the number and location of open gates. The closer the gate is to the flow control point at the west end of the sluiceway channel, the higher the discharge for a given gate opening. Sluiceway discharge rating curves for 3-gate (1-1, 1-2, and 1-3) and 6-gate (1-1, 1-2, 1-3, 18-1, 18-2, and 18-3) operations are

3-gate: Sluiceway Q $(\mathrm{cfs})=-78803+517 *$ Forebay Elevation $(\mathrm{ft})$

6-gate: Sluiceway $\mathrm{Q}(\mathrm{cfs})=-58178+395 *$ Forebay Elevation $(\mathrm{ft})$.

- Flow approaches a sluice entrance at an oblique angle relative to the powerhouse, becoming more perpendicular as water moves within $5-15 \mathrm{ft}$ of an outlet, depending on location. Flow into the sluiceway has a gradual acceleration until it goes over the sill, then water accelerates rapidly into the sluice channel. The CFD modeling revealed that nearfield forebay velocities are generally less than 2 fps, except near sluiceway entrances.

- Different sluiceway gate configurations were evaluated in 2004 and 2005. Juvenile salmonids passed into the experimental east end sluice entrances in 2004 (SL 18) and 2005 (SL 19), but the majority (> $62 \%$ ) of fish passage into the sluiceway occurred in both spring and summer through the west gates in 2004 (SL 1) and in 2005 (SL 2). This result was evident in both the hydroacoustic and radio telemetry studies. The hypothesized effect of east-end sluice gates on total sluiceway passage, especially for subyearling migrants in summer, was equivocal for the operations tested in 2004 and 2005 because of the relatively low inflow ( 1,700 cfs) and corresponding small flow net for the sluice entrances at the east end of the dam. Opening west end gates is a must, but the optimum location for other open sluice gates remains a question because no single sluiceway operation stands out as the best in terms of efficiency relative to total powerhouse passage.

- Fish behavior in the nearfield ( $<30 \mathrm{ft})$ of the sluiceway is complex and variable. At Sluice 1 at the west end of the dam, the predominate movement directions are generally to the west toward the spillway and to the south toward the sluiceway. Juvenile salmonids are surface-oriented and will move upward in the water column to pass into the sluiceway. Some fish hold in front of the sluice sill, exhibiting positive rheotaxis, orienting and swimming into the flow.

- The zone of entrainment (defined as the distance from the sluiceway where the probability of moving toward the sluiceway is greater than $90 \%$ ) is approximately $20 \mathrm{ft}$. This zone is larger for spring than summer migrants and larger at west than east gates. 


\subsection{Turbine Studies}

At The Dalles Dam, intake screens and occlusions have been investigated as means to reduce entrainment of juvenile salmonids into turbines. Although the intake screen research occurred prior to 2001, it is presented in this report for completeness because it was not covered by Ploskey et al. (2001a). Similarly, we include intake occlusion research conducted prior to 2001 that was not reviewed by Ploskey et al. (2001a), along with data from the 2001 and 2002 intake occlusion studies.

\subsection{Intake Screens}

The USACE has designed a turbine intake screen juvenile bypass system for The Dalles Dam, analogous to that of other JBSs at other USACE mainstem Columbia and Snake River dams. The Dalles Dam is distinct from the others, however, in that turbine intakes screens have not been installed at the TDA powerhouse because a suitable outfall location was not evident, fish guidance efficiencies for subyearling Chinook salmon were not acceptable, and the cost to outfit 66 intakes would be high. The engineering design for an extended-length intake screen system has been archived. Regardless, fish passage research for the screen effort provided some useful findings that are important to capture in this synthesis report.

Submersible traveling screens and extended-length screens were tested at The Dalles Dam during 1985-1986 and 1993-1995, respectively. These studies (e.g., Absolon et al. 1995) usually involved fyke nets deployed behind the screens to estimate the number of unguided fish and dip nets in the gatewells to estimate numbers of guided fish. We report just the 1993-1995 screen studies, because they examined state-of-the-art technology, the extended-length screens. One study (Nestler and Davidson 1995) used low-light video cameras attached to various locations on different screens to estimate impingement rates and relate these data to hydrodynamic conditions.

Extended-length submersible bar screens (ESBS) and extended-length submersible traveling screens (ESTS) had 50\%-100\% higher fish guidance efficiency (FGE) than regular submersible traveling screens during a test in 1993 (Table 6.1). Yearling Chinook salmon FGE was greater than $60 \%$ for the extendedlength screens. The best FGE observed for subyearling Chinook salmon was 59\%. The goal of 70\% FGE was not met for subyearling Chinook salmon.

Table 6.1. Mean Fish Guidance Efficiency Estimates (\%) for Prototype Intake Screens at The Dalles Dam. STS = submersible traveling screen; ESBS = extended-length submersible bar screens; ESTS $=$ extended-length submersible traveling screens.

\begin{tabular}{llcccl}
\hline Year & Species & STS & ESBS & ESTS & Source \\
\hline \multirow{2}{*}{1993} & CH 1 & 44 & 73 & 60 & Brege et al. 1994 \\
& CH 0 & 23 & 59 & 51 & \\
& CH 1 & --- & 69 & 65 & Absolon et al. 1995 \\
& CH 0 & --- & 54 & 47 & \\
\hline
\end{tabular}

As a secondary objective, Absolon et al. (1995) assessed the horizontal distribution of passage at the powerhouse. Proportions of total powerhouse net capture rates at the sampled intake at the west end of the dam (MU 2-2) were higher than at the sampled intakes at the center (MU 12-2) and east end (MU 172 ) for both yearling $(61,25$, and $14 \%$, respectively) and subyearling Chinook salmon $(65,26$, and $9 \%$, respectively). 
Nestler and Davidson's (1995) underwater video study of fish behavior and impingement at prototype extended-length screens at The Dalles Dam showed that impingement rates, detections at the upstream face of the screen, and the standard deviation of the approach angle of water currents were lower for the ESTS than for the ESBS. The authors surmised that this may have been due to more turbulent hydrodynamic conditions immediately upstream of the ESTS than the ESBS. Fish may have detected this turbulence and responded by swimming away from the screen.

\subsection{Intake Occlusion Plates}

Intake occlusion plates were evaluated at The Dalles Dam to determine if blocking the upper portion of the turbine intakes at the trash racks might significantly reduce turbine entrainment. Turbine intake occlusion tests were conducted in 1995, 1996, 2001, and 2002. Physical scale (1:25) and CFD models were used to investigate flow conditions and select the shapes and dimensions of the occlusion structures.

\subsubsection{Biological Results}

In 1995, the upper $22 \mathrm{ft}$ of the trash racks at MU 1 and MU 2 were occluded, i.e., blocked to El. $120 \mathrm{ft}$ mean sea level. The steel plate occlusions were moved in and out daily according to a randomized block experimental design. Passage rates at the turbine intakes behind the occlusions were not reported (Nagy and Shutters 1995), so it is not possible to ascertain the effects of the occlusions on turbine entrainment. The authors noted that passage at Sluice 1-2 was consistently higher than that at Sluice 2-2.

In 1996, the upper half of the trash racks at MU 1-5 and Fish Units 1-2 were occluded, i.e., blocked to El. $100 \mathrm{ft}$ mean sea level. Again, the steel plate occlusions were moved in and out according to a randomized block experimental design. The hydroacoustic evaluation of the effects of the intake occlusions, however, was inconclusive because the principle of equivalent acoustic detectability (Johnson 2000) among sample locations and study conditions was not met (BioSonics 1997).

In 2001, turbine intake occlusion plates with extensions to form "J-occlusions" (Figure 6.1) were deployed at MU 1-4. The purpose of the extensions was to deepen the forebay flow net for turbine discharge with the intent to entrain fewer surface-oriented juvenile salmonids. Various shapes of blocked trashracks for The Dalles Dam were studied in physical and numerical models (e.g., ENSR 2001). A J-

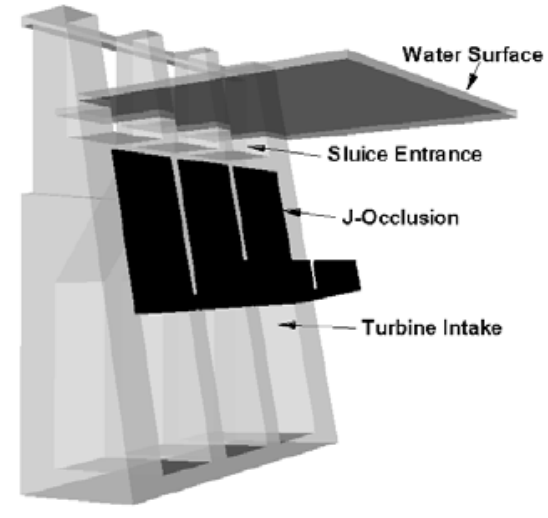

Figure 6.1. J-Occlusions at TDA shaped blockage appeared to be the most effective in creating flow conditions thought favorable for collection of juvenile fish in the ice and trash sluiceway. The experimental design called for the Jocclusions to be moved in and out according to a randomized block schedule. Comparison of fish passage rates with and without the J-occlusions, however, was not possible because of logistical difficulties lifting and lowering the occlusions. Furthermore, 2001 was an extremely low-water year with sporadic spill operations at The Dalles Dam. These events caused engineers, biologists, and dam operators to focus on 2002 for a definitive test of the $\mathrm{J}$ occlusions.

In 2002, the J-occlusions at MU 1-4 were flawlessly moved in and out for the purpose of the evaluation during spring and summer juvenile salmonid outmigration periods (April 20 to July 12). At 
FU 1-2 and MU 5, occlusions without J-extensions were fixed in position. The randomized blocks were 6 days long with two 3-d treatments (IN and OUT). Main Units 1-5 were block loaded at about 13,500 cfs per unit during the entire study period, although this was not a typical operation pattern. Spill was continuous during the study at about $40 \%$ of total project discharge. The evaluation involved both radio telemetry and hydroacoustic techniques.

The hydroacoustic results of the J-occlusion analysis showed no significant differences between the IN and OUT treatments for any of the response variables, except MU 1-4 turbine passage at night (OUT > IN; Table 6.2; Johnson et al. 2003). In summer, the IN/OUT differences were significant for MU 1-4 passage, but the response variable means showed a negative J-occlusion effect. For total project fish passage efficiency, there were no significant differences $(\mathrm{P}>0.53)$ between $\mathrm{J}$-occlusion treatments. Therefore, it appears from the hydroacoustic data that the J-occlusions did not enhance smolt protection at The Dalles Dam in 2002 (Table 6.2).

Table 6.2. Results of the Hydroacoustic Evaluation of J-Occlusions at TDA during 2002. Metrics are mean 3-d passage rates at MU 1-4 turbine intakes and sluiceway efficiencies relative to MU 14 (SLY 1-4). Modified from Johnson et al. (2003; p.iii). Bolded values represent statistically significant differences at the $95 \%$ level.

\begin{tabular}{lccccccccc}
\hline & & \multicolumn{4}{c}{ Spring } & \multicolumn{4}{c}{ Summer } \\
\cline { 3 - 10 } & & \multicolumn{2}{c}{ Day } & \multicolumn{2}{c}{ Night } & \multicolumn{2}{c}{ Day } & \multicolumn{2}{c}{ Night } \\
\hline Metric & J-Occl's & Mean & P-value & Mean & P-value & Mean & P-value & Mean & P-value \\
\hline MU 1-4 & IN & 55,886 & 0.130 & $\mathbf{4 5 , 5 9 1}$ & 0.027 & $\mathbf{8 2 , 3 4 7}$ & 0.014 & $\mathbf{7 4 , 3 4 2}$ & 0.002 \\
& OUT & 84,952 & & $\mathbf{9 4 , 4 8 3}$ & & $\mathbf{3 4 , 9 7 3}$ & & $\mathbf{2 9 , 4 4 9}$ & \\
\hline \multirow{2}{*}{ SLY 1-4 } & IN & 0.44 & 0.187 & 0.56 & 0.389 & 0.44 & 0.087 & 0.34 & 0.084 \\
& OUT & 0.56 & & 0.52 & & 0.65 & & 0.44 & \\
\hline
\end{tabular}

The radio telemetry analyses of J-occlusion effects focused on data from tagged fish detected at MU 1-4 and their subsequent passage at the sluiceway, spillway, and turbines (Hausmann et al. 2004). Passage efficiencies were estimated relative to the total for all passage routes for tagged fish detected at MU 1-4. The results for sluiceway efficiency (SLY) showed no significant difference between Jocclusion treatments for yearling Chinook salmon (Table 6.3). There was a significant difference in SLY for steelhead during the day (OUT > IN), but not during the night. During the summer study period, subyearling Chinook salmon SLY was significantly different between treatments during night (IN > OUT), but not during the day. In sum, the radio-telemetry data for sluiceway efficiency indicated no advantage of the J-occlusions except for subyearling Chinook salmon at night (Table 6.3). 
Table 6.3. Sluiceway Passage Efficiency (SLY) for Radio-Tagged Fish at TDA in 2002. Modified from Hausmann et al. (2004; p.7). CH 1 = yearling Chinook salmon; ST = steelhead; $\mathrm{CH} 0=$ subyearling Chinook salmon. Confidence intervals (95\%) are in the parentheses. Bolded values represent statistically significant differences at the $95 \%$ level.

\begin{tabular}{lcccc}
\hline Day/Night & J-occl's & CH 1 & ST & CH 0 \\
\hline Day & IN & 0.40 & 0.52 & 0.28 \\
& & $(0.32-0.49)$ & $(0.45-0.59)$ & $(0.21-0.36)$ \\
& OUT & 0.29 & 0.65 & 0.20 \\
& & $(0.24-0.35)$ & $(0.58-0.71)$ & $(0.15-0.27)$ \\
\hline Night & IN & 0.66 & 0.48 & $\mathbf{0 . 5 4}$ \\
& & $(0.55-0.76)$ & $(0.36-0.60)$ & $(0.43-0.64)$ \\
& OUT & 0.62 & 0.60 & $\mathbf{0 . 3 3}$ \\
& & $(0.51-0.73)$ & $(0.46-0.73)$ & $(0.24-0.42)$ \\
\hline
\end{tabular}

Hausmann et al. (2004) also reported estimates of fish passage efficiency and spill efficiency for tagged fish detected at MU 1-4. These data are useful because, while the purpose of the J-occlusions was to decrease turbine passage at MU 1-4, any decrease in turbine passage would necessarily have to correspond to an increase in sluiceway or spillway passage or both. For brevity, we included the spillway passage data along with the sluiceway data above. Spillway passage efficiency was significantly higher with the J-occlusions IN than OUT during daytime for yearling Chinook salmon and steelhead (Table 6.4). Significant differences in SPY were not observed during night or for subyearling Chinook salmon. Therefore, the radio-telemetry data showed some positive effects on sluiceway and spillway efficiency from the J-occlusions, but the effects were inconsistent among species and time of day (Tables 6.3 and $6.4)$.

Table 6.4. Spillway Passage Efficiency (SPY) for Radio-Tagged Fish at TDA in 2002. Modified from Hausmann et al. (2004; p.7). CH 1 = yearling Chinook salmon; ST = steelhead; $\mathrm{CH} 0=$ subyearling Chinook salmon. Confidence intervals (95\%) are in the parentheses. Bolded values represent statistically significant differences at the $95 \%$ level.

\begin{tabular}{lcccc}
\hline Day/Night & J-occl's & CH 1 & ST & CH 0 \\
\hline Day & IN & $\mathbf{0 . 4 1}$ & $\mathbf{0 . 4 3}$ & 0.43 \\
& & $(0.25-0.58)$ & $(0.36-0.50)$ & $(0.30-0.56)$ \\
& OUT & $\mathbf{0 . 1 3}$ & $\mathbf{0 . 2 9}$ & 0.21 \\
& & $(0.07-0.23)$ & $(0.23-0.36)$ & $(0.12-0.32)$ \\
\hline Night & IN & 0.15 & 0.31 & 0.21 \\
& & $(0.08-0.23)$ & $(0.21-0.43)$ & $(0.09-0.38)$ \\
& OUT & 0.07 & 0.27 & 0.04 \\
& & $(0.03-0.13)$ & $(0.16-0.41)$ & $(0.05-0.13)$ \\
\hline
\end{tabular}

A final biological observation concerns predator fishes. Using an acoustic camera, researchers saw predator fishes at MU 1 and 2 staging near the sluiceway entrance just below the sill or near the pier noses (Johnson et al. 2003). At MU 3 and 4, predators were observed roaming back and forth along the powerhouse near the intake trashracks with J-occlusions OUT or near the occlusion plates with Jocclusions IN. Predator detection rates were similar between seasons and IN and OUT treatments. Thus, predators were present in the forebay near the face of the dam irrespective of the J-occlusions. 


\subsubsection{CFD Modeling}

Results from CFD modeling showed differences in forebay flow regimes with and without the Jocclusions in place (Johnson et al. 2003). Flow into turbine intakes at The Dalles Dam was slower and flatter with the J-occlusions OUT than IN (Figure 6.2). With the J-occlusions in place, water was drawn downward from the upper water column (El. $120 \mathrm{ft}$ and below) in the forebay above the bottom of the Jextensions. Velocities were 3 to $4 \mathrm{fps}$ around the bottom of the J-extension. Without the J-occlusions, water in this same region went directly toward the intake. Water velocities generally increased downstream of the trashracks. Thus, the J-occlusions apparently did not deepen the forebay flow net for the turbines as intended; rather, the J-occlusions created stronger downward currents from surface waters toward and into the turbine intakes.
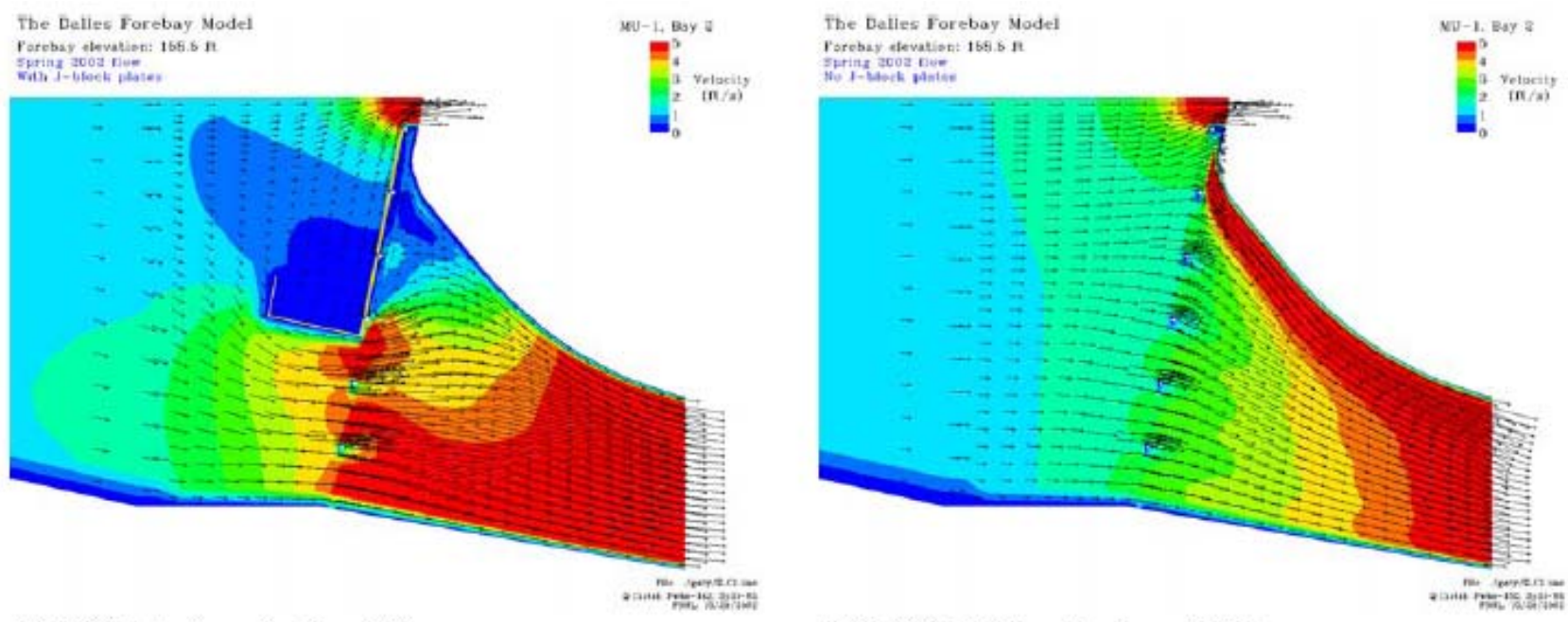

(a) MU 1-2, J-occlusions IN

(b) MU 1-2, J-occlusions OUT
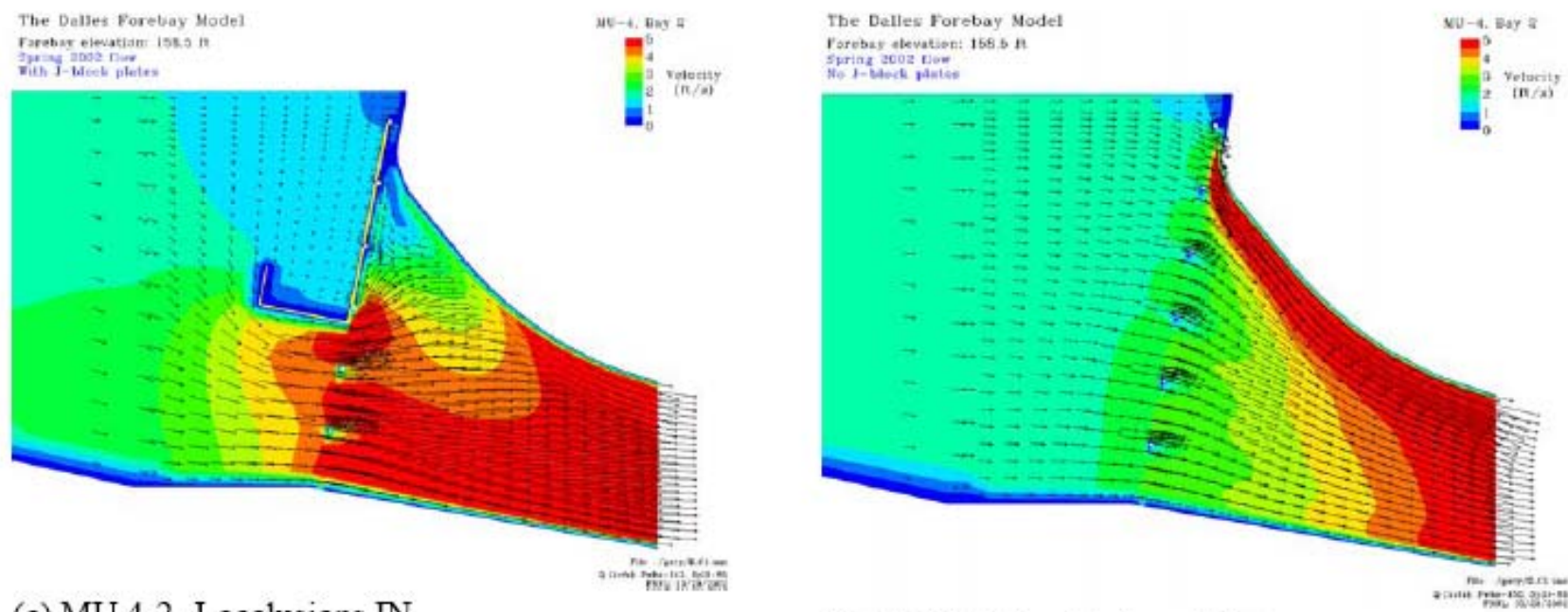

(c) MU 4-2, J-occlusions IN

(d) MU 4-2, J-occlusions OUT

Figure 6.2. Sectional View of Water Velocity at the Centerlines of MU 1-2 and MU 4-2 with JOcclusions IN and OUT. (The model output and figures were provided by J. Serkowski, PNNL Hydrology.) 
Block loading main units 1-5 instead of the usual skip loading affected forebay velocity patterns (Figure 6.3). The difference in velocity magnitude between the two patterns was evident across the entire forebay from the powerhouse to the Washington shore.

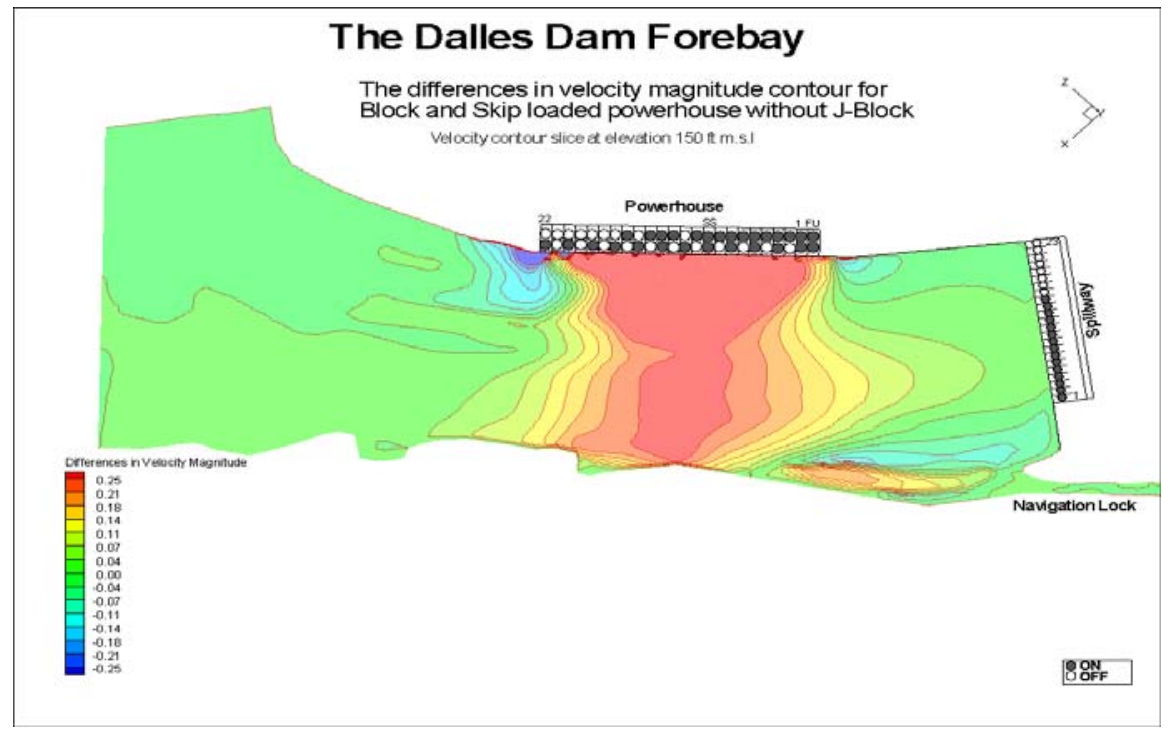

Figure 6.3. CFD Model Output for The Dalles Dam Forebay Showing the Effects of Block Loading Main Units 1-5 on Forebay Velocities. Data are the differences in the velocity magnitude between block and skip loading turbine operation patterns. (Figure provide by L. Ebner, USACE hydraulics.)

\subsection{Summary}

The turbine passage studies at The Dalles Dam focused on intake screens and occlusions. The main results can be summarized as follows:

- Fish guidance efficiency for yearling Chinook salmon was greater than $60 \%$ for the extended-length screens, but the best FGE observed for subyearling Chinook salmon was 54\%.

- The most definitive study of J-occlusions occurred in 2002. The results did not indicate a clear, definite advantage of deploying intake occlusion plates for the purpose of smolt protection at TDA.

- During spring 2002, the hydroacoustic and radio-telemetry data usually both showed no significant differences between IN/OUT treatments for various response variables.

- During summer 2002, the hydroacoustic study showed negative effects in terms of MU 1-4 turbine passage during day and night. On the other hand, the radio telemetry study demonstrated positive effects in terms of sluiceway efficiency during night, but all other statistical comparisons were insignificant $(\mathrm{P}>0.05)$.

- The CFD data indicated that the water current patterns in the forebay were stronger downward toward the turbines with the J-occlusions IN than OUT.

- Block loading MU 1-5 during the 2002 J-occlusion evaluation affected forebay flow patterns by creating a strong current toward the west end of the powerhouse. 


\subsection{Smolt Survival Studies}

Since 2000, radio telemetry has been used to estimate survival of juvenile salmonid outmigrants at The Dalles Dam. Survival of salmonid smolts through The Dalles Dam is typically lower than at other projects on the lower Columbia River (Ploskey et al. 2001a). In recent years various spill levels, spill configurations, and dam modifications have been implemented at The Dalles Dam to increase the survival of migrating smolts. Lower-than-expected spill passage survival probabilities at The Dalles Dam are thought to be due to 1) predation when spilled water carrying juvenile salmonids moves through areas inhabited by gulls (Larus spp.), northern pikeminnow (Ptychocheilus oregonensis), and smallmouth bass (Micropterus dolomieu), and 2) a short stilling basin and shallow tailrace, resulting in severe turbulence and lateral currents that may cause physical injury to migrant salmon. As mentioned above, to prevent lateral currents in the stilling basin, a spillwall was constructed during winter 2003/2004. Spill operations were changed to target $40 \%$ spill through Bays 1-6. The intent of these modifications was to increase the survival of juvenile salmonids that pass through the spillway.

The release-recapture models of Cormack (1964), Jolly (1965), and Seber (1965) have been adapted for use with radio-telemetry data to estimate smolt survival through hydroelectric projects (Burnham et al. 1987; Skalski et al. 2002). The route-specific survival model (Skalski et al. 2002) was used in 2002, 2004, and 2005 to estimate the survival probabilities of juvenile Chinook salmon through the spillway, the sluiceway, and turbines. The route-specific estimates of passage and survival probabilities were then combined to estimate dam survival. The paired release-recapture model (Burnham et al. 1987) was used to estimate survival of juvenile Chinook salmon through the sluiceway in 2001 and 2004, and for spill bay-specific survival studies in 2002, 2004, and 2005. In 2006, spill bay-specific survival was estimated using the single release-recapture model. Each model used to estimate survival has its own set of assumptions and possible biases; refer to Peven et al. (2005) for details. Conditions during the survival studies are presented in Table 7.1.

\subsection{Survival Estimates}

Survival estimates generated using the route-specific survival model for studies conducted at The Dalles Dam during 2002, 2004, and 2005 are presented in Table 7.2. The 2004 summer study period was approximately one week longer than other years to look at the effects of temperatures above $21^{\circ} \mathrm{C}$ on survival of radio-tagged fish. To make estimates for 2004 more comparable to other years, separate survival estimates were generated for releases made from June 20 to July 21, the more typical 32-day study length.

Trends in route-specific survival estimates for yearling and subyearling Chinook salmon were similar during 2002, 2004, and 2005. With the exception of subyearling sluiceway survival in 2004, survival was highest for fish passing via the ice and trash sluiceway, lower for the spillway, and lowest for fish passing via the turbines at the powerhouse (Table 7.2). The survival estimates from the three years of route-specific studies do not suggest that there was a large survival benefit associated with the installation of the spillwall in the spillway stilling basin. The point estimates of spillway survival for 2005 were higher than 2002 (pre-construction) and 2004 (post-construction); however, the differences were small and there was significant overlap in $95 \%$ confidence intervals. 
Table 7.1. Summary of Study Timing, Fish Size Statistics, and Tag Specifications for Radio Telemetry Survival Studies at The Dalles Dam, 2001-2005. There were no survival studies done in 2003. NA indicates that the information was not available. All fish (treatment and control) released that season were combined for fish size statistics.

\begin{tabular}{lllll}
\hline & 2001 & 2002 & 2004 & 2005 \\
\hline \multicolumn{4}{c}{ A) Yearling Chinook Salmon } \\
\hline Study start date & 8-May & 30-Apr & 27-Apr & 29-Apr \\
Study end date & 4-Jun & 1-Jun & 29-May & 31-May \\
Min fork length (mm) & 135 & 114 & 122 & 126 \\
Max fork length (mm) & 229 & 221 & 230 & 220 \\
Mean fork length (mm) & 168 & 148 & 157 & 154 \\
Median fork length (mm) & 165 & 145 & 154 & 151 \\
Min weight (g) & 22.5 & 13.4 & 21.5 & 21.5 \\
Max weight (g) & 111.7 & 95.9 & 124.6 & 97.9 \\
Mean weight (g) & 45.9 & 30.9 & 38.4 & 36.3 \\
Median weight (g) & 42.0 & 28.2 & 35.1 & 33.4 \\
Tag weight (g) & 1.4 & 1.4 & 1.4 & 1.0 \\
Tag dimensions (mm) & 7.3 x 18.0 & $7.3 \times 18.0$ & $7.3 \times 18$ & $7.2 \times 17.0$ \\
Tagging method & gastric & gastric & gastric & gastric \\
\hline
\end{tabular}

B) Subyearling Chinook Salmon

\begin{tabular}{lllll}
\hline Study start date & 19-Jun & 21-Jun & 19-Jun & 15-Jun \\
Study end date & 12-Jul & 22-Jul & 29-Jul & 17-Jul \\
Min fork length (mm) & 110 & 107 & 100 & 92 \\
Max fork length (mm) & 162 & 157 & 181 & 153 \\
Mean fork length (mm) & 122 & 118 & 116 & 108 \\
Median fork length (mm) & NA & 115 & 113 & 106 \\
Min weight (g) & 14.0 & 12.4 & 13.0 & 10.0 \\
Max weight (g) & 48.0 & 42.4 & 68.3 & 40.5 \\
Mean weight (g) & 19.6 & 17.4 & 17.1 & 13.9 \\
Median weight (g) & NA & 15.9 & 15.6 & 13.0 \\
Tag weight (g) & 0.85 & 0.85 & 0.85 & 0.43 \\
Tag dimensions (mm) & $6.8 \times 15.0$ & $6.8 \times 15.0$ & $6.8 \times 15$ & $5.6 \times 13.9$ \\
Tagging method & gastric & gastric & gastric & gastric \\
\hline
\end{tabular}


Table 7.2. Survival Estimates for Yearling and Subyearling Chinook Salmon Passing The Dalles Dam in 2002, 2004, and 2005. 95\% confidence limits for project, pool, and dam estimates, and profile likelihood 95\% confidence limits for turbine, sluiceway, and spillway estimates are listed below survival. Estimates were generated using the routespecific survival model and radio-tagged fish released by boat in the tailraces of John Day Dam (treatment) and The Dalles Dam (control).

\section{A) Yearling Chinook salmon}

\begin{tabular}{cccccc}
\hline Project & Pool & Dam & Turbines & Sluiceway & Spillway \\
\hline \multicolumn{7}{c}{ April 30 - June 1 2002 (Counihan et al. 2006a) } \\
0.730 & 0.837 & 0.872 & 0.849 & 0.911 & 0.882 \\
$0.690,0.770$ & $0.816,0.857$ & $0.831,0.913$ & $0.802,0.894$ & $0.833,0.974$ & $0.845,0.920$ \\
\hline \multicolumn{7}{c}{ April 27 - May 29 2004 (Counihan et al. 2006b) } \\
0.866 & 0.956 & 0.906 & 0.797 & 0.981 & 0.909 \\
$0.843,0.889$ & $0.947,0.965$ & $0.891,0.921$ & $0.722,0.863$ & $0.943,1.010$ & $0.892,0.925$ \\
\hline 0.892 & April 29 - May 31 2005 (Counihan et al. 2006c) & \\
$0.864,0.920$ & $0.944,0.968$ & $0.918,0.949$ & $0.769,0.895$ & $0.984,1.015$ & $0.921,0.954$ \\
\hline
\end{tabular}

B) Subyearling Chinook salmon

\begin{tabular}{|c|c|c|c|c|c|}
\hline Project & Pool & Dam & Turbines & Sluiceway & Spillway \\
\hline \multicolumn{6}{|c|}{ June 21 - July 222002 (Counihan et al. 2006a) } \\
\hline 0.752 & 0.862 & 0.872 & 0.817 & 0.907 & 0.906 \\
\hline $0.724,0.780$ & $0.850,0.874$ & $0.843,0.901$ & $0.785,0.850$ & $0.854,0.955$ & $0.880,0.934$ \\
\hline \multicolumn{6}{|c|}{ June 19 - July 212004 (Counihan et al. 2006b) } \\
\hline 0.799 & 0.911 & 0.878 & 0.729 & 0.735 & 0.916 \\
\hline $0.769,0.830$ & $0.895,0.927$ & $0.857,0.899$ & $0.655,0.798$ & $0.622,0.834$ & $0.895,0.936$ \\
\hline \multicolumn{6}{|c|}{ June 19 - July 292004 (Counihan et al. 2006b) } \\
\hline 0.694 & 0.850 & 0.817 & 0.674 & 0.668 & 0.860 \\
\hline $0.667,0.720$ & $0.834,0.865$ & $0.796,0.838$ & $0.613,0.733$ & $0.577,0.753$ & $0.838,0.881$ \\
\hline \multicolumn{6}{|c|}{ June 15 - July 172005 (Counihan et al. 2006c) } \\
\hline 0.852 & 0.947 & 0.900 & 0.796 & 0.931 & 0.925 \\
\hline $0.824,0.880$ & $0.935,0.959$ & $0.881,0.918$ & $0.742,0.845$ & $0.845,0.988$ & $0.907,0.942$ \\
\hline
\end{tabular}


Paired-release-recapture model survival estimates for juvenile Chinook salmon passing the sluiceway in 2001 and 2004 are presented in Table 7.3. In 2004, for each release of fish into the sluiceway, two survival estimates were calculated. One estimate paired treatment fish with a control release immediately below the sluiceway (sluiceway tailrace control) and a second paired treatment fish with a control release made 1,800 ft downstream of the spillway under the Highway 197 bridge (dam tailrace control). The relative survival through the sluiceway was lower when estimated using control fish released 1,800 ft downstream of the spillway tailrace that when compared to fish released immediately below the sluiceway.

Table 7.3. Survival Estimates for Yearling and Subyearling Chinook Salmon Passing The Dalles Dam Sluiceway, 2001 and 2004. Confidence limits (95\%) are listed below survival estimates. Estimates were generated using the paired release-recapture model and radiotagged fish released via a pipe into the top of the sluiceway (treatment) and by boat in the tailrace (control).

\begin{tabular}{|c|c|c|c|}
\hline Treatment release site & Control release site & $\begin{array}{c}\text { Yearling Chinook } \\
\text { survival }\end{array}$ & $\begin{array}{c}\text { Subyearling Chinook } \\
\text { survival }\end{array}$ \\
\hline \multicolumn{4}{|c|}{2001 (Counihan et al. 2002) } \\
\hline Top of sluiceway & $\begin{array}{c}\text { Dam tailrace, } \\
\sim 500 \mathrm{~m} \text { downstream } \\
\text { of spillway }\end{array}$ & $\begin{array}{c}0.993 \\
0.945-1.041\end{array}$ & $\begin{array}{c}0.962 \\
0.906-1.018\end{array}$ \\
\hline \multicolumn{4}{|c|}{2004 (Counihan et al. 2006b) } \\
\hline Top of sluiceway & $\begin{array}{l}\text { Sluiceway tailrace, } \\
\sim 25 \mathrm{~m} \text { downstream } \\
\text { of outfall }\end{array}$ & $\begin{array}{c}0.987 \\
0.956-1.018\end{array}$ & $\begin{array}{c}1.060 \\
0.893-1.228\end{array}$ \\
\hline Top of sluiceway & $\begin{array}{l}\text { Dam tailrace, } \\
\sim 500 \mathrm{~m} \text { downstream } \\
\text { of spillway }\end{array}$ & $\begin{array}{c}0.957 \\
0.924-0.991\end{array}$ & $\begin{array}{c}0.804 \\
0.741-0.866\end{array}$ \\
\hline
\end{tabular}

Recent research suggests that survival at The Dalles Dam spillway is lower for juvenile Chinook salmon passing more southern spill bays compared to those passing more northern spill bays (Section 4). Fish passage at The Dalles Dam spillway is influenced by spill patterns (Section 4.4). Spill patterns were changed from 2002 to 2005 , so that each year spillway discharge was sent through fewer and more northern bays (Hausmann et al. 2004; Hansel et al. 2005; Hansel et al. 2007). Concurrently, juvenile Chinook salmon passage was different each year so that fish were passing more northern bays (Hausmann et al. 2004, Hansel et al. 2005, Hansel et al. 2007) where survival probabilities were higher (Normandeau Associates Inc. 2003, Counihan et al. 2006a,b,c). The small increases in survival from 2002 to 2005 may be a result of the differences in fish passage. However, interpretation of the survival results at The Dalles Dam spillway is confounded by differences in environmental conditions during the one-year of pre-construction and the subsequent two years of post-construction survival evaluations (Section 4). Similar trends toward increasing survival are evident for fish passing the sluiceway for yearling Chinook salmon. After a marked decrease in survival during 2004, the point estimate of the survival of subyearling Chinook salmon passing the ice and trash sluiceway during 2005 was higher than that observed during 2002 and 2004. This suggests that other factors or environmental conditions may have affected survival. 
Overall dam survival increased slightly from 2002 to 2005 (Table 7.2). However, because of the variability in dam operations and environmental conditions across years, comparisons of survival across years are confounded. For example, in addition to differences in spillway operations, powerhouse turbine and sluiceway operations in 2002 differed from 2004 and 2005. In 2002, turbine passage with and without a series of J-occlusion plates designed to block the upper portion of the turbine intakes were tested at several turbines. Operating turbines at The Dalles Dam are typically alternated along the powerhouse, but in 2002 Main Units 1 through 5 were block loaded to provide consistent conditions for the J-occlusion tests (Hausmann et al. 2004). Research results suggest that these operations resulted in greater turbine entrainment of juvenile salmonids (Hausmann et al. 2004; Johnson et al. 2003).

\subsection{Summary}

To summarize the survival estimates, we averaged data from radio telemetry studies in 2002 , 2004, and 2005 (Table 7.4).

Table 7.4. Mean Survival Estimates from Radio Telemetry Studies in 2002, 2004, and 2005. Data from 2004 do not include July 22-29 when water temperatures exceeded 21 deg C. Estimates were generated using the route-specific survival model and radio-tagged fish released by boat in the tailraces of John Day Dam (treatment) and The Dalles Dam (control).

\begin{tabular}{ccccccc}
\hline & Project & Pool & Dam & Turbines & Sluiceway & Spillway \\
\hline CH 1 & 0.829 & 0.916 & 0.904 & 0.828 & 0.966 & 0.910 \\
CH 0 & 0.801 & 0.907 & 0.883 & 0.781 & 0.858 & 0.916 \\
\hline
\end{tabular}

- Route-specific survival for yearling Chinook salmon is highest at the sluiceway (97\%) and lowest at the turbines $(83 \%)$.

- Route-specific survival for subyearling Chinook salmon is highest at the spillway (92\%) and lowest at the turbines (78\%).

- Dam and pool survivals are both about $90 \%$, producing a project survival of about $81 \%$. 


\subsection{Discussion}

In this section, we discuss the current understanding of juvenile salmonid passage at The Dalles Dam, improvements to passage conditions, and critical uncertainties. The section closes with conclusions about the state of the knowledge base regarding juvenile salmonid passage at The Dalles Dam.

\subsection{Current Understanding}

Juvenile salmonid passage at The Dalles Dam is characterized by short residence times (fractions of an hour), high sluiceway effectiveness ( $>3: 1)$, fish passage efficiency $80-90 \%$, dam survival for smolts about $90 \%$, and project survival (pool and dam combined) about $80 \%$. Fish approach paths of juvenile steelhead and yearling and subyearling Chinook salmon are known, and appear to be largely determined by the time fish reach the forebay at the upstream end of the powerhouse. There are two common paths after fish pass Big Eddy: one directly toward the spillway and another toward the powerhouse. The path fish are on does not appear to affect turbine passage during the day, but at night a much greater proportion of the fish traveling toward the powerhouse pass via the turbines than those headed directly to the spillway. The migration through the forebay generally takes less than $0.6 \mathrm{~h}$ (median).

Much is known about juvenile fish passage at The Dalles Dam spillway, yet it continues to be a route with lower passage survival than at other spillways in the FCRPS. This is likely due to the unique and complex tailrace environment at this site. Deep canyons, shallow sills, and islands in the tailrace produce habitat favorable to piscivorous fish and the shallow stilling basin likely contributes to fish injuries and disorientation, making juvenile salmonids more vulnerable to predation by both fish and birds. The goal of recent changes in operations and structures at the spillway has been to increase spillway passage survival by eliminating lateral flows in the stilling basin and passing fish to the deep thalweg downstream from the northern end of the spillway. Compressing the juvenile spill pattern to the northernmost spill bays achieved this outcome, but presented new problems. These included poor survival of fish passing southern bays due to a lateral movement of water and fish within the stilling basin. A spill pattern typically constrained to the northernmost six spill bays along with a spillwall installed between Bays 6 and 7 addressed the lateral movement of these fish, but result in little change in overall spillway survival.

Overall dam passage survival at The Dalles Dam remains a concern, especially for subyearling Chinook salmon. The dam survival estimates of yearling and subyearling Chinook salmon in 2002, 2004, and 2005 ranged from 0.82 to 0.93 . The sluiceway generally has the highest estimates of survival (range 0.67 to 1 ), followed by the spillway (range 0.88 to 0.94 ) and turbines (range 0.67 to 0.85 ). Route-specific survival of yearling Chinook salmon is slightly higher than that of subyearling Chinook salmon through the sluiceway, but survivals of the two groups are similar to one another through the turbines and spillway. Estimates of subyearling Chinook salmon survivals in 2004 were considerably lower when based on June 19 to July 29 analyses than when based on June 19 to July 21 analyses, indicating lower survival during the later part of July than earlier in the study.

Survival through the sluiceway has varied from near 0.735 to 1 and is generally lower for subyearling Chinook salmon than for yearling Chinook salmon. The mortality of sluiceway-passing subyearling Chinook salmon was highest in 2004 and appeared to be incurred mostly between the outfall site and the route 197 bridge. Tests in 2004 showed relative survival of yearling Chinook salmon was similar when control sites were near the outfall site (0.987) and under the Highway 197 bridge in the thalweg (0.957). However, survivals for subyearling Chinook salmon were much lower based on the bridge control site (0.804) than the outfall site location (1.060), indicating the mortality of these fish was associated with the 
in-river migration between the two sites, rather than from passage through the sluiceway. The cause(s) of the different results in the spring and summer in 2004 is unknown, but could include project operations and water temperature.

Increases in dam survival will be most likely if survivals through the spillway or turbines are improved or turbine entrainment is reduced. In most years spill will likely be a significant part of any method to increase dam passage survival, and thus improvements to the spillway or the location of fish passing within the spillway will have the greatest potential for success. Survival through the sluiceway is generally high, and the mortality associated with this route appears to be related to the predation after exiting the sluiceway rather than passage through the route itself. Increasing dam passage through improvements at the sluiceway will be critical to improve dam passage survival if spill levels are reduced. Increasing the proportion of fish passing this route would provide some increase in dam survival during most conditions and should be considered as a strategy for increasing dam passage survival during low flow years, when the availability of voluntary spill for fish passage is diminished.

\subsection{Passage Improvements}

\subsubsection{Forebay}

Altering fish approach paths to the powerhouse may have the potential to reduce turbine passage. Turbine passage is highest during the night, especially for fish in the migration pathway closest to the powerhouse (see Figures 3.3 and 3.4). A forebay guidance device was investigated in 2005, but its development was slowed after concerns were raised about passing even more fish through the spillway given its low passage survival. The greatest benefit from such a device would be realized at night, as this is when turbine passage of fish traveling near the powerhouse is greatest. Cash et al. (2005) used data from the acoustic-tagged fish to model the effectiveness of a guidance structure at the powerhouse. They suggested the highest spillway passage efficiencies of yearling Chinook salmon would be realized with a $900 \mathrm{ft}$-long diversion structure attached at MU 22 and placed at a 30-degree angle to the powerhouse. They also suggested a similar structure placed at MU 13 would maximize spillway passage efficiency of juvenile steelhead. The depths evaluated in the exercise by Cash et al. (2005) ranged from 13 to $26 \mathrm{ft}$, but showed little improvement in simulated performance for structures deeper than $16 \mathrm{ft}$.

\subsubsection{Spillway}

The underlying premise of optimizing spillway passage survival by passing fish into the thalweg downstream remains sound. The spillway is an efficient means of passing juvenile salmonids. The selection of where in the tailrace to pass them is based on data indicating piscivorous fish reside along shorelines and islands throughout the tailrace and their presence can be predicted based on distance from shore, water velocity, and water depth. Passing fish to the thalweg reduces predator habitat via each of these factors. However, getting fish to the thalweg before other sources of mortality apparently have an effect has been difficult.

Survival through the spillway has yet to be increased to the generally accepted level of $98 \%$. This is largely due to the inability to pass fish through the locations at the spillway with the greatest survival, but even those areas fail to fully meet the $98 \%$ expectation. For example, overall spillway survival of yearling Chinook salmon in 2004 was 0.938, survival through Bays 1-4 was 0.967; and survival through Bays 5 and 6 was 0.933. The estimates from subyearling Chinook salmon are 0.925, 0.972, and 0.887, respectively. As these data indicate, the survival of juvenile salmonids passing the spillway through Bays 
1-4 in the current bulked spill pattern configuration is known to be higher than for those passing via Bays 5 and 6. The differences are thought to be a result of injury from passage near the concrete spillwall and/or the egress paths of fish from Bays 5 and 6 . Thus, the problem of improving spillway passage is two-fold 1) how to pass fish predominantly through Bays 1-4, and 2) how to increase the survival of fish through these and other bays.

The inability to pass fish through the desired bays appears to be a result of the high spill effectiveness of bays near the southern edge of the spill pattern. This is likely a result of the paths of fish that travel through the forebay, reach the spillway south of the open bays, travel northward along the spillway, and pass through the first few spill bays they encounter. This behavior is likely greatest, but not exclusively, in fish migrating near the powerhouse. Changing this approach pattern may be the key to reducing the effectiveness of spill bays near the southern edge of the spill pattern. The addition of a behavioral guidance structure attached to the upstream end of the powerhouse could alter the paths of some of these fish, but additional measures may also be needed. An additional guidance device somewhere between the western edge of the powerhouse and spillway may divert additional fish away from this approach path, resulting in improvements in overall spillway survival by altering their spillway passage location.

Existing data suggest that changing spillway passage location by reducing spill in southern-edge bays will be ineffective. Spill effectiveness is inversely related to spill discharge, and using small amounts of spill in edge bays will likely result in many fish passing those bays. Data from fish passage through Bay 7 in 2004 support this premise (Figures 4.2 and 4.3).

Surface spill methods, such as the removable spillway weirs used at some Snake River dams, have been shown to pass fish from areas well upstream and could possibly have a similar effect at The Dalles Dam. Surface spill at TDA could be used to concentrate fish in the Bay 1-4 area. However, such a device may have little effect on spill passage through southern-edge bays. One alternative currently being considered, a pair of bulkheads to act as vortex suppression devices in Bays 5 and 6, may reduce the spill effectiveness of these bays; however, this alternative has yet to be tested.

Other spillway improvement ideas involve changing bathymetry and the spillwall. Based on work with predators, there are three constraints on predator habitats: distance from shore, water velocity, and water depth. Distance from shore is fixed and water velocity is already high. Perhaps the tailrace islands could be excavated to a depth of 40-50 ft. This might eliminate predator habitat, channel spill discharge, and reduce that portion of water and fish that spreads south and into the shallow and island areas. Extending and redirecting the spillwall might also have the same effect, but care will have to be taken to not create predator habitat along the downstream end of the spillwall.

\subsubsection{Sluiceway}

Passage survival at the sluiceway seems to be high enough $(>0.96)$ in most years to warrant enhancements of the sluiceway as a non-turbine route at The Dalles Dam. The greatest benefits of enhancements would be realized during low- or no-spill operations, although sluiceway enhancement should be part of a strategy to provide non-turbine passage routes over a wide range of operations. Toward this alternative, the USACE has drafted a Configuration and Operations Plan for The Dalles Dam (USACE 2007). This plan includes modeling of various operational scenarios and hypothesized effects on survival rates that will help determine if enhanced sluiceway passage is likely to result in an appreciable $(>2 \%)$ increase in total project survival. 
A key aspect to the sluiceway's potential is that it pass fish otherwise destined for turbines and not fish otherwise destined for the spillway. This is certainly possible because of the sluiceway's location at the powerhouse where $60 \%$ or more of total project discharge occurs during the spring and summer juvenile fish passage seasons. However, an enhanced sluiceway may also divert fish that otherwise would pass in spill, especially with a $40 \%$ spill level. Indeed, sluiceway enhancements may be most applicable in conjunction with reduced spill levels, 30\% for example. Further integrative passage and survival modeling efforts by the USACE for the Configuration and Operations Plan will be revealing about the benefits of sluiceway enhancements at TDA. Given that sluiceway passage survival is higher than spillway passage survival and that the sluiceway can pass high percentages of fish when spill is low or curtailed suggests that this route should receive as much consideration as the spillway. Furthermore, without a forebay guidance device or other mechanism to divert fish to the spillway, the sluiceway remains the only non-turbine passage route at the powerhouse and should be prioritized for enhancements accordingly.

How can the sluiceway entrances be modified or operated or both to reduce turbine entrainment? It is clear from the fish behavior data in the sluiceway nearfield that fish will move up in the water column to pass into the sluiceway. It is also evident that turbine passage at units beneath open sluice gates is lower than when the gates are closed. What is uncertain is whether the sluiceway entrances can be modified or operated to reduce turbine entrainment even more. An engineering design effort to identify alternatives for sluiceway enhancements to reduce turbine entrainment should be considered.

Sluiceway discharge is fundamental to the efficacy of sluiceway enhancements at The Dalles Dam. As a design parameter, sluiceway discharge is consistent with the considerations for surface flow outlets identified by Johnson and Dauble (2006): 1) form an extensive surface flow bypass flow net (surface bypass discharge greater than $\sim 7 \%$ of total project discharge) at the west and east ends of the dam; 2 ) create a gradual increase in water velocity approaching the surface flow bypass (ideally, acceleration $<1$ $\mathrm{m} / \mathrm{s} / \mathrm{m}) ; 3$ ) make water velocities at an entrance high enough $(>3 \mathrm{~m} / \mathrm{s})$ to entrain the subject juvenile fishes; 4) adapt the shape and orientation of the surface entrance(s) to fit site-specific features; and 5) design a new high flow outfall(s). These elements should be considered during design of sluiceway enhancements at The Dalles Dam.

Specifically, we suggest a portable weir with specially designed shaping be constructed and evaluated at the TDA sluiceway. This structure, called the "Portable Sluiceway Weir," would allow comparison of fish response to hydraulic conditions created by entrance shaping with those at an existing, non-shaped sluice entrance at TDA. A portable structure would allow researchers to prevent any location effects from confounding the evaluation. Since many fish approach the sluiceway entrances but move away from the outlets toward the west (Johnson et al. 2004), this structure could also be used to develop immediate improvements to sluiceway efficiency, even at its existing hydraulic capacity.

In general, sluiceway enhancement could be a reliable, long-term strategy for juvenile salmonid passage at The Dalles Dam. Because of the variability among years in spill efficiency (Ploskey et al. 2001a), spillway improvements alone may not be sufficient to protect juvenile salmonids across the entire dam during every annual emigration. Surface flow outlets are being designed, installed, and operated as long-term juvenile salmonid passage routes at a growing number of mainstem dams (Sweeney et al. 2007). Examples include the "Removable Spillway Weirs" at Lower Granite and Ice Harbor dams and the "Corner Collectors" at Bonneville and Rocky Reach dams. Therefore, a diverse, multi-faceted approach that includes sluiceway enhancements as a surface flow outlet at the powerhouse is in order. Data have repeatedly shown that The Dalles Dam sluiceway has the potential to be highly efficient and 
effective at passing juvenile salmonids, especially when assessed relative to powerhouse passage. This potential could be tapped with hydraulic and entrance enhancements to the sluiceway.

\subsection{Critical Uncertainties}

What are optimum spill proportions and rates? A strong relationship between spill passage efficiency and spill proportion or spill volume is not evident at this time. Further analysis of fish/spill relationships would inform discussions concerning less than $40 \%$ spill at The Dalles Dam. A relationship between percentage spill and sluiceway efficiency also is of interest, because it could help identify spill levels that maximize both FPE and survival. A purposeful evaluation that involves a blocked experimental design of spill treatments equating to $40 \%$ in aggregate should be considered.

What are the mechanisms of mortality downstream of the spillway? A related question is: What is the maximum spill gate opening for safe fish passage? These questions have received much attention but they remain critical uncertainties. Research is needed to differentiate and rank causes of mortality related directly or indirectly to baffle blocks, predation, etc., and to relate the results to amount of gate opening. In addition to obligatory field studies on this topic, laboratory experiments should be considered.

What is the behavioral response of juvenile salmonids to a guidance wall in The Dalles Dam forebay? Nothing is known about the behavior of juvenile salmonids encountering artificial walls in The Dalles dam forebay. Such knowledge would support decision-making and design of a forebay guidance wall. Fish movements during encounter with a preliminary prototype wall should be tracked in three dimensions and studied. Depending on where the prototype wall is deployed, fish passage at the turbine units behind it could also be estimated. An experimental design using a small wall $(\sim 250 \mathrm{ft})$ with wall in and wall out treatments would be appropriate, as would a study comparing fish behavior between walls located in eastern and western positions in the forebay.

What about sockeye and coho salmon and subyearling migrants in late summer and fall? We have no data for sockeye or coho salmon passage and survival at The Dalles Dam, except for some sockeye from Cash et al. (2005) and the coho survival data by Dawley et al. (2000). While coho salmon abundance is generally low, sockeye migration sizes vary with some years having significant numbers, e.g., 2002. Late subyearling Chinook salmon migrants likely contribute to life history diversity and resiliency in the species. Passage survival of these fishes is a concern at upstream dams and could be on the horizon for concern at The Dalles Dam. Future research should consider these salmonid species and life history patterns.

What impacts do operational or structural improvements made to enhance salmonid survival have on populations of non-salmonid fishes? One such species is the white sturgeon (Acipenser transmontanus), an amphidromous species living throughout the FCRPS, but thriving only downstream from Bonneville Dam. The development of hydropower in the Columbia River basin has created a series of discrete metapopulations of white sturgeon separated by dams. Jager (2006) suggests that upstream and downstream migrations are important for the viability of white sturgeon in impounded systems. Little upstream movement has been noted at most dams in the FCRPS, though downstream movement has been documented at several (Warren and Beckman 1993). White sturgeon are known to spawn in the tailrace of TDA during certain conditions, and they use the adult ladder system at TDA more than at any other dam studied in the FCRPS. Parsley et al. (in press) found that these fish move upstream and downstream at TDA, primarily through the east ladder and spillway, and some individuals do so repeatedly. Another species of concern, the Pacific lamprey (Lampetra tridentata), is an anadromous fish that has been considered (and rejected) for inclusion under the Endangered Species Act. This species is known to have 
difficulty ascending adult ladders designed for salmonids, but Moser et al. (2002) found higher upstream passage success at The Dalles Dam than at Bonneville or John Day dams. Overall, only about 3\% of radio-tagged lamprey released downstream from Bonneville Dam reached the John Day Dam forebay. Given the relative success of passage at TDA, changes in project operations could affect their access to, or success in passing, the adult ladders at TDA, impeding their upstream migration. Thus, the effects of changes in spill patterns, proportions, or other operations should be considered in terms of their potential effects on these and possibly other non-salmonid species or life stages.

What can be done to increase the survival rates for subyearling Chinook salmon? Subyearlings are smaller and more vulnerable to turbine entrainment, injury, and predation than their yearling counterparts. Subyearling fish migrate deeper in the water column than yearling and, therefore, may benefit less from surface flow outlet technology than yearlings. Design of project operations and structural improvements to benefit subyearlings is the biggest critical uncertainty for juvenile fish passage at The Dalles Dam.

\subsection{Conclusions}

This synthesis reveals strengths and weaknesses in the state of the knowledge concerning juvenile salmonid passage at The Dalles Dam. The USACE and agency personnel are using this knowledge base to make decisions regarding measures to increase smolt survival at The Dalles Dam.

In the forebay, data on approach paths, distributions, and residence times are solid, but we know little about the behavioral response by juvenile salmonids to an artificial guidance wall in the TDA forebay specifically. A forebay wall could figure prominently in a measure to reduce turbine passage at the powerhouse.

At the turbines, the knowledge base is strong regarding the poor performance of intake occlusion at TDA and higher fish densities $(\# / \mathrm{h} / \mathrm{kcfs})$ at eastern units in summer than spring. Multiple studies failed to demonstrate a consistent positive effect, i.e., reduced turbine passage rates, from occluding the upper portion of the turbine intake trash racks; some studies even showed a negative effect. We also have reliable knowledge from fish behavior studies, and hydraulic measurements and modeling, that juvenile salmonids at the face of the trash racks are not necessarily entrained because fish are capable of swimming against the relatively low water velocities $(\sim 2 \mathrm{fps})$. On the other hand, knowledge from applying this and the forebay approach data to identify measures for reducing turbine passage is lacking. Such a forebay/turbine integrative effort might involve a berm placed at the downstream end of Big Eddy to drive the vertical distribution of fish toward the surface making them less vulnerable to turbine passage.

The importance of the sluiceway as a non-turbine passage route, especially during no spill, is wellaccepted and fish behavior in the nearfield $(<30 \mathrm{ft})$ is well-understood. The knowledge base is strong on sluiceway efficiency, effectiveness, survival, and springtime sluiceway operational configurations. For summer migrants, however, the knowledge base for sluiceway operations is relatively weak. For example, we do not know sluiceway efficiency for subyearling fish during an operation with sluice inflow concentrated at entrances on the eastern end of the powerhouse. We also do not know if sluiceway efficiency could be increased without decreasing spill efficiency by simply reshaping the sluice entrances to eliminate the abrupt increase in acceleration at the sluice sill.

At the spillway, we have a good understanding of spill efficiency, effectiveness, survival rates, and egress paths and rates. A clear relationship is not apparent between spill efficiency and spill proportion or 
spill rate, in part because the typical operation calls for a constant spill proportion. The relative impact of various mechanisms of mortality downstream of the spillway ogee remains to be elucidated.

In closing, for the project as a whole, we understand well many aspects of juvenile fish passage, including forebay approach and tailrace egress migration routes and travel rates; project and routespecific survival rates; fish passage efficiencies; vertical, horizontal, and diel distributions; and hydraulic conditions and current patterns in the forebay and tailrace. We are less certain about relationships between juvenile salmonid responses and hydrodynamic conditions, spill efficiency and spill operations, mechanisms of mortality and mortality rates downstream of the spillway ogee. Increased understanding of these relations, especially those for subyearling Chinook salmon, will provide a basis for measures to increase juvenile salmonid survival in a cost-effective manner at The Dalles Dam. 


\subsection{References}

Absolon, R. F., D. A. Brege, B. P. Sandford, D. B. Dey. 1995. Studies to evaluate the effectiveness of extended-length screens at The Dalles Dam, 1994. Report to the U.S. Army Corps of Engineers, Contract E96930030, by the National Marine Fisheries Service, Seattle, WA.

Allen, M. B., B. J. Hausmann, J. L. Schei, T. L. Liedtke, L. S. Brow, A. J. Daniel, and J. Beeman. In prep. An evaluation of tailrace egress of Chinook salmon that pass via the sluiceway under each spill scenario tested at The Dalles Dam, 2001. Annual Report of Research to the U. S. Army Corps of Engineers, Portland District, Portland, Oregon, USA.

Beeman, J. W., S. D. Juhnke, K. Daniel, A. J. Daniel, and P. V. Haner. 2003. Estimates of the stilling basin residence time and lateral distribution of passage of juvenile Chinook salmon passing through the spillway at The Dalles Dam, 2001. Final report of research submitted to the U.S. Army Corps of Engineers - Portland, OR.

Beeman, J. W., H. C. Hansel, P. V. Haner, and K. Daniel. 2005. Estimates of Fish, Spill, and Sluiceway Passage Efficiencies of Radio-Tagged Juvenile Steelhead and Yearling Chinook Salmon at The Dalles Dam, 2001. Final report of research submitted to the U.S. Army Corps of Engineers - Portland District, October 10, 2002, by the USGS Biological Resources Division.

Beeman, J. W., S. D. Juhnke, H. C. Hansel, A. J. Daniel, L. L. Dingmon, P. V. Haner, and T. L. Liedtke. 2006. Estimates of the stilling basin residence time and lateral distribution of juvenile Chinook salmon passing through the spillway at The Dalles Dam during 2002. Final report of research submitted to the U.S. Army Corps of Engineers - Portland, OR.

Bevelhimer, M. S. 1996. Relative importance of temperature, food, and physical structure to habitat choice by smallmouth bass in laboratory experiments. Transactions of the American Fisheries Society 125:274283.

BioSonics, Inc. 1997. Hydroacoustic evaluation and studies at The Dalles Dam, spring/summer 1996. Volume 1 - Fish passage. Draft final report prepared by BioSonics, Inc. submitted to U. S. Army Corps of Engineers, Portland District.

Brege, D. A., R. F. Absolon, B. P. Sandford, D. B. Dey. 1994. Studies to evaluate the effectiveness of extended-length screens at The Dalles Dam, 1993. Report to the U.S. Army Corps of Engineers, Contract E96930030, $72 \mathrm{p}$.

Burnham, K. P., D. R. Anderson, G. C. White, C. Brownie, and K. H. Pollock. 1987. Design and analysis methods for fish survival estimates based on release-recapture. American Fisheries Society Monograph No. 5.

Cash, K. and 13 co-authors. 2005. Three-Dimensional Behavior and Passage of Juvenile Salmonids at The Dalles Dam, 2004. Draft final report submitted to the U.S. Army Corps of Engineers, Portland District, February 2005, by the USGS Biological Resources Division and PNNL.

Cook, C. B., M. C. Richmond, and J. A. Serkowski. 2006. The Dalles Dam, Columbia River: Spillway Improvement CFD Study. Final report submitted to the Corps of Engineers, Portland District by Pacific Northwest National Laboratory, Richland, Washington. PNNL-14768.

Cormack, R. M. 1964. Estimates of survival from the sighting of marked animals. Biometrika. 51: 429-438. 
Counihan T. D., G. S. Holmberg, K. J. Felton, and J. H. Petersen. 2002. Survival Estimates of Migrant Juvenile Salmonids through The Dalles Dam Ice and Trash sluiceway using Radio-Telemetry, 2001. Annual Report of Research prepared for the U.S. Army Corps of Engineers, Portland, OR.

Counihan, T. D., G. S. Holmberg, C. E. Walker, and J. M. Hardiman. 2006a. Survival estimates of migrant juvenile salmonids through The Dalles Dam using radiotelemetry, 2002. Final Report of Research prepared for the U.S. Army Corps of Engineers, Portland, OR.

Counihan, T. D., A. L. Puls, C. E. Walker, J. M. Hardiman, and G. S. Holmberg. 2006b. Survival estimates of migrant juvenile salmonids through The Dalles Dam using radiotelemetry, 2004. Final Report of Research prepared for the U.S. Army Corps of Engineers, Portland, OR.

Counihan, T. D., A. L. Puls, C. E. Walker, J. M. Hardiman, and G. S. Holmberg. 2006c. Survival estimates of migrant juvenile salmonids through The Dalles Dam using radiotelemetry, 2005. Final Report of Research prepared for the U.S. Army Corps of Engineers, Portland, OR.

Daniel, A. J., T. L. Liedtke, I. N. Duran, and J. A. Quenette. In review. Tailrace Egress and Travel Routes of Juvenile Chinook Salmon in The Dalles Dam Tailrace, 2005. Annual Report of Research to the U. S. Army Corps of Engineers, Portland District, Portland, Oregon, USA.

Dawley, E. M., L. G. Gilbreath, R. F. Absolon, B. P. Sandford, and J. W. Ferguson. 2000. Relative Survival of Juvenile Salmon Passing through the Spillway and the Ice and Trash Sluiceway of The Dalles Dam, 1998. Final report submitted to the U.S. Army Corps of Engineers, Portland District, by the National Marine Fisheries Service, Seattle, WA.

Duran, I. N., T. L. Liedtke, and J. H. Petersen. 2003. Predator-Prey Interactions in The Dalles Dam Tailrace, 2002. Annual Report of Research to the U. S. Army Corps of Engineers, Portland District, Portland, Oregon, USA.

Duran, I. N., J.A Quenette, T. L. Liedtke. 2006. Tailrace Egress of yearling and subyearling Chinook salmon following passage at The Dalles Dam, 2004. Appendix 9. in Counihan et al. 2006b. Survival estimates of migrant juvenile salmonids through The Dalles Dam using radiotelemetry, 2004. Final Report of Research to the U. S. Army Corps of Engineers, Portland District, Portland, Oregon, USA.

ENSR. 2001. Three-Dimensional Computational Fluid Dynamics (CFD) Modeling of the Forebay of The Dalles Dam, Oregon. Final Report by ENSR International submitted to U.S. Army Corps of Engineers, Portland, Oregon. Document Number 3697-006-320.

Faber, D. M,. M. E. Hanks, S. A. Zimmerman, J. R. Skalski, and P. W. Dillingham. 2005. The Distribution and Flux of Fish in the Forebay of The Dalles Dam in 2003 and Implications for Surface Flow Bypass. PNNL-14628, Final report submitted to the U.S. Army Corps of Engineers, Portland District, by Pacific Northwest National Laboratory, Richland, Washington.

Faler, M. P., L. M. Miller, and K. I. Welke. 1988. Effects of variation in flow on distributions of northern squawfish in the Columbia River below McNary Dam. North American Journal of Fisheries Management 8:30-35.

Guensch, G. R., M. C. Richmond, M. A. Weiland, and T. J. Carlson. 2004. Prototype Measurements of Pressure Fluctuations in The Dalles Dam Stilling Basin. PNNL-14585. Final report submitted to the Corps of Engineers, Portland District by Pacific Northwest National Laboratory, Richland, Washington. 
Hansel, H. C., and six co-authors. 2000. Estimates of Fish-, Spill-, and Sluiceway Passage Efficiencies of Radio-Tagged Juvenile Steelhead and Yearling Chinook Salmon at The Dalles Dam, 1999. Annual report of research, 1999, submitted to the U.S. Army Corps of Engineers, Portland District, by the USGS Biological Resources Division.

Hansel, H. C., J. W. Beeman, B. J. Hausmann, S. D. Juhnke, P. V. Haner, and J. L. Phelps. 2004. Estimates of fish-, spill-, and sluiceway passage efficiencies of radio-tagged juvenile Chinook salmon at The Dalles Dam in 2003. Draft Final Report of Research to the U.S. Army Corps of Engineers, Portland District, Portland, Oregon, USA.

Hansel, H. C., S. D. Juhnke, P. V. Haner, L. L. Dingmon, and J. W. Beeman. 2005. Estimates of fish-, spill-, and sluiceway passage efficiencies of radio-tagged juvenile Chinook salmon during spring and summer at The Dalles Dam in 2004. Annual Report of Research to the U.S. Army Corps of Engineers, Portland District, Portland, Oregon, USA.

Hansel, H. C., S. D. Juhnke, P. V. Haner, L.L. Dingmon, and J. W. Beeman. 2007. Estimates of fish-, spill-, and sluiceway-passage efficiencies of radio-tagged juvenile Chinook salmon during spring and summer at The Dalles Dam in 2005. Draft final report of research. Prepared by the U. S. Geological Survey for the U. S. Corps of Engineers, Portland, Oregon, USA.

Hausmann, B. J., J. W. Beeman, H. C. Hansel, S. D. Juhnke, and P. V. Haner. 2004. Estimates of Fish, Spill, and Sluiceway Passage Efficiencies of Radio-Tagged Juvenile Salmonids Relative to Operation of the Sluiceway Guidance Improvement Device at The Dalles Dam in 2002. Final report of research prepared for the U.S. Army Corps of Engineers, Portland District, by the USGS Biological Resources Division.

Hedgepeth, J. B., G. E. Johnson, A. E. Giorgi, and J. R. Skalski. 2002a. Sonar Tracker Evaluation of Fish Movements Relative to J-Occlusions at The Dalles Dam in 2001. Final report submitted to U.S. Army Corps of Engineers, Portland District, March 8, 2002, by Battelle Pacific Northwest Division, Richland, Washington.

Hedgepeth, J., G. Johnson, J. Skalski, and J. Burczynski. 2002b. Active fish tracking sonar (AFTS) for assessing fish behavior. Acta Acustica 88:739-742.

Helfman, G. S. 1986. Twilight activities and temporal structure in a freshwater fish community. Canadian Journal of Fisheries and Aquatic Sciences 38:1405-1402.

Hensleigh, J. E. and nine co-authors. 1999. Movement, Distribution, and Behavior of Radio-Tagged Juvenile Chinook Salmon and Steelhead in John Day, The Dalles and Bonneville Dam Forebays, 1997. Annual Report of Research, 1997, submitted to the U.S. Army Corps of Engineer, Portland District, by the U.S. Geological Survey.

Hoff, M. H. 1991. Effects of increased nesting cover on nesting and reproduction of smallmouth bass in northern Wisconsin lakes. Pages 39-43 in D. C. Jackson, editor. The first international smallmouth bass symposium. Mississippi State University, Mississippi.

Holmberg, G. S. and eight co-authors. 1997. Movement, Distribution, and Behavior of Radio-Tagged Juvenile Chinook Salmon in John Day, The Dalles, and Bonneville Dam Forebays, 1996. Annual Report of Research, 1996, submitted to the U.S. Army Corps of Engineers, Portland District, by the U.S. Geological Survey. 
Hosmer, D. W. Jr. and S. Lemeshow. 1999. Applied survival analysis: Regression modeling of time to event data. John Wiley and Sons, New York.

Jager, H. I. 2006. Chutes and ladders and other games we play with rivers. I. Simulated effects of upstream passage on white sturgeon. Canadian Journal of Fisheries and Aquatic Sciences: 63:165-175.

Johnson, G. E. 2000. Assessment of the acoustic screen model to estimate smolt passage rates at dams: case study at The Dalles Dam in 1999. Final report by BioAnalysts, Inc. submitted to Waterways Experiment Station.

Johnson, G. and D. Dauble. 2006. Surface Flow Outlets to Protect Juvenile Salmonids Passing Through Hydropower Dams. Reviews in Fisheries Science 14:213-244.

Johnson, G. E., J. B . Hedgepeth, A. E. Giorgi, and J. R. Skalski. 2001. Evaluation of Smolt Movements Using an Active Fish Tracking Sonar at the Sluiceway Surface Bypass, The Dalles Dam, 2000. Final report submitted to the U.S. Army Corps of Engineers - Portland District. September 30, 2001, by BioAnalysts, Inc.

Johnson, G. E., M. E. Hanks, J. B. Hedgepeth, B. D. McFadden, R. A. Moursund, R. P. Mueller, and J. R. Skalski. 2003. Hydroacoustic evaluation of turbine intake J-occlusions at The Dalles Dam in 2002. PNWD-3226. Prepared by Battelle Memorial Institute for the U.S. Army Corps of Engineers, Portland District, Portland, Oregon, USA.

Johnson, G. E., J. B. Hedgepeth, J. R. Skalski, and A. E. Giorgi. 2004. A Markov Chain Analysis of Fish Movement to Determine Entrainment Zones. Fisheries Research 69:349-358.

Johnson, G. E., M. E. Hanks, F. Khan, C. B. Cook, J. B. Hedgepeth, R. P. Mueller, C. L. Rakowski, M. C. Richmond, S. L. Sargeant, J. A. Serkowski, and J. R. Skalski. 2005. Hydroacoustic Evaluation of Juvenile Salmonid Passage at The Dalles Dam in 2004. PNNL-15180. Final report submitted to the Corps of Engineers, Portland District by Pacific Northwest National Laboratory, Richland, Washington.

Johnson, G. E., F. Khan, J. B. Hedgepeth, R. P. Mueller, C. L. Rakowski, M. C. Richmond, J. A. Serkowski, and J. R. Skalski. 2006. Hydroacoustic Evaluation of Juvenile Salmonid Passage at The Dalles Dam Sluiceway, 2005. PNNL-15540. Final report submitted to the Corps of Engineers, Portland District by Pacific Northwest National Laboratory, Richland, Washington.

Jolly, G.M. 1965. Explicit estimates from capture-recapture data with both death and immigration stochastic model. Biometrika. 52: 225-247.

Martinelli, T. L. and R. S. Shively. 1997. Seasonal distribution, movements and habitat associations of northern squawfish in two lower Columbia River reservoirs. Regulated Rivers: Research \& Management 13:543-556.

Mesa, M. G. and T. M. Olson. 1993. Prolonged swimming performance of northern squawfish. Transactions of the American Fisheries Society 122:1104-1110.

Michimoto, R. 1971. Bonneville and The Dalles Dams Ice-Trash Sluiceway Studies, 1971. Fisheries Engineering Research Program, Report \#20, submitted to the U.S. Army Corps of Engineers - Portland District, by the Oregon Department of Fish and Wildlife.

Moser, M. M., P. A. Ocker, L. C. Stuehrenberg, and T. C. Bjorn. 2002. Passage efficiency of adult pacific lampreys at hydropower dams on the lower Columbia River, USA. Transactions of the American Fisheries Society 131:956-965. 
Moursund, R. A., K. D. Ham, B. D. McFadden, and G. E. Johnson. 2001. Hydroacoustic evaluation of downstream fish passage at The Dalles Dam in 2000. PNWD-3226, Report to the U.S. Army Corps of Engineers, Portland District, by Battelle Pacific Northwest Division, Richland, Washington.

Moursund, R. A., K. D. Ham, P. S. Titzler, R. P. Mueller, G. E. Johnson, J. Hedgepeth, and J. R. Skalski. 2002. Hydroacoustic Evaluation of Fish Passage at The Dalles Dam in 2001. Report by Battelle's Pacific Northwest Division to the U.S. Army Corps of Engineers - Portland District.

Nagy, W. T. and M. K. Shutters. 1995. Hydroacoustic evaluation of surface collector prototypes at The Dalles Dam, 1995. Draft report by the USACE Fisheries Field Unit submitted to U. S. Army Corps of Engineers, Portland District.

Nestler, J. and R. Davidson. 1995. Imaging smolt behavior on an extended-length submerged bar screen and an extended-length submerged traveling screen at The Dalles Dam in 1993. Final report submitted to U. S. Army Corps of Engineers, Portland District. ERDC Technical Report EL-95-13.

Nichols, D. W. 1979. Passage Efficiency and Mortality Studies of Downstream Migrant Salmonids Using The Dalles Ice-Trash Sluiceway During 1978. Oregon Department of Fish and Wildlife.

Nichols, D. W. 1980. Development of Criteria for Operating the Trash Sluiceway at The Dalles Dam as a Bypass System for Juvenile Salmonids, 1979. Report submitted to the U.S. Army Corps of Engineers, Portland District, by the Oregon Department of Fish and Wildlife.

Nichols, D. W., and B. H. Ransom. 1981. Development of The Dalles Dam Trash Sluiceway as a DownStream Migrant Bypass System, 1980. Report submitted to the U.S. Army Corps of Engineers, Portland District, by the Oregon Department of Fish and Wildlife.

Nichols, D. W., and B. H. Ransom. 1982. Development of The Dalles Trash Sluiceway as a Downstream Migrant Bypass System, 1981. Annual Progress Report, submitted to the U.S. Army Corps of Engineers, Portland District, by the Fish Research Project Oregon, Fish Division, Oregon Department of Fish and Wildlife.

Normandeau Associates, Inc., J. R. Skalski, and Mid-Columbia Consulting, Inc. 1996. Potential effects of modified spillbay configurations on fish condition and survival at The Dalles Dam, Columbia River. Report to U.S. Army Corps of Engineers, Portland District, Portland, OR.

Normandeau Associates, Inc. and Mid-Columbia Consulting, Inc. 2001. Feasibility of estimating direct mortality and injury of juvenile salmonids passing The Dalles Dam spillway during high discharge. Report to U.S. Army Corps of Engineers, Portland District, Portland, OR.

Normandeau Associates, Inc., Mid-Columbia Consulting, Inc., and J. R. Skalski. 2003. Estimated direct mortality and injury of juvenile salmonids in passage through The Dalles Dam spillway, Columbia River in spring and summer 2002. Report to U.S. Army Corps of Engineers, Portland District, Portland, OR.

Normandeau Associates, Inc., Mid-Columbia Consulting, Inc., and J. R. Skalski. 2004. Direct effects of differential spill volumes on mortality and injury rates of juvenile salmonids at The Dalles Dam spillway, Columbia River in fall 2002 and spring 2003. Report to U.S. Army Corps of Engineers, Portland District, Portland, OR.

Normandeau Associates, Inc. and J. R. Skalski. 2005. Evaluation of training wall on fish condition at The Dalles Dam spillway, Columbia River, 2004. Report to U.S. Army Corps of Engineers, Portland District, Portland, OR. 
Parsley, M. J., C. D. Wright, B. K. van der Leeuw, E. E. Kofoot, C. A. Peery, and M. A. Moser. In Press. White sturgeon (Acipenser transmontanus) passage at The Dalles Dam, Columbia River, USA. Journal of Applied Ichthyology.

Petersen, J. H. and D. L. Ward. 1999. Development and corroboration of a bioenergetics model for northern pikeminnow feeding on juvenile salmonids in the Columbia River. Transactions of the American Fisheries Society 128:784-801.

Peven, C., A. Giorgi, J. Skalski, M. Langeslay, A. Grassell, S. G. Smith, T. Counihan, R. Perry, S. Bickford. 2005. Guidelines and recommended protocols for conducting, analyzing, and reporting juvenile salmonid survival studies in the Columbia River basin. Technical Report, U.S. Army Corps of Engineers.

Ploskey G., T. Poe, A. Giorgi, and G. Johnson. 2001a. Synthesis of Juvenile Salmonid Passage Studies at The Dalles Dam, Volume I: 1982-2000. PNWD-3131, Final report submitted to the U.S. Army Corps of Engineers, Portland District, by Battelle Pacific Northwest Division, Richland, Washington.

Ploskey, G. R., W. T. Nagy, L. R. Lawrence, M. E. Hanks, C. R. Schilt, P. N. Johnson, G. E. Johnson, D. S. Patterson, and J. R. Skalski. 2001b. Hydroacoustic Evaluation of Juvenile Salmon Passage at The Dalles Dam: 1999. ERDC/EL TR-01-11, U.S. Army Engineer Research and Development Center, Vicksburg, Mississippi.

Poe, T. P., H. C. Hansel, S. Vigg, D. E. Palmer, and L. A. Prendergast. 1991. Feeding of predaceous fishes on out-migrating juvenile salmonids in John Day Reservoir, Columbia River. Transactions of the American Fisheries Society 120:405-420.

Probst, W. E., C. F. Rabeni, W. G. Covington, and R. E. Marteney. 1984. Resource use by stream-dwelling rock bass and smallmouth bass. Transactions of the American Fisheries Society 113:283-294.

Puls A. L., T. L. Liedtke, and C. D. Smith. In prep. Survival estimates of migrant juvenile salmonids through The Dalles Dam using radiotelemetry, 2006. Annual Report of Research prepared for the U.S. Army Corps of Engineers, Portland, OR.

Seber, G. A. F. 1965. A note on the multiple recapture census. Biometrika. 52: 249-259.

Sechnick, C. W., R. F. Carline, R. A. Stein, and E. T. Rankin. 1986. Habitat selection by smallmouth bass in response to physical characteristics of a simulated stream. Transactions of the American Fisheries Society 115:314-321.

Sheer, M. B., G. S. Holmberg, R. S. Shively, H. C. Hansel, T. L. Martinelli, T. P. King, C. N. Frost, T. P. Poe, J. C. Snelling, and C. B. Schreck. 1997. Movement and Behavior of Radio-Tagged Juvenile Spring and Fall Chinook Salmon in The Dalles and John Day Dam Forebays, 1995. Annual Report to the U.S. Army Corps of Engineers - Portland District.

Shively, R. S., T. P. Poe, M. B. Sheer, and R. Peters. 1996. Criteria for reducing predation by northern squawfish near juvenile salmonids bypass outfall at Columbia River dams. Regulated Rivers: Research \& Management 12:493-500.

Skalski, J. R., R. Townsend, J. Lady, A.E. Giorgi, J.R. Stevenson, and R.D. McDonald. 2002. Estimating route-specific passage and survival probabilities at a hydroelectric project from smolt radio-telemetry studies. Canadian Journal of Fisheries and Aquatic Sciences. 59: 1385-1393. 
Todd, B. L. and C. F. Rabeni. 1989. Movement and habitat use by stream-dwelling smallmouth bass. Transactions of the American Fisheries Society 118:229-242.

Vigg, S., T. P. Poe, L. A. Prendergast, and H. C. Hansel. 1991. Rates of consumption of juvenile salmonids and alternative prey fish by northern squawfish, walleyes, smallmouth bass, and channel catfish in John Day Reservoir, Columbia River. Transactions of the American Fisheries Society 120:421-438.

Warren, J. J., and L. G. Beckman. 1993. Fishway use by white sturgeon on the Columbia River. Washington Sea Grant Program, Seattle, Washington. WSG-AS-93-02. 


\section{Appendix A}

\section{Technical Reports from Passage Studies}

at The Dalles Dam, 1982-2005 


\section{Appendix A: Technical Reports from Passage Studies at The Dalles Dam, 1982-2005}

The reports listed in the following table are available in PDF files on the compact disk accompanying this synthesis report.

\begin{tabular}{|c|c|c|c|}
\hline CITATION & TITLE & $\begin{array}{l}\text { STUDY } \\
\text { YEAR }\end{array}$ & PDF No \\
\hline Absolon et al. 1995 & Studies to evaluate the effectiveness of extended-length screens at The Dalles Dam, 1994. & 1994 & $\underline{\mathrm{T} 032}$ \\
\hline Absolon et al. 2002 & Relative survival of juvenile salmon passing through the spillway of The Dalles Dam, 1997-2000. & $1997-2000$ & $\underline{\mathrm{T} 037}$ \\
\hline Allen et al. 1999 & $\begin{array}{l}\text { Movement, distribution and behavior of radio-tagged yearling and subyearling Chinook salmon in the } \\
\text { tailrace of The Dalles Dam, } 1999 \text {. }\end{array}$ & 1999 & T069 \\
\hline Allen et al. 2001 & $\begin{array}{l}\text { Monitoring tailrace egress in the stilling basin, the ice-trash sluiceway, and the powerhouse of The Dalles } \\
\text { Dam, } 2000 \text {. }\end{array}$ & 2000 & $\underline{\mathrm{T} 071}$ \\
\hline Beeman et al. 2003 & $\begin{array}{l}\text { Estimates of the stilling basin residence time and lateral distribution of passage of juvenile Chinook salmon } \\
\text { passing through the spillway of The Dalles Dam, } 2001 \text {. }\end{array}$ & 2001 & $\underline{\mathrm{T} 078}$ \\
\hline Beeman et al. 2005a & $\begin{array}{l}\text { Estimates of fish-, spill- and sluiceway passage efficiencies of radio-tagged juvenile steelhead and yearling } \\
\text { Chinook salmon at The Dalles Dam, } 2000 \text {. }\end{array}$ & 2000 & $\underline{\mathrm{T} 072}$ \\
\hline Beeman et al. 2005b & $\begin{array}{l}\text { Estimates of fish-, spill-, and sluiceway passage efficiencies of radio-tagged juvenile fall Chinook salmon at } \\
\text { The Dalles Dam, } 2000 \text {. }\end{array}$ & 2000 & $\underline{\mathrm{T} 073}$ \\
\hline Beeman et al. 2005c & $\begin{array}{l}\text { Estimates of the proportions of radio-tagged juvenile salmonids passing via the spillway, sluiceway, and } \\
\text { turbines during tests of sluiceway guidance improvement devices at The Dalles Dam in } 2001 .\end{array}$ & 2001 & $\underline{\mathrm{T} 077}$ \\
\hline Beeman et al. 2006 & $\begin{array}{l}\text { Estimates of the stilling basin residence time and lateral distribution of juvenile Chinook salmon passing } \\
\text { through the spillway at The Dalles Dam during } 2002 \text {. }\end{array}$ & 2002 & $\underline{\mathrm{T} 080}$ \\
\hline BioSonics, Inc. 1997 & Hydroacoustic evaluation and studies at The Dalles Dam, spring/summer 1996. & 1996 & $\underline{\mathrm{T} 019}$ \\
\hline BioSonics, Inc. 1997 & Hydroacoustic evaluation and studies at The Dalles Dam, spring/summer 1996. Volume 2. Smolt behavior. & 1996 & $\underline{\mathrm{T} 020}$ \\
\hline BioSonics, Inc. 1999 & Hydroacoustic evaluation and studies at The Dalles Dam, spring/summer 1998. & 1998 & $\underline{\mathrm{T} 021}$ \\
\hline Bisson et al. 2001 & Review of studies of fish survival in spill at The Dalles Dam. & 2001 & $\underline{\mathrm{T} 026}$ \\
\hline Bowles 1997 & The Dalles Dam blocked trashrack acoustic Doppler velocimeter mapping. & 1997 & $\underline{\mathrm{T} 023}$ \\
\hline Brege et al. 1997 & Studies to evaluate the effectiveness of extended-length screens at The Dalles Dam, 1995. & 1995 & $\underline{\mathrm{T} 033}$ \\
\hline Cash et al. 2005 & Three-dimensional behavior and passage of juvenile salmonids at The Dalles Dam, 2004. & 2004 & $\underline{\mathrm{T} 085}$ \\
\hline Clugston et al. 1994 & $\begin{array}{l}\text { Movement, distribution, and behavior of juvenile salmonids passing through Columbia and Snake river } \\
\text { dams. }\end{array}$ & 1992 & $\underline{\mathrm{T} 043}$ (in \\
\hline
\end{tabular}




\begin{tabular}{|c|c|c|c|}
\hline CITATION & TITLE & $\begin{array}{l}\text { STUDY } \\
\text { YEAR }\end{array}$ & PDF No \\
\hline Counihan et al. 2002a & $\begin{array}{l}\text { Survival estimates of migrant juvenile salmonids in the Columbia River from John Day Dam through } \\
\text { Bonneville Dam using radio telemetry, } 2000 .\end{array}$ & 2000 & $\underline{\mathrm{T} 074}$ \\
\hline Counihan et al. $2002 b$ & $\begin{array}{l}\text { Survival estimates of migrant juvenile salmonids through The Dalles Dam ice and trash sluiceway using } \\
\text { radio-telemetry, } 2001 \text {. }\end{array}$ & 2001 & $\underline{\mathrm{T} 079}$ \\
\hline Counihan et al. 2006a & Survival estimates of migrant juvenile salmonids through The Dalles Dam using radio telemetry, 2002. & 2002 & $\underline{\mathrm{T} 081}$ \\
\hline Counihan et al. 2006b & $\begin{array}{l}\text { Survival estimates of migrant juvenile salmonids in the Columbia River through The Dalles Dam using radio } \\
\text { telemetry, } 2004 .\end{array}$ & 2004 & $\underline{\mathrm{T} 086}$ \\
\hline Counihan et al. 2006c & Survival estimates of migrant juvenile salmonids through The Dalles Dam using radio telemetry, 2005. & 2005 & $\underline{\mathrm{T} 088}$ \\
\hline Coutant et al. 2000 & Fish behavior in relation to passage through hydropower turbines: a review. & $\mathrm{n} / \mathrm{a}$ & $\underline{\mathrm{T} 092}$ \\
\hline Dawley et al. 1998 & Relative survival of juvenile salmon passing through the spillway of The Dalles Dam, 1997. & 1997 & $\underline{\mathrm{T} 034}$ \\
\hline Dawley et al. 2000a & $\begin{array}{l}\text { Relative survival of juvenile salmon passing through the spillway and the ice and trash sluiceway of The } \\
\text { Dalles Dam, } 1998 .\end{array}$ & 1998 & $\underline{\mathrm{T} 035}$ \\
\hline Dawley et al. 2000b & Relative survival of juvenile salmon passing through the spillway of The Dalles Dam, 1999. & 1999 & $\underline{\mathrm{T} 036}$ \\
\hline DeHart 2002 & Fish Passage Center Annual Report, 2001. & 2001 & $\underline{\mathrm{T} 024}$ \\
\hline Duran et al. 2003 & Predator-prey interactions in The Dalles Dam tailrace, 2002. & 2002 & $\underline{\mathrm{T} 082}$ \\
\hline Ebberts 1992 & $\begin{array}{l}\text { Summary review of horizontal and temporal distribution of juvenile salmonids across the powerhouse and } \\
\text { spillway of The Dalles Dam from hydroacoustic studies }(1982,1985,1986 \text { and 1989). }\end{array}$ & 1982-1989 & $\underline{\mathrm{T} 048}$ \\
\hline ENSR 2001 & $\begin{array}{l}\text { Three-Dimensional Computational Fluid Dynamics (CFD) Modeling of the Forebay of The Dalles Dam, } \\
\text { Oregon. }\end{array}$ & $\mathrm{n} / \mathrm{a}$ & \\
\hline Faber et al. 2005 & The distribution and flux of fish in the forebay of The Dalles Dam in 2003. & 2003 & $\underline{\mathrm{T} 013}$ \\
\hline Ferguson et al. 2003 & Passage of juvenile and adult salmonids at Columbia and Snake River Dams. & $\mathrm{n} / \mathrm{a}$ & $\underline{\mathrm{T} 029}$ \\
\hline Ferguson et al. 2005 & Passage of adult and juvenile salmonids through Federal Columbia River Power System dams. & $\mathrm{n} / \mathrm{a}$ & $\underline{\mathrm{T} 030}$ \\
\hline Guensch et al. 2004 & Prototype measurements of pressure fluctuations in The Dalles Dam stilling basin. & 2004 & $\underline{\mathrm{T} 002}$ \\
\hline Hansel et al. 2000 & $\begin{array}{l}\text { Estimates of fish-, spill- and sluiceway passage efficiencies of radio-tagged juvenile steelhead and yearling } \\
\text { Chinook salmon at The Dalles Dam, } 1999 .\end{array}$ & 1999 & $\underline{\mathrm{T} 070}$ \\
\hline Hansel et al. 2004 & $\begin{array}{l}\text { Estimates of fish, spill and sluiceway passage efficiencies of radio-tagged juvenile Chinook salmon at The } \\
\text { Dalles Dam in } 2003 .\end{array}$ & 2003 & $\underline{\mathrm{T} 084}$ \\
\hline Hansel et al. 2005 & $\begin{array}{l}\text { Estimates of fish, spill and sluiceway passage efficiencies of radio-tagged juvenile Chinook salmon during } \\
\text { spring and summer at The Dalles Dam in } 2004 \text {. }\end{array}$ & 2004 & $\underline{\mathrm{T} 087}$ \\
\hline
\end{tabular}




\begin{tabular}{|c|c|c|c|}
\hline CITATION & TITLE & $\begin{array}{l}\text { STUDY } \\
\text { YEAR }\end{array}$ & PDF No \\
\hline Hansel et al. 2007 & $\begin{array}{l}\text { Estimates of fish, spill and sluiceway passage efficiencies of radio-tagged juvenile Chinook salmon during } \\
\text { spring and summer at The Dalles Dam in } 2005 \text {. }\end{array}$ & 2005 & $\underline{\mathrm{T} 089}$ \\
\hline Hausmann et al. 2004 & $\begin{array}{l}\text { Estimates of fish, spill, and sluiceway passage efficiencies of radio-tagged juvenile salmonids relative to } \\
\text { operation of the sluiceway guidance improvement device at The Dalles Dam in } 2002 .\end{array}$ & 2002 & $\underline{\mathrm{T} 083}$ \\
\hline Hawkes et al. 1991 & Monitoring of downstream salmon and steelhead at federal hydroelectric facilities. & 1990 & $\underline{\mathrm{T} 031}$ \\
\hline Hedgepeth et al. 2001 & Active fish tracking sonar (AFTS) for assessing fish behavior. & 2001 & $\underline{\mathrm{T} 008}$ \\
\hline Hedgepeth et al. 2002 & Sonar tracker evaluation of fish movements relative to j-occlusions at The Dalles Dam in 2001. & 2001 & $\underline{\mathrm{T} 009}$ \\
\hline Hensleigh et al. 1999 & $\begin{array}{l}\text { Movement, distribution and behavior of radio-tagged juvenile Chinook salmon and steelhead in John Day, } \\
\text { The Dalles and Bonneville dam forebays, } 1997 .\end{array}$ & 1997 & $\underline{\mathrm{T} 068}$ \\
\hline Holmberg et al. 1997 & $\begin{array}{l}\text { Movement, distribution and behavior of radio-tagged juvenile Chinook salmon and steelhead in John Day, } \\
\text { The Dalles and Bonneville dam forebays, } 1996 .\end{array}$ & 1996 & $\underline{\mathrm{T} 067}$ \\
\hline INCA et al. 1999 & The Dalles Dam combined system. & 1999 & $\underline{\mathrm{T} 025}$ \\
\hline Johnson et al. 1987 & Hydroacoustic evaluation of the spill program for fish passage at The Dalles Dam in 1986. & 1987 & $\underline{\mathrm{T} 001}$ \\
\hline Johnson et al. 2000 & $\begin{array}{l}\text { Assessment of the acoustic screen model to estimate smolt passage rates at dams: case study at The Dalles } \\
\text { Dam in } 1999 .\end{array}$ & 1999 & $\underline{\mathrm{T} 016}$ \\
\hline Johnson et al. 2001 & $\begin{array}{l}\text { Evaluation of smolt movements using an active fish tracking sonar at the sluiceway surface bypass, The } \\
\text { Dalles Dam, } 2000 .\end{array}$ & 2000 & $\underline{\mathrm{T} 017}$ \\
\hline Johnson et al. 2003a & Hydroacoustic evaluation of turbine intake J-occlusions at The Dalles Dam in 2002. & 2002 & $\underline{\mathrm{T} 011}$ \\
\hline Johnson et al. 2003b & Hydroacoustic evaluation of turbine intake J-occlusions at The Dalles Dam in 2002-Appendices. & 2002 & $\underline{\mathrm{T} 012}$ \\
\hline Johnson et al. 2005 & Hydroacoustic evaluation of juvenile salmon passage at The Dalles Dam in 2004. & 2004 & $\underline{\mathrm{T} 014}$ \\
\hline Johnson et al. 2006 & Hydroacoustic evaluation of juvenile salmon passage at The Dalles Dam sluiceway, 2005. & 2005 & $\underline{\mathrm{T} 015}$ \\
\hline Jones et al. 1996 & $\begin{array}{l}\text { Predation by gulls and effectiveness of predation control measures at Bonneville, The Dalles and John Day } \\
\text { dams in } 1995 .\end{array}$ & 1995 & $\underline{\mathrm{T} 056}$ \\
\hline Jones et al. 1997 & $\begin{array}{l}\text { Predation by gulls and effectiveness of predation control measures at Bonneville, The Dalles and John Day } \\
\text { dams in } 1996 .\end{array}$ & 1996 & $\underline{\mathrm{T} 058}$ \\
\hline Jones et al. 1998 & $\begin{array}{l}\text { Predation by birds and effectiveness of predation control measures at Bonneville, The Dalles and John Day } \\
\text { dams in } 1997 .\end{array}$ & 1997 & $\underline{\mathrm{T} 059}$ \\
\hline Jones et al. 1999 & $\begin{array}{l}\text { Predation by birds and effectiveness of predation control measures at Bonneville, The Dalles and John Day } \\
\text { dams. }\end{array}$ & 1998 & $\underline{\mathrm{T} 060}$ \\
\hline
\end{tabular}




\begin{tabular}{|c|c|c|c|}
\hline CITATION & TITLE & $\begin{array}{l}\text { STUDY } \\
\text { YEAR }\end{array}$ & PDF No \\
\hline Magne et al. 1983 & $\begin{array}{l}\text { Hydroacoustic monitoring of downstream migrant juvenile salmonid passage at John Day and The Dalles } \\
\text { Dams in } 1982 .\end{array}$ & 1983 & $\underline{\mathrm{T} 053}$ \\
\hline McFadden 1990 & Hydroacoustic evaluation of juvenile salmonid fish passage at The Dalles Dam in summer 1989. & 1989 & $\underline{\mathrm{T} 018}$ \\
\hline MGS 1999 & Summary report hydrographic survey the Columbia River Oregon and Washington: The Dalles Dam. & 1999 & $\underline{\mathrm{T} 027}$ \\
\hline Moursund et al. 2001 & Hydroacoustic evaluation of downstream fish passage at The Dalles Dam in 2000. & 2000 & $\underline{\mathrm{T} 007}$ \\
\hline Moursund et al. 2002 & Hydroacoustic evaluation of fish passage at The Dalles Dam in 2001. & 2001 & $\underline{\mathrm{T} 010}$ \\
\hline $\begin{array}{l}\text { Nagy and Shutters } \\
1995\end{array}$ & Hydroacoustic evaluation of surface collector prototypes at The Dalles Dam, 1995. & 1995 & $\underline{\mathrm{T} 057}$ \\
\hline $\begin{array}{l}\text { Nestler and Davidson } \\
1995\end{array}$ & $\begin{array}{l}\text { Imaging smolt behavior on an extended-length submerged bar screen and an extended-length submerged } \\
\text { traveling screen at The Dalles Dam in } 1993 \text {. }\end{array}$ & 1993 & $\underline{\mathrm{T} 055}$ \\
\hline $\begin{array}{l}\text { Nichols and Ransom } \\
1982\end{array}$ & Development of The Dalles Dam trash sluiceway as a downstream migrant bypass system, 1981. & 1981 & $\underline{\mathrm{T} 046}$ \\
\hline NMFS 2000 & Passage of juvenile and adult salmonids past Columbia and Snake River dams. & $\mathrm{n} / \mathrm{a}$ & $\underline{\mathrm{T} 028}$ \\
\hline $\begin{array}{l}\text { Normandeau et al. } \\
1996\end{array}$ & $\begin{array}{l}\text { Potential effects of modified spillbay configurations on fish condition and survival at The Dalles Dam, } \\
\text { Columbia River. }\end{array}$ & 1996 & $\underline{\mathrm{T} 038}$ \\
\hline $\begin{array}{l}\text { Normandeau and Mid- } \\
\text { Columbia Consulting } \\
2001\end{array}$ & $\begin{array}{l}\text { Feasibility of estimating direct mortality and injury on juvenile salmonids passing The Dalles Dam spillway } \\
\text { during high discharge. }\end{array}$ & 2001 & $\underline{\mathrm{T} 039}$ \\
\hline $\begin{array}{l}\text { Normandeau et al. } \\
2003\end{array}$ & $\begin{array}{l}\text { Estimated direct mortality and injury rate of juvenile salmonids in passage through The Dalles Dam } \\
\text { spillway, Columbia river in spring and summer } 2002 .\end{array}$ & 2002 & $\underline{\mathrm{T} 040}$ \\
\hline $\begin{array}{l}\text { Normandeau et al. } \\
2004\end{array}$ & $\begin{array}{l}\text { Direct effects of differential spill volumes on mortality and injury rates of juvenile salmonids at The Dalles } \\
\text { Dam spillway in fall } 2002 \text { and spring } 2003 \text {. }\end{array}$ & $2002-2003$ & $\underline{\mathrm{T} 041}$ \\
\hline $\begin{array}{l}\text { Normandeau et al. } \\
2005\end{array}$ & Evaluation of training wall on fish condition at The Dalles Dam spillway, Columbia River, 2004. & 2004 & $\underline{\mathrm{T} 042}$ \\
\hline Petersen et al. 2001 & Predation by northern pike minnow on juvenile salmonids in The Dalles Dam tailrace. & 2000 & $\underline{\mathrm{T} 075}$ \\
\hline Ploskey et al. 2001a & $\begin{array}{l}\text { Synthesis of radio telemetry, hydroacoustic, and survival studies of juvenile salmon at The Dalles Dam } \\
(1982-2000) \text {. }\end{array}$ & $1982-2000$ & $\underline{\mathrm{T} 003}$ \\
\hline Ploskey et al. 2001b & Hydroacoustic evaluation of juvenile salmon passage at The Dalles Dam: 1999. & 1999 & $\underline{\mathrm{T} 006}$ \\
\hline Ploskey, G.R. & The Dalles Dam ice and trash sluiceway--notes on hydroacoustic monitoring. & $\mathrm{n} / \mathrm{a}$ & $\underline{\mathrm{T} 004}$ \\
\hline
\end{tabular}




\begin{tabular}{|c|c|c|c|}
\hline CITATION & TITLE & $\begin{array}{l}\text { STUDY } \\
\text { YEAR }\end{array}$ & PDF No. \\
\hline $\begin{array}{l}\text { Poe and Gadomski } \\
1994\end{array}$ & $\begin{array}{l}\text { Significance of selective predation and development of prey protection measures for juvenile salmonids in } \\
\text { the Columbia and Snake reservoirs: Annual report for Feb } 1992-\text { Feb } 1993 .\end{array}$ & 1992 & $\underline{\mathrm{T} 063}$ \\
\hline Poe 1995 & $\begin{array}{l}\text { Significance of selective predation and development of prey protection measures for juvenile salmonids in } \\
\text { the Columbia and Snake reservoirs } 1993 \text {. }\end{array}$ & 1993 & $\underline{\mathrm{T} 064}$ \\
\hline Richmond et al. & Characterization of The Dalles spillway environment - presentation. & $\mathrm{n} / \mathrm{a}$ & $\underline{\mathrm{T} 005}$ \\
\hline Sheer et al. 1997 & $\begin{array}{l}\text { Movement and behavior of radio-tagged juvenile spring and fall Chinook salmon in The Dalles and John } \\
\text { Day dam forebays, } 1995 \text {. }\end{array}$ & 1995 & $\underline{\mathrm{T} 066}$ \\
\hline Snelling et al. 1997 & Behavior and fate of juvenile salmonids entering the tailwaters of The Dalles Dam via spill. & 1997 & $\underline{\mathrm{T} 045}$ \\
\hline Stansell et al. 1991 & $\begin{array}{l}\text { Hydroacoustic evaluation of juvenile salmonid fish passage at The Dalles Dam fish attraction water units in } \\
1990 .\end{array}$ & 1990 & $\underline{\mathrm{T} 054}$ \\
\hline Steig and Johnson 1986 & $\begin{array}{l}\text { Hydroacoustic assessment of downstream migrating salmonids at The Dalles Dam in spring and summer } \\
1985 .\end{array}$ & 1985 & $\underline{\mathrm{T} 022}$ \\
\hline USACE 2001 & Design and documentation report for TDA sluiceway, 2001. & 2001 & $\underline{\mathrm{T} 061}$ \\
\hline USACE 1992 & The Dalles Dam juvenile bypass system. & 1991 & $\underline{\mathrm{T} 047}$ \\
\hline USACE 1996 & Memorandum--summary on Dalles 6-bay spillway 1:40 scale. & $\mathrm{n} / \mathrm{a}$ & $\underline{\mathrm{T} 052}$ \\
\hline USACE 1997 & Letter Report--The Dalles Lock and Dam: ice and trash sluiceway outfall locations study. & 1997 & $\underline{\mathrm{T} 049}$ \\
\hline USACE 2006 & The Dalles Lock and Dam juvenile bypass behavioral guidance system (BGS). & 2006 & $\underline{\mathrm{T} 051}$ \\
\hline USACE 2006 & Letter Report—The Dalles Lock and Dam Spillway Redistribution Vortex Suppression Device. & 2006 & $\underline{\mathrm{T} 050}$ \\
\hline Ward et al. 2004 & $\begin{array}{l}\text { Resident fish in the Columbia River basin: Restoration, enhancement, and mitigation for losses associated } \\
\text { with hydroelectric development and operations. }\end{array}$ & $\mathrm{n} / \mathrm{a}$ & $\underline{\mathrm{T} 093}$ \\
\hline
\end{tabular}




\section{Appendix B}

\section{Forebay Approach and Residence Time Results}




\section{Appendix B}

\section{Forebay Approach and Residence Time Results}

Results are averages of median residence times and percent detected approaching via several areas within $100 \mathrm{~m}$ of the dam. East powerhouse is main units 12 and greater in number, west powerhouse is fish unit 1 to main unit 11 . North spillway is bays 1 to 11 , south spillway is bays 12 to 23 . NR = not reported, NA $=$ not applicable, ${ }^{1}=2004$ acoustic tagged fish only.

\begin{tabular}{|c|c|c|c|c|c|c|c|c|c|c|}
\hline \multirow[b]{2}{*}{ Species } & \multirow[b]{2}{*}{ Treatment } & \multirow{2}{*}{$\begin{array}{l}\text { Sample Size } \\
\text { for approach } \\
\text { (for res time) }\end{array}$} & \multirow{2}{*}{$\begin{array}{l}\text { Median } \\
\text { Forebay } \\
\text { Residence } \\
\text { time }(\mathrm{h})\end{array}$} & \multicolumn{2}{|c|}{$\begin{array}{c}\text { Powerhouse } \\
\text { Approach Area }\end{array}$} & \multicolumn{2}{|c|}{$\begin{array}{c}\text { Spillway } \\
\text { Approach Area } \\
\end{array}$} & \multirow{2}{*}{$\begin{array}{c}\text { Mean } \\
\text { Percent } \\
\text { Spill } \\
\end{array}$} & \multicolumn{2}{|c|}{$\begin{array}{c}\text { Mean Average Hourly } \\
\text { Discharge, kcfs }\end{array}$} \\
\hline & & & & East & West & South & North & & Spill & Total \\
\hline \multicolumn{11}{|c|}{2001 (Beeman et al. 2005) } \\
\hline STH & Day spill & $160(225)$ & 2.4 & 16.9 & 17.5 & \multicolumn{2}{|c|}{65.6} & 30.7 & 46 & 149 \\
\hline STH & Day no spill & $68(125)$ & 10.2 & 36.8 & 30.9 & \multicolumn{2}{|c|}{32.4} & 0 & 0 & 125 \\
\hline STH & Night spill & $146(144)$ & 1.4 & 15.1 & 22.6 & \multicolumn{2}{|c|}{62.3} & 30.2 & 41 & 135 \\
\hline STH & Night no spill & $94(89)$ & 6.4 & 39.4 & 22.3 & \multicolumn{2}{|c|}{38.3} & 0 & 0 & 106 \\
\hline $\mathrm{CH} 1$ & Day spill & $187(216)$ & 0.7 & 11.2 & 14.4 & \multicolumn{2}{|c|}{74.3} & 30.7 & 46 & 149 \\
\hline $\mathrm{CH} 1$ & Day no spill & $69(120)$ & 2.5 & 33.3 & 42.0 & \multicolumn{2}{|c|}{24.6} & 0 & 0 & 125 \\
\hline $\mathrm{CH} 1$ & Night spill & $100(159)$ & 0.7 & 9.0 & 27.0 & \multicolumn{2}{|c|}{64.0} & 30.2 & 41 & 135 \\
\hline $\mathrm{CH} 1$ & Night no spill & $70(83)$ & 1.4 & 30.0 & 42.9 & \multicolumn{2}{|c|}{27.1} & 0 & 0 & 106 \\
\hline $\mathrm{CH} 0$ & Day & $293(419)$ & 1.1 & 43.7 & 41.3 & \multicolumn{2}{|c|}{15.0} & 0 & 0 & 110 \\
\hline $\mathrm{CH} 0$ & Night & $186(283)$ & 1.8 & 39.8 & 45.2 & \multicolumn{2}{|c|}{15.0} & 0 & 0 & 93 \\
\hline \multicolumn{11}{|c|}{2002 (Hausman et al. 2004) } \\
\hline STH & Day & $1523(1702)$ & 0.50 & \multicolumn{2}{|c|}{35.4} & \multicolumn{2}{|c|}{64.6} & 37.1 & 94 & 254 \\
\hline STH & Night & $348(382)$ & 0.23 & \multicolumn{2}{|c|}{46.6} & \multicolumn{2}{|c|}{53.4} & 40.4 & 100 & 247 \\
\hline CH1 & Day & $1348(1496)$ & 0.16 & \multicolumn{2}{|c|}{51.9} & \multicolumn{2}{|c|}{48.1} & 37.1 & 94 & 254 \\
\hline $\mathrm{CH} 1$ & Night & $581(696)$ & 0.19 & \multicolumn{2}{|c|}{38.0} & \multicolumn{2}{|c|}{62.0} & 40.4 & 100 & 247 \\
\hline $\mathrm{CHO}$ & Day & $2020(2016)$ & 0.10 & 48.8 & 14.6 & \multicolumn{2}{|c|}{36.6} & 36.0 & 103 & 285 \\
\hline $\mathrm{CHO}$ & Night & $834(950)$ & 0.04 & 29.6 & 14.4 & \multicolumn{2}{|c|}{56.0} & 41.9 & 110 & 262 \\
\hline & & & 2003-2005 & nsel et & 4, 2005 & Cash et & & & & \\
\hline $\mathrm{STH}^{1}$ & Overall & $343(258)$ & 0.8 & NR & NR & NR & NR & NR & 40 & 74.3 \\
\hline $\mathrm{CH} 1$ & Day & NA & 0.30 & 11.7 & 21.6 & 13.2 & 53.5 & 37.7 & 84.7 & 225.0 \\
\hline $\mathrm{CH} 1$ & Night & NA & 0.26 & 9.4 & 22.4 & 9.2 & 59.3 & 38.3 & 81.0 & 211.7 \\
\hline $\mathrm{CHO}$ & Day & NA & 0.31 & 16.0 & 26.0 & 10.3 & 47.7 & 39.0 & 65.3 & 167.7 \\
\hline $\mathrm{CHO}$ & Night & NA & 0.36 & 12.3 & 28.3 & 7.3 & 52.0 & 40.7 & 59.3 & 146.3 \\
\hline $\mathrm{SOC}^{1}$ & Overall & $449(514)$ & 0.6 & NR & NR & NR & NR & 40 & 47.0 & $91.7-319.1$ \\
\hline
\end{tabular}


Residence time was measured from first detection at the transect of three barges across from MU 18 (see Figure 3.1) to the last forebay detection. The data in the following table are summarized across years in Table 3.1.

\begin{tabular}{|c|c|c|c|c|c|c|c|c|c|}
\hline \multirow[b]{2}{*}{ Species } & \multirow[b]{2}{*}{ Treatment } & \multicolumn{2}{|c|}{ Powerhouse } & \multicolumn{2}{|c|}{ Sluiceway } & \multicolumn{2}{|c|}{ Spillway } & \multicolumn{2}{|c|}{ Overall } \\
\hline & & $\mathrm{N}$ & Median & $\mathrm{N}$ & Median & $\mathrm{N}$ & Median & $\mathrm{N}$ & Median \\
\hline \multicolumn{10}{|c|}{2003} \\
\hline $\mathrm{CH} 1$ & Day & 33 & 0.23 & 123 & 0.35 & 265 & 0.68 & 421 & 0.53 \\
\hline $\mathrm{CH} 1$ & Night & 36 & 0.17 & 56 & 0.36 & 82 & 0.71 & 174 & 0.50 \\
\hline $\mathrm{CH} 1$ & Overall & 69 & 0.18 & 179 & 0.35 & 347 & 0.68 & 595 & 0.51 \\
\hline $\mathrm{CHO}$ & Day & 41 & 0.31 & 231 & 0.4 & 1458 & 0.72 & 1730 & 0.68 \\
\hline $\mathrm{CHO}$ & Night & 153 & 0.3 & 123 & 0.46 & 377 & 1.01 & 653 & 0.76 \\
\hline $\mathrm{CHO}$ & Overall & 194 & 0.31 & 354 & 0.42 & 1835 & 0.78 & 2383 & 0.69 \\
\hline \multicolumn{10}{|c|}{2004} \\
\hline $\mathrm{CH} 1$ & Day & 10 & 0.25 & 74 & 0.34 & 923 & 0.65 & 1007 & 0.54 \\
\hline $\mathrm{CH} 1$ & Night & 40 & 0.28 & 62 & 0.48 & 284 & 0.85 & 387 & 0.74 \\
\hline CH1 & Overall & 50 & 0.86 & 136 & 0.39 & 1207 & 0.61 & 1394 & 0.58 \\
\hline $\mathrm{CHO}$ & Day & 31 & 0.26 & 69 & 0.39 & 680 & 0.59 & 780 & 0.57 \\
\hline $\mathrm{CHO}$ & Night & 87 & 0.39 & 29 & 0.58 & 249 & 1.06 & 365 & 0.84 \\
\hline $\mathrm{CHO}$ & Overall & 118 & 0.32 & 98 & 0.43 & 929 & 0.67 & 1145 & 0.62 \\
\hline \multicolumn{10}{|c|}{2005} \\
\hline $\mathrm{CH} 1$ & Day & 32 & 0.27 & 86 & 0.38 & 493 & 0.73 & 611 & 0.65 \\
\hline $\mathrm{CH} 1$ & Night & 32 & 0.3 & 47 & 0.51 & 213 & 0.94 & 292 & 0.80 \\
\hline $\mathrm{CH} 1$ & Overall & 64 & 0.29 & 133 & 0.43 & 706 & 0.78 & 903 & 0.70 \\
\hline $\mathrm{CHO}$ & Day & 38 & 0.29 & 18 & 0.52 & 411 & 0.62 & 467 & 0.60 \\
\hline CHO & Night & 73 & 0.34 & 32 & 0.57 & 228 & 1.05 & 333 & 0.83 \\
\hline $\mathrm{CH} 0$ & Overall & 111 & 0.32 & 50 & 0.54 & 639 & 0.71 & 800 & 0.65 \\
\hline
\end{tabular}




\section{Appendix C}

\section{Passage Efficiency and Effectiveness of Tagged Juvenile Salmonids at The Dalles Dam}




\section{Appendix C}

\section{Passage Efficiency and Effectiveness of Tagged Juvenile Salmonids at The Dalles Dam}

Data are from radio (2001-2005) and acoustic (2004 only) telemetry from 2001 through 2005. Efficiency is the percent of tagged fish passage per route out of total project passage. Effectiveness is the ratio of efficiency to the percentage of total discharge through a route. The fish passage efficiency (FPE) is the percent of non-turbine passage. $\mathrm{NR}=$ not reported. * Average for study period. ** 2001 passage efficiencies are averaged across treatments. ***Assuming $4.3 \mathrm{kcfs}$ (2001), $3.8 \mathrm{kcfs}$ (2002) discharge through sluiceway, no estimate for 2003; $2.2 \%$ (spring) and 2.4\% (summer) of total project discharge in $2004,3.3 \%$ (spring) and 3.8\% (summer) of total project discharge in 2005 (from hydroacoustic study reports).

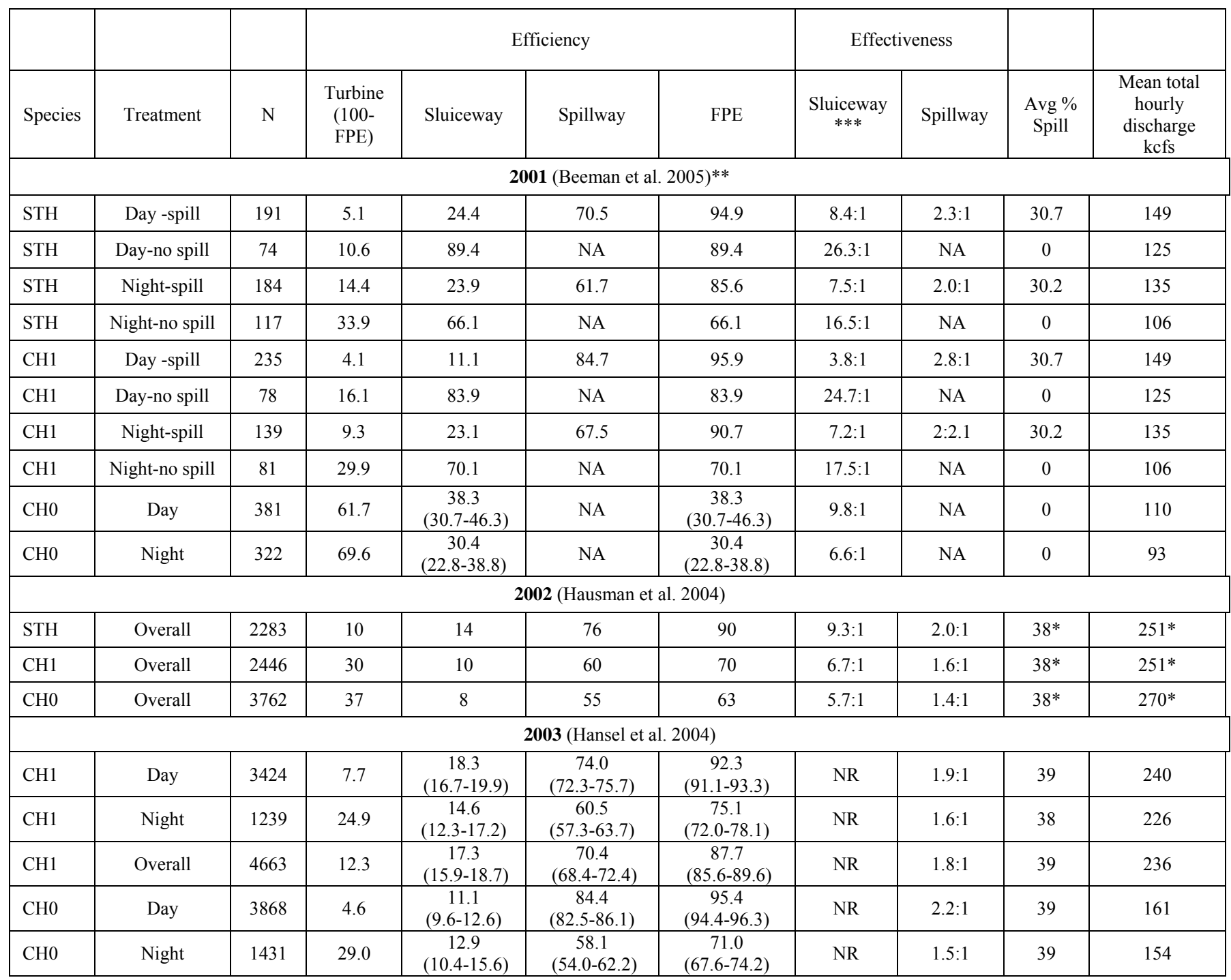




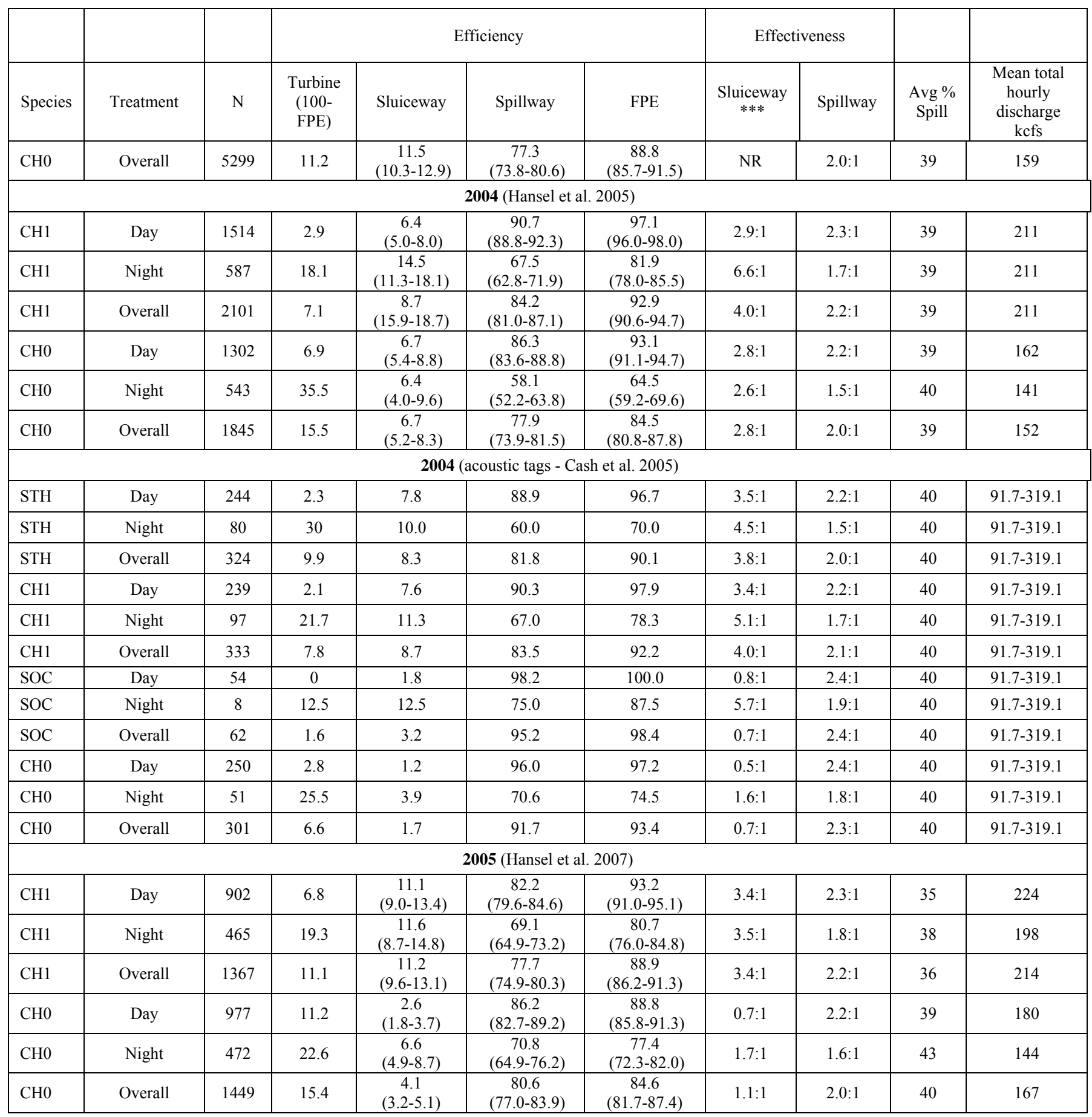




\title{
Appendix D
}

\section{Regression Analysis of Spillbay Passage at The Dalles Dam}

\author{
July 19, 2007 \\ Prepared for: \\ Gary Johnson \\ Pacific Northwest National Laboratory \\ Marine Sciences Laboratory \\ 620 SW Fifth Avenue, Suite 810 \\ Portland, Oregon 97204 \\ Prepared by: \\ John R. Skalski \\ Jim Griswold \\ Columbia Basin Research \\ School of Aquatic and Fishery Sciences \\ University of Washington \\ 1325 Fourth Avenue, Suite 1820 \\ Seattle, Washington 98101
}




\section{Introduction}

The purpose of this report is to examine the influence of spill at The Dalles Dam on the passage of salmonid smolts through the spillway. Multiple regression analysis (Draper and Smith 1998, Kutner et al. 2004) was used to determine whether spill variables explains the daily variation in smolt passage through the spillway for the years 1999, 2001-2002, and 2004.

Three alternative response variables regarding spill passage of smolts at The Dalles Dam were considered; these were:

1. SP: abundance expressed as number of smolts/day.

2. SE: spill efficiency expressed as the proportion

$$
S E=\frac{S P}{S P+T}
$$

where $T=$ number of turbine passed smolts/day.

3. SN: spill effectiveness expressed as the odd's ratio

$$
S N=\frac{\left(\frac{S P}{S P+T}\right)}{\left(\frac{F_{S P}}{F_{S P}+F_{T}}\right)}=S E \cdot\left(\frac{F_{S P}+F_{T}}{F_{S P}}\right)
$$

where $F_{S P}=$ flow volume through spillway/day and $F_{T}=$ flow volume through turbines/day.

Weighted regression was used to examine the relationship between these dependent variables and a series of covariates. The weights used in the regression were inversely proportional to the variance of the response variable, i.e.,

$$
\text { Weight }(\hat{\theta})=\frac{1}{\operatorname{Var}(\hat{\theta})} \text {. }
$$

Two types of regression analyses were performed; these were:

1. Stepwise regression

2. Hierarchical regression

The environmental covariates used in the regression against spill passage metrics included:
a. J-Block presence or absence (i.e., 0 or 1 )
b. Julian date $(J D)$, and $J D^{2}$ and $J D^{3}$
c. Temperature (T)
d. Forebay elevation (FE)

and flow parameters
e. $F_{S P}$ 


$$
\text { f. } \frac{F_{S P}}{F_{S P}+F_{T}+F_{S L}}=P_{S P}
$$

where $F_{S L}=$ flow volume through the sluiceway.

In stepwise regression, covariates were allowed to enter or leave the model regardless of what they were. The $\alpha$-level for entry or removal from a model was 0.05 . The purpose for the analysis was to find the best fit model regardless of composition. In hierarchical regression, non-flow-related parameters were incorporated into the model, followed by relevant flow parameters. The purpose was to see if flow explained spill passage after all other ambient factors were considered.

\section{Results}

\section{Spill Passage Abundance (SP) \\ Stepwise Regression}

Four variables entered the multiple regression model at $P<0.05$; these were $\mathrm{J}$ block, forebay elevation, spill volume $\left(F_{S P}\right)$, and proportion spill $\left(P_{S P}\right)$ (Table 1$)$. The multiple $r^{2}$ for the model was 0.407 , indicating the regression model explained approximately $41 \%$ of the total variation in spill passage abundance $(S P)$.

Table 1. ANOVA table for sequential stepwise regression model for fish abundance through the spillway $(N)$

\begin{tabular}{lccccc}
\hline \multicolumn{1}{c}{ Source } & DF & SS & MS & $F$ & $P$ \\
\hline Total $_{\text {COR }}$ & 258 & 67216.2 & & & \\
J block & 1 & 22317.8 & 22317.2 & $F_{1,257}=127.75$ & $\approx 0$ \\
$\quad$ Error & 257 & 44898.4 & 174.7 & & \\
Forebay elevation & 1 & 3582.2 & 3582.2 & $F_{1,256}=22.20$ & $\approx 0$ \\
$\quad$ Error & 256 & 41316.2 & 161.39 & & \\
$P_{S P}$ & 1 & 1477.2 & 1477.2 & $F_{1,255}=9.455$ & 0.0023 \\
$\quad$ Error & 255 & 39839.0 & 156.23 & & \\
$F_{S P}$ & 1 & 805.1 & 805.1 & $F_{1,254}=5.2389$ & 0.0229 \\
$\quad$ Error & 254 & 39033.9 & 154.68 & & \\
\hline
\end{tabular}

\section{Hierarchical Regression}

Using the environmental covariates (i.e., J block, forebay elevation) found significant in the stepwise regression of Section 2.1.1., hierarchical regression was used to examine the significance of spill parameters. The hierarchical $F$ tests found spill fraction $P_{S P}$ to be significant $(P=0.0023)$ but not spill volume $F_{S P}(P=0.6611)$. Although $P_{S P}$ was significant, it increased the $r^{2}$ for the model with environmental covariates only from 0.385 to 0.407 with spill fraction (Table 2). Hence, spill fraction has little biological significance despite statistical significance. 
Table 2. Hierarchical regression for $N$, testing the significance of $F_{S P}$ and $P_{S P}$ after accounting for environmental covariates..

\begin{tabular}{lcccccc}
\hline \multicolumn{1}{c}{ Source } & DF & SS & MS & $F$ & $P$ & $r^{2}$ \\
\hline Total $_{\text {COR }}$ & 258 & 67216.2 & & & & \\
Env. covariates* & 2 & 25900.0 & 12590.0 & $F_{2,256}=78.00$ & $\approx 0$ & 0.385 \\
Error & 256 & 41316.2 & 161.39 & & & \\
$F_{S P}$ & 1 & 31.2 & 31.2 & $F_{1,255}=0.1927$ & 0.6611 & 0.386 \\
Error & 255 & 41285.0 & 161.91 & & & \\
$P_{S P}$ & 1 & 1477.2 & 1477.2 & $F_{1,255}=9.4552$ & 0.0023 & 0.407 \\
Error & 255 & 39839.0 & 156.2 & & & \\
\hline
\end{tabular}

* Environmental covariates entered into model: J block and forebay elevation.

\section{Spill Efficiency (SE)}

The same four environmental covariates and two spill covariates used in Section 2.1 were also investigated in relationship to spill efficiency.

\section{Stepwise Regression}

Stepwise regression found three covariates significant $(P<0.05)$; water temperature, Julian date $(J D)$, and spill fraction $\left(P_{S P}\right)$ in describing the daily variation in spill efficiency (Table 3). The overall model explained an $r^{2}=0.606$.

Table 3. ANOVA table for sequential stepwise regression model for spill efficiency (SE)

\begin{tabular}{crrrrr}
\hline Source & DF & \multicolumn{1}{c}{ SS } & \multicolumn{1}{c}{ MS } & \multicolumn{1}{c}{$F$} & $P$ \\
\hline Total $_{\text {COR }}$ & 258 & 80588.50 & & & \\
Temperature & 1 & 511.40 & 511.40 & $F_{1,257}=1.64$ & 0.044 \\
Error & 257 & 80077.10 & 311.58 & & \\
Julian date & 1 & 44260.93 & 44261.93 & $F_{1,256}=316.36$ & $\approx 0$ \\
Error & 256 & 35816.17 & 139.91 & & \\
$P_{S P}$ & 1 & 4052.72 & 4052.72 & $F_{1,253}=32.54$ & $\approx 0$ \\
Error & 255 & 31763.45 & 124.56 & & \\
\hline
\end{tabular}

\section{Hierarchical Regression}

Because the spill fraction $\left(P_{S P}\right)$ entered the stepwise regression last, the sequential $F$ is equivalent to the hierarchical test of significance. The effect of spill fraction $\left(P_{S P}\right)$ was found to be significant $(P \approx 0)$, while spill volume was not $(P=0.82)$ after accounting for water temperature and Julian date $(J D)$ (Table 4). The variance Julian date $(J D)$ is a surrogate for the temporal pattern in smolt outmigration over the season. 
Table 4. Hierarchical regression for spill efficiency (SE), testing the significance of $F_{S P}$ and $P_{S P}$ after accounting for significant environmental covariates.

\begin{tabular}{lrrllcc}
\hline \multicolumn{1}{c}{ Source } & DF & \multicolumn{1}{c}{ SS } & \multicolumn{1}{c}{ MS } & $F$ & $P$ & $r^{2}$ \\
\hline Total $_{\text {COR }}$ & 258 & 80588.50 & & & & \\
Env. covariates* & 2 & 44772.33 & 22386.165 & $F_{2,256}=160.01$ & $\approx 0$ & 0.556 \\
$\quad$ Error & 256 & 35816.17 & 139.906914 & & & \\
$F_{S P}$ & 1 & 7.60 & 7.6 & $F_{1,255}=0.05$ & 0.82 & 0.556 \\
$\quad$ Error & 255 & 35808.57 & 140.425765 & & & \\
$P_{S P}$ & 1 & 4052.72 & 4052.72 & $F_{1,255}=32.54$ & $\approx 0$ & 0.606 \\
$\quad$ Error & 255 & 31763.45 & 124.56 & & &
\end{tabular}

* Environmental covariates entered into model: temperature and JD.

\section{Spill Effectiveness (SN)}

The same four environmental covariates and two spill covariates used in Sections 2.1 and 2.2 were again used to investigate the modeling of spill effectiveness.

\section{Stepwise Regression}

A total of six covariates were found to be significant $(P<0.05)$ in describing the daily variation in spill effectiveness (Table 5). The four environmental covariates that first entered the model were water temperature, Julian date $(J D), J D^{2}$, and forebay elevation. The last two covariates that entered the model were spill volume $\left(F_{S P}\right)$ and spill fraction $\left(P_{S P}\right)$, The overall model had an $r^{2}=0.721$.

Table 5. ANOVA table for sequential stepwise regression model for spill effectiveness $(S N)$.

\begin{tabular}{lrcccc}
\hline \multicolumn{1}{c}{ Source } & DF & SS & MS & $F$ & $P$ \\
\hline Total $_{\text {COR }}$ & 258 & 0.00465173 & & & \\
Temperature & 1 & 0.0000983 & 0.0000983 & $F_{1,257}=5.55$ & 0.019 \\
$\quad$ Error & 257 & 0.0045535 & 0.0000177 & & \\
Julian date & 1 & 0.0005993 & 0.0005993 & $F_{1,256}=38.80$ & $\approx 0$ \\
$\quad$ Error & 256 & 0.0039542 & 0.0000154 & & \\
$\mathrm{JD}^{2}$ & 1 & 0.0001655 & 0.0001655 & $F_{1,255}=11.14$ & 0.001 \\
$\quad$ Error & 255 & 0.0037887 & 0.0000149 & & \\
Forebay elevation & 1 & 0.0001258 & 0.0001258 & $F_{1,254}=8.72$ & 0.003 \\
$\quad$ Error & 254 & 0.0036629 & 0.0000144 & & \\
$F_{S P}$ & 1 & 0.0022539 & 0.0022539 & $F_{1,253}=404.71$ & $\approx 0$ \\
$\quad$ Error & 253 & 0.0014090 & 0.0000056 & & \\
$P_{S P}$ & 1 & 0.0001113 & 0.0001113 & $F_{1,252}=21.6$ & $\approx 0$ \\
$\quad$ Error & 252 & 0.0012977 & 0.0000051 & & \\
\hline
\end{tabular}




\section{Hierarchical Regression}

The best-fit models used $\ln S N$ as the dependent variable. The four environmental covariates that entered the stepwise regression model of Section 2.3.1 had an $r^{2}=0.574$. Both spill fraction $(P \approx 0)$ and spill volume $(P \approx 0)$ significantly improved the fit of the model when entered after the environmental covariates. Spill fraction $\left(P_{S P}\right)$ entered the model as a linear effect and increased the $r^{2}$ to 0.686 (Table 6). Spill volume $\left(F_{S P}\right)$ entered the model as a quadratic effect and increase the $r^{2}$ to 0.766 (Table 6). Considering just the spill covariates, spill effectiveness can be modeled as a function of spill fraction $\left(P_{S P}\right)$ where

while the spill volume model is

$$
S N=e^{3.191-0.644 P_{S P}}
$$

$$
S N=e^{5.827-0.0106 F_{S P}+0.000022 F_{S P}^{2}}
$$

for average environmental conditions during midseason. Figure 1 shows the residual plot for the spill effectiveness model as a function of environmental covariates and spill volume. Figure 2 shows the corresponding quantile-quantile (q-q) plot used to visually inspect for normality of the residuals. Corresponding residual and q-q plots for the model as a function of spill fraction are similar in appearance and not repeated here.

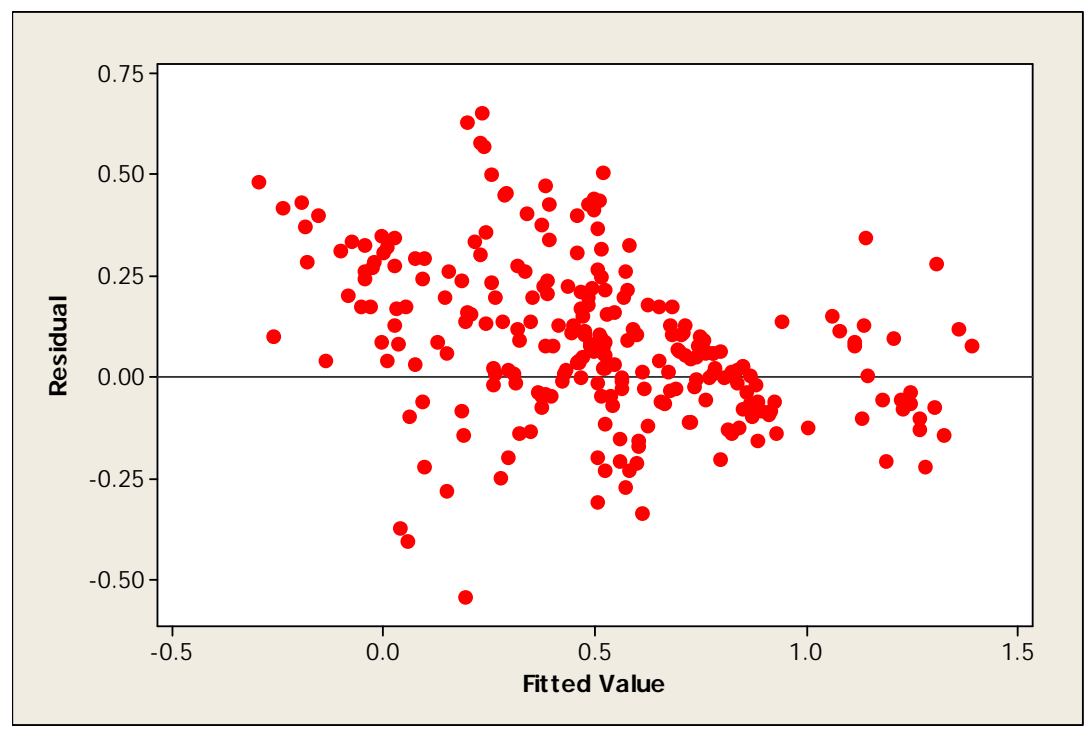

Figure 1. Residual plot for the regression model having response variable $\ln (S N)$ and independent variables: environmental covariates*, $F_{S P}$, and $F_{S P}^{2}$. Environmental covariates entered into model: $\mathrm{JD} \mathrm{JD}^{2}$, temperature, and forebay elevation. 


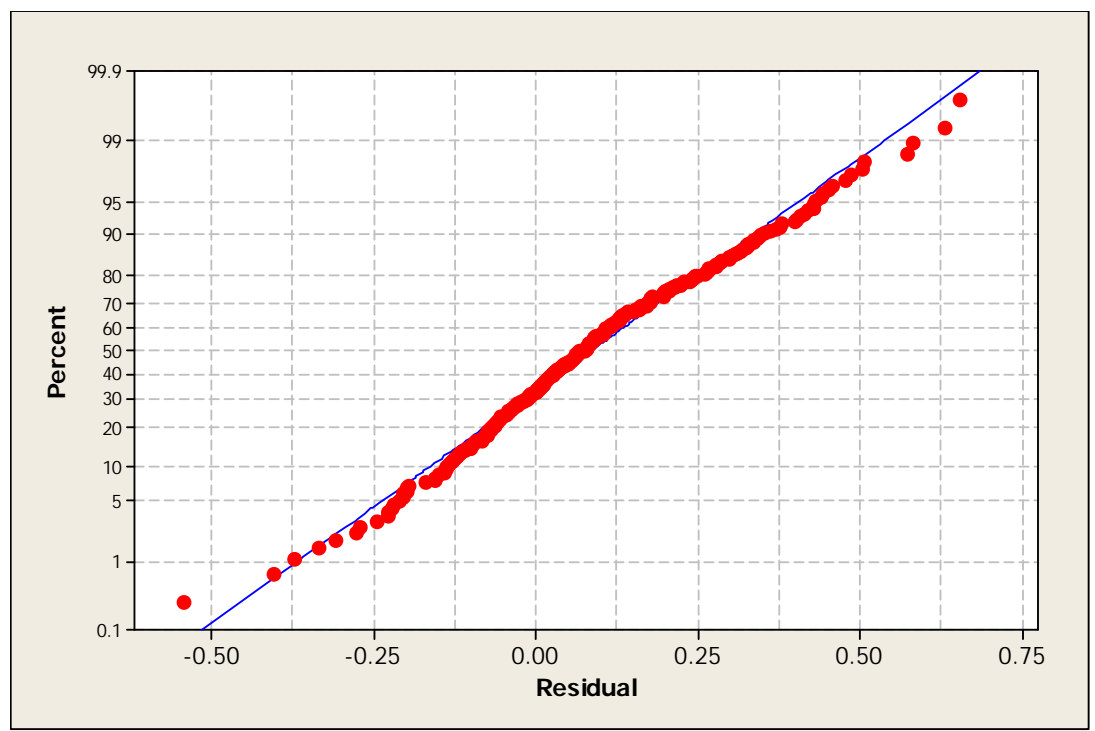

Figure 2. Normal probability plot of residuals for the regression model having response variable $\ln (S N)$ and independent variables: environmental covariates*, $F_{S P}$, and $F_{S P}^{2}$.

* Environmental covariates entered into model: JD, $\mathrm{JD}^{2}$, temperature, and forebay elevation.

Table 6. Hierarchical regression for natural log-transformed spill effectiveness $(S N)$, testing the significance of $F_{S P}, F_{S P}^{2}$, and $P_{S P}$ after accounting for significant environmental covariates. (Two outlying points were omitted from the analysis.)

\begin{tabular}{|c|c|c|c|c|c|c|}
\hline Source & $\mathrm{DF}$ & SS & MS & $F$ & $P$ & $r^{2}$ \\
\hline Total $_{\mathrm{COR}}$ & 256 & 861,334 & & & & \\
\hline Env. Covariates* & 4 & 494,674 & 123,668 & $F_{4,252}=85.00$ & $\approx 0$ & 0.574 \\
\hline Error & 252 & 366,660 & 1,455 & & & \\
\hline$F_{S P}, F_{S P}^{2}$ & 2 & 165,008 & 82,504 & $F_{1,250}=102.35$ & $\approx 0$ & 0.766 \\
\hline Error & 250 & 201,653 & 806.12 & & & \\
\hline$P_{S P}$ & 1 & 96,035 & 96,035 & $F_{1,251}=89.07$ & $\approx 0$ & 0.686 \\
\hline Error & 251 & 270,625 & 1,078 & & & \\
\hline
\end{tabular}

* Environmental covariates entered into model: JD, $\mathrm{JD}^{2}$, temperature, and forebay elevation. 


\section{Conclusions}

The results of the six regression analyses suggest the following:

1. For spill passage abundance, while spill fraction $\left(P_{S P}\right)$ has a significant effect $(P=0.0023)$ beyond environmental covariates, it does little to increase the overall model $r^{2}$ (i.e., from 0.385 to 0.407 ). Spill fraction is statistically but not biologically significant in explaining spill passage abundance.

2. For spill efficiency, spill fraction $\left(P_{S P}\right)$ significantly $(P \approx 0)$ improves model fit after consideration of environmental covariates. However, it improves model explanation of the daily variation in spill efficiency from $r^{2}=0.556$ to 0.606 . Again, spill fraction is statistically but probably not biologically significant in explaining daily fluctuations in spill efficiency.

3. For spill effectiveness $(S N)$, both spill fraction $\left(P_{S P}\right)$ and spill volume $\left(F_{S P}\right)$ significantly $(P \approx 0)$ help describe daily variation. In both cases, overall model $r^{2}$ increased by over 0.48 points when these variables were added to a model with just environmental covariates.

Hence, spill fraction and spill volume have a much more influential effect on spill effectiveness than either spill passage abundance or spill efficiency.

In interpreting the result of this preliminary analysis, it must be recalled that the data used were observational and opportunistic in nature. In order to observe a wide breadth in spill effectiveness $(S N)$ values, multiple years of data had to be pooled. In some instances, annual ranges in response did not even overlap, thus precluding the effective use of year indicators as covariates. The models generated for spill effectiveness [Eqs. (1) and (2)] should therefore be treated as preliminary models or working hypotheses that should be formally tested using a randomized, replicated, manipulative investigation.

\section{Literature Cited}

Draper, N.R., and Smith, H. 1998. Applied regression analysis. Wiley \& Sons, New York, New York, USA.

Kutner, M.H., Nachtsheim, C.J., and Neter, J. 2004. Applied linear regression models. McGrawHill/Irwin, New York, NY, USA. 
